
<smiles>C#CCC(C)C</smiles>

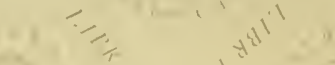
7,1 wil $=$

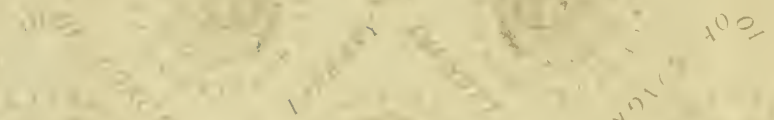

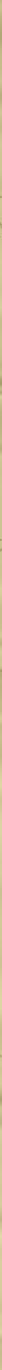




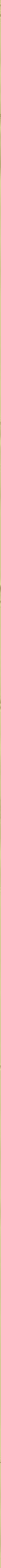






\section{SWINE HUSBANDRY.}

A Practical Manual for the Breeding, Rearing and Management of Swine,

WITI

SUGGESTIONS AS TO THE PREVENTION AND TREATMENT OF THEIR DISEASES.

By F. D. COBURN.

NEW, REVISED AND ENLARGED EDITION.

ILLUSTRATED

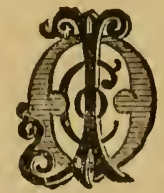

New York:

Orange Judd Rompanv. 
$S F 395$

$\mathrm{C}_{66}$

Copruats, 182 .

ORANGE JUDD TOMPANT

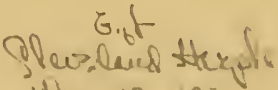

4hey $17,19 \% 2$

Printed in U. S. A. 


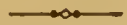

CHAPTER I.

.ntroductory

CHAPTER II.

Value of the Ilog Produet.

IREEISS OF SWINE, THEIR CHARACTERISTICS AND WORTH.

CHAPTER III.

The Poland-Chinas 21

CHIAPTER IV.

The Chester Whites. 34

CHAPTER V.

The Berkshires 42

CHAPTER VI.

The Suffolks. 54

CHAPTER VII.

The Fisex 62

CHAPTER VIII.

The Yorkshires.-Cheshires, or Jefferson County 8 wine, of New York. -Lancashircs.-Victorias.-Neapolitan8._Jersey Red8._Durocs. 69 CHAPTER IX.

Relative Merits of the Suffolk, Essex, and Berkshire. By E. W. Cottrell

\section{RAISING AND FATTENING SWINE.}

CHAPTER X.

The Boar-How to Choose and How to Keep Ilim. 89

CHAPTER XI.

The Sorv and Her Pigs 95

CHAPTER XII.

Castrating and Spaying. 105

CHAPTER XIII.

Pasture and Summer Food. $-108$

CIIAPTER XIV.

Fattening .118

CHAPTER XV.

Cooking Food for $\$$ wine-Food Cookers. 
CHAPTER $\mathrm{X}$ VI.

Hog Houses and Pens

CHAPTER XVII.

Slaughtering, Curing, and Preserving

CHAPTER XVIII.

Hog-Feeding and Pork Making 156

\section{CIIAPTER XIX.}

The Effects of Cold Weather on Fattening Swine.-Experiments made at the Kansas State Agricultural Collcge Farm, by E. M. Shelton,

Professor of Agriculture

CHAPTER $\mathrm{XX}$.

Feeding for Fat and Lean.

\section{CHAP'TER XXI.}

The Gradual Disappearance of White Swine from American Farms _ 207

\section{CHAPTER XXII.}

Scme General Observations.-Rooting and its Prerention.--Ear Mutilation and Ear Marks.-Sows Eating their Pigs.-Q'uarrelsome and Fighting Hogrs.-Condition of Sows for Breeding.--Is it Profitable to Cure Pork ?-Reports of Remarkable Growth.-Prize Animals for Brecding.-Fecding Cooked Wheat.-Hogging-off Corn Fields.-Felation between the Prices of Corn and Pork.Records and Recording.-Standards of Excellence and Scale of Points.-Cost of Pig and Pork.-Stock Yards Receipts. . . . . . . . 213

DISEASES OF SWINE, PRACTICAL INFORMATION AS TO THEIR CAUSES, SYMPTONS, PREVENTION, AND CURE.

CHAPTER XXIII.

Diseases of Swine and Their Treatment.-Introductory.-Anthrax Diseases or "Hog Cholera." ..... . . . . . . . . . . . . . . . . . . . 239

CHAPTER XXIV.

The So-called "IIog Cholera." By Doct. H. J. Detmars ... . . . . . . 253 CHAPTER XXV.

The So-called "Ilog Cholera." $2 \div 3$

\section{CHAPTER XXVI.}

Various Diseases Common to Swine.-Worms.-Wrichina spiralis.Kidney Worms.-Measles.- Mange.-Lice.-Common Cough.Pneumonia.-Quinsy or Strangles.-Nasal Catarrh.-Inflammation of the Brain, Epilepsy or "Blind Staggers."-Apoplexy.Paroplegia. - Diarluna or Scours.-Constipation.-Eversion of

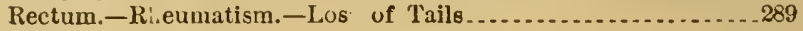




\section{PREFACE TO THE THIRD REVISED AND ENLARGED EDITION.}

ONCE more has come from its publishers a reminder that the most recent edition of Swine Husbandry has all been sold, and the request that some intended revision shall be speedily prepared, with a view to early supplying the demand which has been continnous since the work was first announced.

With an aim to having it as nearly as may be abreast of the times, various changes have been introduced, and additions made for this issue of facts which were only recently available. The figures in the introductory chapter have been brought down to the latest dates possible. 'The chapter (somewhat amplified in this edition) of experiments by Prof. E. M. Shelton, at the Kansas State Agricultural College, on "'The Effects of Cold upon Fittening Swine," and that by Prof. W. A. Henry, of the II isconsin Experiment Station, on "Feeding for Fat and Lean," will be found not only especially interesting and instructive, but also the most suggestive recent additions to swine literature. For their arrange. ment and careful revision especially for this rolume, griteful acknowledgment is hereby made. To Mr. Charles B. Mrurray, editor of the Cincinnati Price Current, Hon. L. N. Bonham, and secretaries of the various swine breeders' associations, the anthor is also indebted for very valuable data furnished.

F. D. Coburn.

Kansas City, Kansas, 1897. 


\section{PREFACE TO FIRST EDITION.}

In preparing this work, I have acted upon the belief that no one man, or any half-dozen men, know all there is worth knowing on a subject so extensive and important as that of Swine Husbandry; still, there are many men who know something concerning some branch of it, which they hare learned by long experience, careful study, and close observation, and who hare acquired their knowledge under precisely such conditions and circumstances as today surround many other men, who have neither experience nor sound advice to guide them.

It has been less my object to make an original book, filled with fine theorics, and the linited experiences of one individual, than to condense in one small volume, from all available sources, the conclusions and ideas of the most practical, successful, observant men who have followed the business in our own time, and in our own country, leaving the reader free to form his own conclusions, and pursue such methods as shall, with the light before him, seem most rational and profitable.

As to the choice of breeds of swine, I have my prerer(c) 
ences, which will be found freely expressed elsewhere, but I can fully appreciate the fact, that a breed exactly suited to the wants of farmers in one locality, might not meet the needs of those in other portions of the country, who make pork for different purposes, and under widely different circumstances, and for different markets.

So long as mankind differ about so many other matters, it is idle to expect them to agree upon any one breed of swine, or upon onc manner of breeding and feeding as being altogether the best.

Each breed has its champions, and each, in proper hands, under favorable circumstances, with congenial food and climate, has proven itself entirely satisfactory; while animals of the sane breed, but with different treatment and surroundings, would have been found in every way unsatisfactory, and discarded for what their owner considered positive knowledge of their worthlessness.

I am confident that each of the leading breeds has its place and its merits, and for this reason I have not undertaken to exalt any one of them over another. One person, by a lucky purchase of animals of a certain breed, and by proper management, attains unusual success, and from that time is satisfied in his own mind, that he possesses a breed incomparably better than any other; at the same time, some other person, with a breed of entirely different characteristics, has been even more successful, and knows, at least to his own satisfaction, that he possesses the one breed worth having, and cares not to be told that some other may also be valuable.

If this book shall serve to encourage the keeping of better swine, in a better, more rational, and consequently 
more protitable way, my labors will not have been in vain.

'To the many correspondents, heveders, and friends. who proffered assistance and eneomragement, and to the numerous journals I have quoted-which I have simed to duly credit-1 am moler lastingr obligations, and any sueeres this affort attatius will be latrecty due to them.

From the Hon. John .I. Millikin (present State 'l'reasurere of (Ohio), csperially, much valualle information has bern obtaind.

H. 1). (Comblis.

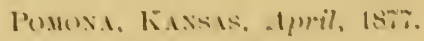




\section{SWINE HUSBANDRY.}

\section{CHAP'TER I.}

\section{INTHOHCGTORY "IO TILE IEVISEI) LDITION- SOME STATISTIES.}

The United States Secretary of Agriculture, in his Anmual Report, estimaterl the number of hogs in the

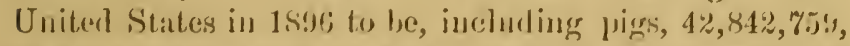
of an atverage value of 84.35 cach, of at total value of

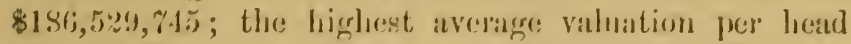
being in Rhorle fstind, \$9.80, and the lowest, in Florida, 8\%.16. Of the total mumber, there were, in the fourteen States that may porperly be designated as the Mississippi valley, vi\%, Wisconsin, Illinsis, Indiana, Ohio, Kentucky, 'I'runcssse, Mississippi, Minnesota, Jowa, Nebraska, Missouri, Kansil, Arkansas and Lonisiana,

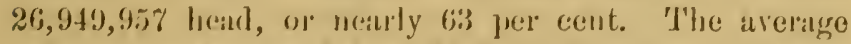
value per liearl ranged from \$15.27 in Wisconsin, to \$\$.53 in Arkansas, the total value being $\$ 119,156,111$. In the same report, the corm crop in the United States for the year 1895 is figured at $2,151,138,580$ ) bushels, worth $\$ 544,98 \pi, 534$, of which the fonrtecn Mississippi Valley Stales mentioned above produced 1,691,408,77\% bushels, the farm valnation of which, counted at $\% \% . \%$ cents per bushel, or $\$ 375,31 ; 9,5159$, represented $78.6 \%$ of the total corn erop, and fig per cent of its value for the entire Union.

It is no doubt safe to say that few persons have any proper conception of the immensity of the swine-producing interest in the United States, or are aware that nearly one-half in numbers and more than one-loalf in 
Falue of all the swine in the world, are reared and fattened in this country. The distribution of the world's supply, according to the most recent available returns, is shown in the table below, which gives the number in the United States in 1896, in tho United Kingdom in 1896, British North American Provinces in 1894, and in other comntries having 100,000 or more somewhat earlier :

Unlted stales............2, 842,759

Russia ................ 9, 24,2,447

(iteI)

Allstro-Hungary . . . . . . . . . \$,3ix3,338

France........ ... . . . . . . 5, 560,952

sp:tin.................. $+3,3,2,000$

Unlted Kingdom............, $, 8,8,801$

Switzerlamd............. 5ki5, ה1

$1 t n 1 y \ldots \ldots \ldots \ldots \ldots \ldots \ldots \ldots \ldots .1,800,(00 i)$

K. $\mathbf{X}$. A. Provinces........ 1, $\left.7(1) 2,7 x_{5}\right)$

Rommani:............. 20.124

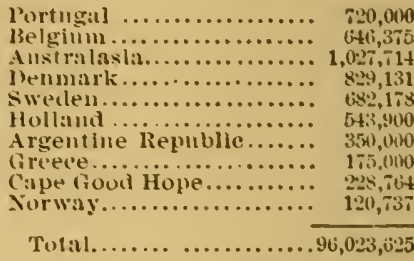

50,000 839,131 i8:2, 173 $4: 3,900$ $35 x, 000$ $175,(110)$ $2.8,664$ 120,737

Tol:11. $96,0: 23,6225$

The gradual rariation in the number of swine in the United States during the twenty-five years prior to and inclubing 1896, is well shown in the following fignres. 'These are the estimates by the United States Department of Agriculture, of the mumber in Jamuly of each year:

\begin{tabular}{|c|c|c|}
\hline 872. & $36,2=27,603$ & $18 \times 4$ \\
\hline $.32,632,6(3)$ & $\ldots+4,1 \div 2,200$ & $.51,(0)=.7 \times 0$ \\
\hline $.310,560,90101$ & $.43,270,080$ & $1,625,1106$ \\
\hline $.28,062,2001$ & $\ldots+4,2(k), 813$ & $.52,0348,019$ \\
\hline $25, \therefore 26,8(0)$ & $45,142,657$ & $41,004, \times 107$ \\
\hline$C, 1(x)$ & $.+6,(6), 2,043$ & $45,2(4,4) 8$ \\
\hline $.32,262=, 5(14)$ & $.41,61: 3,36$ & $.44,165,716$ \\
\hline ..34.766,.200 & $1588 \ldots \ldots \ldots \ldots+4,346,505$ & $\ldots+2,54:, 759$ \\
\hline$\ldots 34,0 ; 34,1(1)$ & & \\
\hline
\end{tabular}

Mr. Charles B. Murray, editor of the Cincinnati Price Current, who is the most prominent authority on figures pertaining to the subject, estimates the nmmber of hogs packed in the United States in the twelve months ending March 1, 1593, 1594, 1895 and 1896, as shown below :

\begin{tabular}{|c|c|c|c|c|}
\hline & $1345-84$. & $1384-95$. & $1593-54$. & $1542-93$ \\
\hline$\overline{\mathrm{Pa}}$ & 15,010 & 16,0 & 11,6 & 12,39 \\
\hline & & & & 1,78 \\
\hline & & & & \\
\hline & & & & \\
\hline & & & & \\
\hline & 867 &, 51 & 2,45 & -9 \\
\hline Total & $20,+\$ 80,000$ & $21.619,000$ & $16,789,000$ & $18,196,0$ \\
\hline
\end{tabular}


These figures represent only the organized pork packing of the country, done in cities; and to obtain the aggregate number slaughtered, there should be added those killed by farmers for home consumption and limited neighborhood sale, in weight about two-thirds as much more, and in numbers a somewhat larger proportion.

The exports of live hogs from the United States to foreign countries are reported by the National Bureau of Statistics, for each of the twenty-five years uamed below (ending June 30th), as follows :

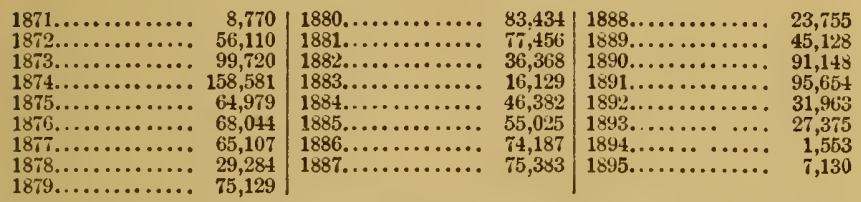

The exports of bacon (including sides, hams and shoulders), pork and lard, to foreign countries, as officially reported by the Statistical Burean, for each of the twenty-five years ending June 30 , were:

\begin{tabular}{|c|c|c|c|c|c|}
\hline & Bacon, lbs. & Pork, lbs. & Lard, lbs. & $\begin{array}{l}\text { A verageEx- } \\
\text { port Value, } \\
\text { cts. per Ib. }\end{array}$ & Tu \\
\hline $18 \pi 1$ & $71,446,85 t$ & $39,250,750$ & $80,037,297$ & 12.05 & $\$ 222,992,023$ \\
\hline 1872 & $2+6,208,143$ & $57,169,518$ & $199,651,660$ & 8.99 & $45,426,519$ \\
\hline 1873 & $395,381,737$ & $64,147,+61$ & $230,534,207$ & 8.88 & $61,274,987$ \\
\hline 1874 & $34 \tau, 405,405$ & $70,482,379$ & $205,527,471$ & 9.33 & $58,500,639$ \\
\hline 1875 & $250,286,549$ & $56,152,331$ & $166,869,393$ & 12.08 & $5 \pi, 184,630$ \\
\hline 1876 & $327,730,172$ & $54,195,118$ & $168,405,839$ & 12.32 & c7 $7,837,963$ \\
\hline $18 \div 7$ & $460,057,1+6$ & $69,671,894$ & $234, \pi 41,233$ & 10.64 & $81,371,491$ \\
\hline .875 & $592,814,351$ & $71,889,255$ & $342,766,254$ & 8.60 & $86,687,858$ \\
\hline 1879 & $732,249,576$ & $84,401,670$ & $326,658,686$ & 6.90 & $78,738,674$ \\
\hline 1880 & $759,773,109$ & $95,949,780$ & $374,979,286$ & 6.89 & $84,838,242$ \\
\hline 1881 & $746,914,545$ & $107,928.080$ & $378,142,496$ & 8.49 & $104,660,065$ \\
\hline $188^{2}$ & $468,026,640$ & $80,447,466$ & $250,367.740$ & 10.37 & $82,852,940$ \\
\hline 1883 & $340,258,670$ & 62,11 & $224,718,474$ & 11.32 & $70,966,268$ \\
\hline 1884 & $389,499,368$ & $60,363,313$ & $265,094,719$ & 9.75 & $69,740,456$ \\
\hline 1885 & $400,127,119$ & 72.0 & $283,216,339$ & 8.59 & $64,883,110$ \\
\hline 1886 & $419,788,796$ & $87,267,715$ & $293,728,019$ & 7.13 & $57,125,408$ \\
\hline 1887 & $419,922,955$ & 85,8 & $321,533,746$ & 7.45 & $61,658,685$ \\
\hline 1888 & $375,439,683$ & $58,900,153$ & $297, \pi 40,00 \tau$ & 8.10 & $59,299,85^{*}$ \\
\hline 1889 & $400,224,646$ & $64,133,639$ & $318,242.990$ & 8.52 & $66,716,097$ \\
\hline 1890 & $608,490,956$ & $80,068,331$ & $471,083,598$ & 7.35 & $85,281,174$ \\
\hline 1891 & $599,085,665$ & $82,136,239$ & $498,343,927$ & 7.19 & $84,908,698$ \\
\hline 1892 & $584,776,389$ & $80,714,227$ & $460,045,776$ & 7.56 & $85,116,566$ \\
\hline 1893 & $473,936,329$ & $53,372,366$ & $365,693,501$ & 9.46 & $84,554,822$ \\
\hline 1894 & $503,628,148$ & $64,744,528$ & $447,566,867$ & 9.19 & $93,433,5 \times 2$ \\
\hline 1895 & $558,044,099$ & $58,266,893$ & $474,895,274$ & 8.22 & $89,696,768$ \\
\hline
\end{tabular}




\section{The quantity and ralne of lard oil exported in the} twenty-five yeurs subsequent to and including $18 \% 1$, euding June 30, is stated as follows:

\begin{tabular}{|c|c|c|c|c|c|c|c|}
\hline Year. & Gallous. & Vialue. & $\left|\begin{array}{c}\text { Value } \\
\text { per gal. }\end{array}\right|$ & Year. & Gallons. & Value. & $\begin{array}{l}\text { Value } \\
\text { per gal, }\end{array}$ \\
\hline 1ร.1 & $14, \times 02$ & $153,8 \bar{x})$ & 104.09 & 10सt & $71: 2,6.10$ & 504.218 & 70.75 \\
\hline $1 N^{2}: 2$ & & & 81.12 & 1625 & $6.15 i$ & & 60.63 \\
\hline 153 & & & 76.31 & & (973.2:기 & & 51.35 \\
\hline 1 sit & 252.5 & 203. & 80.50 & 1 TSE & 975.113 & 19,274 & 53.25 \\
\hline $1 \leqslant 75$ & & & 100.54 & liss & & 09,514 & 54.73 \\
\hline 187 & 1 & 1 & 161.93 & $1:$ & 113 & !) & 63.03 \\
\hline $187 i$ & & & & $18(40$ & 1,2 & 43 & 54.61 \\
\hline 18.8 & 1.651 & (M) & 60.2 & 1891 & 1,0 & 186 & 51.53 \\
\hline 1874 & & $1,0 \mathrm{~s}$ & & $180 \%$ & & 1 & 55.08 \\
\hline $1 \leqslant 0$ & $1.50 \%, 54)$ & $816,+4 i$ & 54.15 & 1893 & & 346.613 & 69.14 \\
\hline 15 & & & tit & $1 \times 14$ & & 49 , & 66.00 \\
\hline $15 \times ?$ & 5016,254 & & 85.7 & 1595 & $553,+21$ & 304,093 & 55.00 \\
\hline $1 \times 83$ & $379, \cdots 15$ & 353,184 & 93.14 & & & & \\
\hline
\end{tabular}

The following table shows the distribution of American hog products by cxportation to the prineipal purchasing comities, and the quantities taken by each, and their value, during the year ending June 30, 1895:

\begin{tabular}{|c|c|c|c|}
\hline Countriets. & * Bacoll, los. & l'urk, llos. & Latrd, Ibs. \\
\hline United kingrom......... & $436,010,562$ & $14,2618,8622$ & $154,251,911$ \\
\hline Ftitule $\ldots . . . . . . . . . . .$. & $9 \leq 42,045$ & 236,600 & $34,665,860$ \\
\hline Germany................... & $15,13 i, \$ ! 13$ & $2.1+4, \times 50$ & $104,121,137$ \\
\hline 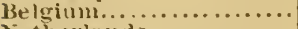 & $410,0210,91,33$ & $225,(1100$ & $38,163,0335$ \\
\hline Netherlands ........ & $9.631 .19 \%$ & $4: 1,232$ & $25,451 i, 561$ \\
\hline Denmark. & 458.119 & & $6.952 .46 i$ \\
\hline Sweden and Norway.... & $2.61 \times, 2 x^{4}$ & 167,490 & $3,35 \overline{7}, 535$ \\
\hline 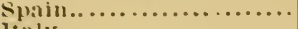 & (i0,, 316 & $\cdots \cdots \cdots$ & 70.134 \\
\hline 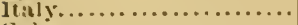 & 00.915 & & (525, 250 \\
\hline Cubil ..................... & $9,0(1 ;, 5 ; 29$ & $f(2,0,100$ & $30,(6-2,2,512$ \\
\hline Hayti..................... & 332,1132 & 13.507 .650 & $3,267,0090$ \\
\hline l'urto Rieu................ & 1.079 .633 & $3,-28,5,-20101$ & $3,414,798$ \\
\hline Brilish West Indies...... & 596,378 & $7.4+19.033$ & $2,430,4 \$ 3$ \\
\hline Mexico................. & 297.599 & 2.14 is & $1,908,070$ \\
\hline 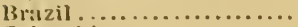 & $22.55 \div, 58 \div 2$ & $1,1: 23,292$ & $12,556,491$ \\
\hline Columbia .................. & 98,902 & 83,314 & $1,2) 2 x, 235$ \\
\hline Venezuela ................ & $(8 \times 0,551$ & 25,200 & $6,754.790$ \\
\hline British Gulana........... & 363,803 & $2.685,190$ & 395,347 \\
\hline Perm. . . . . . . . $\ldots \ldots \ldots \ldots$ & $18,316 \mathrm{i}$ & 15,100 & $8 !, \times 51$ \\
\hline Quelres, Ont., ete.t....... & $7,124, f 26$ & 4.757 .080 & $2,139, \pi \pm 0$ \\
\hline Nurn scotia, etc.......... & 66,798 & $1,218,443$ & 71.112 \\
\hline Newfommdlatud, ele....... & 203,223 & $2,01210,340$ & 187.1181 \\
\hline All otlier..................... & $1,825,490$ & $3,54 !,(949$ & $8,+15,00 s$ \\
\hline Total ............... & 555.044 .049 & 58,2 thi, st3 & $474.345,2 \pi 4$ \\
\hline Value. ............... & $S 45,736,560$ & $\$ 4,138,4(10)$ & $836,8=1,5116$ \\
\hline
\end{tabular}

* Includes sides, hams and shoulders.

† Inclucles Mamitoba, Nurtluwest Territorles and Britlsh Columbia.

Below is seen the total number of hogs packed in the West during winter seasons, and cost of hogs per one 
hundred pounds gross, for fifty years, according to Cincinnati Price Current special reports:

\begin{tabular}{|c|c|c|c|c|c|}
\hline Season. & No. & Cost. & Seasoll. & No. & Cost. \\
\hline $1895-96 \ldots$ & $(i, 815,800$ & $\$ 3.68$ & $1869-70$. & 2,$6 ; 35,312$ & $\$ 9.22$ \\
\hline $1894-95 \ldots$ & $7,191,520$ & 4.28 & $18 t i 8-t 9 .$. & $2,499,87.3$ & 8.18 \\
\hline $1893-94 \ldots$. & $4,884,082$ & 5.26 & $1867-68 \ldots \ldots$ & $2,781,0 \times 4$ & 6.36 \\
\hline $1892-93 \ldots$ & $4,633,520$ & 6.54 & $1866-67 \ldots \ldots \ldots$ & $2,490,791$ & 5.78 \\
\hline $1891-92 . \ldots$. & $7,761,216$ & 3.91 & $1865-66 \ldots \ldots \ldots$ & $1,-85,955$ & 9.34 \\
\hline $890-91 \ldots \ldots \ldots$ & $8,173,126$ & 3.54 & $1864-65 \ldots \ldots \ldots$ & $2,422,7,9$ & 11.46 \\
\hline $1889-90 \ldots \ldots$ & $6,663,802$ & 3.66 & $186 i 3-64 \ldots \ldots \ldots$ & $3,261,105$ & 5.36 \\
\hline $1888-89 \ldots \ldots \ldots$ & $5,483,852$ & 4.99 & $1862-63 \ldots \ldots \ldots$ & $4,(0), 99,5 \div 0$ & 3.36 \\
\hline $1887-88 \ldots$ & $5,921,181$ & 5.04 & $1861-62 \ldots \ldots \ldots$ & $2,893,66 i ;$ & 2.42 \\
\hline $18 \times 6-87 .$. & $6,439,009$ & 4.19 & $1860-61 \ldots \ldots \ldots$ & $2,155,702$ & 4.57 \\
\hline $1885-86 \ldots .$. & $6,298,9,95$ & 3.66 & $1859-10 \ldots \ldots$ & $2,350,822$ & 4.73 \\
\hline $188+-85 .$. & $(i, 460,240$ & 4.29 & $1858-59 \ldots$ & $2,465,5,5,52$ & 5.02 \\
\hline $1883-84$. & $5,402,06 t$ & 5.18 & $1857-58 \ldots \ldots$ & $2,210,778$ & 3.89 \\
\hline $2-83$ & $6,132,212$ & 6.28 & $185 f j-57 \quad \ldots$ & $1,818,468$ & 4.75 \\
\hline $1-82$. & $5,747,760$ & 6.06 & $1855-56 \ldots \ldots$ & $2,489,502$ & 4.60 \\
\hline $9-81 \ldots$ & $6,919,4$ & 4.tit & $1854-55 \ldots \ldots$ & $2,124,404$ & 3.37 \\
\hline$-80 \ldots$ & 6,950 & 4.18 & $1853-54 \ldots \ldots$ & $2,534,770$ & 3.35 \\
\hline-79. & 7 & 2.85 & $1852-53 \ldots \ldots \ldots$ &, 110 & 4.81 \\
\hline$-78 .$. & $6,505,44$ & 3.99 & $1851-52 \ldots \ldots \ldots$ & $1,182,8 \div 6$ & 3.56 \\
\hline $7-77$. & $5,101,308$ & 5.74 & $-51 \ldots$ & $1,332, \times 6,7$ & 3.00 \\
\hline $5-76 \ldots$ & $4,880,135$ & 7.05 & $50 .$. & $1,652,2: 20$ & 2.13 \\
\hline $1874.75 \ldots$ & $5,566,226$ & 6.66 & $-49 \ldots$ & $1,560,000$ & 3.75 \\
\hline $1873-74 .$. & $5,466,200$ & 4.34 & $1847-48 \ldots$. & $1,710,000$ & 2.60 \\
\hline $1872-73 \ldots \ldots$ & $5,410,314$ & 3.73 & $1846-47 \ldots$ & 800,000 & 2.85 \\
\hline $1871-72 \ldots$ & $4,831,5,58$ & 4.12 & $1845-4 C \ldots \ldots \ldots$ & 900,000 & 3.90 \\
\hline $1870-71 \ldots \ldots \ldots$ & $3,695,251$ & 5.26 & ................ & $\ldots \ldots \ldots$ & ... \\
\hline
\end{tabular}

'The following table indicates the average gross weights of hogs paeked in the West during winter seasons for fifteen years, the average pounds of lard yielded per hog, and their cost per one hundred pounds alive.

\begin{tabular}{|c|c|c|c|}
\hline Season. & $\begin{array}{c}\text { Gross Weight, } \\
\text { per loog. }\end{array}$ & $\begin{array}{l}\text { Lbs. of Lard, } \\
\text { all kinds. }\end{array}$ & $\begin{array}{l}\text { Cost Alive, } \\
\text { per } 100 \text { lbs. }\end{array}$ \\
\hline $1895-96 \hat{b} . \ldots$ & 240.71 & 35.53 & $\$ 3.68$ \\
\hline $189 t-95 \ldots \ldots \ldots \ldots \ldots \ldots \ldots$ & 232.73 & 33.62 & 4.28 \\
\hline $1893-94 \ldots \ldots \ldots \ldots \ldots \ldots \ldots$ & 248.20 & 36.07 & 5.26 \\
\hline $1802-93 . \ldots \ldots \ldots \ldots \ldots \ldots \ldots$ & 227.73 & 31.66 & 6.54 \\
\hline $1891-92 \ldots \ldots \ldots \ldots \ldots \ldots \ldots$ & 247.64 & 34.69 & 3.91 \\
\hline $1890-91 . \ldots \ldots \ldots \ldots \ldots \ldots \ldots$ & 239.75 & 33.45 & 3.54 \\
\hline $1889-90, \ldots \ldots \ldots \ldots \ldots \ldots$ & 250.92 & 36.37 & 3.66 \\
\hline $1888-89 . \ldots \ldots \ldots \ldots \ldots \ldots \ldots$ & 263.46 & 34.76 & 4.99 \\
\hline $188 i-88, \ldots \ldots \ldots \ldots \ldots \ldots \ldots$ & 242.30 & 31.06 & 5.04 \\
\hline $1886-87 \ldots \ldots \ldots \ldots \ldots \ldots \ldots$ & 251.31 & 33.54 & 4.19 \\
\hline $1885-86 \ldots \ldots \ldots \ldots \ldots \ldots \ldots$ & 258.98 & 35.22 & 3.66 \\
\hline $1884-85 \ldots$ & 266.51 & 36.02 & 4.29 \\
\hline $1883-84 \ldots \ldots \ldots \ldots \ldots \ldots \ldots$ & 251.44 & 33.25 & 5.18 \\
\hline $1882-83 \ldots$ & 267.02 & 35.43 & 6.28 \\
\hline $1881-82 \ldots$. & 262.70 & 36.44 & 6.06 \\
\hline
\end{tabular}

The average live weight of hogs, average cost per one hundred pounds live weight, and percentage yield of lard from those packed at the points named, in the winter seasons of $1894-95$ and $1895-96$, is shown as follows: 
SWINE HUSBANDRY.

\begin{tabular}{|c|c|c|c|c|c|c|}
\hline & $\frac{\text { Average }}{1895-96 .}$ & $\frac{\text { Welght. }}{189495 .}$ & $\frac{\text { Cost. }}{18.95-96 .}$ & $\frac{001 \mathrm{bs} .}{1894-95}$ & $\frac{\text { Ling } ~}{1895-6}$ & $\frac{\text { rcent. }}{1834-45}$ \\
\hline Chieago ............. & 248.59 & 246.61 & 83.81 & 54.36 & 15.59 & $152 \mathrm{~s}$ \\
\hline Kansus City.......... & 243.53 & 234.29 & 3.57 & 4.16 & 15.02 & 14.20 \\
\hline Eouth Omalıa........ & 268.25 & 208.95 & 3.55 & 4.13 & $\left.14.6^{\circ}\right)$ & 14.44 \\
\hline S1. Loulis............ & $2 \div 4.73$ & 203.131 & 3.68 & 4.28 & 14.25 & 14.11 \\
\hline Iudiauapolls ........ & 213.60 & 2.25 .97 & 3.62 & 4.34 & 15.42 & 14.76 \\
\hline Cincinnati ........... & 233.46 & 235.57 & 3.71 & 4.35 & 15.65 & $18.5 \pi$ \\
\hline Mllwaukee .......... & 243.91 & 28.20 & $3.6 \%$ & 4.46 & 12.55 & 12.70 \\
\hline r'mialiy ....... & $\because 39.50$ & $2:-4.010$ & 3.65 & 4.35 & 11.48 & 11. (it) \\
\hline Clevelaut ............ & 190.00 & 185.00 & 3.85 & 4.40 & $12 . \% 0$ & $13.3 n$ \\
\hline St. l':ttsl.............. & 22.35 .00 & 230.00 & $3 . t i 5$ & 4.15 & 14.23 & $13.4: 3$ \\
\hline Ceilar Rapids........ & 244.00 & $2: 6.190$ & 3.52 & 4.15 & 13.23 & 13.27 \\
\hline nttumwa............. & 226.00 & 218.00 & 3.50 & 4.15 & 13.27 & 13.30 \\
\hline Louisville... ..... & 242.21 & $2-7.91$ & 3.67 & 4..3!) & 13.70 & 11.8 .1 \\
\hline Sionx City........... & 264.00 & $2 \geq 0,(1) 0$ & $3.4 i$ & 4.15 & 15.15 & 13.tii \\
\hline Delroit ............... & 211.00 & 215.13 & 3.80 & 4.35 & 13.27 & 13.24 \\
\hline St. Ioseph........... & 265.00 & 240.00 & 3.45 & 4.15 & 15.09 & $1 \div .91$ \\
\hline Neluraska City....... & 278.00 & 235.00 & 3.53 & 4.15 & $1: 03$ & 13.38 \\
\hline Ites Moines............ & 256.00 & 222.00 & 3.50 & 4.09 & 15.23 & 14.41 \\
\hline keukuk........... & 235.00 & 215.00 & 3.50 & 4.19 & 14.04 & $13.7^{\circ}$ \\
\hline Lincoln .............. & 249.00 & 215.00 & 3.51 & 4.00 & 13.25 & 11.16 \\
\hline All points........... & 240.71 & 232.73 & 3.68 & 4.28 & 14.16 & 14.4 \\
\hline
\end{tabular}




\section{CHAPTER $r$ 。}

COMPARATIVE VALUE OF THE HOG PRODUCT.

The importance and value to our people of the swine grown in the United States, compared with other kinds of live stock, as shown by official figures, and records that are beyond question, are quite astonishing to those who, for the first time, have them brought to their attention. So long as these animals bring to the coffers of Americans more money than any other single agricultural product, unless it may be wheat or cotton, they are certain to occupy a very high position in the estimation of the producers. Of the money-producing value of swine, as compared with cattle, Hon. John M. Millikin, of Ohio, one of the most experienced and intelligent observers in this direction that our country has ever had, several years ago made some careful estimates, based on anthentic data, that reveal what to many will be a condition of affairs not before suspected. Basing his figures on the United States Census for 1870, he says: "The number of cattle then in the country was $23,820,508$, and of swine $25,703,813$. In the five stock producing States of Kentucky, Ohio, Indiana, Illinois, and Missouri, there were $6,031,819$ cattle, and 10,446,198 swine, the excess of the latter over the former being about or upwards of 70 per cent. In view of the above, from which source do the people of the States named derive the largest amount of money per annum?

"The question cannot be answered with entire accuracy, because there are no certain data by which to determine the number or percentage of each kind of animals sold, or the price realized for each head, and yet the 
result can be closely approximated. Cattle are usually sold at ages varying from three to six years; milch cows and working eattle, which constitute $4: 2$ per cent of the entire number, as above stated, generally attiin an age exceeding six yeurs before they are sold to go out of the conntry. As eattle, including all elisses, have to arrive at an age above three years, it is safe to sily there are not more thin one-fourth the rimmber enumerated sold in each year. With hogs it is quite different. They are shippes off at an average age of about fifteen months, and it is therefore fair to assume that at least four-fifths of the hogs enumerated in $18 \% 0$ were sold within a year from the time of enumerition.

"Upon these data let us make a calculation :

"Upon the hypothesis stated, that one-fourth of the cattle enumerated would be sold during the year, there would be sold 1,50\%,954. Estimating the arerage value of the same as consumed upon the farm, or sold and shipped at $\$ 30$ per head, they would amount to the sum of $\$ 45,238,6: 0$. The total number of logs in the above States being $10,446,198$, four-fifths of which were sold during the rear, would make the number sold $8,356,95 \%$. Estimiting these on the farm, when sold or consumed, at the moderate price of \$s per head, the total ralue is $\$ 66,955,6 \% \cdot$, making the excess receired per annum for hogs, over amount received for cattle, in the fire States named, $\$ 21,71 \%, 052$.

"I am aware that the above showing will be satisfactory to only a few persons, and that it will be sharply eriticised by others. I have made it npon the above data, with a view to seeing what the result wonld be, and not with a riew of depreciating the value and indrantages of raising eattle, nor of unduly exalting the business of raising pork."

At the present time, Chicago is considered the greatest live stock market in the world, and the statisties of the 
live stock trade there, for the year 1873, disclose the startling fact that swine not only brought more money into the pockets of the people than any other description of live stock, but more than all other kinds together, as may be seen by an examination of the following table of actual receipts and actual sales in the open market:

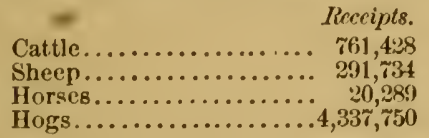

Sales.

\$.35, 264, 26L

$\times 75,000$

$2,028,902$

$53,153,000$

From these figures, it is seen that the value of the hogs marketed there, exceeded that of all other live stock by nearly $\$ 15,000,000$, and this does not include any part of the value of the dressed hogs, litrd, barrelled pork, and eut meats received, the eash value of which amounted to $\$ 8,444,494$, in the same period, making a total value of $\$ 61,59 \%, 494$.

Chicago also boasts of being the leading grain market of the world, and during the same year (18\%3), her trade was a prosperous one, the receipts aggregating $10,000,000$ bushels more than in the previous year, and the estimated value of this vast quantity was $\$ 63,500,000$, scarcely $\$ 2,000,000$ more than thr , alue of the hogs and hog products handled in the same murket in that year.

The value of the hog product exported in 1872 from the United States, exceeded $\$ 45,000,000$, of which England alone took $\$ 22,247,16 \%$, - more than the entire exportation of cattle products for the sime year.

With our fertile, and seemingly inexhaustible soils, both upon the broad prairies and countless creek and river pottoms, the great staple erop is, and ever will be, Indian corn-the grain above all others best adapted to the production of pork; and it is by and through these enormous com crops that we ro and can hold the pork markets of the world at command.

Those who prepare for pork-making with well defined 
plans, and pursue them with system and regularity, keeping none but the best breeds and their crosses, can be quite certain of realizing more satisfactory prices for their corn, taking the seasons together, than by selling it at ruling prices, even at their own doors; while if hauled from home, its cost is increased in proportion to the distance, from five to fifteen cents per bushel.

To illustrate the importance of raising the better grades of hogs, we will use some figures from a circular issued by the "Cincinnati Merchants' Exchange" a few years since, which says: "Whole number of hogs packed during the past scason, at the principal points in the United States, was $4,782,403$; aggregate weight, $1,349,630,955$ pounds, or an average weight of $282^{1} \mid$, pounds. The total amount of money paid for same was $\$ 55,818,711$." - If well bred, well fed, well cared for, and properly fattened, they should have averaged one hundred pounds more per head, adding to the aggregate weight $478,240,300$ pounds, which, at four cents per pound, would have added to the wealth of the producers, in a single year, the snug sum of $\$ 19,129$,612. Truly no insignificant increase of one year's receipts, and on the same basis amounting in twenty years to $\$ 382,592,240-$ money enough to lift the mortgages from the farms of a large number of worthy gentlemen who think that one hog is just as good as another. 


\section{BREEDS OF SWINE}

THEIR CHARACTERISTICS AND WORTH. 



\section{CHAP'IER III.}

\section{THE POLAND-CHINAS.}

Probably no questions have been more frequently propounded to agricultural and live stock journals, than those as to the origin, history and correct name of the large spotted hogs, exceedingly popular in the Western States, and which are ealled, by different breeders, and in different localities, by a great diversity of names. Among the names which bave been given them, are: "Magie." "Butler County," "Warren County," "Miami Valley," "Poland," "Poland and China," "Greas Western," “Shaker," “Union Village," “Dick's Creek," "Gregory's Creek," "Moore," and others ; and inquiries are frequent as to their characteristies, and if all the hogs thus named are not the same breed, which is best? The wranglings and disenssions, by the breeders and friends of the different strains of these hogs, as to their origin, the most suitable and expressire name for the breed, and who should have most credit for efforts to perfect and bring them into popular faror, would, if published, fill volnmes. The following, prepired by Hon. L. N. Bonham, who has for many years been not only a citizen of Butler county, but a breeder of these hogs, and who has made them and their history a long study, was adopted in 1887, by the National Swine Breeders' Association, as the oflicial listory of the breed, and hence it is given here as the accepted version, in lieu of what has before been published on this great and foremost fimily of pork makers :

The Poland-China hog originated in the Miami valley, and it is nowhere apparent that it originated from the purpose or work of any one individual. The conditions of soil, climate, produce, and markets of that region, all favored the business 


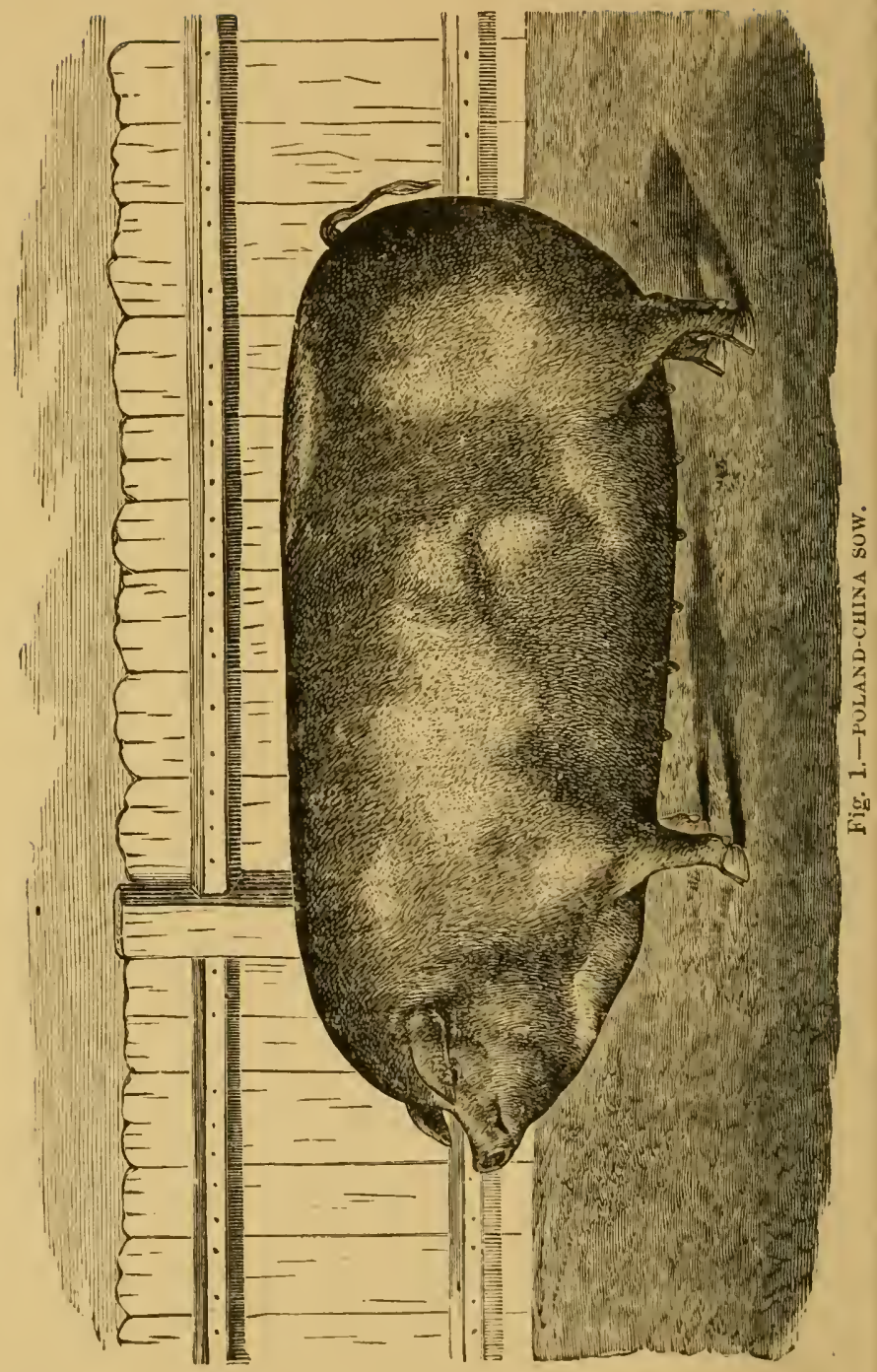


of swine growing, and, as a result, early in the history of Ohio Cincinnati became, for a time, the greatest pork-packing center in the world, and made pork producing the most profitable feature of farming in the surrounding country.

The farmers of Kentucky and Ohio were deeply interested in the common effort to meet the demands of the market, and secure the best possible rewards for their labor and enterprise. Before the advent of improved roads, canals and railways, the concentration of farm products into animals that could be driven to market, induced a general improvement of not only the swine, but the cattle also, of that region. Under the common law of selection, as well as by importation of improved breeds, by the peculiarly favorable conditions of climate, feed and water, by the influence of trarle and fashion, the PolandChina breed of swine originated and leveloped from the common hog of the Miami valley, until it has become the leading breed of the State and many parts of the country.

It is greatly to be regretted that in the earliest history of this breed, we had not, in Ohio and in the West, such facilities for making a record of the work done and means employed by the farmers of the Miami valley, as we now have in the numerous and able stock journals and agricultural papers of this day.

Prior to 1839 there was no paper in the West specially interested in agriculture or live-stock matters. Hence most of the earliest history of the breed, and of swine raising in the West prior to that date, is purely traditional. Happily, however, about the time the interest in pork growing became the leading feature of agriculture in the Miami valley, the Western Farmer was started in Cincinnati, in September, 1839. Its editor, Thomas Affleck, was a man of intelligence and a lover of stock. Associated with him was Charles Foster, who was skillful with his pencil as well as with his pen, and left many well executed cuts and descriptions of animals of southern Ohio and northern Kentucky. The written testimony of these two men may be accepted as the most accurate and valuable of any now available.

The history of the English breeds has been better preserved in the writings of Prof. Low, and earlier English writers. That of the Berkshires is, perhaps, best known of any existing breeds. It is valuable as a help to show how breeds originated. The history of these two best known breeds illustrates forcibly a principle in breeding announced by Prof, Brewer, of New 
Haven. It is this: "A bred of animals is nerer made by crossing two and only two distinet breeds, and preserving the better qualities of hoth. I am not aware," he says, "that there is any such case on record, among all the comntless breeds of our domestic animals. But new breeds are often made of several original breeds by a selection from the mongrel progeny."

The evolution of the Berkshire from the old English hog, the Chinese, the Neapolitan, the Simuese, ilmstrates this principle, though it has oceupied nearly a century of time and study of many indefatigable breelers. Its history is full of interest to all breeders of swine, because it is better molerstood, being more fully recorded in the current writings of this epoch than that of any other breed of swine. Now, as this loreed is so important a factor in the early history of swine breeding in the Miami valley, we may first consider it, to better understand the part played by the several breeds em ployed in the make-up of the one breed, which, following the law of "survival of the fittest," has survived and superseded all the others, and has become the chief in the comnties and State where it hal its origin.

\section{TH: BRKKHUKE ELEMENT.}

By noting characteristics of the sereral breeds employed in the early formation of the Berkshire breed, one may see why they were used, and where the lop ears, samuly or reddishhrown color, spotted with black, described by Prof. Low in 184 , came from. Then, by following aloug down a quarter of a century, one will see how, by selection, these mmlesired features were eliminated, and how, by judicions crossing and selection, have been substituted the erect ear, the solid black color, artistically relieved by the clean white on the face and 'ieet and tip of the tail.

No artist's brush could place the colors more deftly and in more complete liarmons. The art of the breeler is further handsomely illustrated in the molding of the approved form. the graceful ontline. and in securing a harmony of colors now accepted as that of the ideal stambarl Berkshire. But this was reached only by persistent and long-continued solection and use of crosses intended to eliminate or correct the undesirable characteristics of the early specimens of this noted breed. A. B. Allen sass that in 1841, aged men in Berkshire, England, told him that the breed had been known by them 
from earliest childhood, and yet he and they were still using Siamese crosses-so persistent were the original colors and traits and tendencies to reversion to the hateful characteristics of the old English hog, such as slow feeding, coarseness of ear, hair and form, and the mixel, uncertain colors. Prof. Low tells of the use of the Chinese boars as late as 1842 , to refine and improve the feeding quality of this long-known breed.

\section{MON(GRELS, OR MIXEN BREENS.}

The Bedfords, or Woburns, are spoken of in the Genesee Farmer of 1838, as having strenuous advocates in Massachusetts and neir Baltimore. In Bedfordshire, England, the Duke of Bedford, who was a successful breeder of Berkshires, is spoken of as an advocate of the Bedfords as a most prolific breed.

In Massachusetts, the name of Woburn was given the breed. Youatt says of them (p. 96): "Some admirable pigs were sent to the great cattle shows of London. They were crosses of various kinds, in which it appeared to us the Suffolk strain was prevalent." Affleck (p. 86), in his chapter on hogs in Ohio and Kentucky, says: "The variation in the character of the half dozen different sorts of Bedfords is also great in size, color and form." He believes those in America were descenderl from an importution by a Mr. Parkinson, an Englishman, who lived near Baltimore some eighty odd years ago. These were most probably a mongrel from use of Berkshire and Sussex hogs. As bred in Kentucky and Ohio in 1840, Mr. Affleck says: "They vary a good deal in appearance. The head, neck and ears are fine, the latter somewliat rounded and leaning forward and outward; the shoulder generally good, thongh from close breeding there is a sinking lack of the shoulder in a majority of them; the back otherwise re. markably fine, shightly arched, very broad, the ribs coming finely out and supporting the belly better than is common in any other breed; the loins slender, but high above the slıoulders to a very great degree; the rimp) drooping rather suddenly; the ham large, but not as thick and round as it might be ; $t$ wist fair ; the flank in some good, in others badly tucked; the legs generally so good as to resemble those of a deer much more than of a hog; the bones stout and, though large, not too much for an animal of their size, which is equal to 500 or 600 pounds at eighteen months or two years, with good keep; 
the skin good and the handling very fine; the hair long, coarse and harsh; said to fatten kindly at any age and upon a less amount of food than any others." The celebrated Banter pigs were of this breed, and fed against a pair of imported Berkshires, "beat them a long way."

As to color, "some were white and some were sandy, with numerous large black spots." The same writer says of the improved Berkshire of 1840 , he fully believes "they will surpass the Woburns on similar keep." He says : "The impioved Berkshire more nearly approaches the ne plus ultra of a perfect animal of this kind than any other. His form is perfect; his legs are, however, too frequently faulty, though by no means always so."

The Berkshire was first introduced into the Miami valley in 1835, by Mr. Munson Beach and Mr. John Reed, from Albany, N. Y., the former brirging a boar, Dick Johnson, and the latter a sow, Superior.

\section{BYFIELDS.}

In 1838, the Genesee Farmei speaks of a formidable rival to the Bedfords as having arisen in the eastern part of Massachusetts. Essex county claius tlie honor of originating it as follows: "A farmer in Byfield found, accidentally, in the market, a pig of remarkable appearance, and this laid him the foundation of the breed known as the Byfield breed."

Mr. Aftleck described them as he found them in Warren and Butler counties, Ohio, in 184:, where then they were highly esteemed as a cross with the Russian. He says: "Byfields are of great size, white, with heary lopped ears, flat-sided, but of great length, and others that are beautifully white, their ears small, pointing to their nose, broad back, deep chest, large jowl, short nose, dished face and thin hair." (P. 86, Aftleck.) Different gracle crosses of these and Russian, and again with the Chinas, hare produced the large hog known as the Warren County log.

THE IRISI GRAZIER.

In 1839 , three Irish pigs were brought to Cincinnati by the father of W. W. Greer, of Oxford, Ohio. These pigs were brought, as thonsands of others have been before, to America by emigrants from all parts of the world. Mr. Greer, Sr., lived near the seacoast, where they raised vast quantities of potatoes, on which the hogs were raised and fattened. Martin (p. 98) says of Irish pigs: "The plan of fattening on potatoes 
is not calculated to do justice to the most approved breeds." IIc further says (p. 9S): "Latterly the introduction of some of our hest breeds (from England) with which to cross the old Irish swine, had been attented with decided success, although there is roon for further improvement. Berkshire, Suffolk, Yorkshire and some Chinese boars and sows have been introduced." Thus we see that the so-called Irish Grazier imported into Ohio was a mongrel. These Greer pigs went into the hands of William Neff, a pork packer of Cincinnati, with whom Mr. Greer was employed in cutting pork the first winter of his residence in Ohio.

Mr. Neff also imported other Irish pigs and sent them into Warren County, where their impress on the swine of that region was marked and favorable.

Mr. Affleck, speaking of the boar, Poppet, imported by Wm. Neff, said: "He would weigh about 450 or 500 pounds when matured, and is a very finely formed animal." Some of that importation and their descendants carry their ears pricked; they have fine length, a splendid barrel, good legs and very fair hams. The hair is scant, though fine, and the skin unpleasantly scurfy but hundling weil. The cross of the Berkshire boar and Irish sow was called Bettys, and was considered, by many, better stock than either. In this connection. Mr. Affleck said, in 1842: "The Berkshires, Woburns and the Irish Graziers seem to us the most likely to be of most use, and are certainly those attracting most attention at this time" (1842).

In the Western Stock Journal of 1870 , published by J. H. Sanders \& Co., at Sigourney, Iowa, T. J. Conover said: "The Irish Grazier is white, with a few spots of black ; upright ears, light jowl, fine coating, and would fatten at any age. They are the stock of hogs that gave the Poland-Chinas their fine coating and symmetrical form." He aiso said: "John Harkrader took an interest in the Irish Grazier and commenced an improvement on that breed."

\section{THE RUSSIAN HOG.}

Of this breed, Cuthbert Johnson, in his Cyclopedia of Rural Affairs, after describing the several fresh breeds of swine, speaks of "other European breeds." Among these he names the Polish and Russian breed as one and the same, and describes it as being "generally small. and of a reddish or yellowish color." Albert D. Thaer- of Germany, in his great 
work, The Principles of Agriculture, 1810-12, in enumerating and describing the breeds of swine in North Germany, says: "The breeds of swine best known in North Germany, but nevertheless crossed in various ways, are the following: Moldavian, Wallachian and Bothnian pigs, distinguished by great size, dark gray color and very large ears.

"The next class named is the Polish, or, more properly speaking, Podolian pigs, also very large, but of a yellowish color, and having a broad brown stripe along the spine. These two races furnish very large pigs for tattening, but they require a proportionately large quantity of food; besides, they are not very productive; the sows seldom have more than three, four or fire young ones at a birth."

We are all well aware that what Thaer has here said of this Polish or Podolian pig of North Germany has been the reliance of some who have tried to argue the Russian hog out of exist ence. Though the two tawny breeds agree in the stripe down the back, Thaer says: "The Polish breed seldom has more than three or four or five young ones at a litter," while it is notorious that the Reds and their English ancestors are most prolific. It is not probable that they are of similar origin. That there was a large white breed, known by the farmers of Ohio as much as serenty-five years ago as the Russian hog, there is abundance of living and written testimony. James E. Letton, of Millersburg, $\mathrm{Ky}$, in 1840, wrote the following description of them: "Their color is generally white, with long, coarse hair; head long and coarsely featured ; their ears are not so broad as the common variety of the comtry, yet longer and narrower, and come regularly to a point, projecting forward, and they do not appear to have so much command of them as other breeds; they lave fine length and hight, their bone is large and fine; they stand well upon their pastern joints and trackers; quite industrions : they are thick through the shoulders, indifferently ribbed (or sudlenly inclined down); their plate or kidney bone rathes narrow and ovaling than otherwise; hams pretty gool, though not so good as the Irish, the Bedford or the Berkshire. Yet preferable as is the variety, they do not grade so well as many others; they want more time to bring them into market than the above breeds. Give them from eightern to twenty months' age, they will make very large hogs; they are quite prolific, their usual number being from nine to twelve pigs a litter. I have found their cross with the ibove-named ureeds 
to be a valuable acquisition to their grazing, aptitude to fatten and rapid growth at the same time." That this Russian hog was extensively used as one of the earliest crosses for the improvement of the swine of Ohio and Kentucky, is evident from extant writings and living testimony.

In no other description of breels can we find the counterpart of that back and loin which has cost us so much time and care to correct. Mr. Letton well described it as "indifferently ribbed, or suddenly inclining down, their plate or kidney bone rather narrow and ovaling than otherwise."

The old Harkrader sow had this Russian back, as well as the color, the large, fine bone, and the strong, short pasterns and trackers. How this hog came to the Miami valley and Kentucky is not known. His source and coming are indefinable, but that this so-called Russian hor was highly esteemed as one of the first crosses to improve the common hog of the country, there can be no question. As to the color, Mr. Letton says they were "generally white."

T. J. Conover said, in 1870: "The Russian hog was sandy and black, with white," but, like hogs generally of that date, their color seems not to have been clearly defined.

\section{THE CHINA.}

The breed which did the most for the improvement of the hogs of the Miami valley, as they did for the improvement of swine in England, is the China. The first introduction of this breed in Ohio was in 1816, by the Shakers of Union Village. They were called the "Big China hogs." They were bought in Philadelphia by John Wallace, trustee of the Shaker society near Lebanon. There was one boar and three sows. One sow had some sandy spots on her, in which appeared some small black spots. The boar and other sows were white. By their use on the mongrels by the Russian, Byfield and common hogs, came the Miami Valley hog. That this Shaker importation of Chinas was pure China stock, there is reason to doubt. Nevertheless, they impressed, in a wonderful degree, their offspring with a quicker feeding quality, that seemed to be the leading idea in the improvement of that period.

There are frequent allusions to China hogs and their value, by writers in the Genesee Farmer, The Cultivator and Western Farmer, prior to 1842 . They were used and esteemed in the East and West, and made their impress on all breeds with which they were crossed. The use of the China has been ben- 
eficial in correcting coarseness of form, in quieting the restless disposition, and increasing the tendency to fatten at any age, and refine the texture and quality of flesh.

\section{THE RED HOG, CALLED "POLAND."}

There was another element that we cannot omit, which seems not only to hare heen the very apple of discord among some of our friends, but its impress among the hogs of Ohio and the West is almost as marked as that of the noted Tamworth boar on English breeds. Their color and vigorous growth seemed to attach themselves most persistently to their posterity, and were potent on all crosses. Whether they could be called a distinct breed we will not here discuss. Affleck and Millikin clain not, but that one Asher, of Chester, Butler county, Ohio, a native of Poland, had red hogs which he claimed to hare imported from England, there is strong proof. There was frequent allusion to them in the writings of that day, and to the name Poland given to hogs of their type after 1838. We have a letter from B. G. Schenck, of Franklin, Ohio, in answer to inquiry by L. N. Bonham. He says: "I remember once to hare spoken of the red hogs and pigs I saw when a boy, at an old Polander's down near Chester. I renember to hare gone with my father to this Pole's to see those red pigs, and I remember now just how they looked. They were of a bright, sandy color, with small black specks all orer them. They resembled, in make, according to my recollection of the pigs I saw there, and those raised from the pair my father bought at that time, the Berkshire of to-day, except that thes were a little deeper in the borly, had a flatter rib, and were shorter in the legs. I remember the Polander telling my father that they were the sandy Berkshires, of England, and that he had imported them. I remember the old imported sow and a yearling sow, a pig of hers. They both had litters of pigs at the time. My father crossed them with his hogs, and for years after there would be a pig with the features of the Polander's hogs. I still think that the name Poland, in our Poland-China logs, came from this old Polander."

Here we hare an element that has made a lasting impression on the hogs of the valley and the whole country. The sandy or reddish color is one that has characterized so many of the breels in their early history, that it has wonderful staying qualities. It never has been a popular color. The early English breeders did not fancy or seek to perpetuate it, nor have 
American breeders. Yet in the early history of swine in America, when color counted but little and growth and feeding qualities much, the law of selection did not then exclude animals of sandy markings as it now does, since fashion makes the old markings unfashionable.

That the law of selection, regardless of color, produces profitable hogs, we know. The record of weights made in fattening establishments of an earlier day will make this clear. The books of Wren \& Schaffer, of Middletown, Ohio, show that they packed, in 1879, a lot of thirty-eight Poland-China hogs, averaging six hundred and thirteen pounds gross at twentyone months old, all fattened by one man in Butler county. From a table at hand we quote gross weights of six hundred and twenty-five raised in Butler county, Ohio, and sold to packrrs in 1870 :

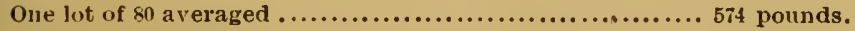

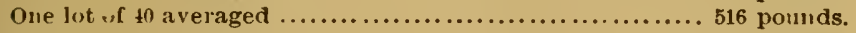
One li; of 38 averaged $\ldots \ldots \ldots \ldots \ldots \ldots \ldots \ldots \ldots \ldots \ldots \ldots \ldots, 5, \ldots \ldots$ pominds.

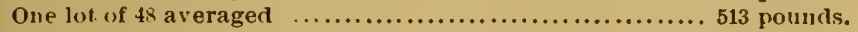

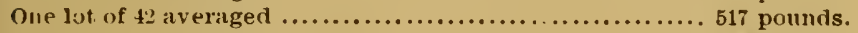
One lot of $: 0$ averaged $\ldots \ldots \ldots \ldots \ldots \ldots \ldots \ldots \ldots \ldots \ldots \ldots \ldots \ldots, 504$ pounds.

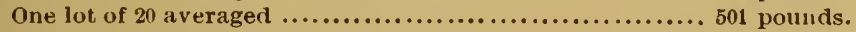

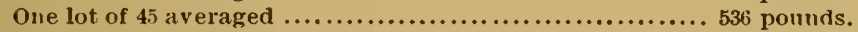

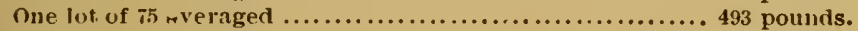

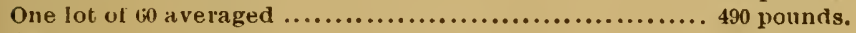

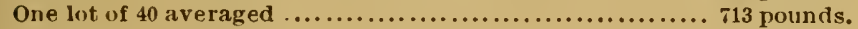
One lot of 12 averaged $\ldots \ldots \ldots \ldots \ldots \ldots \ldots \ldots \ldots \ldots \ldots \ldots \ldots, 773$ pounds.

To show that stis breed had. in 1870 , attained unsurpassed excellence in their readiness to fatten at any age, and their rapid growth, we quote the weights of two lots of pigs fat. tened when eleven months old:

One lot of 30 averaged, gross ........................ 384 pounds.

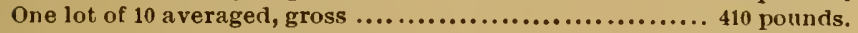
One lot of 38 , older, averaged, net.....................528.89 pounds. One lot of 2 , older, averaged, gross .................. 719 pounds.

The net average of this last forty pigs was five hundred and thirty-eight pounds.

Such a record shows not only skillful breeding, but rare skill in handling and feeding. It tells, too, of the superior natural advantages of a region where such a breed should be originated and produced by an intelligent and persistent application of the law of selection. 
Discnssions by the Press and by indiriduals for nearly a half century, have been the callse of searching and thorough inrestigation into the matters connected with their early history, the time and manner in which the first crosses were made, and upou what foundation, together with the later crosses and manner of breeding, which combine to make them the leading and favorite breed in many sections famous for the valne, size, and quality of their hogs. Owing to the great interest manifested on these points, we hare given them much careful study and examination, for the purpose of getting at the bottom facts for the public benefit; but it seems well-nigh impossible to harmonize the conflicting statements of those who ought to be best informed, or to expect the champions of the rarious riews to be pleased with such conclusions as do not accord with their own.

On many points, all who have studied the question closely agree, and on others (of perhaps minor importance to the public) some of the disputants are as far apart as the poles, but we believe none dispute that the main crosses towards its formation as a definite and distinct breed were made in that part of southwestern Ohio lying between the Big Miami and Little Miami rivers, mainly the counties of Butler and Warren, during the years from 1835 to 1840 . It is also generally conceded that the groundwork was stock locally known as "Warren County" hogs, which were the result of crossing together the Berkshire, "Byfield," the "Russia," the "Big China," and perhilps the "Belford" breeds, all large, coarse hogs and slow to grow and fatten, except the "Big Chinas," which possessed the very opposite qualities.

Hon. John M. Nillikin, who lired in Butler county well-nigh serenty year's, forty-five of which he was a farmer, paid special attention to searching out the his. 
tory of this breed, its material and makers, and his statement to the author was this:

"The truth is, no one man can say he had more to do in the formation of this breed than another. It was the result of the labors of many. It grew out of the introduction of the China hogs by the Shakers of Union Village, the crossing with the Russia and Byfield, and the subsefrent crossing with the Berkshires, and then with the Irish Graziers. After 18 11 , or $18 \pm 2$, these breeds ced'sed to exist in either Butler or Warren counties, and (in 187\%) have had nothing to do whatever with thiz breed for the last thirty-four years."

Controversies as to the precise crosses, and by whom and under what particular circumstances they were made fifty years ago, to form the breed now known as Poland-Chinas, may interest a few ; but what is rastly more important to millious of people, is the fact that there has been prodnced a race of swine, now bearing that name, that very many severely practical and intelligent men consider the best pork-packing machines known,-in fact, nearer what the farmers of the great central, corn-producing West need, than any other single breed in existence.

Their size, color, hardiness, docility and good feeding qualities make them farorites when purely bred, and where more fineness of contour, quicker maturity, and a little less size is demanded, we are satisfied the sows bred to Berkshire boars produce the best feeding and farm hogs in the world. 


\section{$\mathrm{O} \Lambda \mathrm{P} \mathrm{TH} \mathrm{R} \mathrm{I}$.}

\section{TIIE CHESTER WHITES.}

Knowing Mr. 'Thomas Wood, of Chester enunty, Pennsylvania, to be one of the oldest and most reliable breeciers of the Chester IThites, and familian with them from the begimning, we applied to him as a source of reliahlo information as to their origin, early history, hreeding, ete.

IIe writes: "I'lie Chester County White hog is anativo of Chester comty, Pennsylvania, where the breed originated. The first inpulso to the improvement of swine in this connty was indued by the introduction of a pair of very fine white pigs, brought, from Bedfordshire, lingland, by Captain James Jefrries, of this county, and put upon his farm on the Brandywine Creek, near West Chester, the combly seat, in the year 181s. Some of our more cuterprising farmers, secing these fincly-bred pigs, wero intuced to commenee an improvement of their swine by a cross of these, their progeny, and others of the best hogs of the county, and by continuing a careful selection and jundicions crossing for many yeurs, have produced the Chester. White of to-dily, a most desirable, well-formed, good-sized, easily-fattened, and perhaps the best bacon nog for the general farmer in this or any other eonntry.

"I have been paying eonsiderahle attention to the im. provement of the Chester IIhites for over forty yeurs, and wils among the first to disseminate the stock over the United States. I have shown them at numerous agricultural exhihitions; at the exhibition of the United States Agricuitural Society, held at Philadelphia, in 1S56, I reecived the Soreiety's diploma for the liest pigs; at tho Uniterl States Agrienitmal Firir, held at Richnomi, Vat, in 1858, I exhibited ('heste1. Whites, and they took all tho highest prizes offered by the Suciety ; I also exhibited 


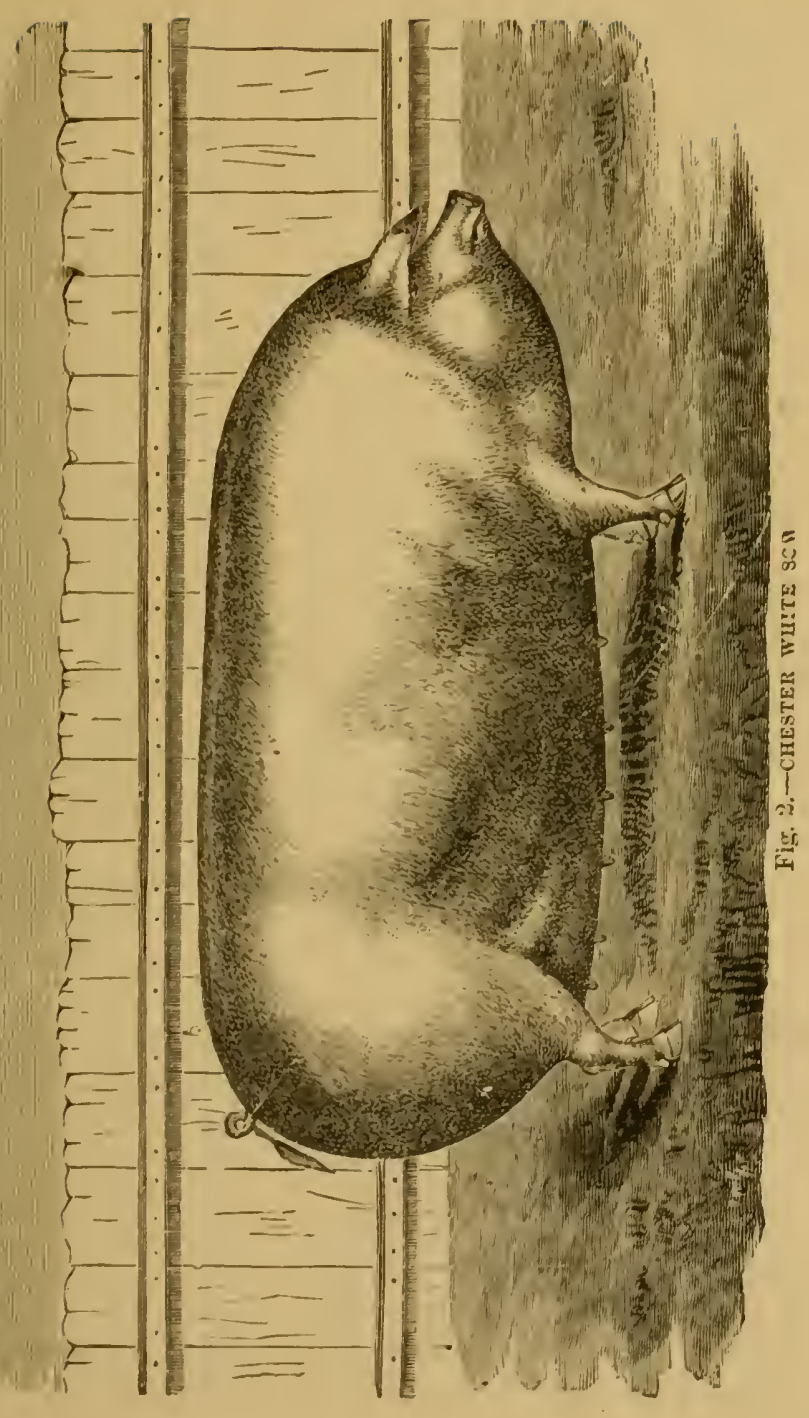


them at the joint fair of the States of Virginia and North Carolina, held at Petersburg, taking not only the highest premium awarded, but also the sweepstakes premium for the best sow, with considerable competition with other breeds at all these exhibitions.

"The Chester Whites have been successfully exhibited at several fairs of the Maryland Agricultural Society; also at nearly every fair held by the Pennsylvania State Society, as well as by many County Societies, in competition with most other breeds, while in many other States - they have successfully competed with all the foreign and bome-made breeds.

"Some thirty years ago, the 13erkshires were introduced into Chester county, where some of our farmers tried and kept them very nice, and exhibited them at the agricultural fairs; but they did not seem to take well with our farmers at that time, and were displaced by Chesters.

"A few years later the little Suffolks, that were making quite a stir in the hog line in New England, were introduced into our county, and afterwards the Essex, but neither breed flourished here, and the Chesters quietly superseded them.

"I tried them all, but found none of them superior to our own breed. Some of the Chesters had been crossed with the black breeds, and it took our farmers eight or ten years to get rid of their spotted hogs, which was finally pretty well accomplished, and the Chesters again held sway over the county, and hundreds and thousands of them were shipped to different parts of the United States, Canada, and the West Indies. During this time, many unprincipled parties shipped any kind of a white pig they could pick up in the county, which they would call genuine Chesters; this lowered the popularity of the breed wherever such pigs were sent. This caused a great falling off in the demand for our pigs, and again the Berkshires were introduced into this and adjoining counties, they 
having, in the thirty years since their first introduction, been mueh improved, and being popular abroad, some of our swine breeders procured them to breed for shipping purposes, and, as every generation must try the different kinds of stock for themselves, many farmers bonght the Berkshires to see if they possessed any alvantages over the Chester Whites, it being said that their hams were not so fat, and wonld sell more readily in market. After many years of trial, many farmers said that the white hogs were best adapted to their wants.

"The Yorkshires have also been recently introdnced (in their greatly improred eonclition) into our county, and are quite as popular as the Berkshire.

"I will here give the result of my experience with the Chesters and Berkshires: I procured from a noted breeder in a neighboring State, two Berkshire pigs abont ten weeks old, and with them, in a pen, I pat two Chester Whites, from a litter of our own, after sereral of the larger ones had been sold. They were a few days younger thin the Berkshires, which were masters at the trough, and they remained so, knocking the Chesters about as though the whites had no riglits the blacks were bound to respect. After feeding the four together for seren c1 eight months, by which time the Chesters weighed serenty-five pounds, each, heavier than the Berkshires, we killed and salted them for our own use, intending to find ont which made the best bacon, and we found the Berkshire hams gave more lean meat, though somewhat dry and hard, while that from the Chesters appeared to be more soft and juiey, and was considered mueh the best for our own eating; but those who do not like the fat, juiey ham, wonld prefer the Berkshire, which is also niee.

"It might seem that enough had been written and published in our agrienltural papers abont the pure bred hogs, when we evidently have no sueh, and the further we have got from the old English and China type, the 
better the hog. The Chester White, made in Cheste county, Penn.; the Poland-China, made in Butler county, Ohio, lay no elaim to any infusion of foreign blood, and are two of the best breeds of hogs in the United States. The black hog, with white feet and a white strip in its face, now called the Berkshire, and the white hog, with thin, curled hair, short head and rery crooked face, called Yorkshires, are both very well made and good hogs. The Chester White breed is now the longest established, mmixed with foreign crosses, of any breed with which I am acquainted, and therefore comes nearest a pure bred log at the present time.

"Some objeet to them, as being too large for the porkpackers : this I cannot look upon as an objection, as the Chesters will fatten readily at any age, and can furnish any weights the packers may desire (from 200 to $300 \mathrm{lbs}$ )

"I think they would be more profitable than any small breed, which has to be kept over winter to attain the desired weight, as Chesters, pigged in the spring, will readily attain the desired weights by killing-time in the following fall or winter, and by keeping them longer they can be grown to weigh 600,800 , or eren 1,000 pounds. A Chester White exhibited at the Exposition in Philadelphia was said to weigh upwards of $1,300 \mathrm{lbs}$. live reight.

"We seldom have fatal diseases among our hogs; many of the diseases of swine, as of the sheep, enumerated by the English, I think nerer oceur in this country. As to the Chester Whites being exempt from the attacks of 'cholera,' Thomas Hiner, of Edinburgh, Indiana, stated to me some years ago that all his hogs, serenty in number, were attacked with eholera, and the only pig in the whole herd that recorered was a Chester sow, the only one he had. I do not recollect ever hearing of a Chester dying with the cholera, yet I see no reason why they should be exempt. I think we have never had any hog cholera in eastern Pemusylvania, except in a few instances, 
where pigs were shipped from the West for sale to our dairies."

We have said that the Essex were essentially the same find of hogs as the Suffolks, cxcept in color and the quality of their skins : 'The best of the Chester. Whites stand in about the same relation to the Poland-Chinas, for if a Chester was partially black, he would easily be mistaken for a Poland-China, and a strictly white Poland-China could scarcely be distinguished from a Chester White.

With many persons who suppose they have had the Chesters in their best estate, there is much prejudice against the breed, but, in many cases, we think the Chesters receire the harshest criticisms from parties who never owned one purely bred, and, in all probability, do not know what they are, or how they should look. Where the best specimens hare been handled with the same care, and the same judgment used in mating, breeding, and feeding, that is bestowe? on other well-bred, well-fed animals, they have been reasonably sotisfactory, and hare justly earnest adrocates and admirers.

The occasion of the bitterness toward so many hogs that hare been called Chester Whites, is that their popnlarity, and the consequent demand increased, while they were comparatively few in numbers, faster than the supply, which stimulated many unprineipled parties in eastern Pennsylvania to engage in advertising and shipping any white pigs they conld obtain, regardless of their character or breeding, and thousands of innocent purchasers of these mongrel pigs supposed they had pure Chesters, and the subsequent failures with them cansed no little loss, mortification, and deep-seated disgust with the very name. One firm alone, that perhaps raised some of their pigs, publicly proclaimed that they had shipped annially, for three or four years prior to 1870 , from 2,500 to 2,900 pigs, and the advertisements of all such parties intimated, 
indirectly, that their ability to fill orders for choice selected pigs was unlimited.

A gentleman residing in Chester county, gave the New York Farmers' Club sume correct ideas as to the way the business was conducted, as follows :

"I live in Chester county, aud know something of the operators in this famous breed of pigs; know something of their business, iis extent, and their ability to meet the demand with pure Chester Whites-pigs pure enough to reproduce themselves. There are, no doubt, a great many breeders who keep the stock mmixed, but if you knew the enormous demind from altroad, independent of the local wants, you would see how little likelihood there is of meeting it with pure stock. The consequence is, every nook and corner is scoured for pigs-pigs that are not black, that is all that is required.

"Drovers, hucksters, and almost every other itinerant, are on the lookout for pigs, until they have tripled in price from what they were a few years ago.

"Last fall, a neighbor had several litters of very ordinary pigs, which a farmer engaged at a very young age, to make sure of them; but a hog-dealer-as they are called-came around in a few days, bid higher, and took the most of the lot.

"Another neightor procuret a pair of pirs from one of the breeder"s we have in the county, and the first litter he raised from them were nearly all more or less spotted with black, thus showing uumistakably bad blood."

When the reaction following this set in, it was, of conrse, severe. The graceless seamps who followed this business, have given the Chester Whites a much worse reputation than they deserve, and tho question as to whether the true Chester White is an established breed, is not worth discussing with those who really know them.

They are appropriately classed with the large breedion growing, if kept, to almost any size, and hold their white color perfectly under all circumstances. Docility and cleanliness are marked characteristics with them, and the sows make an excellent foundation upon which to cross boars of any of the more refined breeds, the offspring in- 
heriting size from the sow, and early maturity and fine feeding quality from the boar.

The tendency of late years has been to reduce the Chester's courseness of bone, head, ears and hair, and it is a marked improrement.* Breeders in Ohio and elsewhere have claimed to make vilriations in the types reared by them during several generations of the stock, entitling it to designation and registry in a separate record as "Improvel" Chester Whites, but whether the "improvement" over the best of the Chester county stock, as bred from 1805 to 1880 , is a material one, is an open question.

'Taking the specimens of the breed shown at the Columbian Exposition in 1893 as representing its best, there was little to indieste that the Chester Whites, at that time, were any improvement on their ancestry of twenty-five years before, and the contrast they presented, alongside many of other breeds, could scarcely impress the unbiased olserver as strikingly favorable.

Where farmers hatve large Chester sows that are too coarse, at cross with a good Sulfolk boil will give pigs with fine points and most exeellent feeding qualities, fattening readily from the time they are weaned.

We have had considerable experience with the Chesters, perhaps as good as Chester county afforled, and their merits are many, but they were discarded, with other white breeds, for their one failing in the Western climate and under Western treatment, viz., liability to skin diseases, especially mange. Harsh treatment and exposure tell severely against the hardiest white hogs, but we believe judicious management and breeding will yet do much to rid them of this apparent tenderness.

* The heavy lopped ears, coarse heads, long, coarse talls and hair are much less characteristic of the breed now than they were in lts earlier days, while their coats are of silvery white hair of reasouable tueness. 
'The National Conrention adopted the following as their description of the

CHARACTERISTICS AND MARKINGS OF CHESTER WIITES.

"Head short, broad between the eyes; ears thin, projecting forward and lap at the point; neck short and thick ; jowl large ; body lengthy and deep, bread on baek ; hams full and deep; legs short, and well set under for bearing the weight; coating thimnish white, straight, and if a little wavy not objectionable ; small tail, and no bristles."

\section{H A P 'T E R $\mathrm{R}$.}

\section{THE BEPKSHIRES.}

For ten years subsequent to 1831 there raged in the United States what might appropriately be called "the Berkshire ferer," and mainly from the efforts of those interested in their importation, and sale at fancy prices, the breed became notorious, if not popular. Miuny substantial farmers, and others, invested in them largely, and no small efforts were made to sustain the mushrom reputation that speculators had made for them, but while they were, eren at that time, logs of excellent breeding and truly valuable, the eareless, negleetful systems then in rogue with too many farmers, were not adapted to maintaining the good qualities given the breed by English breeding and feeding, and deterioration followed. Failing to realize the expectations of those who purchased them, a reaction set in, and breeders became disgnsted with, and so prejudieed against, the stock and its very name, that they would afterwards scareely accept of a Berkshire as a present.

Much of the prejudice then engendered only ceased 


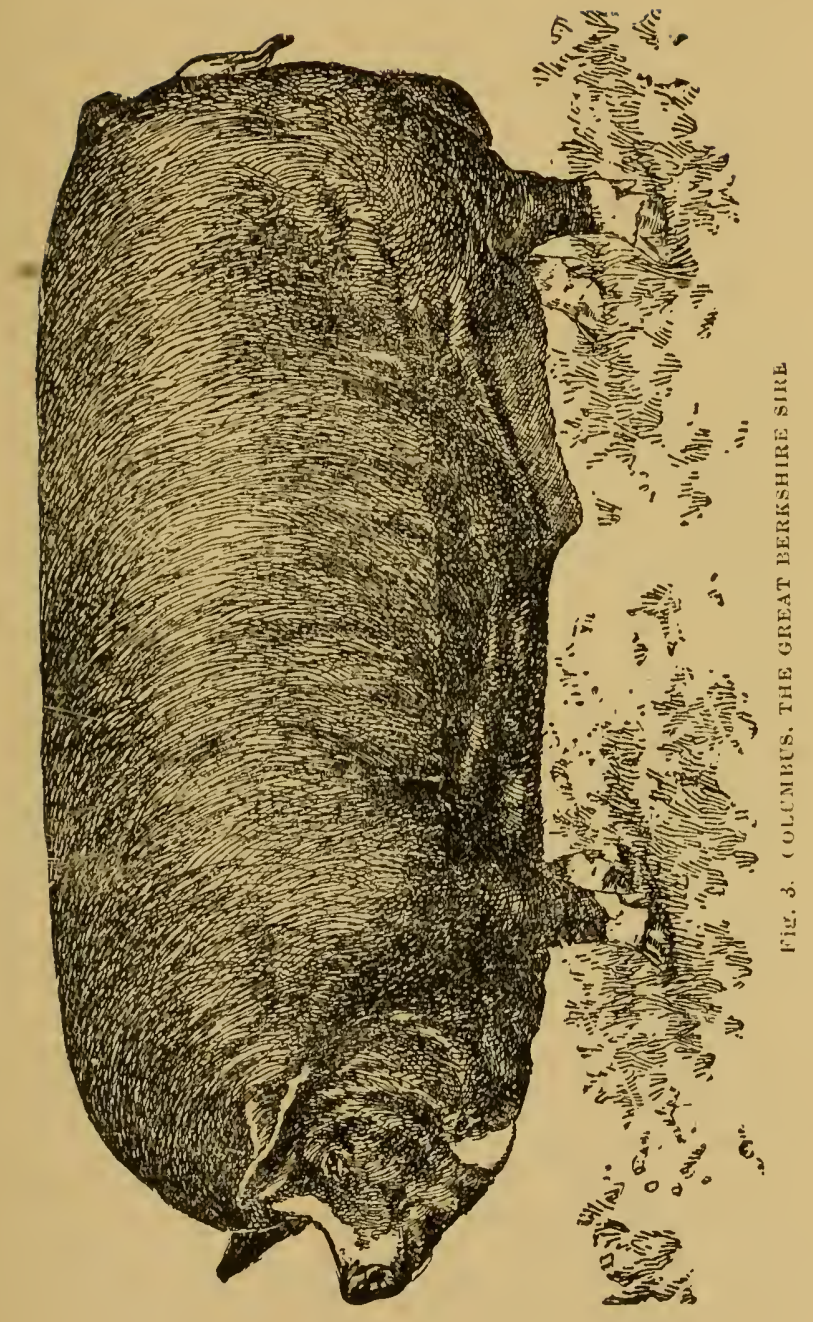


with its generation, and perhaps but little or none of it exists at the present time.

Since about 1865 , new importations, of the finest speeimens of the improved Berkshires that Great Britain could produce, have been made, and the stock has been widely disseminated; being now thoronghly known and appre riated, it probubly stands second to none in the estimation of intelligent pork-producers throughout the United States and Canadas.

While the Berkshires of the present time are probably much improved over those of forty years ago, the spirit of improvement is still abroad, and the standard of perfection is placed high.

Prominent among the good qualities that serve to make them farorites are:

1st. - Great musenlar power and vitality, which render them less liable to disease than many other breets.

2d.-Aetivity, combined with strong digestive and assimilating powers ; henee they returu a maximum amount of tlesh and fit for the food eonsumed.

3d.--'The sows are mequalled for prolitiency, and as careful nurses and good sucklers.

th.-Whe pigs are strong, smart, and actire at birth, and consequently less liable to mishapis.

sth.- I'hey can be fattened for market at any time, while they may be fed to any reasonable weight desired. 6th.-Their flesh is the highest quality of pork.

rth. - Power of the boar to transmit the raluable cualities of the breed to its progeny, when used as a cross.

8th. - Their unsurpassed uniformity in color, marking, and quality.

It is doubtful if any hogs are nearer thoroughbred, in its best sense, or more eertain to reproduce themselves with fidelity than the improved Berkshires. Crossed with Poland-Chinas they make the best feeding hoys possiblein fact, there is searcely a medium or large breed upon 
which tiney cannot be crossed with advantage, owing to their great vigor and hardiness.

In our own breeding and feeding operations, no breed has been found so eminently satisfactory as the best Berkshires, and we breed them pure in considerable numbers ior feeding purposes, having years ago discontinued the raising of any others.

Their reasonable size, ruick growth, easy fattening, rlocility, uniformity, and hardiness captivater us, and every day's experience but adds to our admiration of them.

The pigs, even when coming in the most unfavorable seasons, have a tenacity of hold on life that is truly wonderful.

Many of the meanest hogs and those of the worst dis-. position that we have known were called Berkshires, but they sustained about the same relation to the true sort. that the propagators of them did to intelligent farmers and breeders.

'The Berkshires having hecome so numerous, and their excellence so generally recognizerl, the friends of the breed organized in March, 1875, at Springfield, Illinois, the "American Berkshire Association," having for its object the "collection, preservation, and dissemination of reliable information on the origin, breeding, and management of Berkshire swine, and the publication of a Herd Book, or Record of Berkshire pedigrees."

One of the first steps of the Association was to offer a premium of $\$ 100$ for the hest approved orignal essay on the origin and management of lierkshires. 'The premium was awarded to A. B. Allen, Esq., of New York, the historical and descriptive portions of whose essay are presented in subsequent pages.

The entire essay appears in Vol. I of the "American Berkshire Record," and we are safe in saying that the subject has not, in any other published paper, been treated by any one so thoroughly familiar with it as Mr. 
Allon, and wo sire a emsiderahle portion of it here in licu of any antempte to treat the sulijoct entrselves.

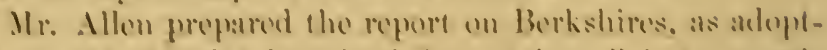

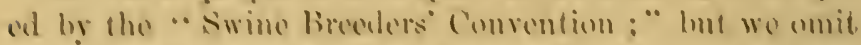
it, as the essiy contains the some, and considerable other informatiun.

'The comrontion angered upon tho following as tho

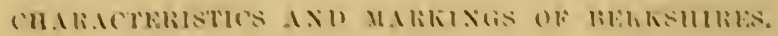

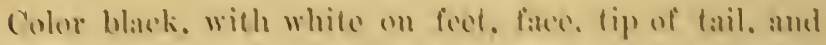
an oceasional splash of white on the arm: white a small

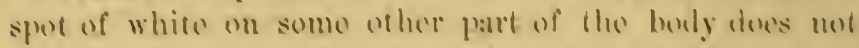

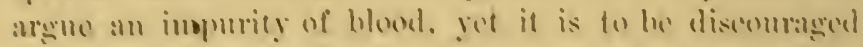
(1) the end that miformity of eolor may be attaimed ly broders: whito

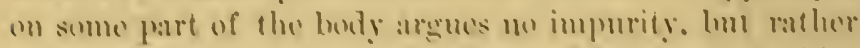

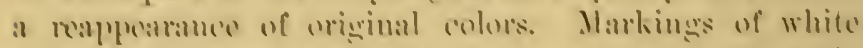

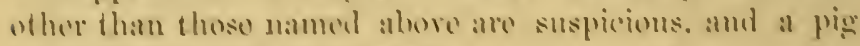
so markicel shomld be rojowal.

Face short, tine, and woll dished, brome betwen the cres: ears gencrally almust wrot. hut sometimes in-

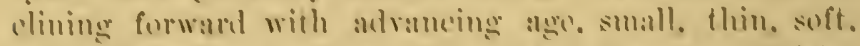
and showing reins: jowl full: now shert and thick:

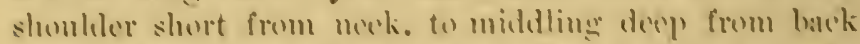
Alown: back brosd and strighte or a rery litte arehed:

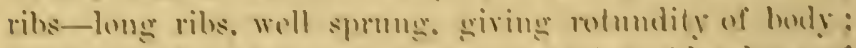
short rils of good lengeth. giving breath and levelness of loins: hips geost length trom point of hip to rmmp:"

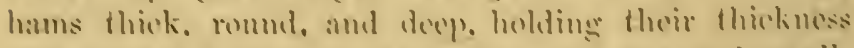
woll bate and down to the hexhs: tail fine :mel small. sot on high up: legs short and line, hut straight and

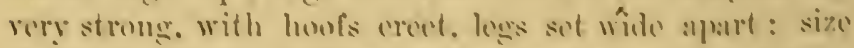
medium : longth modinm, oxtremes are to be arobed: bone the and complat: oftal rery light: hair the and compot: shin pliable.

'Tho Berkshires are hardy, prolifie, and excellent murses; 
their moat in of superior ruality, with fat and loun well mixesl.

$\Lambda_{\mathrm{s}}$ showing the weight, that animals of this breed will attain at an carly atro, it is stater that J. A. Brown, of Miltom, Illimois, solde, in 18\%", a lot of Berkshire pigen of an aserage age of nine monthes, and their averagros weight wats :30:5 pounds.

As indicating thes estimate placed on this breed in lingland, the learlin', work of that, conutry on swing raising mays :*

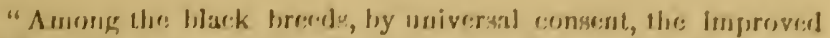

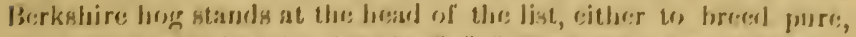

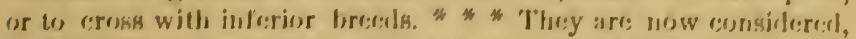
by Berkshirrs farmers, to be divideal inter a miscldes (moslium size:)

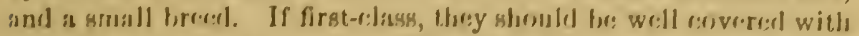

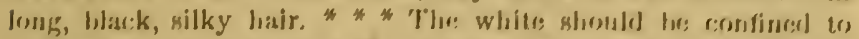
four whike foret, a whoks aprot belwesen the cyes, and a few whites hairs belsind cach shoulder."

\section{IPRMIUS FSSAY.}

BY A. " ALLK.N.

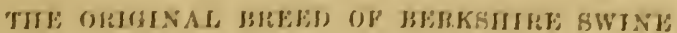

"Tradition, and tho earliest published accounts of what has fong been farticularly distinguishen! hy the natue: of Jorkshire swince,

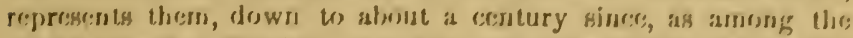
largest bresals of Finglind, weighing, full grown, from ofor) (o) $1,(5)$,

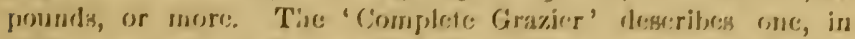

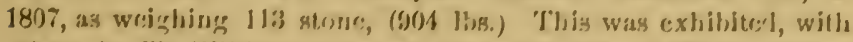
callers, by föir William ('urtis, at thr: csattlos shrow rof Lord Somer-

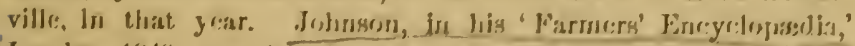

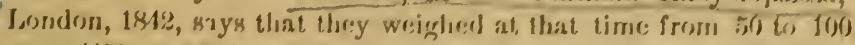

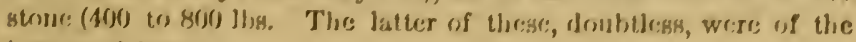
improverl bresel.

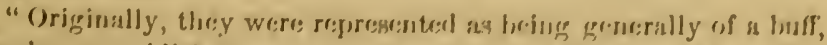

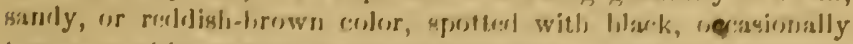

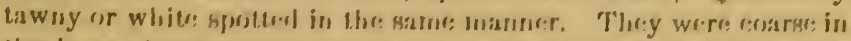

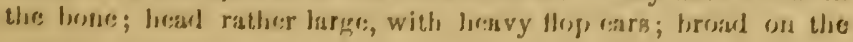

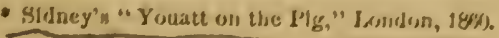


back; deep in the chest; flat-sided, and long in the body; thick and heary in both shoulders and hams; well let down in the twist; bristles and long curly hair, with rather short, strong legs. Their meat was better marbled than that of any other breed of swine in Great Britain-that is, had a greater proportion of lean frcely intermixed with fine streaks of fut, which makes it much more tender and juicy than it would otherwise be. They were conse. quently, from time immemorial, preferred to all other swine there, for choice hams, shoulders, and bacon. They were slow fecders, and did not ordinarily mature till two and a half to three years old.

"It is thus that I find the Berkshire hog figured and described in the carliest English publications to which I have been able, thus far, to obtain access. But in the second volume of the magnificent folio edition, illustrated with colored plates, now lying before me, of 'The Breeds of the Domestic Animals of the British Islands,' ly Professor David Low, published in London, in 1842 , is a portrait of a Berkshire as I have described above, except being of rounder body and somewhat finer in all his points, with ears like most of those of modern breeding, medium in size, and erect, iustead of flopping. This portrait is of a sandy or reddishbrown color, spotted with black; the feet and legs for nearly their whole length, white, slightly streaked on the sides and behind, with reddish-brown. It, of course, represents one of the old breed con. siderably improved, and marked as I occasionally found them in all my visits to Berkshire down to 1867 . But the pigs which I saw thus marked were of the same size and shape, and as fine in all their points, as a general run of the black, slate, or plum colors of the present day.

"FORMATION OF THE IMPROVED BERKSHIRE SWINE.

"Tradition tells us that this was made by a cross of the black, or decp plum-colored Siamese boar, on the old unimproved Berkshire sows. Other traditions assert that the black and white spotted, and eren pure white Chinese boar was also sparingly used to assist in the same purpose. I can well bclieve this; for I often saw swine in Berkshire spotted, about balf and half black and white, in addition to the reddisb-brown, or bufi and black, and so on almost up to the pure plum color or black. The produce of the above cross or crosses was next bred together, and by judicious subsequent selections, the improved breed, as we now find it, bccame, in due time, fixed and permanent in all its desirable points.

"Another feature, aside from the half and half black and white spots hitherto occasionally found to mark the improved Berkshire 
swine, which may be adduced in support of the supposition of a sparing cross with the white and light spotted Chinese, is the shape of the jowls. All these which I have bred in my piggery, or imported at different times direct from China, or have seen elsewhere, had much fuller and fatter jowls than the Siamese. Some of the breeders of England preferred the fat jowls, because carrying the most meat; others the leaner, as they said this gave their stock a finer and higher bred look in the head.

\section{"THE SIAMESE SWINE.}

"In the same volume of Professor Low, which contains the Berkshire portrait as deseribed above, is a colored plate of a Siamese sow. She is a dark-slate, varying to that of a rich plum color. The two hind feet are white; the fore legs and feet white, shaded in front with plum. The face is disbed; head tine, with short erect ears; shoulders and hams extra large; back broad, with a deep, round, and longish body. The sow is represented with a slightly swayed or hollow back, at which we need not wonder, considering its length, and that she has a litter of nine great fat pigs tugging away at her dugs. These, Professor Low says, were got by a halfbred Chinese boar, which, I presume, from the color of the pigs, was white; for some of them were pure white, while others are mixed with slate, or plum and white, and one is a buff, with black spots, like the original Berkshire.

"I will now describe the Siamese swine, such as I possessed and bred for several years on my farm. They varied in color from deep rich plum to dark-slate and black; had two to three white feet, but no white on the legs or other parts of the body. The head was short and fine, with a dished face, and rather thin jowls; ears short, sleuder, and erect; sloulders and hams round, smooth, and extra large; back broad and somewhat arched, exeept in sows heavy with pig or suckling pigs, lut even then it was straight rather than swayed; body of moderate length, deep, well ribbed up, and nearly as round as a barrel; chest deep, and broall ; twist well let down; legs fine and short; tail very slender and well set, with a handsome curl in it near the rump; hair soft, silky, and thin; no bristles evell on the boars; skin thin and of a dark lute, yet when scalded, scraped white; flesh firm, sweet, and very tender, with less lean than in the Berkshire. Although so compact, round and smooth in huild, they had a fine, high-bred, up-headed style, especially in their walk, which instantly attracted the attention of all who called to see them. They were moderately prolific, and as 
hardy as auy other breed of swine I erer kept, the extremes of heat and cold neve injuring them. They were gentle in disposition, very quiet, and ensily liem, and would partially fatten on

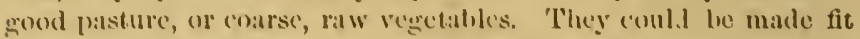
for the butcher at any age; matured at l? 10 is montlis old; and when fully fattened, generally weighe:l from 200 to :00) pounds, occasionally going to 850 , or 100 poumds. They hat very tine hones and light ollal.

"It wals, cloubtless, with Siamese boars as perfect as I have described, that the cross was made oa tlae erighal Borkshire sows, which has eontributed so largely to the lormation of the improwed breed, held in such high estimation for a full ecntury 11 more past.

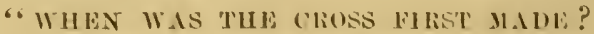

"Several aged men in different parts of Berkshire, of whom I inçuired on my tirst visit to England, in 1811, informed me that they had known there improved swine of the same type as I theis found them, from entiest ehildhood. Fut the must particular, and apparently rediable, aceount I was ahle to obtain, was from Mr. Westhrook, of Pinckney freen, Bysham, who told mo that his father possessod them as early as the year 178?), in as great perfeetion as the best then existing in the conntry. Thus it will he seen that the improvement is now nt least a century obl, and more probably a century and a guarter; for it wonld have taken some years bick of 1780 to begin a new ireed of swine, and get it up t.) at tixed type at that period.

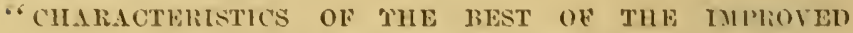

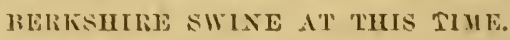

"Snout and head fine and rather short, lout larger in proportion to the body in the male than in the female, and with a holder and more determined expression; face dished and broad between the eyes; jowls full or tlinner, arecoling to the fancy of the breeder; eyes bright and expressive; (ars small, thin, and upright, or inclining their points a litle forward: neek short, rather full in the throat, and hamonionsly swellmir to the shomleles; chest broad aml deep; back broal and moderstely arehed; rumb neario level with it; well let down in the twist: body of good lengeth and depth, rome, with woll sprung ribs, and straight along the sides and under the belly; slomlers, nhove ail, in the bon, extra thick, yet sloping smoothly to the hody; hams broat, romd, deres, and so thick through from sicle to side, particularly in the sow and barrow, that, stauding directly behind, exeent when pretty fat, tho 
silles of the body are searcely seen hetween them and the shoulders; legs fine, strong, of mosterate lengll, and set rather wile apart; fect sniall, with clear, trough hrolis; tail slender and well set, with a handsome curl near the rump; lones fine and of an ivory-like grain and harelnegs; offal very light in comparison to wejght of rarcass; hair fine, soft, and silky ; no bristles, even on the boar; s'sin thin and inellow, witlı clastic handling of the flesh lencill,; (111ick and spirited in movenent; stylish in carriage, and, in the bosir, more esplecially, loold and imposing in presence.

\section{"COLOR ANH MARKING.}

"The most favorite color among the best beeders in Berkshire, in 1811, was a deep rich plum, with a slight flecking on the body of white, or a litule mingling with it of buff; a small blaze in the face; two to four feet white, an'l more or less white hair in the tail. The plum color was preferred to the black or slate, because it carried rather ligher style and finer points with it, a superior ruality of flesh, softer laaj, and thinner skin.

"The alove is no ideal description of choice improverl Berkshire swine, for I found several such in traversing the country, and purchased and sent them home, to grace my own piggery. Nor, with alt these points, were they larking in size; and to sulsstantiate this assertion, I will here note the dimensions of one of those I imported at this time, which I called 'Windsor Castle,' he having been bred and reareul near that magnificent royal residence, standing in Berkshire.

"As he lay down he measiared, in a direct line alongr the side, from the tip of his nose to the end of lis rump, six feet three and a half inches. If measurerl stanling up, with lis head stooping towards the ground, by runing the tape line from the tip of his nose over the head between the ears, and along the back to the end of the rump, as swine are often incasured, it would have made upwards of seven feet long; but I do not consider this a fair wily of measuring. Hisht to top of the shoulder, two fect eleven inches; light to top of rump, three foet; girth close hehind the shoulders, five feet six inches. He was in rather lean condition when I measured him, as I kept him so in order not to be too heavy to serve small sows. It is well known that when a Berkshire is fully fed, in addition to the meat on his sides, he lays two to four inclies more on his lack. I am confident if "Windsor Castle" lad been altered to a harrow, anel fully fattened, he would then have measured three feet and two inches high to top of shoulder, and three feet three inches ligh to top of rump; would have 
girthed around the heart seven feet, and weighed, dressed, at least eight hundred pounds. He was as fine in hair and all bis points, and as good a bandler as the choicest of those of smaller size; and for a combination of size, style, vigor, and noble presence, he exceeded anything I ever saw or ever expect to see in the genus sus. A friend of mine, who was a special nice juclge and breeder of horses and cattle, but who hated hogs, and would go as far to kick one as the celebrated late John Randolph, of Roanoke, Virginia, was in the habit of declaring he would go to kick a sleep; on visiting my piggery and seeing 'Windsor Castle,' was so surprised and delighted with his superb appearance, that he exclaimed he was the only one of this sort of stock he had ever Jooked upon which had any poetry in him, and that for his sake ilone he should henceforth be reconciled to swine.

\section{' SIZE OF THE IMPROVED BERKSHIRE.}

"I have heard of those, both in England and America, whose dead weight, dressed, occasionally exceeded $800 \mathrm{lbs}$.; but at the time I first visited the former country, the general weight, full grown, was about the same as at the present time-namely, from 300 to $600 \mathrm{lbs}$; accorling as the smaller or larger pigs were selected from the litters for fattening, and as they were subsequently fed and attended. The smaller sizes matured several months the quickest, and were preferred in the markets for fresh pork; and for curing also, for those who were particularly nice in the choice of their meat, being rather more tender and delicate than the larger animals.

\section{"QUALITY OF MEAT.}

"The meat of the improved Berkshire, like that of the unim. proved, abounds in a much greater proportion of sweet, tender, juiey lean, well marbled with very fine streaks of fat, than other breeds of swine; but the former is far more delicate now, than the latter ever was. This renders the whole carcass the most suitable of all for smoking. The hams and shoulders are almost entirely lean, a thin rim of fat covering only the outside.

\section{" MATURITY.}

"The improved Berkshire could be fattened at any age. Barrows matured in 12 to 18 months, according as selected from the litters, whether the largest or smallest, and as subsequently feri and treated. It took boars and sows yeserved for breeding aliout six months longer to get their fullest size and weight, not being 
pushed by ligh feed so rapidly as those destined for more immediate slaughter.

\section{" EARLIEST IMPORTATIONS INTO AMERICA.}

"The first importation into the country, of which I find record, was made in 1823, lyy Mr. John Brentnall, an English farmer who settled in English Neighborhood, New Jersey. I became acquainted with his sons after their removal to Orange county, New York, and purchased oi them stock descended from this importation.

"The next were imported in 1832, by Mr. Siday Hawes, an English farmer who settled in Albany, New York. He subsequently made other importations, some of the descendants of all which I added to the stock on my farm.

"I have heard that by the year 1838, a few followed into Canada and some of the Western States, from England. I bought a small lot that came into western New York in 1839; and late that year, Messrs. Bagg \& Wait, English farmers who had settled in Orange county, New York, began their large importation, which they continued for several years, disposing of them mainly in Kentucky, Tennessee, Missouri, and the South. In 1841 I selected in Berkshire, England, and inported into New York, upwards of forty head of the choicest of the Improved Breed of swine I could find there. The above have been followel by numerous other importations down to the present time, both into the United States and Canadit. Those curious as to the particulars of these will find them pristty fully recorded in the various Agricultural journals of America. ****

\section{" ADVANTAGE IN MAINTAINING THE BERKSHIRE BREED.}

"There is a growing taste on the part of the American people, coinciding with that which has been cultivated a long time in Europe, for tender, juicy, well marbled, smoked hans, shoulders, and side pieces, in preference to very fat, salt pork. This should be encouraged, as the former ara not only the more palatable to persons in general, but are unquestionably the most healthy food. Considering these facts, the Berkshire, above all others, should be the favorite swine among us; and we ought to take all possible pains in breeling, rearing, and fattening them in such a manner as to inake a superior quality of smoked ineat, not only for the home, but also for the foreign market.

"Improved inethods of curing and packing slould likewise be adopted, so as to enable us to get as high a price in the Euglish market as the best Irish bacon commands. This, I fund often quoted 20 to 30 per cent above American. 
"Indian corn, which in the United States grows in such abundance, is undoubtedly superior to anything which can be produced in Ireland, for making the best quality of fat pork; but I have heard this questioned as to hams and bacon. Some feeders conterid that fine, mealy potatoes, cooked and mixed with barley, oats, peis, or beans, or several of these, fed together, will produce a superior quality of bacon. This is a matter worth inquiring into, and I would suggest an earnest cousiderition of it on the part of our feeders, and of those engaged also in bacon curing and packing. The Irish have one advantage over the Americans, in the English market; and that is in being so much nearer to it, they can cure their bacon and offer it on sale in a fresher and milder state than we are able to at present. If we should, on trial, hereafter find that it can be sent forward at a profit, in refrigerators, kept lown to a low and even temperature, we could then probably obtain as high prices in the English market as do the Irish, and thus add another desirable item to the exports of America."

\section{II A P T E R V V .}

\section{THE SUFFOLKS.}

The Suffolks are not raised pure, or used as a cross in the prineipal pork producing States so extensively as sevcral other breeds, nor are they so well known to a majority of farmers, who have a belief, if not positive knowledge, that they are somewhat delicate, and diflienlt to raise.

The objections to them are, that they are not large enough, not satisfactory as breeders and unrses, and that their skins are too tender, and thinly haired, to withstand the exposure to which the averige farmer's hogs are subjected.

$\Lambda$ s to size, the best strains of Suffolls are large enough for those who prefer to raise logs of medinm weights, while for quietuess, and casy keeping qualities, no breed 


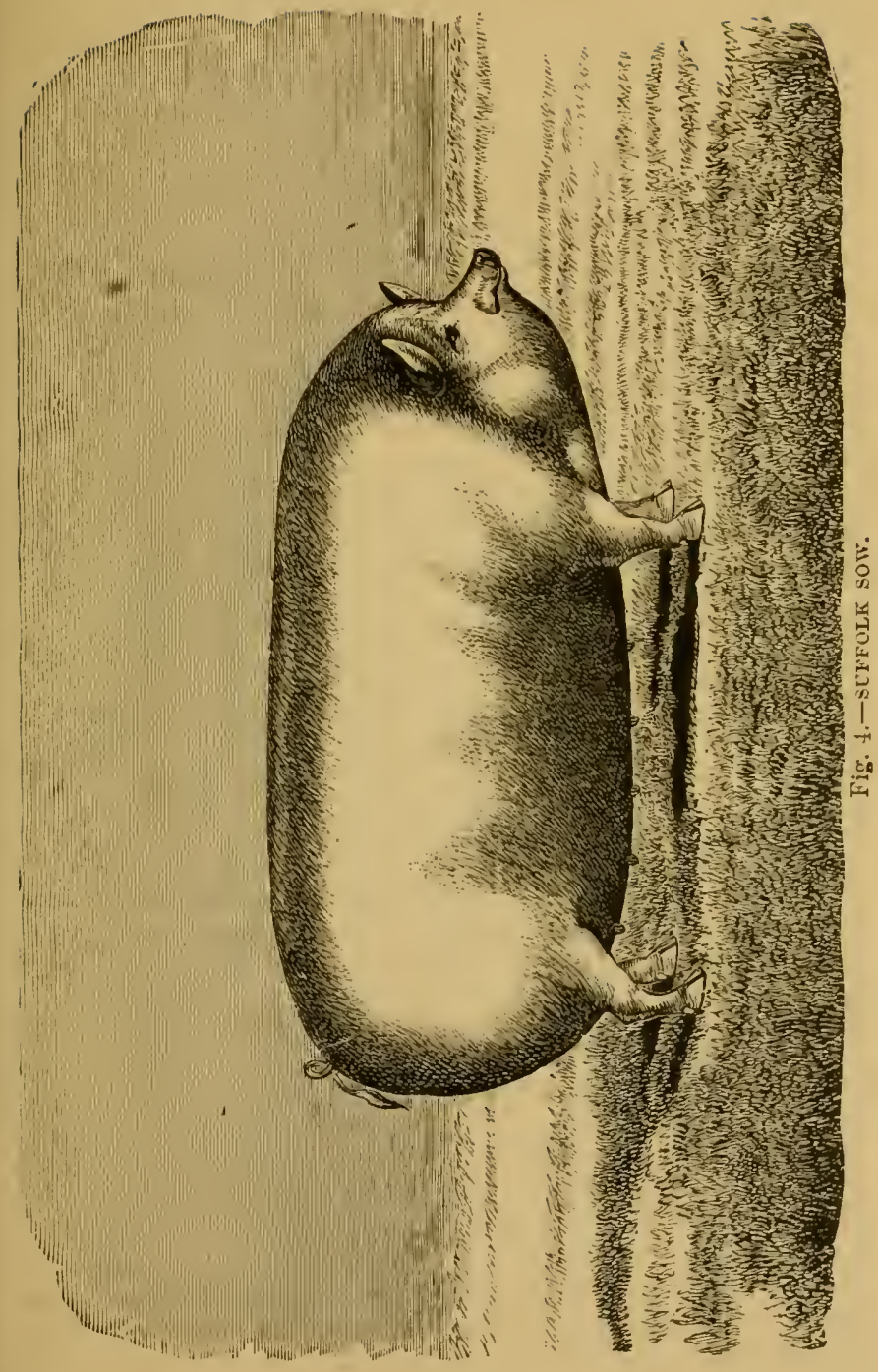


of swine can excel them, and to those who like pets, we wonld recommend a cleanly-kept Suffolk pig in preference to any "poodle," or other diminutive canine, we ever saw. 'The sows are not so prolific, so regular as breeders, nor usually so good sucklers as others that mature less early, and not so predisposed to excessive fatness while young.

Experience with the Suffolks has eonvinced many that the wind, sun, and mud, make sad work with their tender, papery skins, and we have seen them, when reasonably well kept, beeome chapped and cracked all over, and the smaller pigs so mangy and sore as to present the appearance of a solid scab. Of eourse, all Suffolks are not so affected, and we think that in many locilities, they are no more liable to suffer in this way than hogs of any other white breed. The climate of some Western and Southwestern States is unmistakably severe on white hogs, not well haired, and when such are constantly exposed to biting frosts, drying winds, and scorching sun, the results will, in most cases, be anything but satisfactory. and the balance will be found on the wrong side of the ledger.

As now bred, we cannot look upon them as a reasonably profitable hog for general use, but Suffolk boars can be used to good adrantage on many farms where white hogs are preferred, and more refinement is desired.

The Hon. John Wentworth, of Cook county, Illinois, having bred the Suffolks, exclusirely, for upwards of twenty years, owning many of the finest in the world, and being, after this long experience, an enthusiastic admirel of them, we solieited his estimate of them as a farmer's hog, and he gires the following in reply:

"After trying carefully all the other breeds, we give the preference to the Suffolks, and we think all others will who try them as long and as impartially as we have. They make the most pork with the least food, and with the least bone. They are the quietest 
logs. Give them enough to eat and they will never leave the premises. They lie down and remain so until they want more food. They make the least offil of any hogs, and they root about the least, even when short of food. For crossing upon other hogs, they have decidedly the preference. Their eross upon the largest white sows make the best of Chester Whites. 'Their crosses upon the largest black, or speckled sows, make the equals of Berkshires, Magies, Polands, Poland-Chinas, Essex, Byfield, and other darkcolored breeds.

"Indeed, with a judicious crossing of the Suffolk boar upon the ordinary cheap hogs of the country, you can closely imitate any existing breed of hogs, or make a breed of any form you please.

"It is a remarkable fact that the Chesters, Berkshires, Magies, Polands, Poland-Chinas, Essex, Byfields, etc., etc., as well as the later formed breeds that have taken the most prizes, have been manufactured in this way, from the Suffolks, which are the oldest breed known to man. Our Suffolks are well haired, and run in our pastures and barn-yards with our cattle, sheep, geese, ducks, and chickens. They are as quiet and harmless as any animals we keep. As the Suffolk is not a new breed, nor recently made up from unknown crosses, but a long-established Eng. lish variety, it is therefore a true breeder. In them there is no breeding back to the original common or made-up stock. Their litters are not part of one kind and part of another, but they are uniformly true to the Suffolk characteristics. They breed even, each pig as good as another. ***** During the season of grass they will keep fat without any other food. Suffolk pork costs less and brings more money than any other.

"Suffolks are the most popular breed in England. The Suffolk attains maturity at an early age, and may always be in a condition to kill from the time they are a month old. The carcasses command a considerable extra price over the common hogs of the country, partly on account of the greater weiglit in proportion to the bone, and partly from the pork being of better quality and flavor. It derives its well-known name, "the English noblemal's hog," from the fact that it is always in a conclition to be killed, however suddenly company comes.

"The object of the farmer is to get the most meat to the least hone, the wost valuable matter in the hog upon the same food to the least portion of the valueless matter. The Suffolk may be sinall, compared with mammoth breeds, but he contains as much that is eatable as most hogs of double his weight, and which 
consume four times his food. But the Sullolk can be made of suprrior size hy keeping ofl' its llesh until the bones are properly developed, and this development cannot take place whilst the young bones are overlalen with flesh, as those of over-fatted Suffolks are apt to be. But, owing to the.r short leigs, they weigh much more than is generally supposed. The Sufrolks never root up their pastures, nor make enemies of neighbors by wandering away from bome, or by bruaking into their premises. The Suflolks are invariably white, cxept now and tien oae will have two or three bluisin spots. These Lluish spots, on the skin, but never in the hair, mulike those found upon nuy other hogs, inclicate purity of blood and recent importation.

"We started out in 1855 with Suffolks deseended from the pe:as of Lord Wenlock and $11:$. Crisp, of England; and we ean satfely say that we have bre: from every importation into the United States and the Provinces since; and we intend to keep up our stock by importing ourselves and availing ourselves of the importations of others. We have sold Suffolks into every Stute and Territory, the Empire of Japan, the S.miwich lslands, the British Provinces, and Mexico.

"The following statement will explain how persons who amnually ship large quantities of logs to Chicago view the characteristies of the Suffolk. When we first began to breed Suffolks, and there were no railroads in the comntry, hog raisers would only buy boars and raise half-breeds to drive. As railroads approached them they would raise three-quarters blooded to drive. As railroads would reach them, and they hat little or no distance to drive, they have bought Sutlolk sows is well as bo:us, and raisea full-bloods."

Mr. Wentworth, in a communication to the "Prairie Fum:r," says :

"I rend, with great interest, the report of the committee at the late Swi.te Broeders' Association upon the characteristies of the Suftolk hogs. I have hat them exelusively for the pist cighteen years, and my sales will arorage one ham tred erery year for the past ten years, and i think I have h.del all the inportations represented in my herd.

"Wlile I commend the general correctness of the report, I wonld state that there is one characteristic that was not only not ullulel to by the committe. but it wats rather repudiated in the following words, free from spots or any other color,' Now 
there is a liability in all Suffolks in have round bluish spots upon their skins, althongl covered with white bristles, and these spots secm to increatse with age. My present boal was selected for une by Mr. Harison, Secretary of the New York State Agricultura: Society. When he arrived, aged about six nonths, he was spot less, and so continued until about two years of age, and then bluish epots of the size of an old-faslioned silver alollat commenced growing lipon him. Now, at four years of are, he has about twenty of them, although the hristles eovering them are white. Of course, these spots are exceptions, not one in ten having them, and very few insicle of one year old; yet there is a temilency to them and no liog shoulci be rejected as a pure Suflolk on their account. These spots are easily detected from black spots.

" $\Lambda$ t one of the state Fairs at Chicago, one of my boars not only took the first premium as the best Sulfolk, but the sweejstake prize as the best hoar of iny age or loreed upon the gromil. He liad several of these spots upon him at that time, although having none until he was a year old. I notice tiess bluish spots oecasionally uр) hogs at the stock yaris, which have, in all respects, claracteristies of the Suflolks.

" $\Lambda$ correspondent of yours, whilst finding fault with the size of the Suffolk, thinks they are the best for crossing upon other hogrs. I have found this to be the invariable opinion of men who want a breed of hogs of their own, independent of everybody else. Wherever they start, whatever may be their groundwork, before they get through making their new breed of hogs they invariably incorporate somewhere a eross of the Suffolk.

"Your papor says that four humcired is the profitable size of the loog. 'The Suffolks ean easily be mate to weigh this anount, by feeding them lirghty until their legs have accuired sullicient strength to support their weight of careass. The inferior weight attributed so often to Sullosks arises entirely from overfueding them whon young."

Mr. William Smith, of Detroit, Michigan, has longr ocenpied a front rank as a breeder of these loogs, and is faniliar with them and their loresding, in Fugrand, as well as America, and his testimony is this :

"Having lored the Suffolks continually for over forty years, I can safely assert that they are a great favorite with me. I find in the improved breed nothing to condemn, and everything to commend. They attin good size at an early age, and their quict, 
pleasant disposition, clenn, snow-white appearance, and handsome form, are very desirable fentures in connection with their many other goul efualities, not the lenst of which is the comparutive smitl :umount of loud they require.

"The Sullolks are mpidly graning in faver, and wherever introdued give gorsh satisfaction. T.sey mre quite harly and thrive in almost any climate that my of their species will, from the most northern part of Canade to sonthern Missonri and California. We know that they flourish and give satisfaction, as humbecls of my customers can testify.

"Canada, Michigan, New York, parts of Ohio, Indiana, Illinois, lowa, and other States, are rapidly becoming stocked with them, mul in my opinion it will not be many years before they become "the horg" of the country. There is no possible question about their being the very best thoronghbred for improving the common or mutive breeds, and for this quality aloue they would be entitled to a lront rank in the list of valuable breels."

'The Report adopted by the "National Convention of Swine Brecters" on Suffolk swine, is as follows:

"Mr. Sidney says: Yorkshire stands in the first rank as a pig bremling connty, possessing the largest white breed in England ns well as an excellent medium mol small bieed, all white, the last of which, transplanted into the south, luns figured and won prizes under the mumes of divers moblemen and gentlemen, and in more than one conaty. 'The Yorkshires are closely allied with the Cumberland breeds, and have been so nuch intermixed that, with the exception of the very largest breeds, it is difficult to tell whero the Cumberland hegins and where the Yorkshire ends. It will bo enough to sny, for the present, that the modern Manchester boar, the improved Sutholk, the improved Middlesex, the Coleshill, and the Prince Albert or Windsor, were all founded on YorkshireCumberland stork, and some of them are merely pure Yorkshires transplinted and re-christened.

Speaking of pigs kept in the elairy distriet of Cheshire, he says, ' white pigs lave not found favor with the dairymen of Cheshire, and the white ones most used are Minchester boars, another namo for the Yorkshire.Cumberland breenl.' He says, in another place, and all the authors who latve followed him, down to the latest published work on the subject, oecupy spitce in describing various comty pirs, which have long ceased to possess, if ever they possessed, any merit worthy of the attention of the brecder. Thus 
the Norfolk, the Suffolk, the Bedforl, the Cheshire, have each separate notice, not one of which, except the Suffolk, is worthy of cultivation, and the Suffolk is only another name for a small Yorkslire pig.

\section{" CHARACTERISTICS AND MARKINGS OH SULFOLKS.}

" Head small, very short; checks prominent and full; face dished ; snout small and rery short; jowl fine ; ears slıort, small, thin, "lpright, soft, and silky; neck very short and thick, the heal appearing almost as if set on front of shoulders; no arching of crest; chest wirle and deep-elbows standing out; hrisket wide but not deep; shoulders thick, rather upright, rounding outwards from top to elbow; crops wide and full; sides and flanks, long ribs, well arched out from back, good length between; slooulders and hams, flank well filled out, and coming well down at ham ; back broad, level, and straight from crest to tail, no falling off or lown at tail; hams wide and full, well rounded out, twist very wide and full all the way down; legs small and very short, standing wide apart, in sows just keeping belly from the ground; bone fine; feet small, hoofs rather sprearling; tail small, long, and tapering; skin thin, of a pinkish shade, free from color; hair fine and silky, not too thick; color of hair pale yellowish white, perfectly free from any spots or other color ; size small to medium."

Since about 1882 several gentlemen, farticularly in Eastern States, have taken much interest in what are resignated as "Sinall Yorkshires." 'They are neat little white hogs, with wonderfully short, lisher faces, and so much like the Suffolks that, some persons who raise both confoss they can scancely distinguish them apart. 'Their similarity is 80 great that, as a matter of fact, a Suffolk makes a very goorl small Yorkshire, and vice verse. 


\section{OH $A$ P'Fl VII.}

\section{THL VSELX.}

The Fises breed of swine is emmparalively molnown

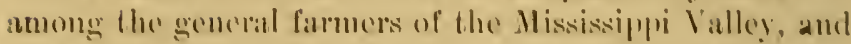
wo hate no kmowledere of their bering lativesl in ally (o)tsillerahle mumbers for pork. Nitl, in some localities, they ane hrol in a limited way-more, perhats, in Kon-

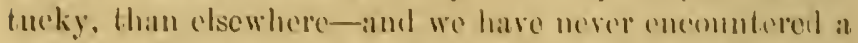
person who had ones tried them, who diel not plase at high estimate on their value as a small hored, and especially on the boars to nso for erossing on soms of laregere hreals.

Thoy seem to he essentially the same as tho sulfolls. oxcept in thoir black color, and less liability to skin discases, which womld in a majority of eases make them tho farorites over their white comperitors.

Wo think there is small probathility that the Fssex swine, as now bred, will erer heome the prevaling breed, from the fant that they are of a smallere class of hougs than most furmers care to rase, or packers to buy and handle, and we deem it imporshable that the next: fifty of one homelod yens will wilness tho rasing of smatlor swine, acurerally, than tho Berkshires, and it is more than likely that, in the futmo, the happy modium will bo an animal in sizo betwoen tho hest moldeded smallbound Berlishire and the eostres l'olame-Chinas of the present time.

Just here, perhaps, is a titting plane for remalk-ind we do so after full deliberation-that the party who ean exhibit at the next centemial Exposition any lester foediug hows, or those better suitud for general purposes than a cross bedwern the two last-mamed brecels, will have some stock to bo very prond of: 


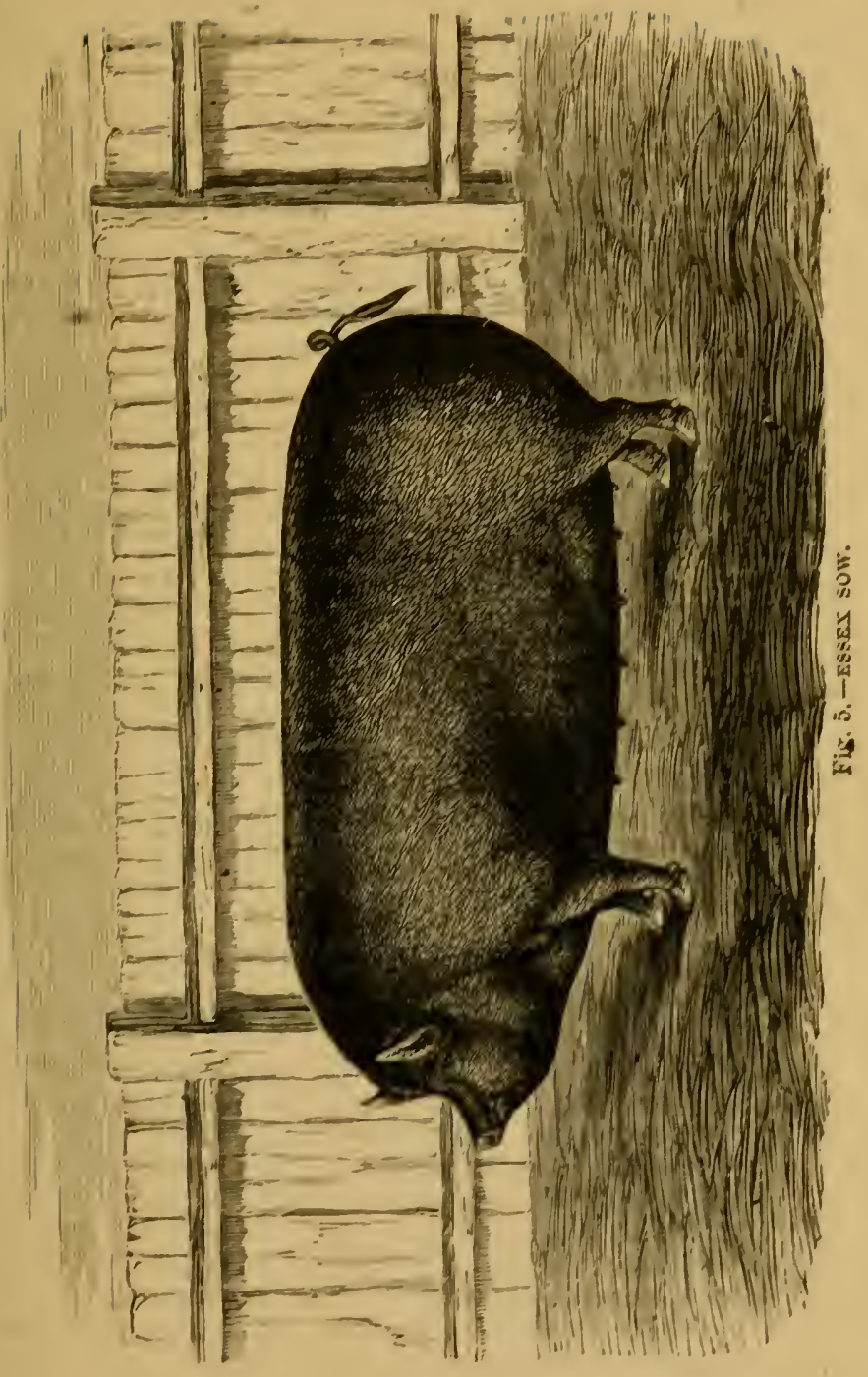




\section{Sidney's "Youatt on the Pig," (London, 1860), says :}

"Early maturity, and an excellent quality of flesh, are among the merits of the improved Essex. ***

"The defect of the improved Essex is a certain delicacy, probably arising from their southern descent, and an excessive aptitucle to fatten, which, unless carefully counteracted by exercise and diet, often diminishes the fertility of the sows, and causes difti culty in rearing the young.

"As before observed, they are invaluable as a cross, being sure to give quality and early maturity to any breed, and especially valuable when applied to a black breed, where porkers are required. For this purpose they have been extensively and successfully used, in all the black pig districts of this country, [Great Britain,] where, as well as in France and Germany, and in the United States, they have superseded the use of the imported Neapolitan and Chinese.

"Many attempts, on a limited scale, to perpetuate the breed pure, have been unsatisfactory, because it is too pure to stand in-and-in hreeding. They require much care when young.

"In the sows, the paternal fattening properties are apt to overbalance the milking qualities, and make them bad nurses. ***

"The improved Essex are ranked amongst the small breeds, and there they are most profitabie; but exceptional specimens have been exhibited at agricultural shows in the classes for large brecds."

Mr. Wm. Smith (before quoted under Suffolks) breeds the Essex extensively, near Detroit, Mich., and writes of them thus :

"This is a breed that will be appreciater in proportion as it becomes known. Their characteristics are almost identical with those of the Suffolks, except that the Suffolks are a pure white, while the Essex are a beautiful jet black. This is always the case, and any mixture of color, in either, is inadmissible. The style, form, size, disposition, and feeding qualities are similar in the improved breeds; and the pork of the Essex will dress as white as any, if rightly managed. Although they are considered one of the oldest established breeds, yet there have been frequent and marked improvements within the past fifty years, - not the least of which has been reached during the present decade.

“To Lorl IVestern, of Mark's Hall, Fssex, England, is given the credit for their first great improvement, or I might say, of being the originator of the present type, though it was much inferior to 
that of the present day. This improvement was brought about by the introduction into his herd of the Neapolitan pig-a small, fine-boned, black breed from Italy. The late Fisher Hobbs, of the same place, followed up the improvements on the Western breed, until he has made a reputation for himself and breed that is woridwide.

"Sir George Mumford Sexton and other noted breeders have succeeded in keeping them up with the advaneing times, and to-day there is no animal, of any kind, that shows finer or more perfect breeding.

"There are many black hogs in this country that are called Essex, and which may have originated from the unimproved Essex stock that was introduced a few years since, and though they may represent the name, they come far short of representing the quality of the improved breed; and as a consequence many who have lıad experience or aequaintance with the former, have but little faith in the latter, from a want of the knowleclge of the great difference between them.

"The improved Essex matures early and attains good size, often reaching from four to five hundred weight. Their meat is excellent, and, like the Suffolks, can be made fit for pork at any age, from a month upwarl. They are favorites with all breeders of them. In England there are many counties that scarcely know any other breeds than the Suffolk or Essex. They are inarketed by the thousands for light family and butchers' pork when from five to eight months, and for that purpose there are none better. They command a ligher price than the coarser pork, and the market reports always make a distinction in the quistations, and show a wide difference in the prices in favor of these breeds. * * I could find much to say about, and in praise of the Essex, but I will only add here, that they are hardy, healtly, and prolific."

Dr. Chase, of Kansas, in his description of the leading breeds, says : "We must say a word for the little Essex. They are more squarely built than the Berkshire, quict, docile animals, that fatten almost at the sight of corn, and weigh, under ordinary treatment, when full grown, from 250 to 275 pounds. As a thorough-bred stock, to breed to common sows, we do not believe they will produce as large grade animals as the Berkshire.

"For the gentleman in town, or the small farmer, we 
know of none that will give better satisfaction than the Fsex."

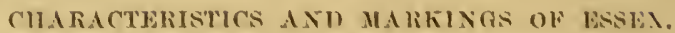

T'he report adopted by the Convention of Swine Breeders, of eharacteristies of this hreed, is as follows:

". 'l'he lissex is a blatek hog, originating in the sontle of Fuglant. 'Jliey are of small to medium in size, and are oxtensively mad in Englanel to eross on tho latre, coirse swine, to improre their fattening qualities.

"lho hest sperimens may bo known as follows : Color black: face short and dishing; ears small, soft, and stand creet while young, hut coming down somewhat, as they get age : eareass loug. bront, straight, and deep; ham heary and woll let down; bone tine; careass, when fat, composed mostly of lard : hair. ordinarily rather thin. The fattening qualities being very superior As heceders they are very prolitic, and aro fair nurses."

sine the foregoing was prepared. we hare received from Mr. W. W. Cottrell, of Cirentichl. Mich., the following. under date of Deember 15th, 1s:

"Yes: I will cheerfully give you my estimate of the Fisecx, and will premise hy saying. that during my experience in brecding and managing thoromgh-bred pigs for the past ten years. I have. some of the time. exceeded a a thousand choice animals of the improved breds, including the kssex in considerable nmbers, which has giren me an opportunity to eompare and experiment upon their relatire merits, under the same and different treatment. alomgside of each other. I also have intimate knowledge of the experience of a gentleman who has bred these pigs. with others, for the past forty years, both in this conntry and in Englanel.

"As a result of this experience, l can say that, in my cstimation, they take rank amoug the best.

"The Essex are as distinct from all other types as it is 
possible for one breed to differ from another, and still prossess the principal valuable features belonging to the species. In form, fuality, and disposition, they more nearly resemble the Suffolk than any other bresal, and, in fact, there is a similarity lesween them in this respect.

"In the improved brecel, the style, form, color, siz", disposition, and gencral characteristies, are very uniform. 'They are certainly a standard breed, and one of the oldest establisherl. Mr. William Smith, of Detroit, has been the most extensive importer and breerler of thein that I know, and they have always been favorites with him, both here send in England, where he has suceessfully competer with the most noted breeders. His thorough knowledge and experience has enabled him to give the breed a still higher value than they possesserd, even before.

"They mature carly, their rneat is execllent, and a year, at most, shonld sulfice to feerl thern to the most profitable condition for pork ; which is nne of their nerits, and when fat, the carcass should yield a large proportion of lard.

"They are invariably black; shonld have a short, dished face; soft, fine, cars when young, though with age they will bergin to grow heavier, and drone somewhat. The body should be of medium lenoth, broad, derpo and straight; with a heavy ham, well let down, and bone fine, but strong enough to support the carcesss in gord style. When in condition, the proportions should always be symmetrical and pleasing; medium, well-haired, with a fine and comparatively soft coat.

"They pussess powers of transmitting to their jurogeny an excess of their own gorel qualitires, when corsssed upon common and coarser swine, and the first corsss upen onr natives will improwe their pualities, almost beyond reseresnition. Excepting the Suffolks, there is no breed that ean compare with them for this purposc. 
"As breeders and murses, they are very fair, though not equal to the liorkshires. In fact, all thomengh-brive animals, as they heome retined, or - high bew," lessen their fermed propensities to al gereater or less extent: lout onlinarily, with good management, no serieus ditliculty neod be experiened on this point with well how Esses. It is essential. however, that the brond sows be matured. and mot premitted to berome tou fat, which hatter is often apt to be the ease, with geod ferd and treatment.

" (iend pastume, with plentro of water, will keep them in ample condition for breding. thronghout tha whole grazing solsoll. In fat, I have know them to come ont of a geod clowe tide in the fall, "hilling fat." withent

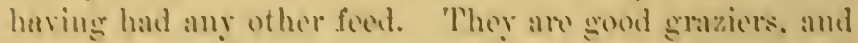
have the advantage orer some of the more temeler-skimed white henge, of being able to withstamel, (at any age, how(rer youngs) the hottest smo of duly or Angust, without having their backs or skin in the least attectol, ant they are never knewn to seald or mange.

"The young pigs of tho lissox aro nsually mote delicato than those of the cosisser brovts, and will often :prpear quite inferior to the lattere at the same age. up to vight or ten woeks, when they will hegin to shout ahead, ame 'shew their breding.' 'This is mot always the ease, but often is, and latribute it to the mothers not being smeh good milkers ats some other kinds. It seems to bo their nature to run to fat rather than milk.

"I have no trouble in suceesfully bowding my Essex, and almost invariahly tind purehasers well satistied, and theneeforth atrocentes of the bredt.

" In my opinoin, thomgh they may never become so popnlar as some, they will still bo a raluablo standare. breed." 


\section{II $\Lambda$ P I' H: R V I I I.}

\section{YORKBHIRES-CHEBIIRES, OR JEFFBRSON COUNTY SWINE, OF NEW YOIEK,-LANCASHIRES. - VIC'TO.

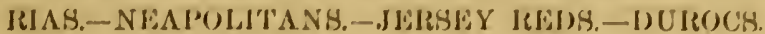

'lihe breeds of swing named above are so litile known by the general farmers of the conntry, that such merits as they have are overlonkerl and neglecterl. Unlike the: more forminent breeds, the information to be obtaincel respecting them is quites moserso.

Whe latve becu unable to find anylhinge of mureh im-

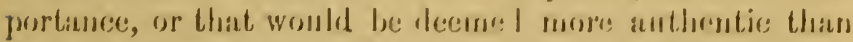

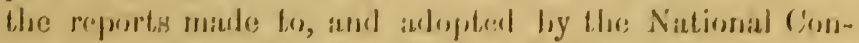

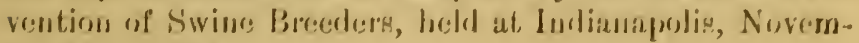
lece $201.1,18 \% \%$.

\section{Yol:15:SIII:1:S.}

We have never not in the Wresl, al, failes or elecwhere,

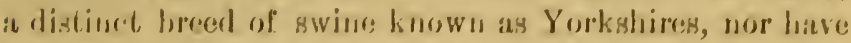
We eascorsed with any ons: having any positive prastical knowledge: of them, but submit the report on this loeed as presenterl to the Convention at Judianapolis:

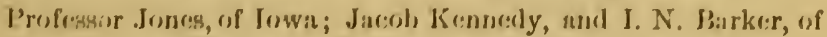

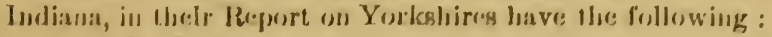

* * * "Their coslor and charucteristices laves licen traceel, in a granter or leses degree, into every popular bresel ol' swine which bas lacen made: upor atlempteal to he catahlished as thorengh-bred,

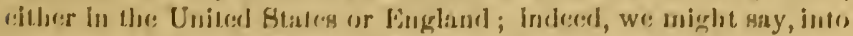

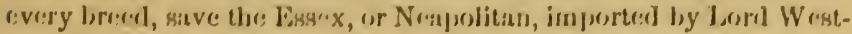

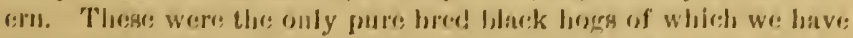

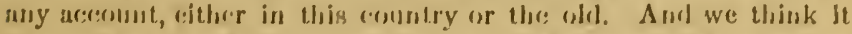
may safoly be suid of these white hoers, that they aro: the only pure:

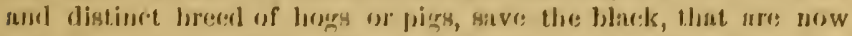
bred on this continent. J)o not understand us as contending that

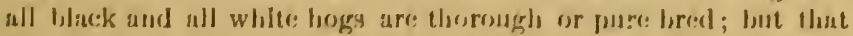
all breseds in this country of mixid collors are what their costor indicates-are mixed or cross bred, lichece not pure and distinct 


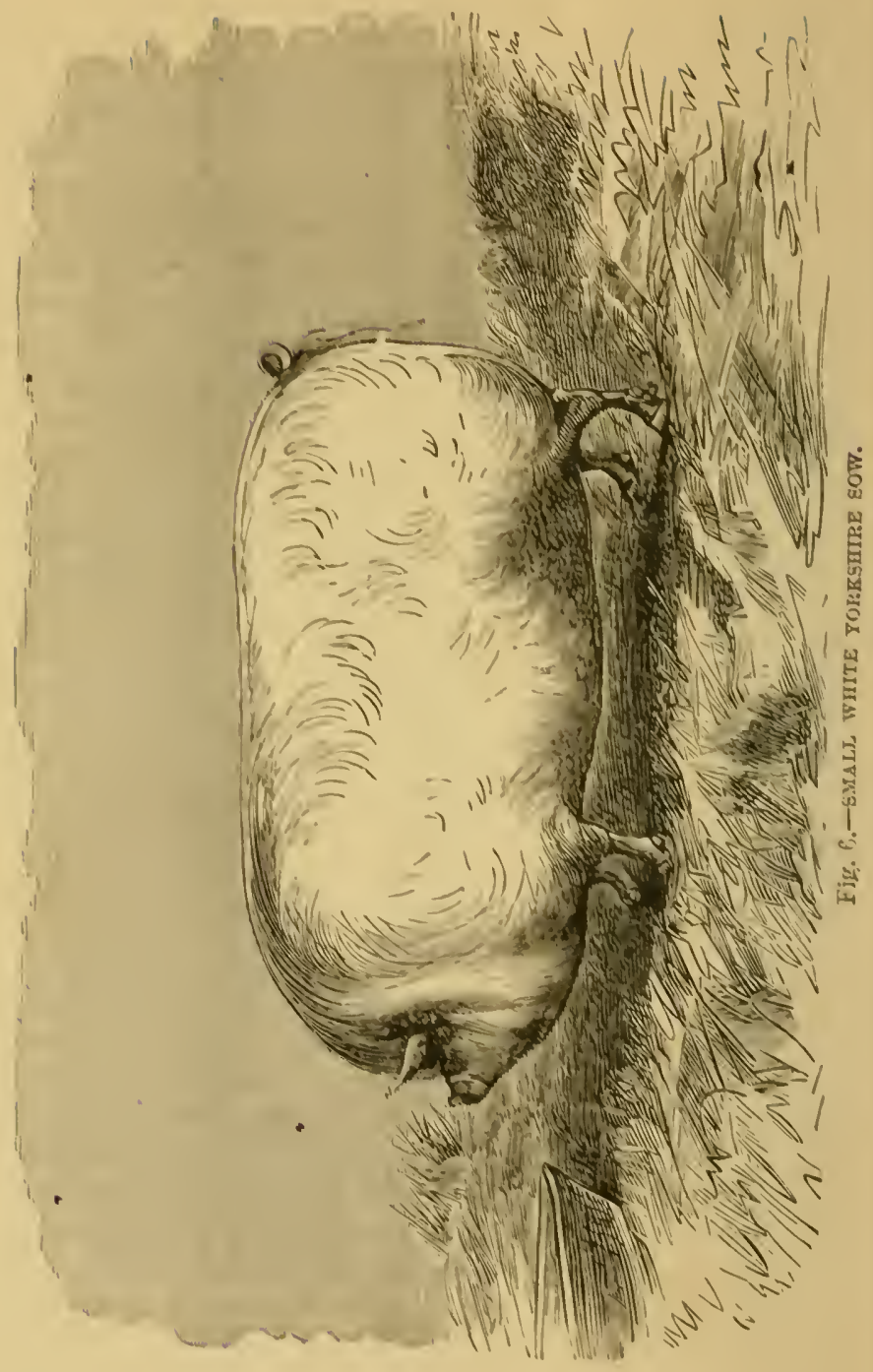




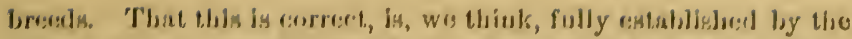

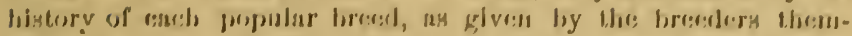

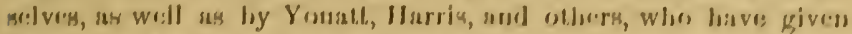

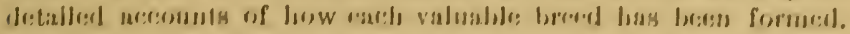

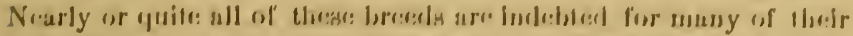

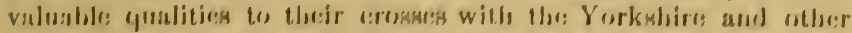

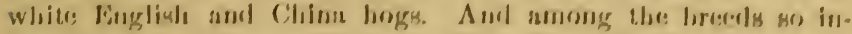

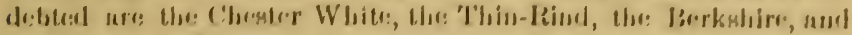

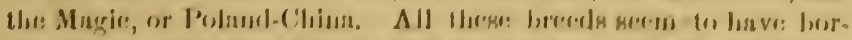

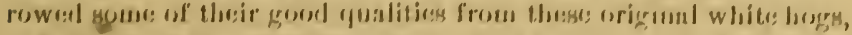

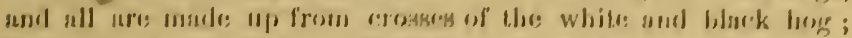

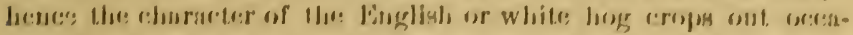

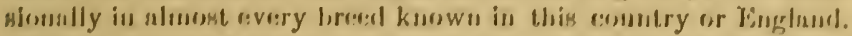

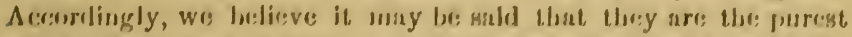

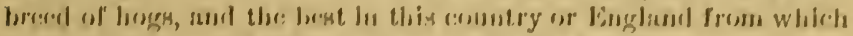

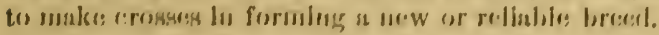

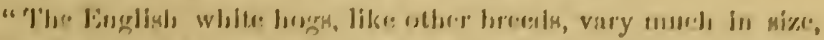

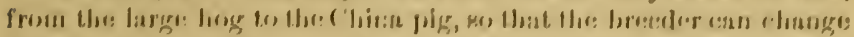

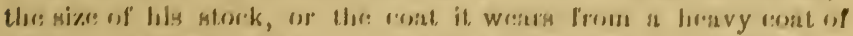

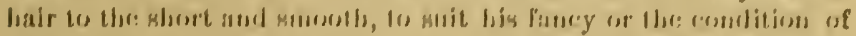

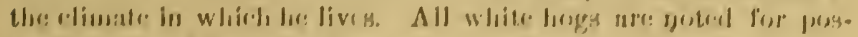

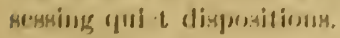

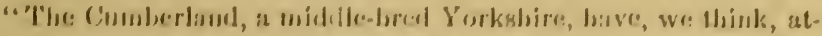

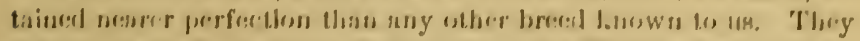

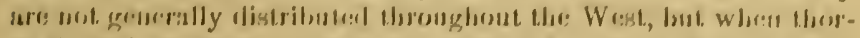

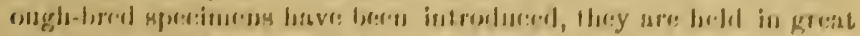

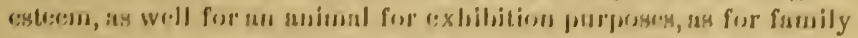

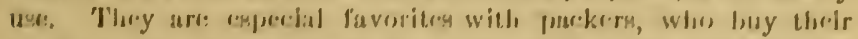

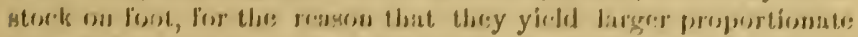

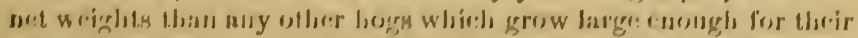

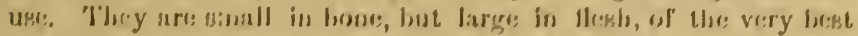

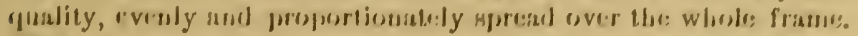

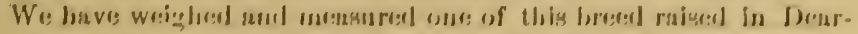

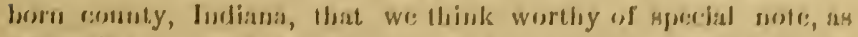

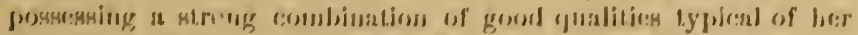

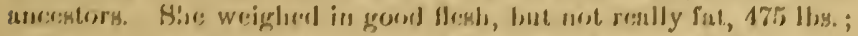

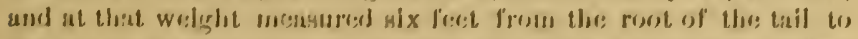

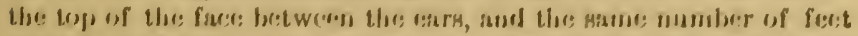

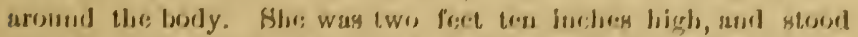

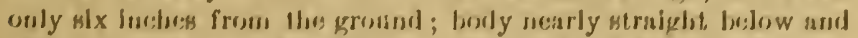

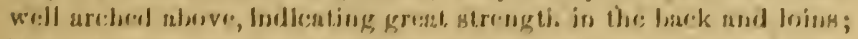

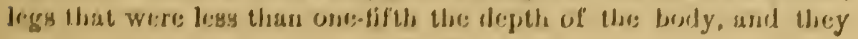


rery small, striight, and smooth, measuring below the knee but six inches in eircumference. The surface of her body, jowl, und legs, was smooth, and tree from ridges and creases, and well covered with a short, smooth cont of white hair. This, we think, might be taken as a fair description of all thorough-bred mimals of this stock. It seems to be in this comntry, as it is sail to be in England, in almost every why a middle breed. We know of no breed of hogs in this country but what might in some degree be improved by crossing ocensionally with the thorough-bred Yorkshire, which has been bred pure in this country since 1860 . We have seen whole neighborhoods and districts where the swine were nearly ull lopeared, rough-skinned, black, sandy, and spotted white or blue, where, in a few years, by introducing a few of these pure blooded white hogs, the general stock was male white, given erect enrs, and skin made smooth. Such a result cannot be attained by Chester Whites alone, but it eau be accomplished by the thorough-bred Yorkshire. They are so thorough-bred and positive that they carry their own eolor when erossed with almost any other breed, even if it is entirely black. Hence it is diflicult to find a breed of swine in this age of their improrement, in which the white Yorkshire does not erop out in some particular. And again, the pure white Yorkshire and the black Essex, or Neapolitan, may be bred together in such a way as to duplicate the color of any other breed of hogs to be found among us. And hence we elam the white Yorkshire, as now established in this country mul England, is the most thorough-hred hog known. The Yorkshires are the most valuable swine to breed from or to cross with that we have ever met with in this country; and for these reasons: 1 . They are of a size, shape, and flesh, th t are desirable for the family or the packer's use. 2. They have a hardy, vigorous constitution, and a good coat of hair protecting the skin so well, either in extrene cold or hot weather, that it rarely freezes or hlisters. 3. They ure very quiet, and gool graziers; they feed well and fatten quickly at nny are. 4. They are very prolific and good mothers, and the young never vary in color, and so little in shape that their form, when matured, may be determined in advance by an inspection of the sire and dam. This we have learned by a practical experience of many years in breeding, slaughtering, packing, and consuming.

"'The Yorkshire medium or niddle breed,' in the words of Mr. Syduer, 'is a modern invention of Yorkshire pig-breeders, and perhaps the most useful and the most popular of the white breeds, as it unites, in a striking legree, the gnod qualities of the large and the small. It has been produced by a cross of the large and 
the small York and the Cumberland, which is larger than the small York. Iike the large whites, they often haves a fow palco-blue spots on the skin, the laair on lheses sjouts loring whitr. All whifr: loreceds

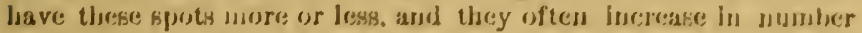
as the anitnals grow older. * * * *

"The middle Yorkshire breed are aloout the same size as the: Berkshire breed, but latve sunaller locade, and are musch lighter in the benes. Tlecy are better breeders than thes small whites, but

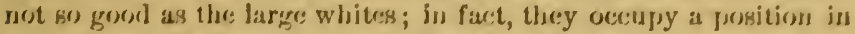
every respeset between the two breeds. Hence their size cass be increased or diminished without crossess with any other breed or color."

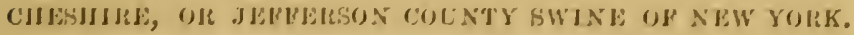

'I'le following was adopted by the Swinc Breeders' Convention, of 18:9, as the report upon this breed:

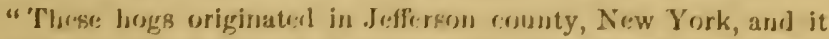
is claimed by somes of the broseders that they started frosu a pair of pigs longht of Mr. Wresllorel, of Allany, New York, which,

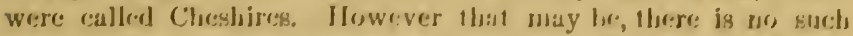

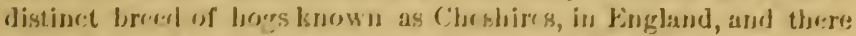
is no record of any longs of this name: laving becen inported into this consutry.

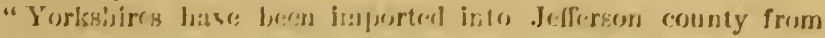

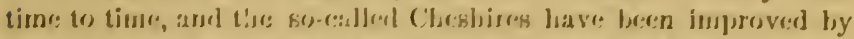
crossing with theia lest lougs longlat in Canada. Mr. A. C. Clark, of IIrislersosn, way, for a mumber of years, a jorominent breceder of

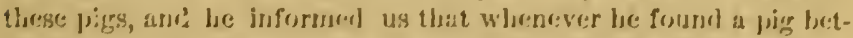
ter than these he oswerl, los purchased it and crossed it upon his own stock. In this way this family of hougs have heen produced, and they are now known and fored in many portions of the Lnited States. Their breceling in Jeffersons county has diminishes] during tha last 2 wo or tlirce yours.

"They are pure white, wills a very thin skin of pink coslor, with little bair; are not unlform in this rekpect, as pigs in the sarne lit tor differ widely in the amosunt of lair ; the snout is often long, but very slender and fins: the jowls are plump and the cars erect, fine and thin; the shoulders are wide, and the harns full; the flesh of these loges is fine-grained, and they are rommenrled on account of the extra arnosint of mess pork in poropention to the amount of oflal; the tails of the pigs frequently dres? off when poung." 
Under date of April 11th, 1s:6, Col. F. 1). Curtis (who mato the foreguing report) writes the anther: "l'here is nothing to ahlil to the report. I do not know of but one breedere of these pigs in deflerson comnty, N. Y., at the present time, who malies their breding : specialty. 'lhere was nerer al eomeeted effort to make

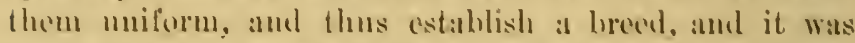
quite common, in one state, fo call any aross of lorkshires or sutfolks by the name of Cheshires.

" Mlr. Clark, as long ats he bred, bred fo a stamed:ard, and I think Mr. Gren, who is the louling brevder now, is trying to do the same thing."

Sereral breders of tinc stock, in kentucky, and some of the II estern States, have hows that are ealled Cheshires, but we are dembthul of their bing bred the same as the swine know by that name in Xew York, and the moro Fastern siates.

Knowing Mr. J. 1T. Sambers of ('hiengo, a well-hmown

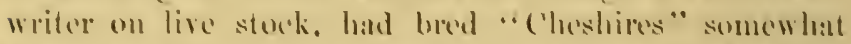
extensirely, and with suecess, in lowa. we applied to him for some anthentic information respecting them.

He replies: " In my opinion, the Cheshire is simply at derivative of the Yurlishire, ats are also the Sutfolk, I san-

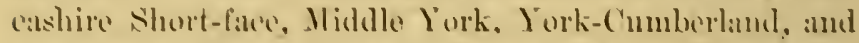
all the other linglish breeds of white hougs. I hred the si-called ('heshires for six or swen years. and twok a deep interest in notieing the variations and whanges that were frodned in that time by selection, in-breding. and erossing. Within the spsece of seren yestrs, withont introdnoing any bloed hut what was supposed to bo pmo, I produced. all the ditferent types of the Yorkshire, from the large lork, down to the laneashire short-face.

The white eolor was firmly fixed, and I never knew one of my Cheshire boars to get a pig that hate a black hair on it, althongh they wero bred to sows of all breods, including the purest Fses. Another peculiarity that I 
watehed with interest, was the frequent apposararece of blue spots in the skin of the purest and best bored apeesimons. I'his peroliarity would sometimes disappear for oneor two generations, and would again crop out stronger tlan cever.

"l'he type which I finally succeceded in fixing "pon the Cloreshires, as bred by roce, was almost identical, in size, Eorm, and quality, with the most approved inedium Berkshise. Indered, so marked was this resemblance in everything but color, that they were often facetiously called ' II'hite Berkshires.'

" $\Lambda$ s bred by me, I regarded them as mong the ver" loest of white hoog.s.

"They wrere well haired, had a very delicate pink skin, and their meat was most excullent, tender, and juicy."

\section{VIC"TOUIIAS.}

Mr. Charles Es. Toland, of Albany, New York, submitted the following report at the Convention:

"The fumily of pigs known as Victorias originated with $\mathrm{Col}$ lrank D. Curtis, Kirhy Homestesad, Charlton, Saratogn county, Now York. 'Threy were male by eremsing the lisfield hoges with ther natives, in which theres was a strain of the (irazir.r. Subsequest crossess weres mades with the Yorkshire and Suffolk; the result boing a purely white hogg, of medium size. The nane has nos significanese, unless it is intender as a compliment to thes English Quesern. Thesses pigs, if pure breed, shonld haves a direct

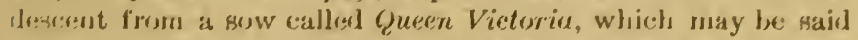
to be thes mother of the farnily. She was pronouncesl, by gorod

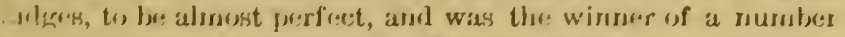
of first prizess. Browders in thes Eastern states have long felt

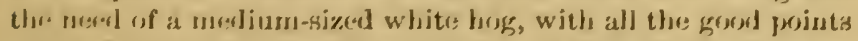
of the Finglish bowels, without their of jeetionables featuress-a bresed which would maturesearly, and be covered with a growd crat of hair to protect it from the cold in winter and the heat in surnmer. Cosl. Cortis began breeding nearly twessty years ages to try and nueset this want. At the fair of the New York State $\Lambda$ gricultural Socciety, which was heeld at Elmira, he exhitr ited a suw, Princess Alice, and six pigs, which was the first 


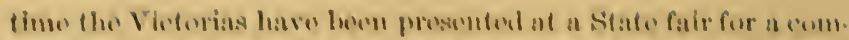

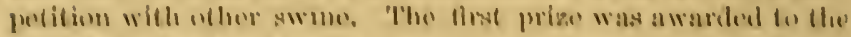

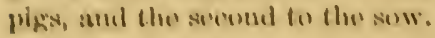

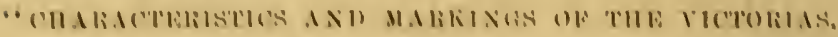

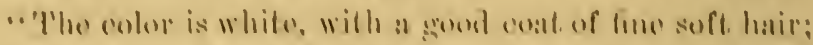

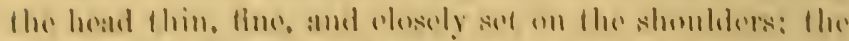

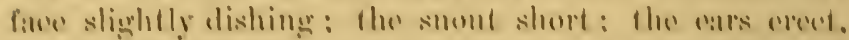

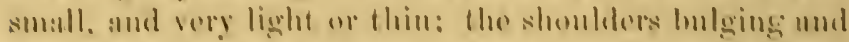

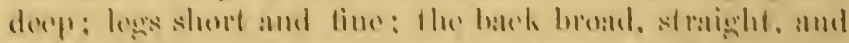

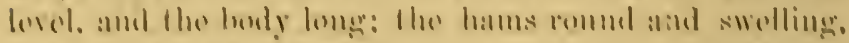

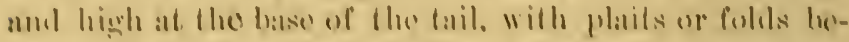
twown the thighs: the lat time, and fow from wrinkles

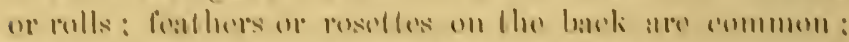

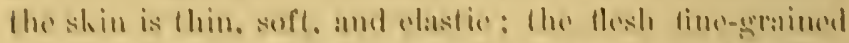

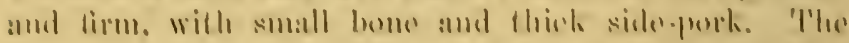

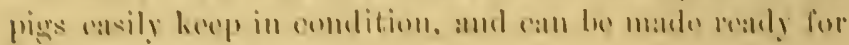

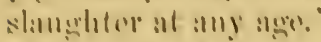

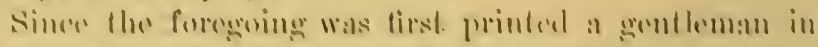

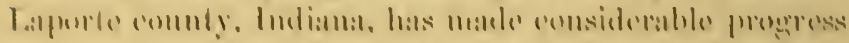

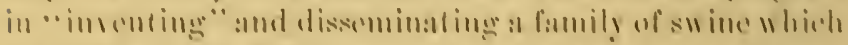

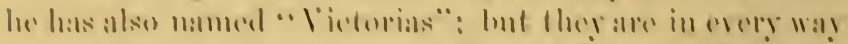

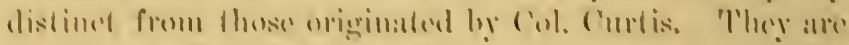

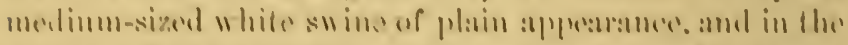

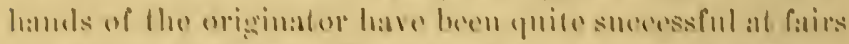

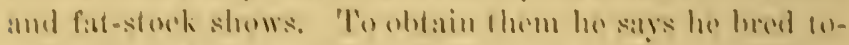

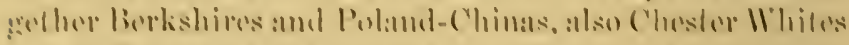

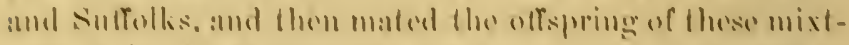

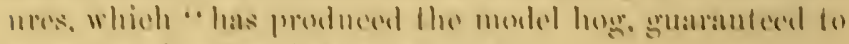
mentme itsolf whito orery timo"?

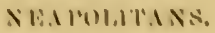

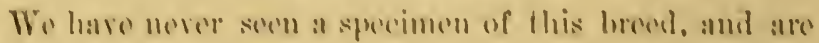

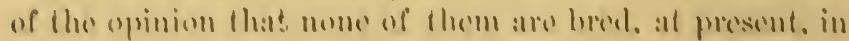

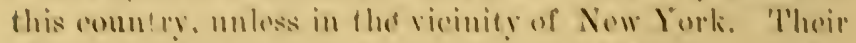

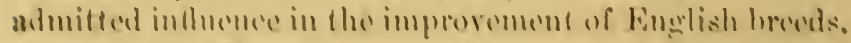

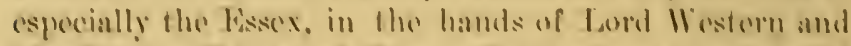

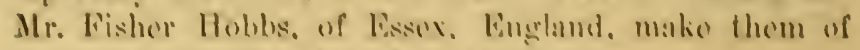
interest to fanciers of highly rotined pigs. 


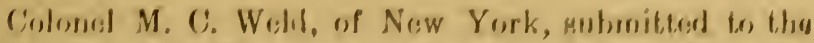

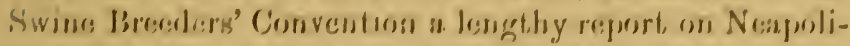

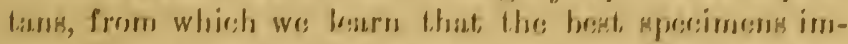

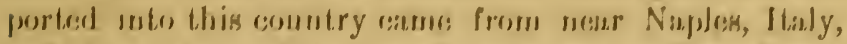
and that their carlicest introduction was hy flon, fomes (i. King, of Weschawken, N. J., in suloult 1840-11.

Some of thease were porre black, others alate-enolor, somes ansh-costored, or a dirty-whito, and othears more or loses

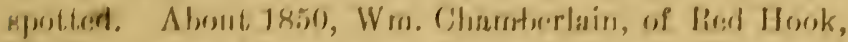

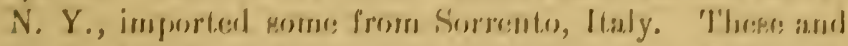

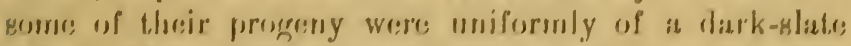
color. Other prartion, whor had traveled in thaly, and beren mench pleated with the pork of Naples and the surround-

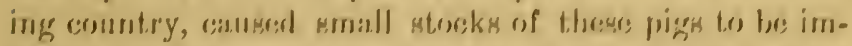

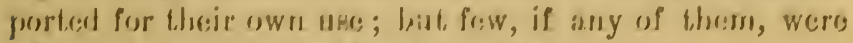
offered for malle for breseding purporases.

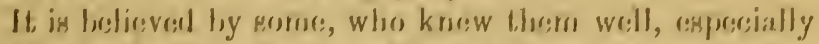
in Engrand, that, this bresed hes had an existeroco in the

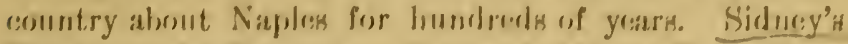

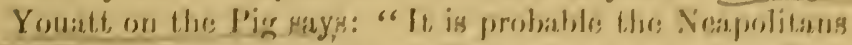
are deecendasulas of the dark lastern swine imported by

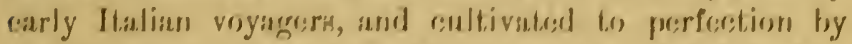

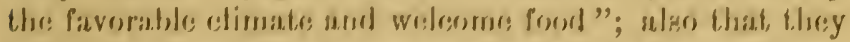
are "black, or rather brown, with no brietlege, and conserpuently delisate when first introduced into our northcril rlimitc:"

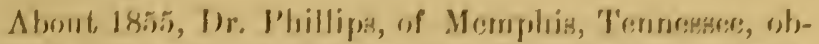

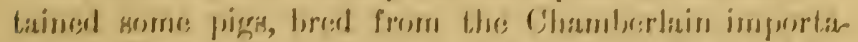
tions. Ho found them mores eatiofactory then any of the;

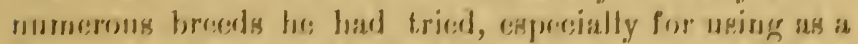

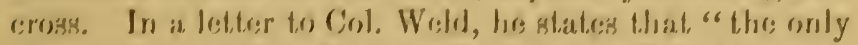

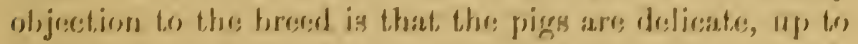

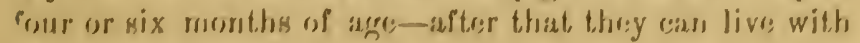
he: commerrorn hogg."

Gol. Weld has ow real them imported direct from Jtaly, and thinks the fact that these pigas are alonost hairdeds, 
has cansed their reputation for delieacy, and that, treated as a high-bred raee should be, they are not delicate, int quite the contrary, though he would not, have them fallrower in wirter, or in too elose confinement. 'Their pork is deseribed by A. B. Allen as being liko " youme, tender, fat chicken." "They are elased with the stmall hreeds.

The Conrention iddopted the following as the

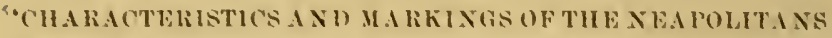

"Head small: forehead bony and flat: face slighlly dishing: smont rather long and very stender : cars smalli. thin, standing forward noarly horizontally, and quito lively: jowls very full: neek short, broat, and loiry above: trunk long. eylindrieal, and well-ribbed biach: back that, and ribs arehing. cren in low thesh ; belly horizontal on the lewer line: hindpuarters higher than the fore, but not very mueh so: legs very tine. the bones and joints being smalter than those of any other bred: hams and shoulders well developed and meity; tail fince eurler. flat at the extremity and fringed with hair on each side: general color slaty, or bluish-plum color, with a cast of coppery-red: skin soft and the, nearly free from lair. which, when found upon the sides of the heid and hehind the forelegs, is hack. and soft, and rather long: flesh firm and elastic to the tomeh."

\section{IFLSEY IIES.}

The following is from the licport of the Comvention:

"The positive origin of this f:mily of Swine is unknown. They have been bred in portions of the State of New Jersey, for upwards of fifty years, and with many farmers are considered to be a valuable variety. They are of large size and sapable of making a heavy growth. five humdred and six humared pounds weight being common. Mr. Divid ledtitt, of Salem county, N. J., has knewn of these logegs for therty years, and Mr. D. M. Brown of Windsor. fer nearly tefty years. They are new axtensively beed in the midelle and sonthern portions of sew Jersey. In some neighborhoods they are bred quite 
uniform, bring of a dark-red color, while in other sections they arr more savely, and of en patched with white. They are probaloly deserndantes from the old improtations of Berkshires, as there: is un record of the Tiamworth, the red hogg of England, cover having besen hrought, into this eountry ; nor is this likely, as tho: 'lamworth were not eonsidered a valuable hreed, and wore continerd to a limited breeding. The Reds resombles thes old Brrkshires in many respesets, but ares now much coarser than llo improverl swine of this bresed.

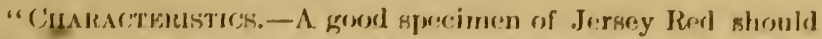
be rod in color, with a snout of morderate: length, largo Jope-eare, sinall hear in progertion to the rize and length of the borly; they should bes long in the burly, standing high and rangy un thin lege; bone: coarse ; losavy tail and brush ; Jair coarese, in. cluding the bristles on the back. They are valuables on arcount of their siz: and strong constitutum ancl capacity for growth. They are not subject to mange."

\section{DUtugs.}

These hogrs have ouly a lowal reputation, and of them Col. F. D). Conrtis repenterl to the Convention as follows:

"Thro is anotloer family of loway hoge called Durose, which are brerl in Saratoga county, No:w York, which are finer in the bone and rarease than the Rorls. They haves been bred, with their crosses, in this region of country, for about twenty yoars. Threy are very hardy, and grow to a large size."

Early in 1883 a numbel of broeders of so-called "red hrogs" met, at lilk IIorn, Wis., and formed an organizidtion to be known as the Duror; or Jersey Rerl Swine Cluk, with a view to advaner: the improvernent of the breod, and establishing a rogistry of prodigrees. 'The stamclard anged upen by the Club is as follows:

"The true Duroc or .Jersey Red should be long, quite deepbusliesl, not iound, but broaul on the: back, and bolding the width woll out to the hips and hans. The heasl shoruld bo: amall, compased with tloc brody, with tla chesek boroul and full,

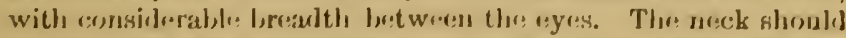

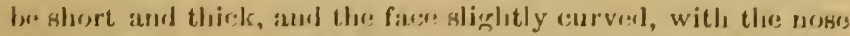
ratlerer longer than in the English loreseds; the sars raller lavge

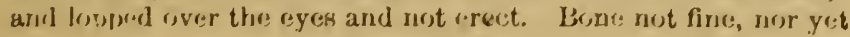


coarse, but medinm, The legs medium in size and lengeth, hut

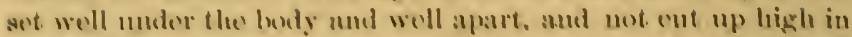

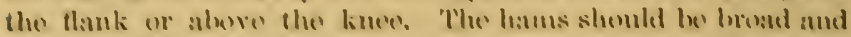

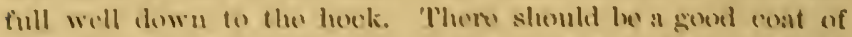
tait of medium themess, imelining to bristles at the top of the

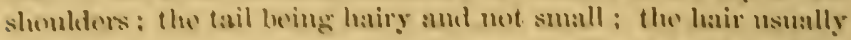

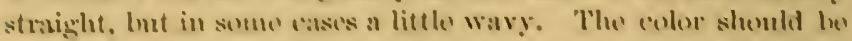

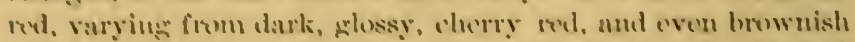

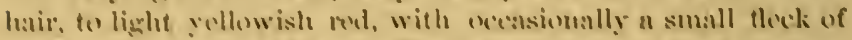
black on the belly and legs. The darkere shates of red are preforred hy mest brenders, amet this type of eoler is the mest desirable. In disposition they sme remarkably mile sme grenth.

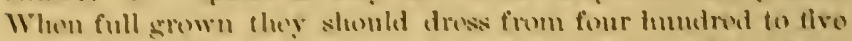

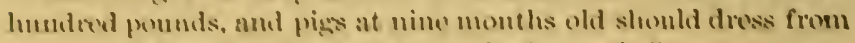
two humbird and tify to thes lombered pounds."

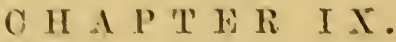

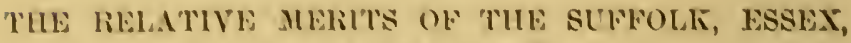 AND biRlismbi.}

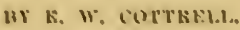

"The question is very blem usked me by persons who are desirons of procuringe sume one of the improvid breds of swine. which of these theer stamedard breds do I emsider best for the farmor, and it is a question which 1 timel dittenle to deride, even now, after quite an extensive experience of mearly six years with the the brests side by sthe. I consider, lowwerer, that there is so little actual ditteremer in the result, that fomey might guide the

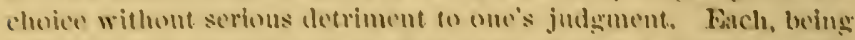
a distimet and orighinal breel, most have its own peruliarities and distimetive qualities anci the question to decide is, which of these gualicies are mest desirable, and which of the breve pessess and combine the most of them?

"Faney must devide the question of heanty and appesarance, and one personts juelyment in that respreet is as good as anetler's. Association with cither for any length of timo will generally ocession prejudice in its fincr, and either breed possesses sutlleient beaty to secure them hosts of admirers; and while I admire aliko 


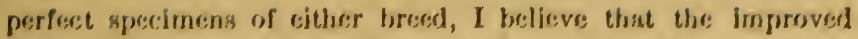
Berkshire displays a mors majestir; style arsd graceful apposarances

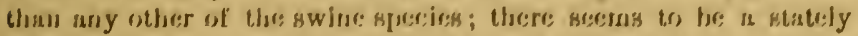

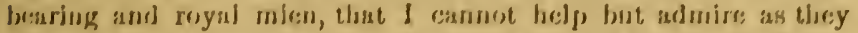

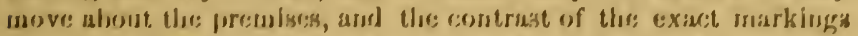

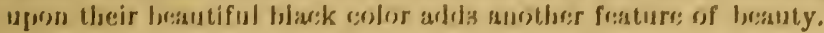

"In regared to the more cassential guestion, bowever, of relative quality und profit, I will suy that there are: several thisgen which

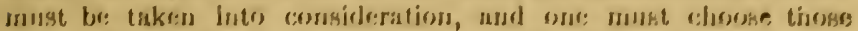

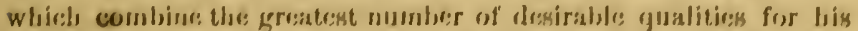

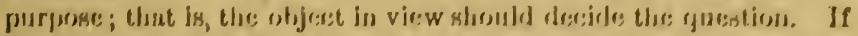

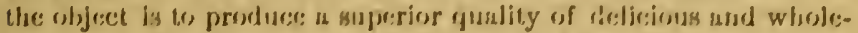

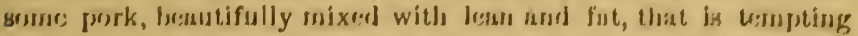

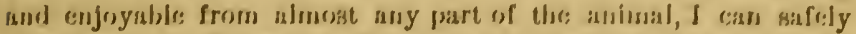

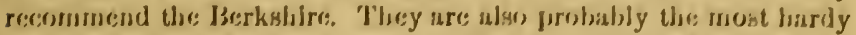
of all the improved swince specios; ; al ways lacalthy and thrifty, and

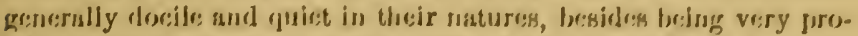

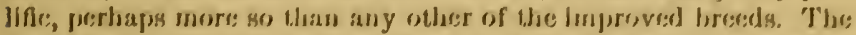
sows are invariably goorl inilkers, and goret mothers, onse of fon successfully reariog from effoth to twalve juigs.

"Thes improved also mature guite (sarly, and at right or nine montlis will give from two huredred to two bundred and flfty pounds of prork, and in many rasess much mors, witl "xtra care. At

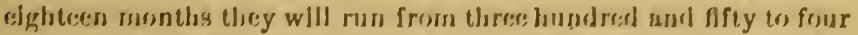
humblred and fifty pounds of pork casch. We lases had thesn woigh, at two ycars, Beven hundresl and righty pounds, and not at all coarso: or overgrown in style eithor. They are generally very uniform in

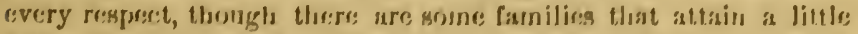

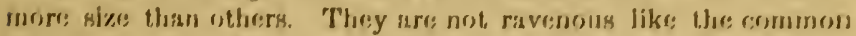

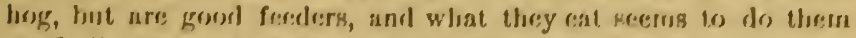
gosod all over; and, in fact, withrout disseusseing thes subjeset further, they can be briefly summed up as a bardy, forolifle, domestic, and

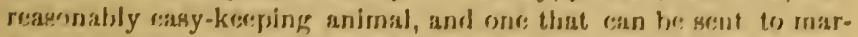
kret at almost any isge, with profit to tho: producer, and satiafaction to the consumer. Consurgusutly, in my Jurlgment, one who is undecided in bis chosice cannot go far astray in selsecting tloe Berkghisess.

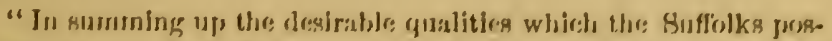

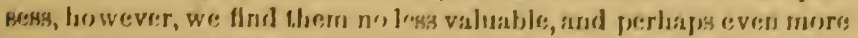
profiable, for some furpesess, than those of any other bresed, usuleses

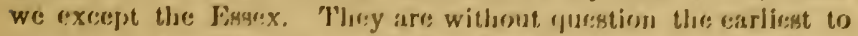
mature, take on fat morc resdily, and peoduce mors net jork with 
The same amount of foed than any other of the hog kimd. These

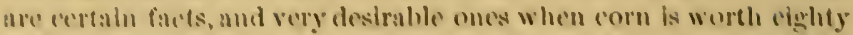

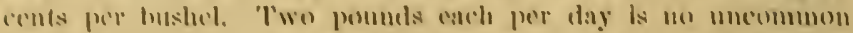

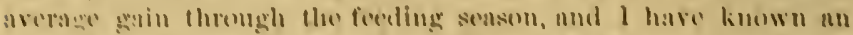

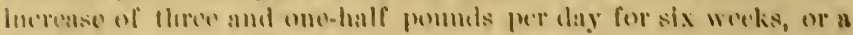

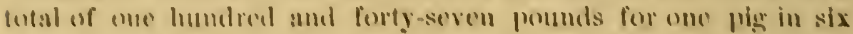
wechs time.

"And this propensity for fatteningexists from the time fley are

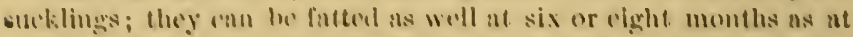

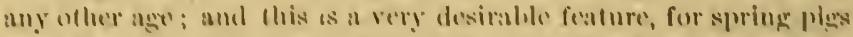

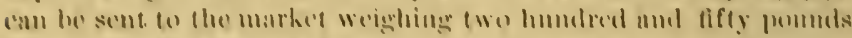

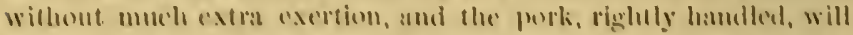

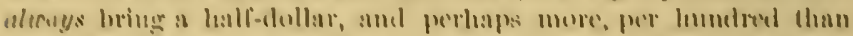
wilt llee commomer hinds: and in reality it is worth molh more to the constumer from the fare of its quality. The head and feet are alunse moninal appemelages, whilo the bones of the eareass ato so

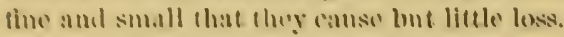

"The objection is often rased that they mo apt to lo too fat for 11se, ofe. Of eouse this is only from persons of supertleial hess. It. might as woll be sald that sugar is foc sweet, or vingur too

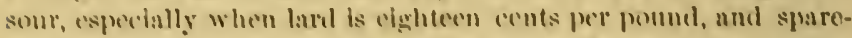
ribs and other trimmings werth only four or the esents per pound. It is the fat that attords the greatest protit, ame protit heing the objoct, the animal whieh will produes the most fat, will the lenst

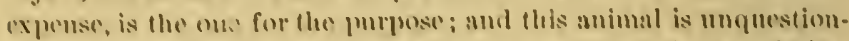
ahly the suffolls, for they do cortamly oxeed in this perolintity, particularly at an early age. Notwithstmoling the nhove facts, it shombl not be inferred that the pork is inferier as a meat for the tuhle. 'l'he mnimsl may have a surphus of fut, hut the lleshy parts

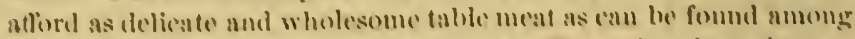
the hog kind, and certainly as delichos. The trimmings from a

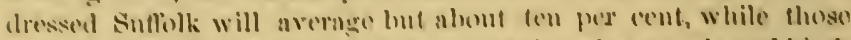

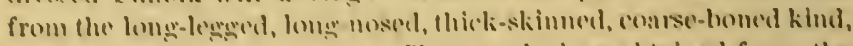
ofters make fwenty per cont. 'The comelusions obtatined from the

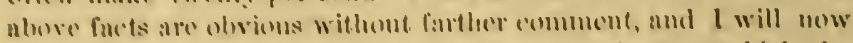
make refermese to some of the other dessirsble fentures which the Sutlibli possesses, a special one loring their docile, quet dispessition.

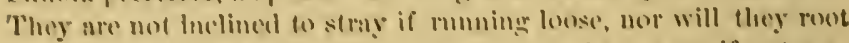

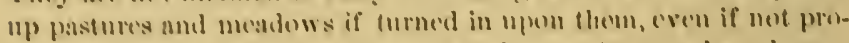

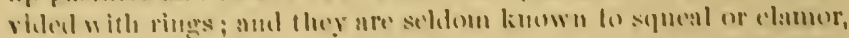
if half eared for. It is owing to thes guiet, demestio mafure that they grow and fatten so riphilly and comomically. 'Tluy also 
buve a gand coustitution, and sure invariably healthy with us, when

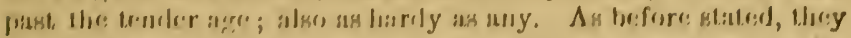

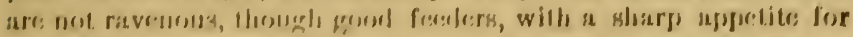
what tlory mellere. Whach fied will regularity, they will be on

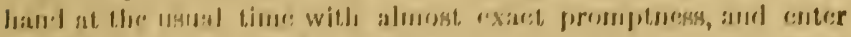

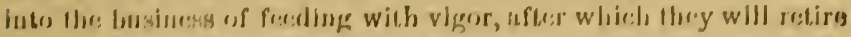

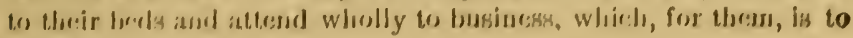
graw usul finliens.

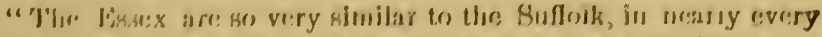

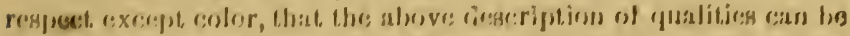

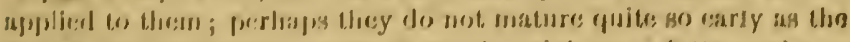

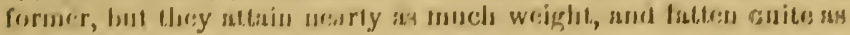

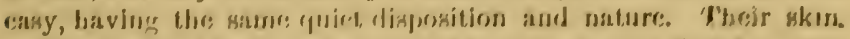

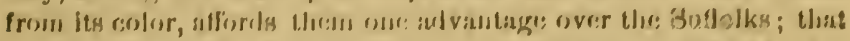
14, when the piga of the latter are: very youmg, if expesses 60 a

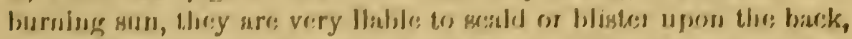

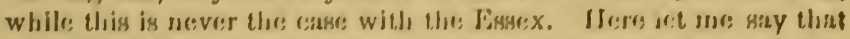

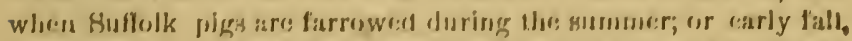

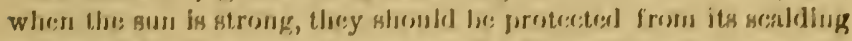

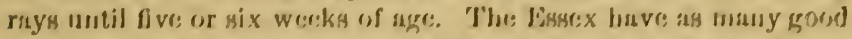

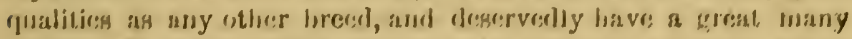

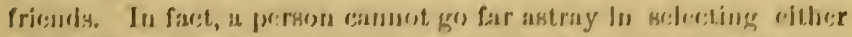

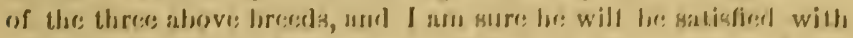
whicluever kind his fassey maly dearl him to chooses after geving tle:m " fair trial."

In wrilines of numerous experiments roacio by him, in

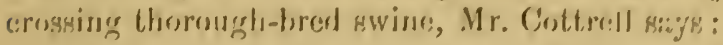

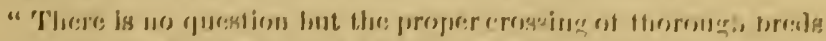

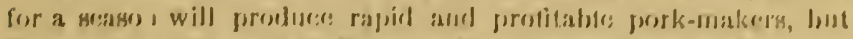

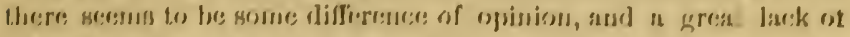

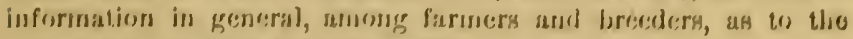

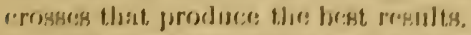

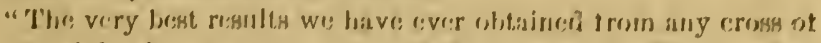
1.horrough-fureds, was that of the: Buffolk upous the: Esasex. Ono casse, which was almost a marvel, I will give for exansples. It is that of a litter which was farreseves the: 16th day of March, and

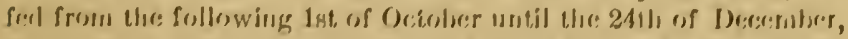

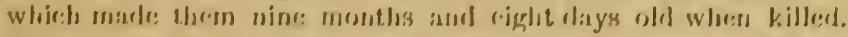

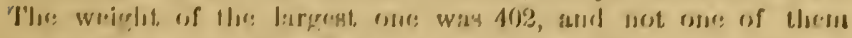

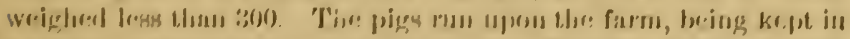

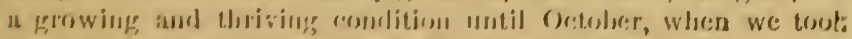
thess up and forced them along, as the sesult show 
"This marked improvement upon either breeds in the first cross is probibly the result of uniting their excellent characteristics, which seem to be more fully develeped, and stronger, than in esther originall. It is a fact, al leats, that the foeding and maturing qualities are more or less improved in the cross. Neither is the stile or beatuty ust in the cross, for the symmetry and proportion are still retainal. 'The color is generally hlack and white; some times one pig will be cither all black or all white, but usualig they are sheeted-that is, each spread in lurge patehes, aud very distuct. (t is rery seldem that we see a 'speckleci' pig amomg thoroug'. orecl crusses; there is generally a foreign mixture when they oc cur. One peculiar fenture with the color of this cross is, thit anva. riabuy the black is in excess upon the hind part of the muimal, whe the white will predominate upon its fore parts. i have secn them one-lintf pure black and the other han pure white, whth tho dividing line where the colors meet forming a circle around the body at the middle. The peeuliar marking makes quite an attrac. ive contrast.

"We also founcl that the Berkshire and bissex make an excelient eross for feeding purposes. As a principle, $\dot{i}$ do not consider it advisahle to (ross the improved Berkshure with any other, on their own aceount, but prefer rather to keep that breed listinct and np to the mark by oceasionally renewing with a foreign blood of its own kind. By foreign blood, l mean that of a distant or unrelated taml ty. They are a st:mdari bred, very near perfection in themselres, possessing qualities that camnot be very much improved upon withent atlecting the combination that constitutes the Berkshire, and stamps them with a character wholly their ow und andich only requires to be kept to the vieal of their style and nertection to satisty the requirements of almost every class, condition, and locality. The true well hred Berkslire has the stamp of the thorough-lored and possesses the merits reçuired for its purpose, and grest pains shonid be taken to perpetuate the purity of that blood. How erer, when it is necessary or advisable to cruss them, "t should bo $\mathrm{m}$ ile with the Essex, whenever practicable. The result of a singic cross will alwals gire sutisfiction, the produce being such as wil: eed quick nud mature sooner than the pure bred Berkshire, and the pork is second to mone that goes to market. The general style ano appearance of the animals will he similar, except in the markings; some will be more or less spotted, some marked like the Berkshire, some purtially marked, and some ail black. This cross, continued upon itself, wili lose its ilentity with ejthes breed, and eventually will result in a lot of mongrels. 
" Upon the common kinds the Berkshire will do much good, and bring out a great improvement, but is not equal to the Sullolk or Essex in this respect. Of course, there are other breeds which will improve the common liog, but 1 know of none to be compared to the three above mentioned, from the fact of their being pure and standard breeds, that have come down in the same line for generations, and established distinct qualities and characteristics that are transmitted from one generation to another with as much exactness and certainty as can be found in any class of the animal kind. And the fact that they are capable of stamping upon their progeny the desirabie points they possess, and reproduce thennselves, as it were, with almost a positive certainty, is what gives them such great value as improvers of our stock.

"I have said that I believe certain crosses of the thorough-breds to be superior to either of the full bloods, for feeding purposes. The question may be asked, why not continue the breeding from these crosses?

"The fact is this, as 1 have before stated, after the first cross, the identity of the breed is lost, and with it the power to transmit its particular type is correspondingly reduced, and by continuing in the same line we lose alt trace of the original. By using a thorough-lired upon the cross, of course, we produce equally as good results each time. For teeding purposes, and hy a continuation of this practice, a superior class of pork-makers will always be obtainnea.

"A na so, it one tas a number of breeding sows of the common sort, let lim procure a thorough-bred male, and $I$ will guarantec that the result of the first cross will pay an the cost. But because a lot ot very good animals has been obtained from this course, do not select your next male breeder from them, or the good already gained will be lost. But continue to use a thorough-bred male upon the produce, and those that have not tried it before will wonder at the rapid improvernent of their stock, and why they have been so long behifd the age of improvement and advance. ment." 

RAISING AND FAT'TENING SWINE. 



\section{H A P 'I' E R X.}

THE BOAR-HOW TO CHOOSE, AND HOW TO KEEP HIM.

I'o claim that suecess in swinc-breeding depends upon the proper selection of a boar, might not be wholly correct, but it is safe to say that many failures in the business have been in a large degree due to mistakes marle at the beginning in the choice of brecding animals, especially males.

However good the sows of a herd may he, the good qualitics of the stock quickly deteriorate if inferior boars are used, while, on the other hand, the offspring of inferior sows can be rapidly improved in form and quality, by using well bred boars.

It is no longer disputed by persons familiar with tho prineiples of improved breeding, that tho male parent mostly determines the outward form and structure, while the female chiefly determines the intemal structure of the offspring, a somewhat striking illustration of which is afforded in the breeding together of an ass and a mare, the produce of which isaa mule, and the mule is essentially, with slight modifieations, an ass. $\Lambda$ she ass bred to a stallion, produces the hinny, which is essentially a modified horse, the mule and the hinny each having the outward form, muscular structure, locomotive organs, and voiee of its sire.

Assuming that these premises are correct, it must ho apparent to the breeder and farmer, that the judicious selection of a boar is of prime importance, and that success is not assured in this branch of his business without it.

Among the prominent characteristics of the boar should be a fino external form, which is the result of a superior 
internal organism; a short, broad face, with round heavy under jaw, and thick, short neck, indieate strong ritality and assimilating powers, two functions requisite in every first-class, meat-producing animal; width between the fore legs, aud large girth immediately bohind them, denotes room for large and active lungs, the very foundation of any animal. libs that are long and well sprung ontward from the back, show eapacity of stomach. The broad loin and well developed ham are signs of active kidneys. A elean, fine, and elastic skin, covered with soft, lively hair, free from bristles, denotes a healthy liver, and freedom from internal fever. A fine muzzlo and limbs, clean, small joints, and standing square up on the feet, denote solidity, strength, and firmmess of the animal's framework; while the dished, or concave face, and slightly drooping ear, are nnerring signs of an easy keeper, and a quiet, contented disposition.

These are some of the features demanded in a good boar, and such an animal in perfect condition will not be sluggish and elumsy, but have a lively animated appearance, and move about freely and nimbly, unless kept in tou cluse confinement on too much fattening food.

The herd, or family of hogs from which it is designed to select a boar, should be elosely scanned, and if the animals show uniformity of breeding, good forms and constitutions, with eren feeding qualities, it is a safe one to select breeders from : on the other hand, the weedy herd, wherein no two animals are alike, should be giren a wide berth.

It is essential to choose a boar in some measure with reference to the style of females it is desired to cross him on, with a view to having deticient points in the sows corrected by the boar in the offspring. Shonld the sows be light in the ham or shoulder, the boar shonld be especinlly good there; sows inclined to be razor-backed, shonld bo bred to a boar with broad back, and well sprung ribs. If 
the sows are too coarse abont the legs, neck, head, and cars, attention shoulel be paid to securing a boar with short neck, fine ear, dish face, fine bone, and heavy jowls. If too "light and airy," too far from the ground, too active, too restless and uneasy, the opposite should be prominent characteristies of the boar. He should, in a majority of eases, be selected from a family or strain that is, and should himself be, somowhat sinallor and moro compract than animals upon which he is to be crossed, and in the swine herd, as in all domestic stock, constitution is of prime importance, and no animal without broad and deep fore-quarters has it.

He should be pure, of such breed as the owner may deen best, for if not pure, he cannot be depended on to stamp his own qualities on his offspring, as none but thorough-breds will invariably do so. 'The boar of mixed and unknown breeding is to be shunned as a snare and a delusion. If the Berkshires or a Berkshire cross is pre ferred, a pure Berkshire boar should be used. If the Essex seems most desirable, use a pure Essex boar; or if the Poland-China eross promises the best results, use a pure l'oland-China boar. Do the same with any breed that may be preferred, and suceess is certain; but to use a boar that is a mixture of several breeds, however pure they, may individually be, is to progress backward.

It is an undeniable fact, that many who pay a liberal price to olstain a boar that suits them, afterward treat him in such a way that they derive but small bencfit from the investrment. One of the two most common modes of mistreatment is, to confine him in a close pen, where he is deprived of exereise and fed upon the richest and most fattening food the establishment afforis: lack of activity and of virility are the results. 'The other mode is, to turn him with an unlimited number of sows, gilts, and stoek hogs, to fight, and fret, and tease, until he becomes tho shabl,iest, the most ungainly, unthrifty hog on the place. 
Either of these extremes must be aroided, and a moro rational method pursued, or the best results cemunot be secured. While too elose confinement is bad, it is not so bad as to allow a boar to roam at will among the other hogs of a farm, where he is as much out of place as a stallion would be if turned loose with a herd of horses. He should be kept in a comfortable pen, with a lot or pasture adjoining, and supplied with a variety of nutritious food, which means something more than dry eorn, with an oceasional drink of diluted dish-water. His condition should always be that of thrift, and vigorous health, not too fit, nor yet so lean that as a barrow ho would be considered untit for pork. If too fitt, he will be elumsy, slow, and in no wiso a sure getter. As to the age at which bo should begin serviee, we hare, after con. siderablo observation and experience, come to the eonclusion that it is unwise to permit the boar to be with a sow at all until at least soven months old, and then only in exeeptional eases and very sparingly. Immature sires camnot be expected to generate rigorous progeny. At a year old, moderate serviee will not injure him, and properly kept. he should be at his best as a sire, when from eighteen months to five years old, when he is matured and developed, and has every advantage over in half-grown immature pig ; the fuest, strongest litters are invariably obtained from large old sows, bred to aged boars.

Wo well understand that it is of little nse to recommend farmers, who raise or purehise fine boar pigs, to keep them mutil a year and a half or two years old, before using them, as not one in ten thousand would do so, yet those who properly keep their boars that length of time, will find the ralue of their brecling greatly enhaneed. Aged boars are generally looked upon as mpleasint animals to keep, especially if they have become vicions and disposed to use their tusks-a view in which the suthor himselt, shares somewhat-but they are certainly less dau- 
gerons and troublesome than the gentlest bull or stallion, while, of course, none of them are desirable, or intended for, houschold pots or door-yard onmaments.

A pen or fence sufficiently high and strong to restrain the other lasgrs of the farm, carnnot be denender on to kecen the loan in. his place, and of opportunity offers, he will soen beeone unruly; consequently, it is much the best to kecp him, from the first, in an enclosure which will afford hiir no practice in the art of loreaking out.

If his quarters are isolaterl from those of other hoggs, especiallif sows, and sow pigs-some of which are likely to be in heat most of the time-he will usually be quict and gentle, - in fact, a pretly well behaved hog, though much depends upon his natural disposition, and more upon the treatment given him.

With a fair cliance, some of the first litters will enahle his owner to julge of his merits as a sire, which, if satisfactory, will make it worth while to keep him for several seasons. Unless certain of doing very much better, we would not hesitate to loreed him to his own pigs, even though we consider indiscriminate in-and-in loreeding as reprehensible in the extreme. We advise even this cross, only when the parents are both healthy, and it is desired to fix and retain in the offspring certain points, or qualities, that are of great value, and jrominent in both boar and sow. 'I'urned with a sow in heat until one service is giren, she will have as many, and as good pigs as there would be if the boar was permitterl to chase and worry her for three days anc' nights. 'The most experienced breeders concede this, and many will not allow but a single service.

It is safo to say that the bulk of the hog erop is produced by farmers who breed less rather than over a dozen sows, on an average, at any one season of the year. 'T'o keep a matured bosir in the best eondition, is felt to be quite an expense by one man who has but a few sows, and 
where three or fomr farmers live in proximity to each other. we think it molh the best and cheapest plan for them to jointly own and kiop ono strietly sood hoar, iustead of each kepping, wholly at his own expense, mo that he thinks will do, thomer not so goext as he would like, if the tirst cost. and subsegurent expenso and tromble wore less.

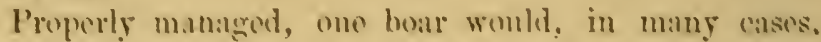

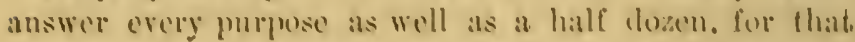
number of swall farmers, and if his cost ame heep wero sharod by all, it womled seareely be folt, amd at the samo time the fomptation to use some momgerl, or immature pig. would be remored.

Among the benetits resulting from thes method womlet be. the use of a good boar, matmed, and fitted for aroud service : an improved class of pigs, amel a goneroms riratiry, oncomaging oath of his owners to kecp a bettere grmdo ot sows, moder improred and more protituble enditions.

In sparsely settled noighhorhoods, or where too many sows were to be brod, it womld not bo so praticable: lomt whero possible. it would ho a littlo of that much-talkint-of "coïpration among farmers." which, when really practised. as well as preached, will indeed ho found and of the touchstones of suecess.

Irhen the timo arrives for him to ho superseded as tho heat of the herd, and it is desiod to make him a harrow, it. ean bo domo by ono actiro man operating as follows: After drawing up ono hind logr, and fastoning it securely to a post, or statie, fisten another ropo aromed the uppere jaw. back to the tusks, draw it tightly. and fasten it to another stake; in this position the animal sam other mo serions resistance. The ent shomld ho low down, and as small as possiblo: the low ent will atrorel a reaty means of escape for all extramems matter, anel allow the womm

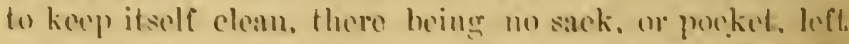
to hold the pus formed during the healing proess. It 
is not hest to perform this operation when the hoar is very fat, or the weather loo warm, ats the risk is much b) oater. If castrated early in the season, and kept on bs siss during the summer, the flesh, when he is made fat, will he but little mere rink than that of other hogr. Kept with other hogs, if entarrelsome, there is danger of his doing them great injury with his lusks, and henee it is desirable to fatten a stag loog loy himself. It is at, this period that the old boar's trae proportions will show thernselves, as he will take on fat very rapidly, and preont, a greatly improved spearance; but when sold, the inyer will quite probat.ly insist on paying for the "stag" only two-thirds the price of other hogs, which, in many casc8, wo have considered entirely too great a deduction.

\section{O II A P T F R X I.}

\section{THE SOW AND HER PIGS.}

The measure of suscess altained by those who rase hoges, depends in no small degree upon the judicions selection, for lirceding purposes, of sows that are best calculated, in their form, and general make up, to give hirth (o), and to nourish for several weeks, a reasonable number of well-formed, thrifty, vigorous piggs. The sow is the laloratery, wherein are developer the germs of the future herd, and, other things being equal, it is plain that this lahoratory, or, if we may so call it, this machine-shop, must, to furnish the hest results, be as nour perfection as possible. Sho should le selected from a stro:k, or farnily, in which fortility is a characteristic; for this essential quality is herolitary, though lacking in mumerous atrains of tho varions breeds. I'ho most promising pig at six 
or eight weeks, may fall far short of being so promising at six or elght months; and, for this reason, where it is practicable, it is better to defer the selection of sows for breeding purposes, until they have made considerable growth, and exhibit prominently certain characteristics which they should possess, and enable the breeder to form a more nearly correct judgment as to what their forms will be when they have matured.

At this time, she should appear to be of a form known as "rangy," $i$. e., the opposite of compact, of loose and open build, long, yet quite broad on the back, with short neck and head, fine ear, heary jowl-sure indications of an easy keeper, wide between the fore legs, deep sides, and heavy hams, well let down on the gambrel joint. She should be large and roomy, (in some respects rather the opposite of the boar), from healthy stock, a greedy feeder, and of great vitality, as indicated by large girth back of the fore legs, and a robust appearance generally. Coarseness is allowable in the sow, much more than in the boar, especially if she has great room for carrying a large litter, with indications of being a good suckler, as shown by having at least twelve prominent, well developed teats, or "dugs." The renerable Paschall Morris, of Philadelphia, one of the oldest and most intelligent breeders and improvers of swine in the United States, wrote: "I have always fonnd that a hog with a dish-face, short nose, small head, and wide between the eyes, is an easy, quiet feeder. On the other hand, a long, large head, indicates, in a general way, a hard, uneasy feeder, and a great consumer."

Sows, well kept, will, in some cases, come in heat when not more than three months old; but, in all such cases, care should be taken to keep them separated from, or out of reach of, any boar pigs on the place. Eight montlis is as young as it is judieious or proper to breed them, and we would much prefer to have them a year old before 
letting to the boar. In all breeds, and especially those noted for early maturity, the vitality of the young animal is taxed to its utmost in making a rapid and vigorous growth, and to impose upon it, at the same period, the further burden of production, tends to make a failure of both. The sow not being matured, it is unnatural to expect the perfection in the offspring that the dam may possess; nature is, at the same time, perfecting the undeveloped mother, and promoting the growth of the young, and the result is, that both are losers, and deficient at maturity, and the mother can never recover from this division and deficit of nature's work.

A comparison of the litters from matured sows, with those of others, that were mere pigs themselves when bred, will furnish a practical illustration of this; the pigs from the large old sows, will be more in number, and frequently double the size of the others, at a month old; and with the same care, they will not unfrequently weigh 50 per cent. more, at nine or twelve months old. For this reason, sows that have proven themselves extra valuable as breeders and sucklers, shonld be retained as amons the prized animals of the farm.

Those who pursue the plan of obtaining but one litter from a sow, and then converting her into pork, can never compete for size, style, and vigor, with those who raise stock from rigorous sows, from eighteen months to six years old.

Usually, when not with pig, or suckling, a sow will be in heat about three days out of twenty-one, or once in three weeks, and when she is to be bred, she should be free from fever, her system cooled and cleansed by a variety of food and loosening slops.

There can be no doubt that many valuable sows have been ntterly ruined for breeding purposes, by over-feeding on corn and meal, which, alone, possess too much heatproducing and too little bone and muscle-forming mate- 
rial to supply the needs of the animal economy. On this account, sows should not be allowed to run with fattening hogs kept on corn, but in pasture, and allowed a plenty of slop, made of equal parts of shorts, corn meal, and wheat bran.

The main crop of pigs should come in the warm days of April, and that it may be so, sows should be bred as near the midille of December as may be ; though in the States not too far north, and where the best of care can be furnished at farrowing time, December 1st is not toc, early for old sows, and December 10th for young sows. Old sows will earry their pigs 112 or possibly 115 days, and young sows will sometimes farrow their first litter in from 100 to 106 days from the date of serviee.

It is generally believed anong breeders, that a sow turned to the boar on the first symptoms of heat, will have mostly sow pigs, and that if she is not served until the period of heat is about passed, she will have mostly boar pigs.

While carrying her pigs, plenty of exercise, generous supplies of not too rich food, witl comfortable quarters, are indispensable to suecess, and must not be orerlooked. To allow sows to run among eattle, horses, or colts, exposes them in various ways to injuries that may cause the loss of valuable litters, especially if the sows are heary and awkward.

It is bad policy to have sows fat at the time of taking the boar, as there are few eases in which a sow, thin in flesh, approaching to leanness, at that time, does not do better than one that is fat, or in what is ealled respectable show condition. After getting with pig, a sow fattens very readily, and if fed too much strong food, is likely to become pork-fat, have smaller pigs, and do badly in farrowing.

As the time approaches for the pigs to appear, the sow should be separated from any other hogs, and placed in a 
sheitered, yet sunny pen, provided with some short hay or straw, out of which she will arrange her nest. If given a large quantity of ledding, she will make her nest too deep, forming a sort of pit, into which the pigs will roll, and surely be crushed. A shallow nest is much the best, and many fine pigs, sometimes even whole litters, have been lost by giring the sow a too generous supply of bedding material. In warm weather, but little, if any, need be given, and in cold weather, the nest should be thoroughly protected on the outside, and made so comfortable that a great pile of hay or straw will not be neeessary to prevent the pigs from becoming chilled. About six or eight inches from the floor, and the same distance from the sides of the pen, near the nest, a seantling, rail, or pole, should be fastened ; this will prevent the sow from crushing the little pigs between herself and the wall.

$A$ sow well fed at the time of pigging, will usually lie more quietly, and endanger her pigs less by frequently getting up and lying down, than a hungry one. Sometimes young or small sows appear to be in so much misery, that they cannot be quiet, but if they have been petted and kindly treated, they will allow an attendant to remore the pigs as fast as they come, which may be the means of saving many of them that might otherwise be erushed or trampled to death.

Many good farmers have been aggrarated beyond measure, by finding a favorite brood-sow in the act of destroying her litter of choice pigs, and none but those who have had such bitter experience, can realize how discouraging it is. My ideas on this subject are so nearly identical with those of Mr. A. C. Moore, the well-known breeder of Poland-Chinas, that I will use his own language to express them :

"The first losses of our litters are enorinous. By improper care of the sow, and unsuitable places and surroundings for littering, many persons yearly sacrifice their gains in swine growing. Cos- 
honrs, but not allowed to become too sour before feeding and consider it as near perfection in the way of a sueca. lent, nutritious mess, for a sow suckling a number of greedy, growing pigs.

fior the first weeks of a pig's life, the mother's milk is its drink as well as food, and therefore, in caring for suck. ling sows, it shonld be the aim ta so feed them, that the largest possible quantity of milk, of mly medium richness, will be furnished, instead of a limiter supply of that which is extremely rich, the latter being less healthfui, and more liable to cause fever, cough, constipation, and unsatisfactory growth.

Girass, or other green food, is not to be omitted from the bill of fare, and lied Clover is the standard green cerop for swine, though Blue Ciruss (I'on pratensis) is by some comsidered jurferable, but either is most excellent. It is difficult to satisfactorily manage the pasturing of several sows with pigs in the same lield, on account of the larerer pigs stealing from, and robbing the smaller ones of their share of milk, eausing them to become stunted and very uneven in size. I'le only remedy is to sepsate them.

When pigs are three weels old, they will usually begrin to eat, if suitable food is p':teed where they can get it, and a small trough should be placed in a part of the pen or lot, inaccessible to the sow, and into this abont three or four times a day, for several days, a litsle sweet milk car. bo poured-whatever t'jey will drink up elean, but not more, incrasing the quantity as they grow older, when some shelled corn, soskm in water twenty-four hours, orr more, should be given, and, if envenient, sour milk, corn-meal mush, scalded bras with ghorts, asd such nourisluing ford as will make them a healthful varicty.

Mr. Moore, before quoted in this chapter, has probably handled with suecess as many pigs as any man licing, and gives in his swine Journal the following as his method of fecding them : 
"My mode of feeding young pigs is to provide suffcient board floor, sheltered from the hot sun and the storms, on which to place the feed troughs. In these I feed shelled corn, soaked in barrels sunk in the ground, or bins; corn is soaked from 24 to 48 hours, owing to the weather. With the water that has soaked the corn, I make up a slop of ground oats and corn, mixed with bran and shorts from the mill. This slop, and the coln, is distributed to all the troughs, by means of buckets-those for the corn having holes in the bottom, to allow escape of water. From the troughs where the pigs are fed, I exclude the sows by means of bars that will let the pigs pass in and out of the trough, yard, or pen. I feed the sows on an adjoining lloor, in similar troughs. Thus, pigs that are weaned, and such as are yet suckling, but large enough to take care of themselves, are fed from the sime troughs. Of course, my jounger pigs, from two to four weeks old, are fed in the stye with the sow-have a separate trough if necessary, and are not turned into a herd until they know their dam, and will suckle only at home; but with all the time and care we can give to the "training" of young pigs, there will be some thieres in the yards who will steal from another dam when they can get a good chance.

"All feed troughs must have strips nailed across the top, to partition off the feeding room of each pig. * * * In feeding, each pirg must hare a fair chance for its share; you should not pour swil. into one end of a trough and calculate that a portion of four pigs will get their supply from the other end. Notice, and you will see that the big ones are always near the spout or first end-thcy have learned where the best swill is to be had, while the pigs at the further end-the little ones-are compelled to take the leavings as it runs to them, and are thus made themselres into "leavings." Pigs should never be fed on the ground when it is dusty or mudly

"Though I have no doubt but that cooked or steamed food will amply pay for the cost and labor of preparation, I have never used it."

While believing that they should have as much corn as they will eat, it is rery essential to their rapid growth, that other and softer food be supplied, making a variety that will be easily digested, and assist to keep their appetites sharp.

The boar pigs may be castrated when from two to eight weeks old, that they may recover from its effects before weaning time, and at that age, if help is not at hand, it 
can easily be done by a single person after a little practice. With the pig standing on his head in a nail kegr, or something of similar size and shape, which confines him so closely as to prevent much troublesono resistance, the opsation inay be easily performed. If flies are troublesome, it is well to pour sums kerosene into and over the wound. $\Lambda$ preparation sold in the markets as "Frazer's Axle Grease," is an excellent salve for these and similar wound.s and soles on any kind of stock, but if flies are not about, we do not use eren this, and nevor had a pig die or do badly from being castrated.

Sows should be spayed when somewhat older, say at three months, and there are probably a thousand men who can do a tolerible job at castrating a boar, to one that is competent to proprrly spay a sow; unless it can be done by a perion understanding it, it is risky business. We have seen an ignoramus ruin a herd of lierkshiro shotes by spaying them in the belly in sucli a manner that, when thry healed up, their bellies dragged on the ground.

Considerable observation leads us to the conclusion, that the only proper place to spay is in the side, and not there, unless by an expert. Where there is a probability of doing, or having it done successfully, we think it extremely desirable, as no hogs keep easier, or fatten better, than sows that have been properly spayed. (The reader will find this subject treated by one of the most suecessful and practicil reterinary surgeons in the country, in the succeeding chapter.)

Weaning is a severe ordeal to many pigs, but thoso cared for, and taught to eat some weeks before, do not, as a rule, appear to have their growth noticeably checked, while others, that have depended entirely on the mother's milk, seem to have their growth entirely suspended, sometimes for many weeks.

As to the proper time for weaning, the owner must, to 
some cxtent. be goromed by surromeding circumstances. Sometimes it is me'essily to wasm when the pigns are tivo or six werks olel, and in ofleer eases there may ho no partientar reasums fur doing so mutil tem, or sometimes twolro

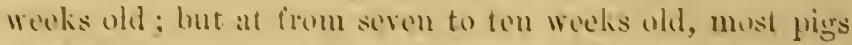
ale tit to be put away from the soms. If they eamot be successfully wommed at that ane, it is dillicult to say when

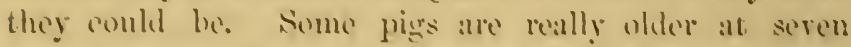
werks tham ofhers at tom. amd are hetter titted for we:ming.

Nothing is so well ealembated to make them grom as : bountiful supply of sow's milk, and the pirss that have at plenty of other ferd, with the milk of a woll-slopped sow, for vight or ten weeks, will imsariably have much tho stant in growth of those weamed at firo or six wows, no matere how much ford and atfontion the carlice womed pigs mily hase had.

If from the tomblem of a som to enet too fat. of from other amses, sho is bod the thime or fomth elay atter

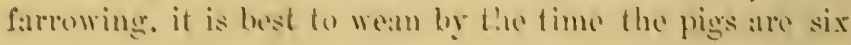

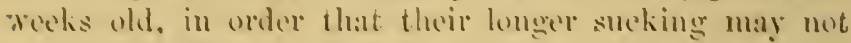
injurously athoet the suecording litter. If they have been

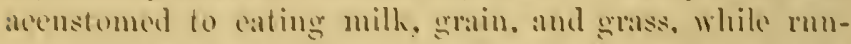
ning with the sow. this an be elone without preeptibly choking their growth: hut othowise. the sudden ahamge not infrequenty retaris it for sereral works. It shomled not he forgottem. that with swine, sts with all ofther stock. warmth is to a cortain ontent cyuivalent to food, for which reason comfordable shelter and chan, dry bedilng. have a momer value, as with these, they not only consmmo less ford, lont grom much faster.

'The sow, in most cases, will take the hoar from the second to the fomrth day from farmones. and if she is not serred then. or fails to get with pir. sho will not, as a general thing. breod again mutil the pigs hare been weaned from two to fom werks-if not too much suckled down, in about three woeks. 
It is not a good plan to take all the pigs from the sow, unlegs one or two of them san be torned with her some: hours after, to draw ont the milk she will have at, that tirnc, and again, say after a lapso of twenty-four lours. 'The wily preferred by us is, to leave about two of the smallest with her for four of five days, and after that, leave only one for two or three days more, by which time the llow of milk will have been so gradually diminished, that no injury will result to the sow by kecping them cutircly away from her.

$\Lambda$ fter woining pigs, the jasture is a gorol place for the sow, and if a mess of good slop is grven her once a day, it will be feet to goosel arlvantares: Whon bred agrain, shes should be fo fed and carrol loor, as to gain something in flesh every day, and yet not become loaded down with fat

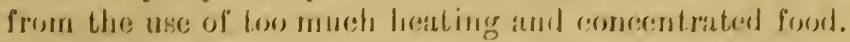
If 1 reated in a friondly waty, slos will be friendly and well disposed, and ordinarily rone as ureal paying richly for all she gets, as any animal kejut on the farmo

\section{() II $\Lambda$ I' I' I: I X X I I.}

\section{CAETRATING ANI) SPAYING.}

The nocessity of castrating the boar jign, for pork-roaking jurposes, is generally arlmitterl, but the importance of spaying such sow jigg, rn the farm or in the lichd, as are not designed for lorecders, lias never been appreciated as it should, or as it is likely to be, when the rearing of swine is condncted on sach business principles as its importance dernands. Opers sows, running with other stock hogs, are a sourec of groat annoyance, and where moro than two or theec are kept, there is scarcely a time when 
some one of their number is not in heat, and continnally chasing the others, thus keeping them in a worried, ferered condition, extremely prejudicial to growth or fattening.

If all are neatly trimmed, this is aroided, the hogs are quict and restful, and much time, trouble, and feed are salvel.

All feeders agree, that no amimals in the swine-herd feed more kindly and profitably, than spayed sows. and there are no buyers who woulid not as soom, or sooner. have them tham hamows. when they womld not buy a lot of open sows at any price. An open sow, when fat, of the same dimensions extermally as a spayed sow or barrow, generally weighs from ton to twenty pounds less.

'lo the fecler, the huyer, or the buteher. mispayed sows are usually, in one way or amother, a cheat, as they may weigh more than they are worth by having a litter of pigs in them, or maly be utterly destitute of insile fat, from having recently suckled pigs : in eithere case they are of less value than their appearanee would indicate. Spaycel sows are not tromblesome to their mates, are als good as they look for feeding or marketing and command in all markets such prices as are paid for none but first-elass stock.

'There is no subject comnected with the live stock interests, upon which so little has heen written, or upon which it seoms so dillicult to get reliable information or directions, as this. In view of this want, we have hat the following practical and explicit directions prepared by one of the most experiencel and sucessful reterinary surge ms in the comnty. Thr. 'I. C. Miles, of Charleston, Illinois. whose pratice in this branch of his profession is rery extensive. Doet. ir. silys :

"As to the lime for castrating boars. I would sas, do it whenerer most convenient. and the best uay is the way understood by erery old firmer, muless the hog is rup- 
ta:cd, in which case the striffen around the seed (called the scrotal sack) shonld be taken out with the seed, and the seed-string tied within the neck of the scrotal sack with a small twine. When this is done, cut off the seedsick, and all behind the tie, and let the hog go. I do not like sewirg up, as large tumors sometimes result from so doing. Sirould maggots develop in the gash where a hog has been cut, apply either turpentine or butter-milk.

\section{"TO CASTRATE A RIDGLING HOG.}

"In a ridgling Jog, the seeds are not in a scrotal sack, or in their proper place, bnt in the body of the animal, immeliately behina the kidneys.

"IIe should be eut in the sile, the same as in spaying a sow, but the incisior. should be made of sufficient size to admit the whole hind, when the seeds can be found and easily pulled ont.

\section{"TO AL'AY SOW'S.}

"One man should be in tho pen to eatch, and two to loold the sow, by the feet alone, flat on the ground on her right side, and stretehed ont tishtly. 'The spayer, kneeling at the sow's back, will cut the hair off of the place where the incision is to be mate, (a little back of the last ib, and about midway up and down); then cut a gashif on a hundred-pound shote, abont half an inch deep ind three inches long, up and lown; blip the flesh back cach way, about an inch, making a round gash or wide incision; then turn the knife, and stick the blacle straight in, gently, deep enough to go through the peritoneal lining, or inside striffen, at the upper corner of the incision. Then put the left fore-finger in, and with it and the right fore-finger, tear the hole large enough to allow working room for the fingers ; feel inside near the back, with the first two fingers of the left hand, for the 'pride,' a little knotty lump, which cannot be mistaken, for there are no others like it within reach, but if it is not found- 
as is sometimes the ease, then feel for small guts, called the 'pig-bag,' and take them ont the best you can, until the first 'pride' is reachel ; take this off ; follow back down the pig-bed to a fork where two guts coming together form a larger one, as two branches ruming together form a creek; here tike up the other brauch until the lower 'pride' is reached; take it off, put the pig-bed back in good order, and see that it is all in the belly proper, and not left at the gash.

"Slack up the upjer hind leg, so as to elose the gash, and sew up with two stitches, taking good hold, but going only skin-deep; one stiteh neur the middle of the'gash, the other abore it; draw the edges together, so as to tonch from the middle of the gash upward. Both stitehes may ba taken before tying either, and then tie the threats or twine, crossing each other, in the form of a letter $\mathbf{I}$, and when the sow is let go, press the luand over the gash as she starts off.

"For spaying purposes, the thread or twine used should not be too hirsh or too tightly twisted."

\section{H A P T E R X I I I.}

\section{PASTURE AND SUMMER FOOD.}

The necessity of providing swine with summer pasture and green food, is, even in the best corn-prodncing districts, becoming more and more aplanent, and it is, unquestionably, an important factor to be taken into consideration in comnestion with the economical production of pork.

So much is this the case that we cun safely say, that no fammer is prepared to raise hogs in any considerablo numbers, unless provided with pasture and grass lands, 
in which abundant water and shade are accessible at all times; with such, hogs will thrive and grow, with but little or no grain, from early spring until the new crop of corn is fit for use, and the process of fattening should begin.

This liberty of pasture, afforls the growing animals that exereise neeessary to health and proper development, and the succulent grasses, rich in muscle and bone-forming materials, are loosening and cooling to the system, tend to keep it free from disease, and counteract the heating and feverish properties of corn. $\Lambda$ very important consideration in favor of grass and forage for swine in summer, is its comparatively small cost; as compared with grain-fecling, the expense is merely nominal.

The loss that oceurs every year to farmers, from their not realizing and acting upon the fact that the hog is, in in his normal condition, a grass-cating animal, is simply enormons, and it is well settled in the minds of all who have carefully studier the subject, that to keep swine wholly upon the more concentrated and heating foods, is as unnatural and unprofitable as it would be to keep horses or cows in the same manner.

A very interesting experiment in feeding some pigs, and one which illustrates this point, was recently made by the editor of the National Live Stock. Journal. From a desire to satisfy himself as to whether a portion of grass, or fibrous food, fed in connection with corn meal, was not more healthful and profitable than the meal without other admixture, he made the experiment of which lie thus speaks :

"Taking a litter of six pigs, five weeks old, we divided them into two lots, as nearly equal in weight and thrift as could be lone with the eye. This was on the 1st of June. One lot of three way put into a pen, and fed upon corn meal soaked in water twelve hours, ad libitum. The other lot was put into a pen alongside, and fed upon green clover, cut short by a straw-cutter, and mixed with corn meal. At first only one quart of this cut clover was fed each 
pig, with all the meal they would eat. This meal, being mixed with clower, the particles were separated, and when eaten, went into the stomach in a spongy condition, so that the gastric juico could penetrate the mass as water a sponge. The gastric juico came in contact with every part of the mass at once, and the tiges. tion was soon accouplished. This lot of pigs, with the clever anel meal, were always lively, always realy for their foed; whilst the other let, with meal alone, ate greedily for a time, then became mincing and dainty for a few days, showing a fererish state of the system, contenting themsetres for a few meals with water, and ly fasting got over it, and weut on eating again. This was repeated many times during the tive months that the experiment lasted. At the cul of the time the two lots were weighed. The lot fed on: meal alone, weighed $1 \mathrm{io}$ lbs. each; the other lot, 2tolhs. ench, of 40 per cent. more for being treated as grass-eating animals. Each lot consumed the same amount of meal. The elover, in this case, was given in small quantity, and intended merely to furnish a dirisor for the meal. "The amount never execeded two quarts of cut clover at a fecl. We have since fed pigs this way, in summer, giving all the ent clover they would eat. This will be found the best way to feed pigs where it is ineonvenient to give them a run in pa-ture. They have always been healthy under this treatment, which we eall the normal ration-errass alone, or grass and grain mixel. But larger growth will he made by feeding a small portion of oil meal, mingled with the corn meal and grass: the oil meal being rich in nitrogen and phosphate of lime, to grow the muscle and bone, giring a larger growth to the frame, and thus making more pounds of pork in a given time.

"In order further to test this matter of feeding fibrous food with grain, we experimented, in winter, with two lots of pigs, two in cach lot. Each lot weighed $150 \mathrm{lbs}$. at commencement of experiment, and were all of the same age. The trial continued one humbed and twenty days. One lot was fel corn meal, wet up with hut water, and allowed to stand for a few hours. The other lot was fod a litte short-cut clover hay and corn meal, wet uy with hot water aud allowed to stand. In this case, also, each lot consumed about the same quantily of corm meal. The pigs on meal alone were healthicr than those in the other experiments, as they were older, and the weather being cold, were not so feverish. This lot gained $110 \mathrm{lbs}$. per head, and the lot on elover hay and meal gaiued 143 lbs, each, or 30 per cent morc.

"There is, no doubt, a great loss every year, to the farmes, for 
not treating the pig as a grasss-euting animal, and giving him his normal ration."

It seems to be an unquestionable fact, that tic reason why many fail to realize what they might from their swine herds, is that they devote their time and attention almost entiruly to the coln field, and utterly ignore the necessity for, or value of, pasture and green food in the summer scason. In their cagerness to eceure an alundance of winter and fattening food, they fail to encourage rapis growth upon health ful and incxpensive food in the most fivorable months of the year.

Various estimates and tables liave been prepared by scientific men, to show the amount of nutritive material an acre of land will produce, in cercals and grass, and a fair averare of their conclusions on the sulject is slown in the following table: 'The estimate of the prorluct of an acre of clover is quite low, as, when well matured, an acre can, in s. favorable scason, be marle to yield more than the amount liere given. 'Tlie table is on the basis that foir pounds of the raw material will make one pound of pork, except that for clover, fifteen pounds is allowed for a pound of pork.

Crross Provluct yer acre. No. busle.

Wheat.............

Barley.............35

Oats...........40

Corn ................40

P'eas..............

Grcen cluver....... fi tons 12,000
Prork per acre.

lלs.

25:;

420

320

5,80

375

800
Irulue, at 4 cls. per ll.

84.00

16.80

13.20

22.40)

15.00

32.00

If this is true in practice, it is evident tlat an acre of clover is worth, for pork-making, as much as $3^{2} / 2$ acres of average wheat, almost as much as $1 \frac{1}{2}$ acre of good com, and nearly as much as $2^{3} / 2$ acres of goorl oats. Hogs that have made most of their growth on corn, have stomaclis too smull to be the most successful grass-feeders, or make large gains on bulky food of any sort. Swine that are expected to make the most gain on a 
grass dict, shomld proviomsly be allowed a portion of food sullicioutly bulky to proporly distend thoir stomatehs, withomt, which they will lack earyying room.

Hon pastumes, in July ame dugust, if the weather is quite iry, alre likely to beemo short of forage, and much

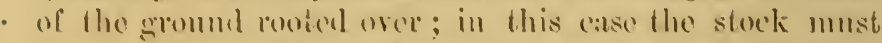

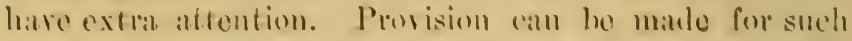

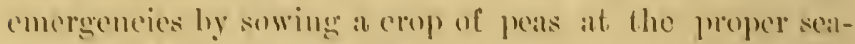
soll, and for swine in wam woither, there are fow hinds of foul exual to peas. T'wo lushels, sown broaleast on

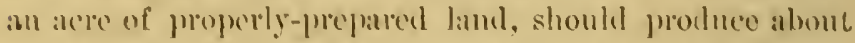
thirty hushels of shelled peas, which the hogs will harvest, and if not to ripe, liss, pods, vines, and all, will bo caten.

The value of fice lichl por is not known or appreciated by the wostorn farmers as it shomle he. and as it is likely will be, in tho fumbe : they probluce more flesh in proportim to fat than corm, and alo tit. for use at, a season when esperially merled. In bunlame, where it is impossible to ratise entu, farmers rely latracly an peas to fatten their pork: while in Canada, where very fair eorn is rased, they claim that more hog fool oan be provided from an aceo of peas than from an are of eom.

We are of the opinion that the time is near at hand. wheli an important foul for swine is to be furished in tho Ierusalem Artichole: sometimes ealled the Brazilian Artichoke, an ineorrect mame. as the plant is not known in Brazil. While hut littlo information has been given to the publie as to tho hest variety, ar mamner of producing them, they are helet in high estimation ly thoso who have given them a livir trial.

Mr. A. C. IVilliams, of Vinton. Iowa, a rery prominent and successful lureceler of Polanel-Chinas, in largo mmmbers, says:

"The kecp of my lrogs, in warm weather, is Blue grass, Clover, and Brazilian Articholes. Forty heat of hogs, and their pigs, 
may be kept willout other fond on an are of Artichokes, from the time frost is sut of the ground until the first of June, and from September, or October, until the ground is again frowen.

"To grow them, the grouncl should he rich, plowed eight or ten inclues deepe, the tubers cut same as seed potatoes, and planterl from early spring to June 10th, ten to fifteen inches apart, in rows that anc three feret apart, with six bushels of seed to the acrs.

"They rean also los planterl in the fall, from Octolser 15th to Noveinber 15th, but the tubers slsould not be cut, and the ground should be throughly rolled after planting.

"If planted in spring, plenty of rain in July and August will make them large cenrugh to turn hrogs on in Septernber, otherwise not until a month later. If in foul ground, they inay, when three or four inches ligh, be given a thorough working with caltivators, and when the hogs have been removel, to allow as new otop of tubers to grow, the ground slousld be made smorth hy harrowing, that the tops may be cut will a mower, as foot for horses and cattle.

"Enomgh seed will remain in the ground for another erop, but they can sasily be craclicatcol by mowing off the topes and plowing the ground deeply in July and the rarly part of August.

"Tlue Brazilian Artichoke is red, does not sprearl and sentter like the wild, white variety, and jorerluces more hesefecerl to the: acres than any cropp I an acruluinted with, and tho lorega will harvest the crop themselves.

"IIngs taken from the artichoke pastureg to rover aud blucgrass, will not ront up, the sorl, as they are frec from intestinal worms, constipation, incligestion, and fever, causcd by feeding corn in winter."

'The editor of the Stock.Journal, writingrof Mr. Williams' horga, as seen at the Jowa Stato Jair of 18\%f, saicl :

"Mr. Williams, of Vinton, had on exluhition one of the largest displays of Polaurl-Chinas we have ever seen on any fair ground from a single indivirlual. Nr. W. captured the first prize on sowa over ons: year and under six montlos, and the secernol on a pair of pigs muder six mowths, in a ring of 28 entries, and a reconmended herl premium. Mr. Willians informerl us that his lord was taken off his pastures and artichoke fickls without any jrevions 'fixing 11 p."

Considering how the majority of jocmium hogs and pigs aro fampered and " fixed ul" before they are taken 
to Stato liars, this is a rory high compliment to $\mathrm{Mr}$. Williams" "keep." A gontloman writing to tho Prairio fiarmer from Wakurusa, Kiansis, speaks of artichokes as follows :

"The Jernsalem Artichoke, in this State, forms a largo tuher, (those of over a pound in weight heing nothing unusual), is wouderfully productive, very mutritions, and is well liked hy the hogse, cren in a raw stutc.

"I planted a few last year to raiso seed for this senson; ame in digging them I foumd thut they hat talien cutire possession of the gromud, so that I had to dig 11 sill the ground hetween the rows as woll as between the hills, and the largest and tinest tubers wero foumd deep down in the compact sub-soil where the plow had never res:ched.

"Here I am reminded of the only olyjection (so-called) that I hatve crer hearl ureed agninst the artichoke; which is, that if they onco get iuto a piece of ground they never ean he cradicated. This, instead of being a valid objection, is really one of the strongest arguments in faror of its use for the purposo undel consideration.

"I thtnk that in secding hog pastures to the artichoke, a division fenee should be run through the middle, so that one half conld rest each aldernate year, and not he disturbed during the growing seatson. Enough, in suy event, would bo left in the ground for seed, but in this way the tubers wonld have a better chance to mature.

"In selecting a piece of ground for hon pisture, (if intended to he planted with artichokes), it will ho best to take a rich, moist soil, though they will grow in any soil that is suitathe for peratoes. Having made the selection with due eare and forethenght, let that piece be dedieated forever to the artichoke, when it will he seen that the impossibility of its cradiration hecomes its highest recommendation, for no further labor will ever be required in planting, cultivating, or digung; the swine will have plenty of the best of summer food, und they reill cultivets it smat dig it themsiless."

The following, to the same jomrnal, was from an Illinois correspomitent:

"I hare ratised the Jernsalem Arlicloke on my placo twelro years. Soil the same as the common prairies of lowa and lllinois, and my experience proves them to be a very valnable and useful crop. All kinds of steck, horses, entlle, sheep, and hogs, and chickens, are fond of them, I regarl them as rery hablity fond, and 
neessary in adrlition to grain, in the spring, and at this time, are feedin's then to my milel cows with the best results.

"One can commenes using them in September, ansl frosn thence (o) Junc, but to 1ase: them when the ground is froyen solid, they must be antlowed and beaped, and eovered with straw and earth, otlock-

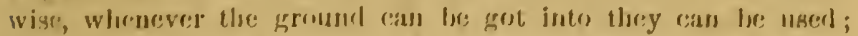

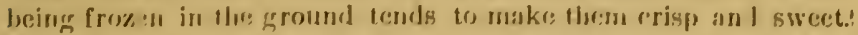
Plenty of artioliokes and a little corn luings the hoges out fine: in the spring, and they will dig then thesuselves, and will do the: saune: in the fall.

"I was warned hy my ueighloors, when I got them, to bork out or they would get my farm, and take, my place to its ruin, lut this has not been my experience. I always eorsoled myself that if they got the advantages of one and grew spontaneosusly, the straggle would be between then and weeds, the difference leing, the articloseses would have rosts at the bottom, and the weeds notlingo. The only difliculty has leeen to keop a sufliciency of roots leyond the reach of loggs, (n) renew my crop with. Cultivate sane as postatoes, aud sasne anomint of socel, will yield five to one of potatres, with sanc culture, and are inuch easicer fo cultivate, as thry have a strong upright stalk. Plant in the spring; any time in Aprll will do best; I would plant in May rather than miss. Soil cannot be too ricls."

The following also appoarerl in the l'urlinglon (Iowa) Irewkeye, about the same time:

"Jast spring I plauted a double laandful of small tubers, cut still

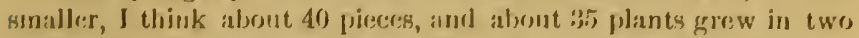
rows abrout sis feet long (1I streps). A few days agen I rlug them, and they were over seven bushels. I threw over the last dur busliel to the pirgs and they out them with avidity. I knocked the dirt off a large one, and offered it to the lorsese at the garden fence, and he eat it. Three of the best plants yiclded each one-last bushel even fult, and the majority yiclded over a peck each. They were planterl in good, moist grounil, anr hoed once. The six bushols are now in a heap In my garicen, and I intend to plant most of them. In spradiug up where my garden fence had been, I found these: tubers in the ground. They were there 18 yesess aes, when

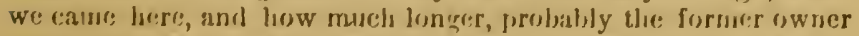
conld trill. Once of your correspesnclents is wrong about the artichoke being improsilole to erulicate. I orece planted sosme, and in the autumn turned in hogs, (without knowing anylhing about tho 
field), and the next spring inclosed it in a calf pasture, and the fol lowing spring none appcared. The yield per acre would certainly be enormous, and freezing does no injury. This saves much labor of digging before frost, or digging at all for hogs."

The common method of feeding corn, alone, twelve months in the year, is favorable to the produetion of the well-known "land pikes," so common on the farms of the West, a few years since, and tens of thousands of logs hare been lost by the so-called "hog eholera," and other diseases, wholly and directly the result of defective and unnatural feeding. We look upon more and better grass, shade, and water, with less dry corn, fed in mud, filth, and dust, as the great panaceas for the many ailments with which such enormous numbers of hogs are annually afflicted and lost. A practical and well known western writer was not far from the facts, when he said, in 1872 :

"With many of those who raise hogs in the West, but little attention is paid to their natures, habits, wants, or feed lots; the latter are allowed to become a noisome pestilence, and the only wonder is th:t t'se whole race of swine is not exterminated by cholera, blind-staggers, etc., engendered by these sink-holes of iniquity."

In a series of earefully prepared artieles written for the Prairie Farmer, by Hon. Elmer Baldwin, of Illinois, he makes the following fair statements abont the desirability of pasture and forage for swine :

"The farmer who proposes to make money by raising pork, must lave a pasture for his swine during the season of grass. Without it the balance is very apt to be on the wrong side of the le.lger after selling his crop.

"Clover is supposed to be the best, lut Timothy is doubtless equally good. Swine like it about as well, and it is more nutritious. Blue-grass does well, when better is not to be had; even a field of weeds is better than no pasture, as many varieties of weeds are excellent feed. Many a poor widlow has made a good porker almost solely on weeds from her garden.

"Where a sufficient range of pasture cannot be had, soiling does 
well. Clover or Timothy cut when green and fresh, and fed regalarly, is the next best feed to a good range of pasture.

"As soon as the grass starts in the spring, the hogs should be turned in, as they like it best when short and tender. They will subsist and grow well on grass alone, with a little salt occasionally. Some prefer to feed a little corn daily; it may or may not be good policy; they will be farther advanced for fattening, but will not fatten as well as if none is fed in summer, and with good pasture, water, and shade, they will give satisfactory results. They will not fatten on grass, but it prepares them for fattening.

"Their systems_are in a healthy state. They have no ulcerated livers and stomachs, as they will have if fed on corn through the hot weather.

"Thus kept, they are prepared by the first of September to commence the fattening process, with sound teeth, good digestion, and vigorous health. They will after that time promptly pay for all the feed judiciously given. It may be, and doubtless is, true, that a light feed of bran or light provender might be fed with profit luring the summer; but it is doubtful if corn in any quantity is oencficial.

"Feeding on corn alone, during the summer, except it to be senil thom to a summer market, is bad policy; they become unhealthy, teeth sore, appetites cloyed, and they will not feed satisfactorily in the fall, and the comparative expense of grass and corn feeding must be drawn as to which is the best policy. The cost of grass feediug, even with other light feed, is merely nominal, while a hog fed on corn, from the time it is weaned from the sow until butchered at eighteen months old, can seldom pay expenses.

"The chief end of a hog is the weight and quality of his carcass. His value depends upon his being well fattened, and the object aimed at during his whole life is to prepare him for that event. If he fails in that, his life is a failure.

"Corn is the proper food for fattening, but not for growth; and the fattening process is always, to some extent, a disease-producing process, anci if too long continued is always so.

"But when the animal commences fattening in vigorous lealth, having lived for months on green vegetable and light food, his health will remain firm tlırough any reasonable time required to beco e fat. But if fed ininterruptedly on heavy. hearty, dry food for all his life, his health, if not already destroyed, is injured, and will yiegld to such unnatural living before there is time to fatten, as will be shown by loss of appetite, restlessness, unuatural 
craving for lime, clay, bones, hen-dung, etc. A hog thus affected can inot be fattened more that season; he had better be slaughtered, (although it is (loubtful if his carcass is fit for food), or turned out for a year, to reeuperate.

"It is a common practice to endeavor to counteract this lendency to disease by feeding sulphur, coal, bones, clay, rotten wood, etc., which may be, to some extent, beneficinl; but it is like the drugs used to infuse life and health into the gouty, rheumatic, apoplectic, epicurean biped. The health thus obtained is of an inapprecitble amount compared with that of the hardy rustic who nerer had gout or apoplexy. The $h \mathrm{~g}$ is an epicurean philosopher; and as Providence deals with his biped prototype, (the votary of that philosophy), by throwing in disease at the proper time to close the scene, so the butcher's knife should do for the qualruped what Providence does for the biped, but a little in advance, just before the disease is developed. That is, the fattening process should be completed as soon as possible, (and before disease superrenes), both for economy, and to insure a good, healthful quality of meat, and when the proper amount of fat is laid on, the animal should be slaughtered at once."

It must appear to any eandid observing man that the use of grasses, peas, artichokes, ete., instead of corn, for the summer diet of hogs, must be rational and profitable, in prodneing lealthier animals, affording a fairer remuneration to the raiser, and, above all, food more neurly fit for the human stomach.

Pasture ; let this word be written in capitals, by every man who raises swine-it is the secret of success.

1

\section{II A P T E R X I V.}

\section{FATTENING.}

Healthy swine, of good breed, that hare been previously kept in such a manner, and for such a length of times (the latter depending largely on the breed) as to develop a good-sized and properly formed frame, if put upon full, but not too concentrated, feed in the early days of Sep- 
tember, are expected to, and will, lay on flesh very rapidly. The quantity will vary, with different animals, from half a pound to two and a half pounds per day, the latter quantity, however, being quite extraordinary.

Whatever the season of the year, or the number of animals to be fattened, it is important that the enclosure in which they are kept and fed, should have good surface drainage; if possible, there should be plenty of running water, that their feed-lots may not become miry, and to prevent the necessity of the animals drinking from impure sloughs, or mud-holes.

With the best management, it is not desirable that more than about forty head should be confined to less than an acre of ground; though it is frequently the practice to feed that, or a greater number, in a much smaller space, where they are compelled to eat, drink, and sleep in their own filth; after some months of this treatment, if not carried off by that ever convenient scapegoat, "cholera," they become a good and fair quality of-carrion. If any considerable number are to be fattened, and the large, medium, and small-sized hogs can be feà by themselves, in different pens or lots, it is an excellent plan to do this; and if not more than fifteen, twenty, or twenty-five are kept together, they will be more peaceable, feed better, gain faster, and be healthier, than if huddled together indiscriminately, to spend their time in continual turmoil and uproar. To be more precise about the space fattening hogs should have, we consider any space sufficient in which a reasonable number are afforded comfort, cleanliness, and a moderate degree of exercise ; while any pen is too small, that compels any number to be filthy and uncomfortable.

When taken from grass, or other bulky diet, to be fattened, the change to a more concentrated food should be gradual, as too sudden a change is sometimes attended with injurious effects, if not the loss of some animals 
outright. They should, at first, have light feed. Bran and other mill-stufi, made into slop, and given with their grain, is good, and if the refuse from the orchard and potato tield is given them, it will be benetieinl, and espeeially so, if cooked and mixed with bran, meal, ete.

Our own custom is, to plint carly in the spring a piece of good, rich ground, with some of the larger kinds of sweet corn, or an eally variety of tield com, and with it put some pumpkin seeds in every sixth or eighth hill, each way. Early in the season this corn is in "roasting-ear," when we begin feeding it to the hogs, stalk and all-as much as they will clean up. It scems exictly snited to their appetites, and starts them along in growth and fattening in a mamer that is alwalys gratifying. Cutting the early eorn from the gromed hastens the growth of the pumpkins, which then begin ripening, and are soon tit for use.

After the hogs have eaten crery monthful of the green corn that they will, we give them as many pumpkins as they want, and nsmally, eateh grown hog will eat one good-sized pumpkin, or more. Before they are given to the hogs. the pumpkins should be choppod open, and all, or most all, of the seeds removed, as in large quantities they affect the urinary organs very injuriously, and so derange an animal's system as to make him nearly worthless for any purpose.

We consider that the pork made in this way, at this time of your, yichls ns as much elear profit as any we produce. We like to cut up corn for the hogs as late in the season as they will cat a good portion of the fodder, and after this, it requires but a few weeks of feeding on clear corn to fully ripen them for slanghter. We differ from many experieneod feeders, in believing that the new curn will falten hogs fister than that a year or two old; but for finishing off a lot of porkers for marliet, we read- 
ily concede that a plenty of old sound corn is good enough for anybody.

As to continuing the use of pumpkins, we never sueceeded in raising too many, or in keeping them into the winter longer than we liked to feed them, but fattening logs should fill up with a full meal of corn before being given the pumpkins, clse they would eat too much pumpkin in proportion to the corn, and be very slow in storing up fat.- Pumpkins, like wheat bran, are useful adjuncts to the more concentrated kinds of food, but alone cannot be depended on for fattening purposes.

If there is soft, or poor corm to be fed out, it should be used first, as, after beginning to feed, a change from strong, sound feed, to that whieh is poor and chaffy, is usually for the worse. Any change during the feeding season should lo from light to heavier, and more nutritious food, and never the reverse. When, by gradually inereasing the quantity of fattening food, the hogs have beeome accustomed to it, they should be given at regular hours, early in the morning, at noon, and late in the evening, as much corn as they will eat up clean, but no more.

'This cantion is applicable to all other foods as well as corn, though we are aware that comparatively few logs are fattened in the corn-growing regions, except upon corn in the ear, and probably the time is far off when it will be otherwise.

So easily and abundantly raised, it lias become the principal food for fatting all kinds of farm stock, and being so common, is fed in many cases without a proper knowledge of iss adaptability to the animal economy, as is shown by the constant tendency to disease and degeneracy in our domestic animals. Its exelusive use is not the best eeonomy, but being so easily produced, and in sueb convenient form for feeding, especially in cold weather, it is simply courting ridicule to protest against it ; we will, 
novertholess. ronture to introduse how an itom smboly. ius the views omdorsed by mamy of the most loumed sei-

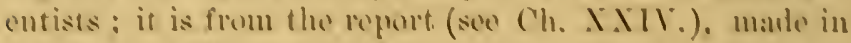

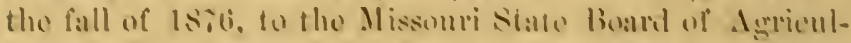

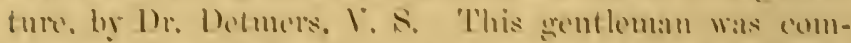

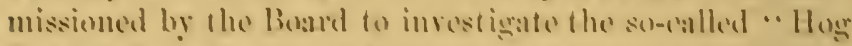

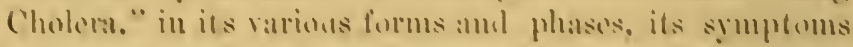

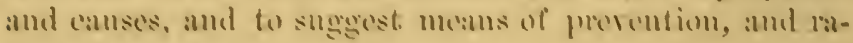
tiomal tristmont.

He writes as follows:

"Finally, I wish fo say a few words in regard to a hygignte mistake

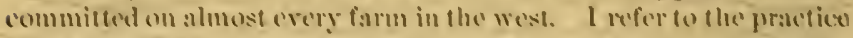
of fording the swime exchsivedy with corm, a proctioe which ere-

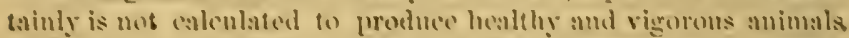

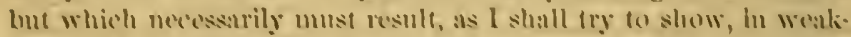
oning the organism, and in ereating a predisposition to disense, How much or how litfle this praction has contributed in produchng the now prevaling epizontic intluenza of swine 1 am not prepatred to deride. I have, however, reasons 10 stpplose that this pratetice

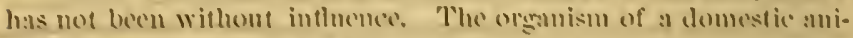
mal is eompused of about tiften fo twenty dements, or molecomposable comstituents of matfer, mited in numerous orgmic com-

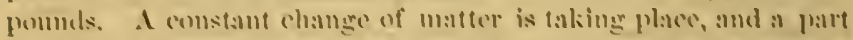
of these elcments, in form of ormanic complomels, is comstamtly wasted, and entried oft by the propesses of s:erefion and exeretion. The organism, therefore, in order to remein hesthy, and to mains:lin its normal compesition, must merive, from time fo tims, :m

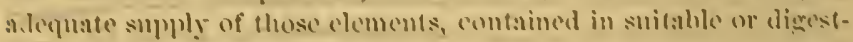

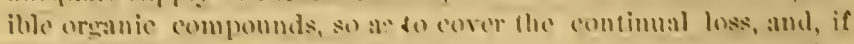

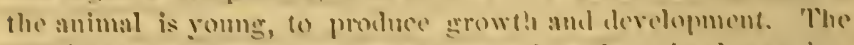

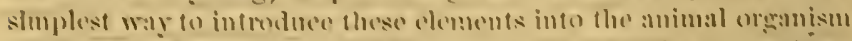

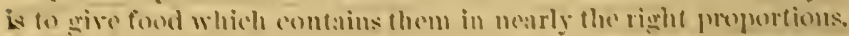

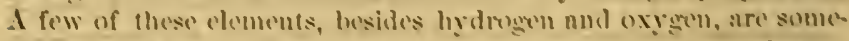

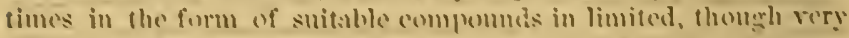
seldom suthicient, quantities in the water for drinking: for instunce, cinleimm, in the form of lime, irom, etc. One impertant

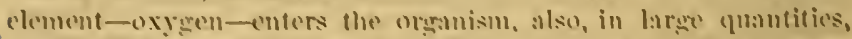

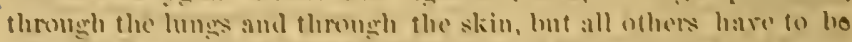
introduced wholly, or almose wholly, in the Form of foud. Almost sall kinds of food, howerer, milk frerlinps exeepted, lack some im. 
portant calcments in their conprosition, contain others in insufficient quantities, assd still oblusers in greater absudance thas required. 'Thercefore, if such a kind of fored is given exchusively-eorn, for fustance-which is destitute of some of the miseral clesnents, and contaiss only un insuflcsicnt quantity of nitrogenoses ompunds. which uro of sos grent importanes in the anienal organization, irrogularities and disonders, in the exercisc of the various functions and organs, will lw: tla: un:tvojdable desults."

P'rof. S. A. Krialy', an extensive breeder of thoroughbred swine, at Vinton, Iowa, to satisfy linsalf that tor, much corn, withont other forol, was detrincrital to the health of pigs, marle some experinucuts, one of which he srocaks of as follows :

"Two years since, I experimented in fereling dry corn and water to a thrifty, vigorous pig, abrout twelve wesks sold. In three weeks there wore indications of fever; the fourth werk be becarnes stiff in his limbs, extremely costive, with skin dry-apjutite yet gesod. The: fifth week there; was great weakness in tho lind parts-swelling of the sheath, retention of urine, costiveness, and ficklos aprestits. The: diet was then changed to dish-water and corsed bran drinks; in thres wecks thrs pig was apprarently well."

If kejet in dry lots, or ferl in perns, plenty of trough roorn shesulil toe provider, and at least twice a day thrs hesegs ehondd have as rnuch clcan water as they will rlink, and practical rnen know that this is no, incorsiderable quantity.

Whatever the feed rnay be, it should be given in such a manmer that they will be foreced to cat as little filth as [rossible, and if corn can be fed on a clean floor, or ground having a sod, it is an excellent pları. But when the arie. mals, to get their feed, must swallow as much mud and manure as grain, but joror results can be expected.

licgularity, as to times of feeding, and quality and quan. tity of feed, should be observed ; no animal should he fed so as to luceorne surfeiterl, and only so rnuch food should be given at once as will be entirely consumed, that all may come to the next meal with sharp appetites. The most perfect developricent does not depend so much upon 
the large quantity they ean be made to consume, as upon the ynantity they properly digest and assimilate. Next to gerod fook for the appertite, a grood appetite for the food is desirible, and should be earefully promoted ; the hogr that refuses to eat, eren for a single diag. is set back in his fattening for two or theo days, and sometimes for a fort night. In faet, the fitilure of a hogrs appetite denotes something radieally wrong with him, if not with the entire herd anst its management. 'The quantity of food will valy somewhat, and usually in frosty or freezing weather. more will be eaten, to matiutain the animal heat, th:m when the tempersture is higher and the atmosphere contaus considerable moistme. Ciood foeding consists in giving every particle the hogs will eat, withont learing any, or losing their appetites, and to seeomplish this, intelligent eare and elose observation are necessary. The old salying, that the lazy former, who sits on the fence watehing his hogs until they are through ating, generally markets tho heaviest pork, is in oxemplitieation of the rules of proper eare in feeding. Quiet and comfort are indispensable to thrift, so dengs and boisterons boys shonld be kept away from the feed lots and pens. Wo have always foumd it eonvenient to secustom our hogs to some particular eall, which will bring them together, and sometines they can thus be called into places where it would be about impossible to drive them.

We salt our own hogs, by putting small quantities in their swill, and sulphur is giren in the same way. Bituminous or soft coil, chincoal, wood ashes. and rotten wood, are relished by hogrs as condiments, and we think that these should be kept within their reach.

('omfortable, sheltered beds, not too deep and dnsty, are equiralent to a comsiderable amount of food, as stock sulfering from cold esmot. thrive, and to warm them with grain, applied internally, is moh more expensive tham grood nests and shelter, ipplied externally. 
One hundred prounds of jork from ten bushels of corn, is the usual estimate made by western farmers who feed whole corn, but ferd in a different form, and in conjunction with other foord, it will make much more, as has been many times fully demonstrated by careful seeders, both in America and linrope. 'l'he exanjule of the farmers in the New lingland states is valuable, as they are noted for raising the best of porth with small corn crops, and no "cholera." 'I'tie gencral methonl pursuerl

"Is to commence fatening by briling potateres, pumplekn, aproles, or other vegretaliles, and mix it little bran, shorts, or forovender, with the coroked vergetables whon loot, thus thoronghly coroking the meal. It is then placesl in tulss or vats, and alloweel to slightitly formont, when it is ready for use. The amount of meal is gralually increased until near killing tine, when meal well cooked is given alons:

"The incal is connposed of oats, buckwheat, and eorn, or any other coarse grain, or of any two of them, generally finishing with corn meal alone. Thus treated, they fatten mueli faster than on dry corn, and at inuclu less expense. It costs more lahor, but at a season wlien it e:an he well spared, and it is well recompensed,

"The Englislı system is still more dliversified. Thry use all kinds of vegetalul's-potatoes, turnips, carrots, brots, peas, beans, harley, and oats; the grain steamed or ground; the vegctables corked and mixed with slop from the homse, lairy, distillery, brewery, ctc. Even grass ancl clover is cut and mixed with the feed, and almost every substance of light crst and any nutriment, is nicely prepared and finds a ready market in the maw of the omnivorous hoge."

We do not wish to be unlerstood as arguing, in this chapter, or in this book, that corn is not a suitable forod for swine, or that it is not the best single fat-producing material for the money in the world, for general use; but would enforee the fact that a variety is esisential to perfect health and developenent in all animals, and a single article of food beeomes satisfactory to none, - not even to a long.

A very satisfactory methorl of fattening hogs, largely 
practised in the west by those who "stall feed" cattle, is to put shotes, of one liundred to one hundred and fifty pounds weight, with the cattle whenever grain feeding is begun-generally about the first of Oetober-at the rato of titteen to twenty shotes to ten steer's, the number dopending on the amount of grain used, ame the manner in which it is placed before the rattle. In the fine weather of fall and early winter, it is eommon to feed corn in the fodder, or in the shmek, by throwing it upon the grass in the pasture; the farorite way is to foed in two dilferent enclosures, and each day to turn the hogs into the one where the eattlo were fed the day previons ; this enables them to pick up the leavings of the cattle, withont trampling on and over the day's feed, until the eattle have eaten is much of it as they wish.

When full feed is given to eattle in this way, about two shotes to each steer is not too many, but when corn is fed in tight boxes and troughs, so that but a small proportion is seattered, from one shote to one and a lialf per steer will keep the feed lots well glemed.

If a greater number are kept, they will need to have extra grain giren them, in order to fatten rapidly; but if simply growth is the object, three shotes will fare pretty woll in following each steer that is on full feed.

'The grain roided whole by the eattle seems to be so softened and so digestible, that hogs thrive on it amazingly, so that the larger ones are soon in a condition for market, and others can oecupy their places in the feeding lot.s.

IIogs seldom fatten moro satisfactorily, rapidly, or with less outlay of labor, than when handled in this way, and the plan is justly held in high favor, from the fact that every pound of increase from the droppings and scattered corn is clear gain, none of which conld be ntilized without the much-abused hocr.

Ono common defect in this method of managing hogs 
is, that they are not generally provided with suitable sleeping quarters, where they can be comfortable, without crowding, and out of dinger of being trampled and horned by the cattle.

Autumn, with its mild weather, is the profitaljle seasson for making pork and liud, and hogrs not ferl with cattle, slionld be far along in their fattening before severe winter weather sets in. When loges become so fat as to gret up and abont with diflienlty, it is a loss to feed them longer, and the packer and the barel slonlel take them in.

In foeding soft or coroked food, a kerosene barrel mounted on wheels will answer, but whore something not quite so high, and less circumscribed at the top ean be construeted, it will be found more convenient.

\section{H $A$ P'I' E R X V.}

\section{COOKING FOOD FOR SWINE-FOOD COOKERS.}

The gurestion as to the economy and general desirability of eooking food for swine, has long been a subject of discussion and speculation, yet there probably is quite ats much diversity of opinion, anong farmers in general at the present day, as at any previous time.

The surrounding conditions and circumstances, have much to do in deciding the question of economy; and while one farmer, under certain circunstances, conld feed a considerable portion of cooked grain and secure satisfactory returns therefor, another, differently situated, thongh perhaps in the same neighborhood, and raising the same class of swine, might be unable to do so without actual loss.

Under favorable circumstances many laave, l,y careful experiments, thoroughly satisfied themselves that tho 
practice of cooking is largely protitable, and others, from experiments fully as eareful and thorough, havo alrived at eonclusions limectly the reverse.

There cam scarcely be a doubt that eooking hard, dry corn, renders it more casy of digestion, enabling the animal to extract the maximum of motritiro material it comtains, and that, ordiuarily, fod in this form and of tho proper comsisteney, it atterids a larger pereentage oi flesh and fat, than if fod in the raw state. A large majority, we think, of those who have given attention to the subjeet, admit this : at the same time, a respectable and intelligent minority, vote na!. That it is practically profitable, on a majority of farms, to pursuc a system of cooking the food for largo stocks of swine, is not gencrally coneriled.

Among the reasons for regarding cooking as impracticable, are, the scareity of timber for fuel, the extra labor involved, and the general lack of fixtures and facilities for cooking, and foeling the food in its cooked state.

Vast numbers of those whose farms are located in tho best corn-growing regions, would, hy the single item of fnel, he detered from mulertaking it, even if convineed that cooking would give, from the cooked food, a considerable increase of flesh and fat over that cousumed raw.

Others, with fuel comrenient and abundant, and fully satisticd of the importance and ceonomy of feeding cooked grain. are practically prevented from earying out their convietions, by the seareity and expense of reliable, intelligent help. 'There are others still, with so much wood and timber, that it is a burlen, and who have holp to spare, yet haring no very decided riews for or against cooking, suppose that some hundrods of dollars would have to bo expended in buying. fitting "1p, and learning to nse the rery simplest apparatus that would possibly answor. Wo shall fry to disabuse the minds of this last mentioned classs further on in this chingter. 
The Messrs. II. M. \& W. P. Sisson, of Galeshurg, Illinois, in a pre-cminently prairie country, are uncommonly successful breeders of swine in large numbers, and, at some seasons of $t .1$ : yeur, use a consirlcrable quantity of cooked food. Knowing them to be practical men, pursuing their business for profit, rather than for the purpose of demonstrating any preconceived theories, we solicited of them a statement of their conchusions, from experience, as to the profit and desirability of cooking food for swine, on a small, medium, and large seale. In their reply, they express views so nearly identical with those entertained by us, that we checrfully present their conclusions in lieu of our own. 'They write :

"We have bren corsking food for hogs, inore or less, for the last six or eight years, and we state as the result of our. experience and olservation, that in the great hog and corn prodncing States, cooking ford for hogrs, generally, will not pay; still, there are times and circumstances which will make cooking, to a limiterl extent, profitable.

"We do not think it profitable to cook corn, or meal, for hogs, whenever they can have aceess to good, tender grass, and the temperature is such that corn can be soaked in water. Soaking will then answer every purpose, but in winter, when there is no grass, and dry errn is the principal food, is the time that cooking will pay, if ever.

"Hogrs need somcthing besides dry corn, (it is ton concentrated), something with more bulk; and to meet this requirement, we do some cooking. If a slop is made of corn and oat meal, midllings and bran, ancl finished up with potatoes, pumpkins, or squashes, all well cooked, and fed in connection with dry corn, we think the advantage will be very apparent.

"It is not absolutely necessary that this should be fed more than once a day, but pigs, especially, should havo enough, once a day, to fill up and properly distend the 
stomach. In speaking of pigs, we mean those six months old, or more.

"It is our opinion, that the disease known as hog cholera, is rery largely occasioned by the almost exclusive use of corn. Hogs should have a rariety of food; they need something besides corn; oats, bran, potatoes, etc., fed for a change, and for variety, are rery beneficial.

"We use a simple pim, or boiler, that has an iron bottom and ends, with plank sides, so that the contents can be drawn off into a vat. The boiler has a light cover, and is about eight feet long, three feet wide, and fiftcen inches deep. Such an arrangement is chcap, and can be made profitable, principally in winter.

"We will say, in conclusion, that we do not beliere that it will pay, either on a small, medium, or large scale, to generally substitute cooked for uncooked food, for hogs in the great hog and corn-prodncing regions of the West."

Mr. Thomas Wood, the snecessful breeder of Chester Whites, mentioned in another chapter, writes us :

"For the last eight or ten years, I have cooked feed for my hogs, and with the steamer that I have fixed up I can make one or two hogsheads of mush at a time. I cook food as a matter of economy, believing that about one-fourth the grain is saved thereby. I generally feed of corn two parts, and oats one part, ground together, and with this I feed considerable whole corn, particularly in the fall before it gets hard and dry. Feed, when cooked, should be allowed to get nearly cold before it is given to the hogs.

"A few days ago, I weighed and put in separate pens, two sows, in every way the same, and of the same litter. No. 1 weighed 292 lbs., and No. 2 weighed $280 \mathrm{lbs}$. I fed No. 1 for 17 days on unground corn, cooked; she consumed 2 busliels and 21 quarts, and gained $36 \mathrm{lbs}$. No. 2 I fea the same length of time, on whole corn, raw, of 
which she consumed 3 bushels and 13 quarts, and gained 30 lbs.

"The summer before the above experiment was made, I fed eight shotes with corn and oats, (one part oats, and two parts corn), ground, and made it into well-cooked mush, and frequently weighed them, in order to see if it would pay to make pork at the then ruling prices of corn (55c.), oats (40c.), and pork (7c.). The result was that the pork paid nearly two prices, for the corn and oats, while the manure paid for the labor."

U. H. Stowe, of Indiana, had four pigs of a litter, which weighed $245 \mathrm{lbs}$. each, and four of another litter that weighed $170 \mathrm{lbs}$. each. He took one of each litter, and put in a pen by itself, and the other six in another pen, and gave both an equal chance, allowing both as much good, sound corn as they could eat, for six weeks. Tho corn fed to the six was thoroughly eooked whole, and that fed to the two was raw, and ferl in the usual way.

The hogs on the raw corn gained ten pounds to the bushel, and those fed on the cooked corn gained just fifteen pounds to the bushel consumed.

Prof. Wilkinson, of Baltimore, says: "I conducted an agricultural school and experimental farm for eight years, and experimented with feeding cooked food of every description used for cows, horses, swine, working and fattening cattle, and poultry, and carefully noted the results. These were in all cases very remunerative; so much so, that even with the defective, inconvenient, and expensive apparatus nsed-for want of better-in steaming, manipulating, and feeding, I found there was an average profit of fully 25 per cent."

\section{THE EXPERIMENTS OF S. H. CLAY.}

Readers of agrienltural papers have, no doubt, frequently seen allusions to experiments made by Mr. S. H Clay, of Paris, Ky., in cooking food for swine. 
Mr. Clay was an exteusivo hreedor of Berkshires, being the gentleman to whom was awarted the grand prizo of \$1,00(), for tho timest, display of swimo at tho Nutional

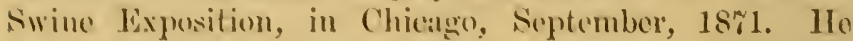
mate these exproments to sottle, in his own mind, tho question as to what citent, and moler what cireum-

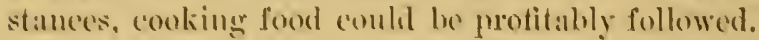

'Tho experiments were begun, July l(ith, with six barrows, cach about twolvo months old, at which timo they weighed ats folluws:

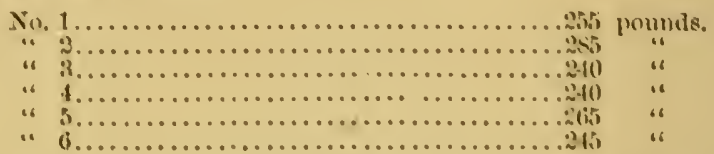

They were fed together for twolve diss on cooked eom meal, redued to such a comsistency that the animals comld reatily drink it. At the cmit of twelle days, they were separated. When each pigr weighed as follows:

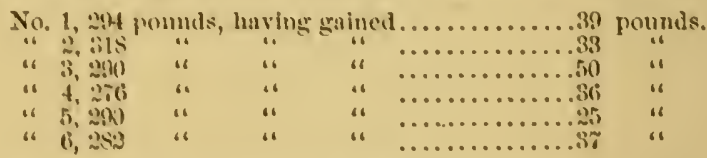

Nos. 1 and : were put in a pen together, and for 30 days fod on boilod corn, consmming 390 pounds, or six bushcls amd 5.4 poumds, "pon which No. 1 gamed 50 pounds, and No. : ganined i: poumts, or together, 10: pounds.

For the same period, Nos. 3 and twere fod togedher, in a pen, on moal, hoiled and redneed to a thin slop, comsmming :Sit pommis, or font hnshels and 4 (i pounds, mpon Which No. 3 gaincd 30 pounds, and No. 4 ganed 50 poumds, or torgether, so pumds.

Nos. 5 and 6 were for the same period fed on dry corn, cousuming 405 poumds, or serom lushols and 13 pounds. Upon this, No. 5 gained 10 pomnds, and No. if gained 32 pounds, or together, 4: pounds. 
'The following will illustrate the foregoing in tabular form :

\begin{tabular}{|c|c|c|c|}
\hline & $\begin{array}{l}\text { Noss. } 1 \text { aruel:. } \\
\text { Perileal Cisrn. }\end{array}$ & $\begin{array}{l}\text { Nos, } 3 \text { ared } 4 . \\
\text { Shrilerl Alerel. }\end{array}$ & $\begin{array}{l}\text { Non. S) and } 6 . \\
\text { Itry lorn. }\end{array}$ \\
\hline 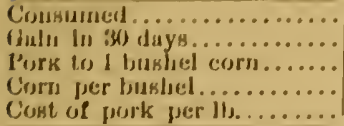 & 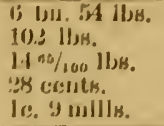 & 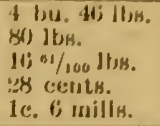 & 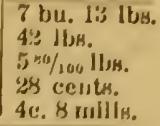 \\
\hline
\end{tabular}

At the end of the :3) dicys, a change was made, and the hougs fed as follows: Noss. 5and 6, that had been feed on dry corm, were for the next 20 days given eooked meal; they eonsmmed 234 pounds of meal, equal to 4 bushels and 10 lbs. of shelled corn, upon which No. 5 gained 40 Ils.s., and No. 6 gained :34 lbs., or toggether 74 lbs.

Nus. :3 and 4, that hai been fed on corokerl meal, were forl for the sanne period of "2f days, on dry corn ; they com-

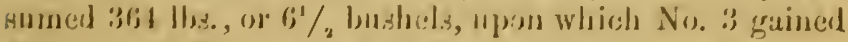
31 lhs., and No. 4 gained 10 lbs., or together 44 lbs.

Nos. 1 and 2 were still kept on the dict of boiled corn, with alest the sane results as in the former trial. The following table shows the ressults of the $2 f$ day's' trial :

Ciлsum:1......................

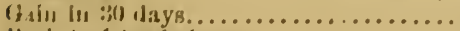

P'srk to 1 hisshis corn...............

Corn per bushsel.....................

Coskt if postk par lis.....................

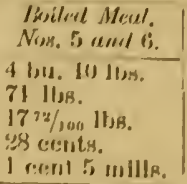

Ilry (iswite. Nor.:" ared 4. 6) 1,u. $28 \mathrm{ll}$ ก.s. 41 1), (i; $27 /$ uis It)s. $2 y$ cerista. 4 rents 1 mill.

It alpears that, during the twelve days, when the hogs were first jut up together and fed cooked meal, No. 5 gained 25 prounds, but when they were separaterl, and ferd thirty days on dry com, the same hog gained but 10 Jhs., while it consumed $20 \% \% \%, 11 \%$ of of corn. With corn at 28 cents per bushol, euch pound of jork produced would cost in this case 10 cents and 1 mill; but when in the secend trial the hog is again fed on boiled meal, it consumes but $117 \mathrm{lbs}$. in 26 days, and gains forty pounds, and gives the pork gained at a cost of one cent and four mills per pound. 
In the first period of twelve dilys, No. 4 made a gain of thirly-six pounds, or three poumels per diyy, on the. cooked meal, and being eontinued on the sime food for the thirty days following, eonsumed but $135 \mathrm{hl}$ s. of meal, and gained thereon fifty pounds, at a cost of one cent and three mills for each pound of gain. lint the same hog, when fed on dry rorn in the second trial, consumed 15: lbs. in twenty-six dilys, and male a gain of only ten pounds, at a cust per poumd of nine cents und one mill.

In his experiment, Mr. Clay obtainel from one bushel of corn, fed in the form of cooked meal, about the same quantity of pork that he did from three bushels, ford withont enoking or grinding. In other words, he foum one hundred bushels of dry eorn made him less pork than did forty bushels of com, when grouml and cooked. isy cooking the feed, he wats also enabled to make one hogr gain filty pounds, while another hog, (equal in all respeets), gained on dry eom but ten pounds in the same length of time.

That those gentlemen who believe whole or raw corn will make as much or more pork than when eoolict, or gromul, are not, without reasons for the fath that is in them, we are eertain, and the following experimentswhich we must assume wore made as anchully as the others-will not lesen it. The first experiment was made on the farm of the Iowa Agrienltural College. hy Mr. M. Stalker, the Supreinlendent, and as some, to whom the results wore displeasing. have ridienled it, and sneered at its author, as a "book farmer," "theorist," and "coll. ge professor," it is fair to remark that those who know him, say he is a gentleman pre-eminently distinguished for his strong common sense, with a thorough practical knowledge of the erery-day business of farm life.

He reports:

"On the first day of July, (18\%5), an experiment was com. 
menced, for testing the comparative value of different kinds of food for pigs. The food used wiss dry corn, souked corn, cooked corn, dry meal, and cooked meal. Five lots of pigs were sclected, as nearly uniform as conld be taken from a lot of fifty. Three pigs were put in each pen.

"The pigs were all of Berkshire blood. They were placed in floored pens, and given nothing but their regular allowance of food, with all the water they would drink.

"The corn was all shelled .nd weighed. During the months of July und August, each lot consumed fifteen bushels of eorn, or the same amount ground into meal. The pigs were carefully weighed each week, and a complete record of the results taken.

"During the last week in August, when the weather was extremely warm, pens No. 4 and 5 sustained a small loss, while Nos. 2 and 3 made a slight gain.

"Below are given the results.

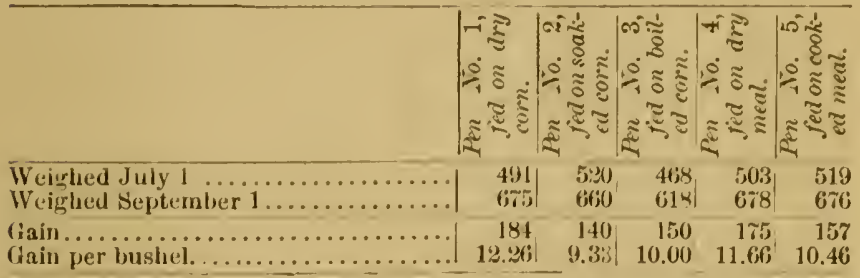

"On the 1st day of Septembrr the pigs were all put upon full feed, each pen receiving the same kind of focd as during the first two months.

"The experiment was concluded for each pen when fifteen bushels had been consumed, except No. 2, which had consumed but 13 g bushels up to October 25 th." $^{2}$

Welghed September $1 \ldots \ldots \ldots \ldots \ldots$.

Weighed Oetuber $23 . . . \ldots \ldots \ldots \ldots . . . .$.

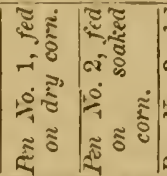

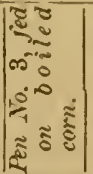

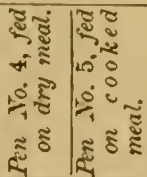

Weighed Oetober $25 . . . \ldots \ldots \ldots \ldots . . . .$. 675

\begin{tabular}{rr|r|r|r|r|}
870 & 618 & 678 & 676
\end{tabular}

Weighed October $28 \ldots \ldots \ldots \ldots \ldots \ldots \ldots \ldots \ldots \ldots$

Gain ...........................

Gain per bushel.................

195

$13.00 \quad 10.24$

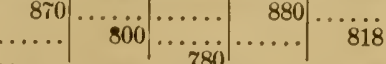

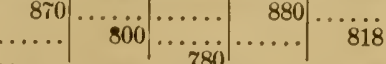


"Mr. R. L. Bingham, of Bloomington, Grant county, Wisconsin, states that, after purehising an Anderson steamer, he commenced, February 15th, an experiment in feeding nineteen pigs, about nineteen weeks old, a cross of Berkshire with common stock. Prior to the experiment, the pigs had the run of the farm, and had been fed as much raw com as they would eat. Then for a period of twentyeight days, they were fed as before, with corn in the ear and ali the water they conld drink. At the close of this period, the totas gain in weight was 667 !bs., made trom feeding 55 busiels of corn -a gain of $12 \mathrm{lbs}$. for eaclı bushe! of coril. Thy were then fed with thick mush, made by bringing the water to a boiling heat, and then stirring in the meal ground fine, with the steam still on, allow. ing the meal to cook tive to ten minutes, anct adding salt; this was fed to them warm, three times a day, as much as they would eat clean. At the end of twenty-eight days they were again weighed, showing a gain of 676 lbs., made on 75 bushels of corn, less tolla gain of $9 \mathrm{lbs}$. lor each bushel of corn consumed. He then put 11 of the pigs on raw corn again, continuing to reed the others with cooked meal. May 25, after a trial or six weeks, those on raw corn averaged a gain of 44 bus, each, and the othere an average gain of 37 lbs."

Prof. Menry, of the Wisconsin Experiment Station, has summarized all the most carefully made experiments at edueational institutions in America, including those by himself, on a variety of foods, and as a whole they afforl a wonderfully strong showing against the practice and protit of cooling for swine. The showing is this:

\section{Agricultural Frperiment Stution, Wisconsin.}

Cooked barley meal ( + trials) was to uncooked as.......... 93.7 to 100 Cooked com meal (3 tiluls) was to uncooked as.............. 81.0 to 100 Cooked corn metl and sh uts (2 trials) was to nucooked as .. 86.1 to 100 Cooked whole corn an! shorts. (2 trials) was to micuolied as.. 85.8 to 100 Ontavio Agricultural Colleye.

Cooked peas (2 trials) were to uncoolied as 84.9 to 100 Michigan Agriculhural College.

Scalded corn and oatmeal was to wet menl as ............. 101.7 to 100 Tansas Agrientural College.

Cooked shelled coru was to uncooked coru as ............... 84.0 to 100 Iowa Agricultural College.

Cooked shelled eorn ( 2 trials) was to uncooked as ........... 82.3 to $0 \mathrm{C}$ Cooked corn meal (2 trials) was to uneooked as ............... 79.3 to $10 \mathrm{C}$ Iraine Agrieullural College.

Cooked corn meal (9 trials) was to uneooked as............. 82.9 to 100

"It will be noted." observes Prof. Henry, "that in every instance but one, that at the Michigan Agricultural College, there 
is a loss resulting from cooking; in the exception the gain is very slight, being less than two per cent. Even in this case tho meal was not really cooked, but scalded by boiling water being poured on to the meal in a pail and covered up, while the other meal was fed wet with water."

Many other cxperiments and a vast fund of valuable information have been collated and very lucidly presented in the elaborate article (Chap. XVIII.) prepared by Mr. Joseph Sullivant, of the Ohio State Board of Agrieulture. High authority in such matters has said: "No man engaged in prork-raising ean afford to pursue his business, without giving Mr. Sullivant's paper careful investigaltion. He will find there embodied, in a reasonable space, a earcfully prepareil and full statement of the experiences of ulany, that it would require him days and perhaps weeks of study and rescarch to obtain."

\section{A FOOD COOKER.}

Much money has been wasted in the purchase of various steamers, boilers, cookers, and similar apparatus, patented, high-priced, and highly extolled, at least by patentees, makers, and venders. Not a few credulons persons have been almost persuaded that, if possessed of one of these wonderful inventions, they could raise hogs on so near no grain at all, that a fortune was inevitable, if the business was well followed.

While the apparatus of each different make has some point to recommend it, no great number of meritorious features are combined in any one that is simple and cheap, and we have observed that those who invest in this class of merchandise, sooner or later permit it to get out of repair, fall into disuse, and if not left out in the weather, it is stored in some out-building, or corner of the barn, while, in time, the room it occupies is looked upon as being worth more than the old "contraption" itself.

The royalty to the inventor, the manufacturer's profits, the margins to retailers, together with the considerable 
freights on such heary wares, make them high in price to the farmers, and the results obtained from them are, in many eases, and from various canses, so musatisfuctory, that the entire experiment is regarded as an expensire failure.

For sucessful operation, and simplicity and economy in construction, we regard an apparatus made and used

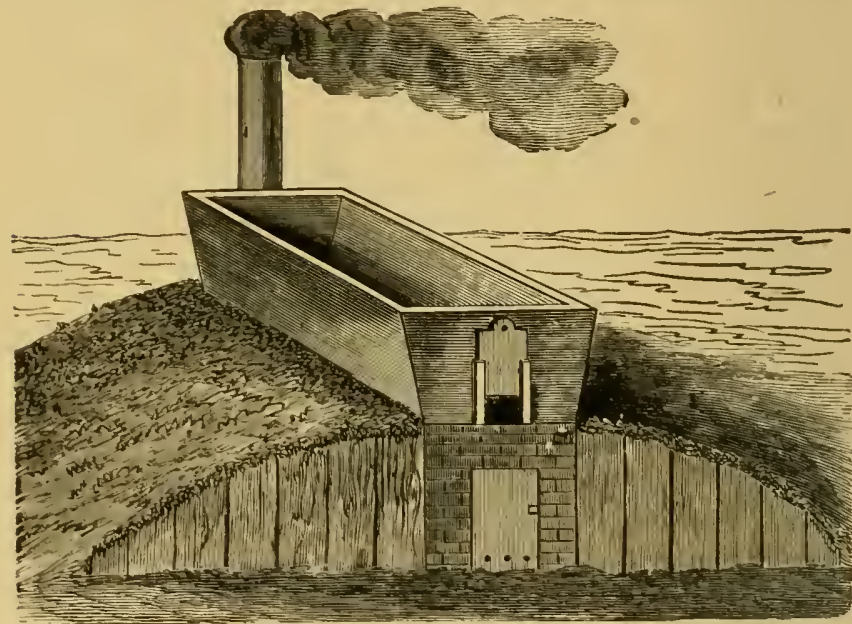

Fig. 7. MrR. CLAT'S FUOD COOKER.

by the lite S. H. Clay, of Paris, Ky. as about as good, if not superior to, any patented cooker that could be bought for two or three times the cost of this. It consists of a box two feet wide, and six or eight feet long, and 18 to 24 inches deep, made of two-inch hard-wood plank, and is somewhat wider at the top than at the bot. tom. The bottum is of heary sheet iron, nailed firmly to the sides and ends. The box rests on brick or stone walls, high enough to give a plenty of fire-room underneath. A trench in the ground might do in lieu of walls. The front of the fire-place has a door of sheet or cast iron, with a damper, by which to regulate the fire. The 
door is of sufficient size to jermit the use of refuse knots, and the chunks found about the farm or wood-pile.

At the rear end, a chimney, or suitable eseape for smoke, is constructed; for this purpose large sized stovepipe answers well. In making the box, thick white lead should be earefully spread on the bottom edges, before nailing on the iron bottom; this will make it less likely to leak.

After setting the box on the walls, earth is banked up against them; the earth should extend up against the sides of the box somewhat, to prerent the escape of smoke and sparks through the walls.

For drawing off the contents of the box, a sliding gate, with a tin spout under it, is arranged in the front end. A cover, made of inch pine, or other boards, cut on a bevel with the flaring sides of the box, should fit inside of it, instead of on the top, and have some sort of handles at each end for convenience in lifting it.

A few strips of wood, at intervals, on the bottom, and upon them a false bottom, with numerous small perfor:tions, is desirable, as it will prevent meal, or other fine fool, from burning at the bottom.

Whenever the box is emptied, it should be eleaned out ander the false bottom, and if emptied of food when there is a fire below, some water should be poured in at once, to prevent injury to the pan.

With such an arrangement as this for boiling corn, shelled or in the ear, potatoes, turnips, pumpkins, beets, ete., with cheap fuel, and feeding the mass when cold, or but moderately warm, we believe that almost any farmer can secure a fair compensation for the time and labor expended in cooking a goodly portion of the food for his hogs, and if he cannot do this, surely cooking must be unprofitable.

When it is more suitable to soak the corn than to cook it, the box will be useful for this purpose, and for heat 
ing water and sealding hogs, at butchering time, it will indeed be found "a good thing to have in the family."

\section{H A P T R X VI.}

\section{HOG HOUSES AND PENS.}

We have seen but few expensive buildings, erected for the use of swine, that were in any great degree satisfactory; the more elaborate and expensire these were, the less desirable and practically valuable they seemed to be.

Large hog houses, usually bring too many animals together, where lack of room, ventilation, and exercise, faror disease and vermin; besides, they increase the difficulty of making suitable arrangements for prsturing, and fail to afford sufficient sunlight, and general comfort.

On most farms, a small or large number of swine can be provided with comfortable housing from such material, and of such construction, as will readily suggest themselves to almost any man fit to be entrusted with the care of stock.

Sleeping apartments should be enelosed on the northeast, and on the west, with a tight wall of stone, boards, logs, or even hay or straw, covered well ; in lien of something better, hay or straw makes a very good roof. The apartments should be open, and front the south, to admit light and warmth from the sun, and should be provided with fresh bedding. Such house will, perhaps, answer as well as one constrncted after the elaborate plans of an architect. Reasonable protection from cold and storm, dry, clean bedding, and fresh air are requisite in sleeping 
apartments for swinc, and the farms are few where these cannot be secured at a merely nominal cost.

A well-known westeru breeder says:

"The common plan of erecting large buildings for the rearing and keeping of swine, is objectionable, upon the ground that, during the season of the year when a pen is particularly required, such buildings are usually cold, dull, and dark, receiving the rays of the sun only a few hours each day.

"Light, air, and sunshine appear to be especially agreeable to the animals, particularly during the fall, winter, and spring months, and are unquestionably conducive to health and growth. IIence, in erecting buildings, or pens, for hogs, these things should be especially looked after, as a cheerful pen will be likely to give you a ehecrful pig."

For those desiring a breeding house that is somewhat elaborate, we present the one shown on pages 142 and 143 , it having probably had as much careful thought given it, by a practical breeder and farmer, as any similar establishment in the country, and it is not without many useful features to recommend it.

It was planned and erected by a gentleman of practical experience for his farm in Wyandotte County, Kiansa:

The building (fig. 8 ) is 100 feet long by 30 feet wide, built of first quality of pine, upon stone foundations, and arranged with a view to the utmost economy of time and labor in feerling and care of the stock.

By reference to the ground plan (fig. 9), it will be seen that there are fourteen pens on each side. These are divided by movable partitions, so that one or more pens can at any time be thrown together as one. Each pen is furnished with a fender, to prevent the young pigz from being overlaid and smothered by the sow.

Through the centre of the building is a drive-way, 12 fect wide, through which runs a wooden track and truckear, for carrying barrels of feed from the steamer and feed rooms. Each of the troughs extends through tho 


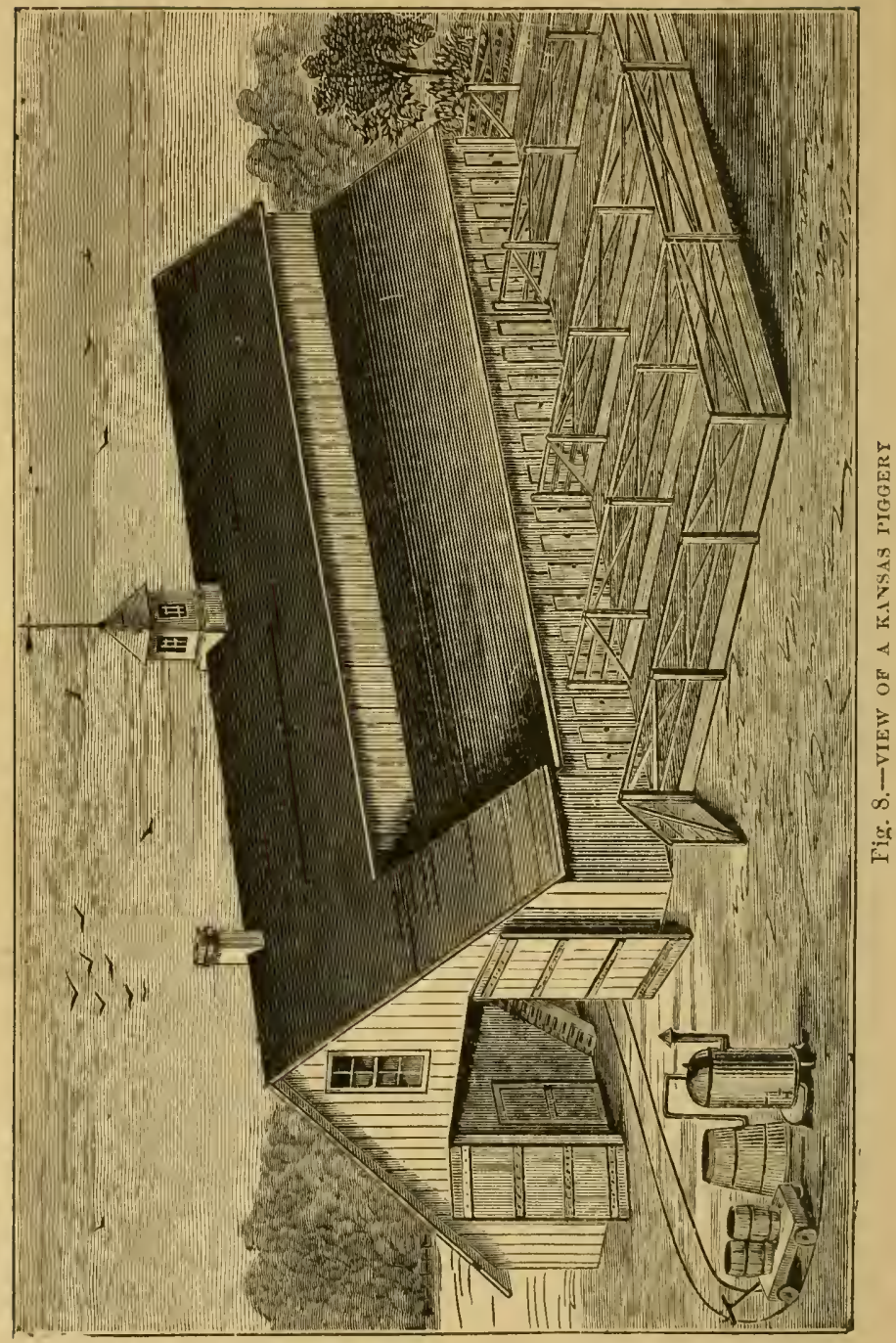


partition between the pens and the drive-way, so that feed can be poured into them from the outside, without interference from the animals within.

All of the peus open into outside lots, (it was found impracticable to show them all in the view), the gates between them forming, when open, an alley, through which animals can be readily mored from one portion to another, and manure wheeled out to the compost heap.

Fresh spring watcr rous through all the out-lots on cither side of the building, and extensive clover pastures are accessible from the north, cast, and south.

Its owner raised logs by the hundred, and claims for this establishment that it economizes labor, and affords excellent care and protection to a large number of animals, giving warmth in winter, and shelter and rentilation in summer.

By opening the large doors at exch end of the building, and the fourteen small doors on each side, the freest rentilation is secured in both directions; the interior walls of the pens are, of course, but a few feet high, and the space abore them open.

In its owner's opimion, the abundant clover pastures adjacent, and the strong, nerer-failing springs, constantly supplying an abundance of the purest water, are among the chief recommendations of this structure, and they are prime necessities to the success of any other swincbreeding establishment.

Mr. Charles Snvad, Secretary of the National Association of Swine Breecers, contributes to the Prairie Farmer Annual the plar of an inexpensive house for swine, a riew of which is given in figure 10, and a plan in firgure 11. Of this cuilding Mr. Snoad says :

"The plau submitted is one I have just adopted, and, as will be observed. It is so simply constructed, that it can be built by almost any farmer.

"The importance of a southern exposure, for the continued good 
health and comfort of all animals during the fall, winter, and spring montbs, will hardly be questioned. In erecting large buildings on the usual plan, these advantages are almost wholly lost sight of. This building is 70 feet in length, and 16 feet in width,

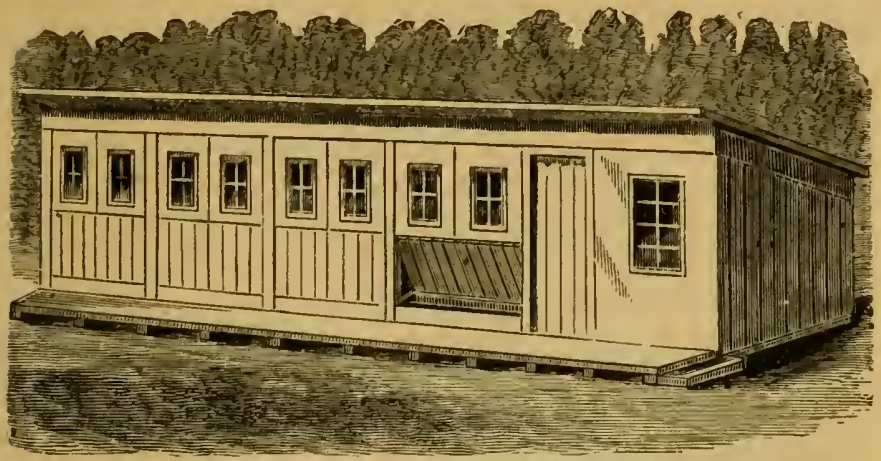

Fig. 10.-VIEW OF MR. SNOAD'S PIGGERY.

including front plstforma. The cost of it will not exceed $\$ 100$, with lumber from $\$ 17$ to $\$ 21$ per thousand.

"The roof is of stock boards, with a groove cut in each edge, and battened. For cooking or preparing food for the stock, or for the storage of grain, a portion of the building may be appro-

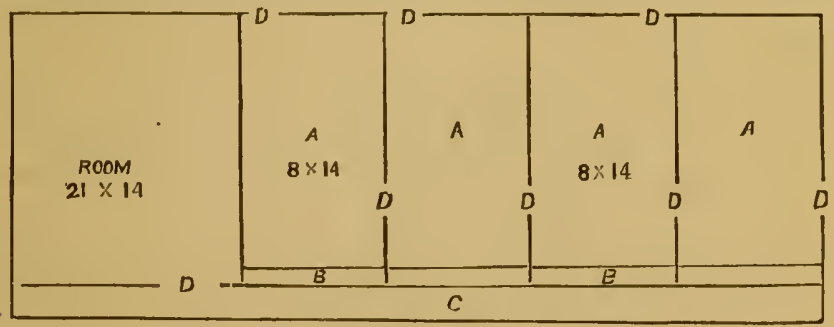

Fig. 11. - PLAN OF MR. SNOAD'S PIGGERT.

(The sash doors are designed to swing in, and the gates to suing back over the troughs, while putting in food.) $A, A$, Pens, $8 \times 14$ feet; $B, B$, Feed Troughs; $C$, Platform in front, two feet wide; $D, D, D$, Doors.

priatek, adding to the hight, length, or width, to suit the convenience of the proprietor. Such cinanges in the division of pens may also be made as mily be deemed best.

"The most important features claimed are: warmth, light, air, 
and sunshine. It may be considered an objection, to be obliged to feed from the outside of the building, but it is believed that the comfort and thrift of the animals, will more than compensate for this apparent additional trouble. Nany a cold, cutting day, maz be made one of comfort and warmth, by taking advantage of the sunshine.

"In locating the storage and cooking room, the point best adapted to the demands of the case, should be selected. If it is more convenient to do the cooking near the residence, I should have it done there, in preference to using a part of the piggery.

"Many of the steamers or boilers now in use, ean be placed in a very small room, and frequently in the dwelling house, condueting the steam to the point desired for cooking the food, through iron gas pipe.

"Moclifications ancl changes are necessary in almost all plans, to adapt them to the wants of different individuals and locations."

An Illinois feeder gires in the Stock Journal, Feb., $18 \%$, the plan of a good feeding floor and pen, as follows:

" $\mathrm{A}$ floor $30 \times 30$ feet will gire room enough to feed 100 to 120 hogs, and may be made to do twice that service, by feeding a second lot after the first have had time to eat, as I have frequently done for months at a time, and with good satisfaction. The floor should be divided, leaving each part $30 \times 15$ feet, and each accommodating from 50 to 60 hogs at once, which, I think, is as many as ought to be fed together. The lumber necessary for such floor is about as follows:

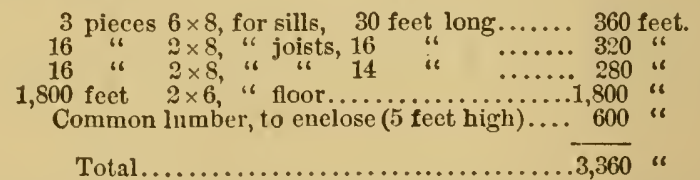

except posts, which may be set upon the sill or into the ground, and will not add materially to the expense-if on the sill, then 28 pieces $4 \times 4,5$ feet long, 175 feet, and lumber for division, 100 feet ; lumber, all told, 3,635 feet, costing here $\$ 13$ per thousand, or $\$ 47.25$ for the whole. The floor might be made of inch lumber, instead of two-inch, as in the bill, hut is not so good, nor is it cheaper in the eut.

"The sleeping place I prefer, should not he less than 30 or 40 feet from the feed floor, as less manure will be taken there, and it will 
scldom be wet, as is sure to be the case if aljoining. The sleeping house site, as well as the intervening space, should be raised or filled up several inches higher than the surrounding ground, to prevent surf ice water from rumning in, and also to afford drainage. Set the house on this : $14 \times 32$ feet, [mine is], high side 9 feet, low side $6 \mathrm{fcet}$, shed roof, of common boards; requiring in all-for siding, roofs, and division-about 1,400 feet of common lumber, and a few picees of scantling or straight hard wood poles to nail to and support the roof; then add six or eight inches of sand or sawdust to the floor and the intervening space, and you will have no mud."

When but few pigs are kept, or it is desired to keep up a small number for some particular purpose, they can in spring, summer, and early fall in many cases, be kept adrantageously in small portable pens, which can be moved a few feet every day or two ; by doing this the pigs can have the benefit of fresh clean earth and grass continually.

For easy handling, such pens should be light, and are best made of pine lumber, the size of the pens varying according to the length of the boards used, from 10 to 16 feet, and these may be 4,5 or 6 inches wide-the latter being much the best for strengt?.

Insteal of nailing the lumber to small corner posts, we find it better to make four separate panels, nailing the lumber firmly with wrought nails, to cross-pieces or cleats, of good 6-inch boards, as long as the pen is to be high, three to each panel, and when set up, keeping secured by some sort of flexible fastening.

When nailed together at the corners, the frequent moving of the pen wrenches and breaks the nailed corners loose, and the pen becomes a wreck, a result which cannot oceur when the parts are jointed.

If a pen 14 or 16 feet square is built, it is sometimes convenient to have an extra panel, which will fit down in the midalle of it, hetween cleats, which will at once conrert the one pen into two of hall its size.

These pens should be provided with a convenient 
trongh, and some sort of temporary roof, over one end or corner, at least suflicient to afford a good shade at all times of the day, which, with plenty of water, is indis. pensuble.

We have fonnd a movable pen or two, quite a necessity in the summer season, but eamnot recommend any pen, that is so light and airy as this, for cold weather.

It frequently hippens, on a farm where machinery is used, that four wheels may be found, from 6 to 24 inches in diameter, that may be filstened to the cormers of the movable pen, on which it may be moved with facility from place to place, without much effort, or, snitable wooden wheels, of any size or number, can be made of the transverse sections of a solid hard-wood log, and attached to the pen, to enable it to be moved with ease.

On nearly every farm, one or more well constructed morable pens, will be found a good inrestment, as a few pigs can be kept clean and lealthy in these, if moved often on solid ground, with less tronble than in any other way; the farmer who tries them will not readily re-adopt the old-time four-rail-square pen, that stood in the same place for a dozen or more years.

In whatever style the pen may be built, we would impress on the builder the convenience and importance of having the troughs level, with eross-slats on top, six or eight inches apart, and arranged so that feed can be posired in to their entire length from the outside of the pen. These assist in the more equal distribution of the feed, enable each animal to secure its share, prevent the stronger from monopolizing and fouling the trough, by standing length wise in it, and also enable the attendant to feed withont being jostled, or charged npon, by tho always importunate swine.

Feeding a dozen or more hogs, by pouring slops into one end of a long open trongh, is excellent for two or three of the strongest animals, but the others usually havo 
to stand back, and be content with so much, or so little, of the feed as their more powerful companions reluctantly leave, for want of more capacions stomachs.

'Troughs are much more durable if made of good sound oak, or other hard wood, than of pine, as hogs sometimes get into a habit of gnawing them for the taste of something that has soaked into the wood, and a pino irough is, in this way, soon destroyed.

\section{H A P T E X VII.}

\section{SLAUGHTERING, CURING, AND PRESERVING.}

Every experiment we know of, that has been made to ascertain whether it was more profitable to the producer to sell his hogs alive, or kill, and cure the pork on the farm, and then market it, indicates that, in most years, the farmer may realize more profitable returns by marketing the cured product. In fact, we have seen but few intelligent farmers who did not andmit this, but as they generally need the money represented in the year's hog crop, by the time the hogs are ready for market, they prefer to realize on them at once, rather than assume the risk and wait the longer time necessary to suecessful curing, especially with the poor facilities many of them possess for this branch of the business.

A lot of uniform, well fattened houss represent cash, any day in the year, at any point in the comntry; hence the temptation to dispose of them as soon as the proper condition is reached, is excerdingly strong. This, no doubt, accounts in a large degree for the fact, that the bulk of the hog erop raised, is sold on foot to drovers and shippers, to be slaughtered at the immense packing estaib- 
lishments near large cities, and only so many are killed on the farm as are neded fur home consumption.

In this, we timel the frobable reason, why no more attention has been prid to finding ont and practising methods in killing and euring of pork, somewhat improved orer those of former generations.

Wo are not aware of anything lating leen written, nor have we seen practised anything, from which we conlal infer that the farmers of the present time slanghter and dress their swine in a better way tham did their forefathers. The old method of knocking down, eutting into the neck to serer the jugnlar rein, and pieree the heart, scalding in water not ynite boiling, into which a quart of ashes has been thrown " to make the hair slip," scraping with knives, hoes, and iron eandlesticks, and then litting by main strength, the naked, slippery hog to the pole or fixture, from which he is to hang for gntting and cooling, is yet in rogue on nearly erery firm.

Those who raise the best of hoges, too often have few conveniences for lontehering, and those hurriedly ame awkwarly made, generally by the hired man, while the water is heating in the morning. A small expenditure of labor and money would secure such ficilities ats would render butchering-day much less disagreeable.

After the hog is secured for sticking. cither ly being caught, knocked or shot down. it shonld be turned square ori its back, and no twist allowed in its neck, so that the sticker will be sure to serer its main arteries, without allowing the knite to penetrate, or injure, either shonlicer. We do not deem it best. or even desirible, to pierce the hart, but prefer to let the animal lie from loss of bloorl, which it should do in the space of fire minntes, or eren l.ss, if the knife lias been properiy used. When properly stl.ck, the blood should leap from the gash, in a stream as large as the gass itself, while, or before, the sticker remores the knife. 
A barrel or cask is, for many reasons, a poor vessel in which to scald a hog, and any farmer who ammally butchers a half dozen good-sized porkers, should provido himself with something less circumseribed and inconvenient, to say nothing of the difficulty of keeping a sufficiency of water at anything like the proper temperature in it.

For farm use, the best scalding vessel we have seen, is a heary box, 6 or 7 feet long, 30 inches wide at the bottom, and $20 \mathrm{or} 24$ inches deep, with sides somewhat flaring.

This should have a sheet-iron bottom, well supported on the under side, and be set over a stone or brick foundation, in which there is a convenient chamber for making sufficient fire to readily heat the water in the vessel above, and by which it can be kept thoroughly heated for the length of time required by any number of hogs. At its rear end should be a pipe, or chimney, for smoke, and the sides may be banked up with earth. 'The description and engraving of the food cooker in Chit]p. XV. will afford some useful suggestions for the construction of a vat for scalding. The top of the vat should be about $21 / 2$ feet above the level of the ground. On a level with the top, on one side, there should be built a strong platform, about 6 feet wide, and 8 feet long, from which to scald the logs, and upon which they are to be cleaned, after scalding. At the rear end of this, the ground should be grarled up even with the platform, or a sloping platform built, to facilitate getting the hogs on to the main platform, after they have been killed. For convenience in lowering the hogs into, and lifting out of the scalding water, two or more ropes, 8 or 10 feet long, should be secured to the side of the platform next the water, and resting on these, the carcass can be lowered or raiced with companative ease, by two or three men. On the botton of the vat, there should be some wooden strips or a slatted frame, to prevent the hog from lying directly 
on the iron bottom, as with much fire in the furnace, the skin would soon cook or buru.

'The animal is immersed for a few seconds, and then, by me:ns of the rope, riaised out of the water, to allow the air to strike it thoroughly, and then immersed again.

When the hair readily leaves the skin, especially on the head, legs and feet, the logg should be removed from the water as soon ats possible, and speedily stripped of every hair. When this is done, the hind legs should be freely ent into, below the gambrel joint, to reach both main cords, under which the gambrel should be entered. The gambrel should be of strong wood-hickory or oak is best -and from 24 to 30 inches in length, according to the size of the hogs, and should be slightly notehed on the up. per side of each end, to prevent the legs from slipping off.

Posts or forks should be so set, that a strong pole resting on them, will be in p:rrt over the platform, about six feet from the gromnd, and on this the hogs ean be humg, and slipped along towarl either end, ont of the way, after they have been thorougly scruped and rinsed down.

Opening the hogs should be done by some one familiar with such work, and no directions here would be of practical value.

After remoring the intestines, the month should be propped open with something, and all blood carefully rinsed out of the lower part of the body and neek. The next point, and a most important one, is, to let the careass, well spread on the gambrel, hang until thoroughly cooleci in all its pirts; muless this is observed, the pork cannot be eured or preserved in good condition, however mueh palns may bo taken with it.

CURING AND PRESERYINC.

To cure meat of any kind, it is desirable to have it from animals that, before slaughter, were in a considerable degree matured, or lasd attained their natural growth. After dressing, as before intimated, the first reguisite is 
to thoroughly cool the eareass, and for this it should bang in a low temperature, for thirty-six or more hours, but on no account should it freeze, especially not after being dressed; freezing its outer surface, surrounds the interior of the flesh with a wall, through which the animal heat, still remaining in and around the bones, cannot escape, and the result will be souring and speedy decay at the centre of hams, shoulders, ete., that outwardly appear in good eondition.

Having so large a per cent of fat, side-pork does not readily become over salt, and there is really no danger of injury to any but the leaner portions of the careass by too much salt; yet where salt is dear, economy would dictate that only so much be used as is actually necessary as a preservative.

Salting with and without brine, are both popular methods, and both are so satisfactory, that we deem one as good as the other.

If brine or "pickle" is used, no danger is apprehended from insects during the piekling process; the brine extructs the blood and other juices from the meat, which rise to the surface, (more rapidly in warm weather), and there decomposing, are likely to contaminate the entire contents of the cask, unless given occasional attention.

The preventive of trouble in this direction is, to occasionally subject the brine to boiling; the impurities will rise to the top, and are to be skimmed off ; in this way, the brine may be kept jure, and its strength undiminished, for any desired length of time.

In "dry salting," or salting in barrels, boxes, or piles, withont the addition of water to form a brine, it is of the utmost importance that no cliance be afforded for flies to deposit eggs, or maggots, or to even come in contact with the meat. If flies liave had access to the pork, it cannot then be saved, unless at once put into brine, or kept in a 
temperature so low the eggs eamnot hateh, the latter heing not often praticable.

'T'he se:ason of the year, in which meats may be eured on the farm with the best snceess, is from Deeember 15th to Fibriary 15th, the interval between these dates atfording two indispensable conditions, viz.: cool weather and immmnity from insects and pests.

Pork is eut to snit the demands of the different markets in which it is sold, and tie various uses for which it is intended, but the aim shonl., in all eases, be to lave it in such form as to pack sungly, and we repeat, never pack dewn until thoroughly cooled throughout.

Where it is intended to nse brine, the meat may bo packed in layers; salt, at the rate of eight pounds to each lunudred pounds of pork, is to be sprinkled crenly over and aromid each layer, until the eask is full; then clean rain or other pare water, is poured in, until all the interstices are filled and the meat thoroughly covered. None of the meat should, at any time, be allowed to remain above the brine, and in open easks, or tubs, some attention will be necessary to keep weights so arranged as to hold it under.

Many persoms prefer to prepare the brine by adding to the salt some sugar, or molasses, and saltpetre, dissolving these in the water, and pouring the piekle over the paeked meat. A very good recipe is as follows: For 100 pounds of ports take $t$ ounees saltpetre, 3 pints eommon molisses, or P pounds brown sugar, and y pounds cleam silt; when thor onghly dissolved, pour orer the meat, which it will cover, if properly packed. Many lowil the pickle before nsing it, as the impurities from the salt, sugar, etc., will rise, anu ean be skimmed otil ; when this is clone, the brine shonld be thoroughly cool, before alding it to the meat.

Hams and shoulders, to keep well afterwards, shonld he in pickle from one to two months; the length of time depending on their thickness. For euring them witl. 
out brine, a favorite recipe is: 12 jomms fine salt, 2 quarts molasses, $1 / 2$ pund powlered saltpetre; when these are well mixed, they will lave abont the consistency and "lpueatrance of damp) brown sugar, and will be sufheient for 150 prounds of meat. Rub hams and shoulders thoronglyly with the mixture, and lay singly on a platform in a cool, dry plice. At the end of the lirst, and of the seeond week, mb them again as at first, and then expose to continums smoke for ten days.

$\Lambda$ simpler way, in which any portion, or all, of the hog's careass can loc corer, is to put a layerof, say, half an inch of salt on a platiorm, floor, or the bottom of a large box, or eask, then a layer of meat, on this a liberal sprinkling of salt, ancl so on, until all is packed and the top well covered with salt.

Sucl portions as are not to be smoked, shonld be stored in brine before insects appear, and the smoked meat may, like. the hams of commerce, be covered securely with canvas, and whitewashed, or packed well in bran, lry ashes, oats, or shelled corn. For consideruble rpuntities, pucking in tight barrels is a goor plan, and for family use, a swinging shelf, with sides and ends covered with wire cloth, inside of which the picees are hung, is convenient, and is also secure against rats and mice, as well as insects.

The room where any kiud of enred meat is to be kejt, should he dry and cool, and the darker the better.

The preservative principle ol smoke is known as creosote. Simolie male by luming corn-colss is highly estemed, but those engagerl in curing meats on a large scale, consider that the purest, sweelest smoke is obtained from dry hickory salp-wool, stripper of its bark. If the smoking process is tor much hurried, the ereosote will not have time to penetrate the entire substance of the meat, hnt ten days steady smoking is, in all eases, sufficient, unless the pieces are unusually large and very thick. 


\section{L.AliD.}

Lari is almost a pure oil, of quite a permament eomposition, for which water has no allinity, and moisturo and air have but little etloet on it. In the rendering of land from the tissus in which it is contained, lrangunts of membrame and particles of animal fibre are intermixed, which would, it exposed to the aic, yiold to decay ; lout being surrommled hy oil amel wholly enclosed, they are kept inactire. Iet, after some lime, if abmudant, they may become ehamged and give an odor and taste of decay.

Care should be exereised as to the purity of larel that is designed to be kept, as well as to the exclusion of the air from the ressel. Stone-ware jars (not eartheu) are the most desirable ressels for storing lard, which should always be kept in a cool, dry atmosphere.

\section{CHAP'FR XVIIT.}

\section{HOG-FEEDING AND PORK-MAKING.}

A grreat deal of theoretical malter has been published on the subject of feeding animals. Chemical analyses of rarious ferding stuths, valuable as they are in showing their mntritire eonstituents, are not always eonelusive evidence of their practical value. l'here are? facts commected with digestion and assimilation which ean not be arrived at by chemical analysis. ITe therefore give a chapter which embolies practical experienee based щpen seicutitie knowledge. So one familiar with the angiculture of Ohio need be told of the high position which is oceupied by the Sullivants: whether als men of seience or als practical agriculturists, 
whowe farning operations lave been condueted on a soale unequalled, at least on this side of the continent.

The essaly which forms this chapter, is by Joseph Sullivant, Esis., whose ville experience and thoroughness as an investigator, joined to his high scholarly attainments, are well known to the people of Ohio, where he has long been prominent as an oflicer of the State Board of $\Lambda$ grieulture.

'The cssily appented in the "Ohio Agreultural Report" for 1869 . Its value as a contribution to argrienltural literature, and the desire to make it more widely known, are sufficient reasons for giving it a place in the present work.

llaving had nceasion to inquire concerning the conditions necessary to make houg-feeding protitable, I was somewhat suryrised and puzzled at all the discordant answers, and therefore undertook to investigatic this sulyject for myself, and propose here to give the resultiz arrived at, and the basis of my conclusions. In this way my labor may at least become valuable by eliciting the truth from others, who may he indueed to enlarge, confirn, or disprove my work.

As to my sourees of information, suffice it to say, my materiats have been colleeted and claborated from various eliemical works, agricultural books, reports and transactions of societies, newspapers and periodicals devoted to rural affairs, and eonversations with intelligent and practical farmers, and from my own experi enee.

When we come to know the diverse and varying circumstances under which pork has loen matle, we no longer wonder at the discrepant opinions and results, and clearly perceive they are owing to the different methorls pursurd, in which, oftentimes, tradition and caprice have governed raller than an intelligent understanding of the ent in view, and the best and most economical means of olthaining it.

The farmer who pens his hogs without shelter from the weather and without bedding, or a dry lecding place, and leaves them to wallow and waddle belly deep in the mire, where the ears of corn sink out of sight, and where the hog has literally to root for his living, eannot expect him to fatten quickly and economirally.

Nor can the results be fairly compared to those obtainet where attention las becn paicl to warmtl and protection from the weather, 
a dry feeding place and clean food. And these differing circum. stances probably make all the difference of a fair remuneration for food and labor in the one case, or little or no profit in the other.

If we could always command circumstances, we might then reasonably hope for a greater uniformity and reliability of results.

The diseoveries in animal physiology, as well as in agricultural chemistry, throw much light on our subject, and point us to the proper path to be pursued, and the direction in which we must look for a rational explanation of the most successful practices already pursued by intelligent breeders and feeders

The thorough understanding of the data and principles so acquired, and the proper appication of them, will eventually lead us to valuable results.

We may undoubtedly anticipate much benefit from a more thorough diffusion and understanding of the important principles involved in animal physiology and agricultural chemistry, hearing as they do durectly on some of the most vital questions in agriculture. There is yet, however, a wide gulf separating theory from practice, although all successful practice is but the right application of scientıfic principles, whether we recognize and apply them, or ractice in ignorance of them.

There is one subject or paramount importance so intimately connected with the question of the best and most economical methods of rearing and fattening animals on the farm, as to demand the most serious consideration; I allude to the manure produced and its value in arresting the decreasing fertility of our soils, which is made evident by the gradual, but certain, diminution of the product of onr crops, and of which the lessened yield of wheat, in regions formerly productire, is a striking eximple.

The detcrioration of our cultivated lands may be easily account. ed for in the fact that for sixty years we have constantly taken from the ground, and, during this long peried, returned little or nothing to it. If this condition of things is to be clanged, we nust alter our methods of farming, and by systematic rotation of crops and by manuring, or by both, endeavor to restore, or, at least, keep in present condition our severely cropped lands, for only by returning some portions of the organic and inorganic matter removed ly the crops, can we keep our soil in a fertile state, for, no matter how rich orivinally or at present, it will, sooner or later, become exhanste l unless fed in proportion to the yield required from it. Owing, however, to the great original fertility of our soil, it still yields a fair remuneration for the lahor bestowed upon it, and we have not yet reached the point where 
manure becomes indispensable to the growing crop, as in many places in Europe, where the question is, not how much meat, but how much manure is produced on the firm? And where the profit of feeding cunsists simply in the value of the manure produced by the animal.

Manure is most valuable in proportion to the nitrogen it contains; and as we propose to feed our hogs on a grain containing twelve (12) per cent of nitrogenized nuterial, the manure should be valuable to us when preserved and applied to our lands. Still, fortunately for us, owing to the cheap production of Indian corn, so far as the profits of feeding are concerned, we may leave the manure so produced entirely out of consideration, and I proceed to the main object of the investigation.

\section{WILI IT PAY TO FATTEN HOGS ON CORN ?}

In answering this question, the first and most important consideration is that of food; and the value of equal veights of the different kin ls used for fattening purposes will depend upon the proportion of nutritive material in each, and the cost of production.

Without goiag into detail as to the ultimate clements, we shall content ourselves with adopting the classification of the proximate principles of food into

\section{NITROGENOUS AND NON-NITROGENOUS.}

The first representing the plastic material or flesh formers, and the last the heat and fat givers; classing these last together because the surplus carbon not required for maintaining animal heat an: 1 respiratio: is stored $u p$ in the tissues in the form of fat.

It his been proven by direct experiment, that both the nitrogenized and non-jitrogenized elements must exist in due proportion in the food t's maintain any animal in a healthy and growing condition, and if it were fed exclusively on one or the other it would pine and die.

However, it is highly probable that if the nitrogenous clements risted in many articles of food in less quantities than is aetually found to be the case, they would still be sufficient for the wants of the animal organism; for a very considerable portion of the vilrogen ingested in the food passes away in the excreta without assimilation, but at the same time adds additional value to the manure.

Th": following table gives the proportion of this necessary cle. ment in one hundred (100) pounds of the different substances thit: 
are or may be used in the fattening process, and also the non-nitrogenized or fat giving principles, and the total amount of carbon:

TABLE No. 1.

Table of the Chemical Composition of some Principal Articles of Food.

Explanation. -The column of "Ileat and Fat Girers" signities-I. Starch; II. Sugar ; 11I. Fut or Oil.

\begin{tabular}{|c|c|c|c|c|c|c|}
\hline Nome. & inter & $\begin{array}{l}\text { Flesh } \\
\text { jorme- } \\
\text { ers. }\end{array}$ & $\begin{array}{c}\text { Heat and jot } \\
\text { givers. }\end{array}$ & $\begin{array}{l}\text { binuir- } \\
\text { utentof } \\
\text { starch. }\end{array}$ & $\begin{array}{l}\text { Stiures- } \\
\text { al mat. } \\
\text { lers: }\end{array}$ & $\begin{array}{l}\text { I Total } \\
\text { carturn. }\end{array}$ \\
\hline & & 8.0 & II. & 8.8 & 0.9 & 38.6 \\
\hline auss. & 12.0 & 36.0 & I. 57.0 & 1.8 & 3.0 & $40.8 t$ \\
\hline uekwheat See & & 10.7 & $\begin{array}{r}\text { I. } \\
\text { II. } \\
\text { II. }\end{array}$ & 58.45 & 1.4 & 31.74 \\
\hline abbag & 89.4? & $1.4 i$ & $\left.\begin{array}{cc}\text { III. } & 0.4 \\
\text { I. } & 7.01 \\
\text { III. } & 0.0 々\end{array}\right\}$ & 7.2 & 0.12 & 3.89 \\
\hline arrot & 86.5 & 1.3 & $\left\{\begin{aligned} \text { I. } & 6.3 \\
\text { II. } & 5.0 \\
\text { III. } & 0.15\end{aligned}\right\}$ & 11.3 & 0.80 & 6.11 \\
\hline Clover (Fed) & 81.01 & $4.2 \pi$ & II. 8. & 10.1 & 1.32 & 6.785 \\
\hline ors & 79.71 & 3.8 & $\begin{array}{rr}\text { I. } & 8.14 \\
\text { III. } & 0.69\end{array}$ & 10.27 & 2.08 & 6.607 \\
\hline ottou. & 9.28 & 41.25 & $\begin{array}{l}\text { I. } 16.45 \\
\text { III. } 16.05\end{array}$ & 54.4 & 8.05 & 46.0 \\
\hline di & 12.0 & 12.0 & $\begin{array}{c}\text { I. } 68.5 \\
\text { III. }\end{array}$ & 5.3 & 1.5 & 41.73 \\
\hline & .07 & $22.1 t$ & $\begin{array}{l}\text { I. } 39.1 \\
\text { II. } 11.98\end{array}$ & 7.1 & 7.25 & 1.7 \\
\hline & $\begin{array}{l}\text { Dry. } \\
87.3\end{array}$ & $\begin{array}{l}3.0 \\
4.0\end{array}$ & II. 73 & $\begin{array}{l}69.0 \\
12.5\end{array}$ & $\begin{array}{l}6.3 \\
0.7\end{array}$ & $\begin{array}{l}32.2 \\
6.637\end{array}$ \\
\hline Milk . & 88.6 & 4.0 & $\begin{array}{rr}\text { III. } & 3.5 \\
\text { II. } & 4.6 \\
\text { III. } & 2.0\end{array}$ & 8.8 & $0 . \pi$ & 5.533 \\
\hline Oats........ & 13.2 & 18.0 & III. 5 & 8.6 & 2.54 & 46.8 \\
\hline (1)m & 15.0 & 29.6 & I. $\begin{array}{r}58.5 \\
\text { III. }\end{array}$ & 63.3 & 2.5 & 39.35 \\
\hline arsi & 85.1 & 1.4 & I. 10.0 & 12.4 & 1.0 & 6.245 \\
\hline Pon 1 & $6 \pi .14$ & 3.41 & $\begin{array}{l}\text { I. } 14.15 \\
\text { III. } 0.86\end{array}$ & 16.21 & 1.95 & 8.98 \\
\hline & 75.0 & 1.4 & I. 23.5 & 22.7 & 1.0 & 11.468 \\
\hline & 15.0 & 8.8 & $\begin{array}{r}\text { II. } 62.7 \\
\text { II. } 2.5\end{array}$ & $\pi 1.2$ & 1.36 & 9.9 \\
\hline & 01.1 & 1.2 & $\begin{array}{rr}\text { liI. } & 2.9 \\
\text { J. } & 3.3 \\
\text { II. } & 3.0\end{array}$ & 6.2 & 1.5 & 3.39 \\
\hline I3 & 8.1 & 4.0 & II. 4.6 & 7.6 & $0 . \tau$ & 5.147 \\
\hline & (0) & $: .83$ & $\begin{array}{ll}1 & 13.69\end{array}$ & 15.58 & $3.6:$ & 8.98 \\
\hline & 4 & 8.21 & $\left.\mid \begin{array}{rr}\text { II. } & 4.5 \\
\text { III. } & 1.0\end{array}\right\}$ & 46.9 & 1.5 & $\approx 6.93$ \\
\hline
\end{tabular}


The farmer has lere a wide range from which to choose, and, knowing the cost of production or market price per one hundred (100) pounds of each, can determine which to select as the most advantageous for his purpose.

If the plastic material, or flesh-formers, be assumed as the basis of value, then equal weights of the grain and seed foods will stand in the following orler: Cotton-seed cake (decorticited,) heans, linseed cake, neas, oats, Indian corn, rye, hurkwheat, barley; lut on the hasis of fat and heat givers, they stand, first : Barley, Indian corn, rye, peas, o:ts, beans, buckwheat, linseed cake, cotton-seed cake. Taking the whole of nutritive matter, they range in the following order: Indian corn, barley, beans, peas, rye, oats, buckwheat, linseed cake, cotton-seed cake, potatocs. Estimated according to the total amount of nutritive inatrial, there is not much difference in the theoretical value of several of these substances, but Indian corn liearls the list, and, containing in itself all essenti:1 clements for thr: growtlo and fattening of aniulals, we shall adopt it as our standard of value and eomparison.

Measured, then, by the theoretic value, one hundred (100) pounds of corn are equal to the weights, as exhibited in the following table:

TABIE NO. 2 .

In fecding value 100 pounds of corn cqualsBarley...........10? | Peas...........106 |Red Clover.......665 Beans..............10:; Potaloes ..........360 White Clover...... 665 Ryc...............117 Mangold-wurzei....665 Timothy grass.... 2:18 Oits ...............113 l'arsnips .........618 Lucern........... 598 Buckwheat ........1 $3:$, Carrots...........721 Cabbage..........1018

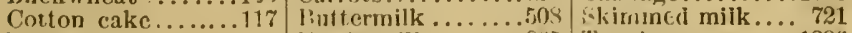

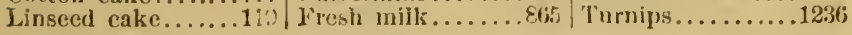

Although it appears from the first talile that cotton cake, heans, peas, and linseed cake, contain more of flesh givers tlaan corn, and might very advantageously be fed to young and growing animals, yet, upon the whole, Indian corn stands pre-eninent as the rheapest material accessible to our farmers, and the question now arises-

\section{HOW MUCH PORK IN A BUSHEL OF CORN?}

In determining this we sluall first consider the composition of corn from a theoretic and cherical view, and then, taking results olstained from the vital processes occurring in the lumman sulject, apply thrm hy analogy to the hog, which, of all our domestic animals, most nearly resembles man in his digestive apparatus.

Looling only at the chemical composition of corn, and separat- 
ing it into flesh formers and heat and fat givers, at twelve (12) per cent of the first and furty-one $(41)$ per cent of the latter, there would appear to be neurly tuirty $(30)$ in the bushel of corn, to bs transformed into an equal quantity of pork, througl the organism of the log. But I shall presently show that, whatever the value of corn by the chemical stundard, it is not all transformed into pork, and therefore there is not thirty (30) pounds to be obtained from a bushel of corn.

It has been determined by competent observers and experimenters who have carefully investigated the subject, that a certain amount of nitrogenized and non-nitrogenized matter, or flesh formers and heat and fat givers, representing the carbonaceous materill, is required to keep an adult man of one hundred and fifty (150) pounds weiglut in good condition; that is, neither increasing nor diminis'tin physical, or mental. As the hog performs no brain work, and is supposed to be almost i a state of rest while fattening, he will certainly require no more of the above elements than does the mau, and most probably less. But assuming for him the same amount, it will be amply sufficient to keep a hog of the weight of 150 pounds in as gool conlition as the man. But if the log is to fitten likewise, he unust have an additional amount of food, over asd above that which is merely sufficient to furnish the material consumed in respiration, animal heat, and the restoration of all Waste producel by the rital processes.

Before demonstrating what this amount of extra food must be, I premise that the $\log$ is to be sent to market at $300 \mathrm{lbs}$. weight.

As ha increases from 0 to 300 , it is evident his mean weight is $150 \mathrm{lbs}$; and if we can determine how much eorn is required at tilis weight, not only to restore the daily waste, but to fatten him one pound per diem in addition, we will have solved the problem of the number of pounds of pork in a bushel of corn.

Dr. Edward Smith, an eminent writer and experimenter, is a high authority on vital statisties, and was employed by the Engiish Government to examine and report upon the foods of the laboring classes.

He states that the actual quantity of carbon contained in the food of English work-people, accerding to the sererity of the exertion, is from 30 to 38 grains per pound of body weight. He also says that 28 grains of carbon to each pound of holy weight gives the measure which, when united with the proper amount of flesh formers, is sufficient to keep a man of 150 lbs. in good con aition under moderate exertion. 
Now, as has already been said, the hog, increasing from 0 to 300 lbs., his mean weight is 150 , and the amount of carbon necessary at this weight will give the mean or average amount required daily for his whole life of $: 300$ days.

Then 150 , the mean weight of the hog, multiplied by 28 , the number of grains of carbon daily required, gives 4,200 grains, or 9 ounces of carbon, to supply the waste, and keep him in condition; and 22 ounces, or a little less than one and one-half pounds of corn, will furuish the necessary elements.

But to fatten the hog a pound a day, he will require, in addition, 16 ounces flesh and fat material, which will be furnished by two pounds of corn. Thus, 2 lbs. or 32 ounces, contain 12 per cent of flesh formers, and gives $3^{84} / 100$ ounces of this material, and the same 2 lbs. containing 41 per cent of carbon, furnish $13^{12} / 100$ ounces, and $3.84 \times 13.12=16.96$ ounces, or material for a little more than one pound of pork; and therefore 54 ounces, or 3 lbs. and 6 ounces of corn, is the average daily ration while making three hundred pounds of pork in three hundred days.

$\Lambda \mathrm{s} 3 \mathrm{lbs}$. and 6 ounces are contained in $56 \mathrm{lbs}$, or one bushel, 16 $50 / 100$ times, there are consequently $16.59 \mathrm{lbs}$. of pork in one bushel of corn, according to the clata here given.

And if the amount assumed to restore the waste in the hog and keep him in condition be csrrect, then there cannot be madc more than the $16.59 \mathrm{lbs}$, bccause the elements would be wanting. The amount assigned for waste is certainly ligh enough, most probably too high; aud if we take the amount of carbon and flesh formers simply to kecp a man of $150 \mathrm{lbs}$. in condition when in a stats of rest, and modify our statement, the result would be $2 \frac{1}{2}$ ounces of flcsh formers and 7 ounces of carbon derived from 14 ounces of corn; but two pounds, or 32 ounces, being still required for tho fattening process, we have, altogrt'ier. 43 ounces contained in 896 ounees, the weight of a bus'iel of corn $19 \frac{1}{2}$ times; equal to $19 \frac{1}{2}$ 1bs. of pork.

I have found from a careful examination of experiments in feeding, but not herein set forth, that usually not more than onethird of the food is returned in the form of flesh, even in well conducted experiments; and 3 into 56 lbs., or one hushel, gives $18^{2} / 3$, and the mean of $16.59,19.50$, and 18.63 gives such a close agreement of theory with the best proctice, that $I$ conclude it is very nearly correct, and that chemistrv and physiology have answered our question satisfactorily, or at least fixed a limit beyond which it is not likely we will be ahle to pass, unless under excep. tional circumstances, and the pork from a bushel of corn will not 
exceed twenty pounds, and will approach or recede from this according to circumstances.

Shelling, grinding, and cooking, the corn cannot increase the existing amount of elements, and has for effect only to render the matter more soluble and digestible, and make the approach to the figures given more probable, than if the corn was fed in the whole and raw state.

But it has been well observed, "in every case in which life is concerned, it is not at once to be concluded that, so much material being consumed, there will be uniformly and nceessarily so much product." There are so many modifying circumstances to vary our results, that it is not probable our practice will ever give constant uniformity or perfect coinciclence with theory, or the chemical constituents of the food we employ in stock feeding. And, although we may to a great extent master the circumstances under our ow control, there still remain mexplained difticulties, arising from the inherent differences belonging to special breels and constitutions of the animals we have to deal witl, as well as the anom:lies we have to encounter whenever we attempt to apply theory and chemical principles to living organisms and vital functions, which perhaps, for a long time to come, will continue to baflle our best endearors and prevent uniform and constant results.

Howerer this may be, the conclusions drawn from the scientific principles I belicre to be entirely trustworthy, and are satisfactory, to mrsclf at least, as determining, not only the possibilities, but the high probabilities, and it now only remains to see how far our chemical view is confirmed or sulstantiated by the average results in actual practice, obtained from a great number of experiments and records; for it would not be safe to draw general conclusions from one experiment alone, howerer successful.

Te proceed to deternine, as well as we can, what answer practice and experiment retures to our question:

HOW MUCH PORK CAN BE OBTAINED FROM A BUSHEL OF CORN?

This is so important a question, bearing so immediately and directly upon the ralue of corn, that we might suppose it had been settled long ago, heyond all controversy. If such be the fact we find no recort of it, and it is here our real difficulty commences ; for, as we said in the lieginning of this paper, the answers are discordant and apparently contradictory.

I find plenty of opinions and guesses, with loose assertions, but 
comparatively a very few results based upon actual, reliable, and recorded experiments; and, after a somewhat minute research, I propose now to give the condensed results of my examinations, without going into much detail, remarking, however, that, although finding many records of experiments, I bave been obliged to reject most of them, on account of irregularity and want of preeision. In most of them the corn has been fed in a mixcd state with roots, milk, potatoes, and other substances, as well as, sometimes, whole and raw for part of the time, and then in the form of meal, cooked, and raw; and I retain those only which give precise results on the heads we have selected for examination.

\section{RAW COIN FEI) IN THE EAR.}

Taking the experiment of Clay, of Kentucky, for what it is worth, I remark that I am certain there must have been some error or local circumstance vitiating the result ; for 5 lys. of pork from a bushel of corn is much the least I lave found recorded in any experiment, and much less than was obtained by Renick and Buckingham, whose hogs roamed at will through a cornlield, wasting corn, and from the very fact of exercise and labor in getting their own food, making far less return than if the sane corp hat l been fed them in a pen.

Buckingham also tried the experiment of feeding corn in the ear to hogs in a pen, and got a return of 81 lbs. of pork from a bushel of corn.

Thom:s I. Edge, of Chester county, Pa., fed 5 pigs: of the same litter, five bushels of shelled com, and received $47 \frac{3}{4}$ hs. of pork, or $9^{3} ;$ s lls. from the bushel.

B. P. Kirk fed $49^{2} / 1$ o bushels, and had a return of over 12 lbs. of pork per bushel.

An experiment at North Chatham, Columbia county. N. Y., gave a fraction less than 12 lbs of pork from a bushel of corn.

Mr. Ellsworth, of Indiana, had 12 lis. of pork per bushel from corn fed in the ear.

Marcus E. Merwin, of Litchfield, Conn., fed 95 days, and made 9 lus. of pork from a bushel of corn.

A. S. Proctor, of Illinois, fed 61 days, and gained 10 lbs. of pork per bushel.

Wiseman E. Nichols, Morrow county, Ohio, fel 100 bushels of corn in 63 days, and made from it $1,130 \mathrm{lbs}$. of pork, or $11^{\circ \%} / 100$ lbs. per bushel. This corn, however, was simply soaked two days in water. 
Mr. Van Loon, of Ill., fed 20 days, and made a fraction over $9 \mathrm{lbs}$. of pork from a bushel of col'tl.

Mr. Behmer, of Columbus, Ohio, mate 10! lbs. from one bushel of corn.

Even including Clay's experiment, which, I think, ought to be excluded from any comparison of results, the eleven records here presented give an average of over ten pounds of pork from one bushel of corn, fed in the ear and upon the ground.

An experiment, partly of coru in the ear, which was male at Duncan's Falls, Ohio, in 1859, and communicated to the Ohio Farmer, is so instructive in several particulars, that I insert it here in a condensed form.

"Last fall, (1859), I turned my hogs into the cornfield on the 10 th of September, after having weighed them all; they were taken out Oetober $2 u d$, weighed and placed in a small lot. During this time, from September 10 th to October $23 \mathrm{~d}$, they ate down 40 acres of corn, and, estimating it at 40 hushels per acre, the increased weight of the hogs, at 4 cents per pound, just paid 40 cents per bushel for the corn they had eaten. Two diys after, or 25th of Oetober, I selected of the lot one hundred hogs, averaging 200 lbs. each; they were placed in large covered pens, with plank floors and troughs, and fed as follows: The com was ground up, cob and all, in one of the 'Little Giant' mills, stermed and fed five times a day all they could eat, and in exactly one week they were weighed again, the corn they hat eaten being weighed also, and calling $\gamma_{0}$ lbs. a bushel of corn, and pork as before 4 cents gross, it was equal to 80 cents a bushel for corn. The weather was quite warm for the season of the year. The first week in November I tried the same experiment on the same lot of logs, and the corn only brought 62 cents per busliel, the weather being coller." "Thirl week, same month, same lot of hogss, and corn fed in the same way, brought 40 eents per bushel, the weather getting still colder." "Fourth weck in November, weather still colder, fed as above, and the corn bronght 25 eents a bushel. This lot of hogs was now sold and another lot put up, which had heen fed in the lot on corn on the cob. This lot was weighed and fed as the last for five weeks in December, and the corn averaged 25 cents; the weather being about the same as in Norember." "This lot was weighed again in the middle of January, and the corn fed during that week averaged 5 cents per bushel, the thermometrr being down to zero. Agrain the lot was weighed, and they just h.ld their oron; the temperature being below zero from one to ten 
degrees." And from the above the writer concludes it will not, as a general thing, pay to feed after November.

An analysis of this experiment shows that the hogs made $10 \mathrm{lbs}$. of pork to the bushel of corn while logging it down, September 10 th to October 25th.

The first week they were fed on ground corn and cob-neal, steamed, they inade the extraordinary amount of $20 \mathrm{lhs}$. of pork to one bushel of corn. Seeond week, weather colder, 15 $\frac{1}{2}$ lbs. ; third week, still colder, 10 lbs.; fuurtl week, weather colder yet, 6 $\frac{1}{2}$ lbs. of pork to one bushel of corn, and the first lot was sold.

The secund lot of hogs was fed five weeks in December, on the same food and in the same way as the first lot, the weather being same as in the lust week of November, and the corn averaged but $6 \frac{1}{2}$ lus. of pork to the bushel. In January, the weather being very cold, the corn returned but $1 \frac{1}{6}$ los. of pork per bushel; and when the temperature sank to zero and below, the coro returned nothing at all! Certainly a most instructive example, showing low the product ran down from 20 lbs, to the bushel to nothing, from the influence of cold alone, and alemonstrating beyond all doubt the a lvantage and the necessity of warmth and shelter.

Although incginlar, I will here also insert a remarkable experiment by S. M. Wherry, Slippensburg, Pat, and communicated to the Practic el Furmer, December, 186\%. Here the olject was grouth, not fat; and this practical experiment is viluable in severul particulars. Ten pigs of one litter, Berkshire brced, were fed in pairs, having heen equalized as near as possible. They wree twelve weeks and four days old at the commencement of the experiment, which continned eight weeks, or fifty-six days.

The first pair gained from five bushels of old shelled corn at the rate of $84 / 10$ lbs. per day, making 94 lbs. of pork, or $18 \%$ lus. from one bushel of corn.

The second pair ate 280 pounds, (or 5 bushels), of old corn, ground into meal and cooked, gaining $91 \mathrm{lbs}$, or $18 \%$ lbs. of pork from one bushcl, but less than from the whole and raw corn!

The third pair cousumed $140 \mathrm{lbs}$. of meal and $280 \mathrm{lbs}$. of potatoes, and gained $93 \mathrm{ll}$ s.

The fourth pair, fed on $560 \mathrm{lbs}$. of cooked potatoes, macle a gain of $89 \mathrm{lbs}$; showing that conked potatoes, fed alone, bave a little less than half the value of corn.

The fifth pair, fed green corn in the ear, 350 lbs., or 5 bushels, reckoning $70 \mathrm{lbs}$. to the bushel, and they gained the very extraordinary amount of $100 \mathrm{lbs}$, or $20 \mathrm{lbs}$. of pork to the bushel.

During all this experiment, each pig consumed but $2 \frac{1}{2} l$ s s of 
corn per diem, or the supposed equivalent in potatoes or green corn. This experiment alone, without baing supplemented and con. firmed by others, is insufficient from which do draw a general application ; but, as tie writer observes, is cery suggestive, iadicat. ing that pigs not pushed, but steadily and molerutely fe.l, malit flesh insteal of fat, at the rate of of/100 lbs, daliy, and that, hidä so fed, they can do tacir own gginding and cooking with advantuge.

It is evident that the greater the number and the longer the ime experiments are continued, the higher is the probablity tuat ihey approach to a reliable and constant averige, and if we a lmit that the thirteen experiments here set forth, were madeon ad yuate numbers and continued a sufficient length of time, they should have gre:st weight in establishing a general rule, which, in this case, would be that one bushel of corn, (or $56 \mathrm{lbs}$. of corn), fed on tlı? ear, returns, under ordinary circumstances, ten pounds of pork. But, intending to be cautious and moler:te, we shall assume, for comparison and ealculation, that one bushel raw and whole corn makes 9 lbs. of pork.

\section{RAIV MEAL,}

is supposed to increase in value over raw corn to the extent of 33 per cent; this is the opinion and statement of the Shakers of Lebanon, New York, after a trial of thirty years. If this increase be true, then, accorling to our basis of 9 lbs. of pork to one bushcl of corn, the corn, when ground, should make 12 lbs. of pork. This arrees with an experiment of Mr. Thomas Eilge, making 60 lbs. of pork from five bushels of meal.

And this rate of return coinciles with two elaborate and extended experiments-one in England and one in this country.

I give here the result of these experiments by Prof. Miles, of the Michigan Agricultur.l College, and by Mr. Lawes, of Rothamstead, Englan 1; and a full account of these very interesting and instructive experiments by Prof. Miles may he found in the "Obio Agricultural Report for 1863," and that of Mr. Lawes in the "Journal Royal Agricultural Society of Eugland," vol. xiv.

The experiment of Prof. Miles commenced May 21, and encled December 15 th, embracing a period of 203 days, or 29 weeks, and was mate on six grade Essex pirs, two weeks old, and from the same litter, and were divided into two pens of three pigs eacl. During the first few we'ks they were fet on a mixerl diet of milk, meal, and a portion of roots, and therefore we select the last period of 20 weeks, during which they were fed exclusively on corn meal. The three best pigs, one from pen $\mathbf{A}$ and two from 
pen B, were killed December 15th, and averaged $145 \mathrm{lbs}$. each ; and, deducting the original weight at the commencement of the experimont, each gained in the total period of 203 days $141 \mathrm{lbs}$. or $69^{1 / 100}$ lbs. per diem-during a part of this time, (8 weeks), being fed on a mixed diet. One of the pigs from pen $B$ having died, the other two were fed for 20 weeks on corn meal, and in 140 days gained $205 \frac{1}{2} \mathrm{lbs}$., or $98^{59} / 100 \mathrm{lbs}$., each pig, over their original weight, and at the rate of $73^{1 / 100}$ per diem for this period. In the 20 weeks $935 \frac{1}{2} \mathrm{lbs}$. of meal were consumed, equal to $16^{7} /{ }_{10}$ bushels of corn, and giving a return of $12^{3} / 10 \mathrm{lbs}$. of pork for each bushel, and requiriug $4 \frac{1}{2}$ lbs. of meal to make one of pork.

The expiriment of Mr. Lawes, of England, commenced February $2 \mathrm{~d}, 1850$, with 36 selected pigs in twelve pens, and were fed on several prescribed dictaries. The pigs were 9 to 10 months old, and at the time of selection differed among themselves but a pound or two, and when the experiment began averaged $143 \frac{1}{2}$ lbs., but a fraction less than those of Prof. Miles when his were killed, and the two might be considered in the light of a continuous experiment-Lawes beginning were Miles ended.

We select for investigation and comparison pen No. 5 , contain. ing three pigs, averaging $143 \frac{1}{2}$ lbs., because they were fed exclus ively on corn meal.

The experiment lastel 8 weelis, or 56 days, during which time each pig consumed $362 \mathrm{llbs}$, or $6^{46} / 50$ bushels of meal, and $6^{46} / 100$ lus. daily, and gaining $79^{68} / 20 \mathrm{nl}$ lls. of weight, or $1^{42} / 100$ lbs. per diem, and at the rate of $12 \mathrm{lbs}$. per bushel; a very remarkable a rreement hetwixt Edye, Miles, and Lawes.

An analysis of the experiments, bnth of Miles and Lawes, shows very clearly a rapid decrease in the rate of consumption of food to a given weight of animal as it fattens; and, although less food is eaten, it takes more of it to produce one pouncl of increase, so that, as the animal approaches his maturity of fatness, or, as it is termed in England, "ripeness," he may reach a point where the return in pork will not pay for the corn consumed. This point should be watched for and the pig at once sent to market.

At the conclusion of Miles' experiment, the pigs insreased less than two per cent in a week.

Prof. Miles remarks of his experiments :

"In the manufacture of pork the best return of the focd consumed will unlonbtedly be obtained by liberal feeding during the early stages of growth; and we cannot reasonably avoid the con. clusion that the same rule is applicable to all animals reared for the purpose of the butcher. 
"As animals are employed to convert the vegetable products of the farm into animal products of greater value, the greatest profit in fattening may reasonably bə expected from liberal feecling during the period of growth, in which the organs of nutrition are capable of converting the largest amount of material into animal tissues in a given time."

And Mr. Lawes established by his experiment " that the larger the proportion of nitrogenous compounds in the food, the greater the tendency to increase in frame and flesh; but that the maturing or ripening of the animal-in fact its fattening-depended very much more on the amount, in the food, of certain digestible non. nitrogenous constituents."

And this accords perfectly, I believe, with all experience.

\section{STEAMED OR BOILED CORN.}

I find a number of experiments in which steamed or boiled corn entered as part of the fool, for longer or shorter times, and mixed with other things, and only three experiments conducted wholly on boiled corn; one by Clay, gaining $14 \mathrm{lbs} .7 \mathrm{oz}$. of pork from a bushel; one by Van Loon, of Illinois, who obtained 18 lbs.; and the other from Montgomery county, Indiana, giving a fraction less than $12 \mathrm{lbs}$. of pork to the bushcl of corn; and all three give an average of a little less than $15 \mathrm{libs}$.

The Indiana experiment has most of the elements of time and numbers to make it reliable, and I give some analysis of it.

Eight pigs from one litter were put in a pen when one week old and fed nine montis, consuming $220 \frac{1}{2}$ bushels of corn, and gaining $2,644 \mathrm{lbs}$. of pork, averaging a gain of $330 \mathrm{l}$ lbs. each pig, or $11 / 5$ lbs. each per day for the whole period; and the following tabular statement shows the amount of corn fed during each month, the gain in weight, the number of pounds of pork made to one bushel, and the amount of corn required to make one pound of pork:

\begin{tabular}{|c|c|c|c|c|c|c|}
\hline \multicolumn{3}{|c|}{ No. of Month. } & $\begin{array}{c}\text { Amount } \\
\text { consumed. }\end{array}$ & Totalgain. & $\begin{array}{c}\text { Pounds of } \\
\text { pork per } \\
\text { bushel. }\end{array}$ & $\begin{array}{l}\text { Pounds } \\
\text { corn to one } \\
\text { pound port }\end{array}$ \\
\hline \multicolumn{3}{|c|}{ 1st month. } & $\begin{array}{c}\text { Bushels. } \\
15\end{array}$ & $\underset{168}{\text { Pounds. }}$ & 11.20 & 5. \\
\hline $\begin{array}{l}2 \mathrm{~d} \\
3 \mathrm{~d}\end{array}$ & 16 & & 24 & $2 \% 4$ & 9.33 & 6. \\
\hline $\begin{array}{l}3 d \\
4 \text { th }\end{array}$ & “ & ........ & $26 \frac{1}{\frac{1}{a}}$ & 272 & 10.30 & 5.43 \\
\hline $\begin{array}{l}4 \text { th } \\
5 \text { th }\end{array}$ & “ & $\ldots \ldots \ldots$ & 27 & 316 & 11.76 & 4.78 \\
\hline 5 th & $"$ & . $\ldots \ldots \ldots \ldots \ldots \ldots$ & $29 \frac{1}{8}$ & 35 & 11.96 & 4.68 \\
\hline 6 th & $"$ & $\ldots \ldots \ldots \ldots \ldots$ & 27 & 360 & 13.30 & 4.21 \\
\hline 7 th & " & n............. & $26 \frac{1}{9}$ & 350 & 13. 20 & 4.20 \\
\hline 8th & $"$ " & $\ldots \ldots \ldots$ & 26 & 327 & 12.60 & 4.40 \\
\hline \multirow[t]{2}{*}{9 th } & “ & ........ & 21 & 275 & 13.00 & 4.30 \\
\hline & & & & Average & 11.85 & 4.77 \\
\hline
\end{tabular}


Observe how regular is the increase in weight up to the eighth month of their age, when they averaged $241 \frac{1}{2}$ lbs-a regular decrease in the amount of food from the sixtl month of feeling, and a diminished quantity of corn to make one pound of pork, instead of an increase, as in Miles' and Lawes' experiments, which goes to corroborate what we have already said, that we meet with some unaccountable anomalies which, as yet, we are unable to reluce to any uniform rule. Perhaps these pigs had not yet reached their full capacity of fatness.

I ald here two extracts, one from "Eveuing Discussions" at the recent New York State Fair, 1867; subject: "Cooking Food for Domestic Animals."

Hon. G. Geddes, of Syracuse, New Yurk, said : "He had thoroughly proved, years ago, that cooking, independent of grinding, at least doubled the value of fcod."

"George A. Moore, of Erie county, New York, said he had fully s.tisfied himself that the value of food was tr pled by cooking."

I quote from "Transactions of the Americin Institute, 1864." Prof. Mapes says: "The experiment often tried has proved that 18 or $19 \mathrm{lbs}$. of cooked corn is equal to $50 \mathrm{lbs}$. of raw corn for hog feed, and that Mr. Masnu, of New Jersey, found that pork fed with raw grain cost $12 \frac{1}{2}$ cents per pound, and that from conked corn $4 \frac{1}{2}$ cents."

\section{COOKED MEAL.}

I find here, as in other cases, much of assertion, but backed by more of experiment; some claimin , on apparently good grounds, that grinding and cooking the meal thoroughly, doubles the value of the raw corn.

Rejecting here, as elsewhere, the many mixed and irregular experiments, we find that Clay obtained $17 \frac{1}{2} \mathrm{lbs}$. of pork from a busnel of corn so prepared; Marsh, of Glen's Falls, New York, $16 \frac{1}{3}$ lbs.; A. G. Perry, $18 \mathrm{lbs}$; Thomas I. Edge, Chester county, Pi., $16^{3} / 5$ lbs.; Nathan G. Morgan, New York, 20 lbs. ; Buckingin.m of Illinois, 20 lus.; Jonathan Talcott, Rome, New York, $17 .^{92} / 100$ lbs.; Robert Thatcher, Darby, Pa., made two experimentsone on five very or linary pigs, getting $16^{8} /{ }_{10} \mathrm{lbs}$.; the other on five superior Chester pigs, and gained $17^{44} / 100 \mathrm{lbs}$. from a bushel of covked meal, and remarks: "The surprising gain for food cons'zmed was the result of very careful feeding, clean and warm beddin?, and a tight house."

The average of all these experiments is $17^{84} / 100 \mathrm{lbs}$. per bushel. David Anthony, of Union Springs, New York, convinced him. 
self by experiment, that when corn fed in the ear was worth 62 cents, ground into meal it was worth 87 cents, and ground into meal and cooked, one hundred and eighteen (118) cents, the last being 91 per cent better than raw corn.

Fro.n an examination of the records at my command, I think that, taking the return of pork from a bushel of corn at nine p sunds, there can be no doubt that corn ground into meal and fed, increases in value about 33 per cent over corn fed in the ear. That thorougbly steaming or cooking the whols corn, raises its value to but little less than that of cooked meal, which I estimate at 66 per cent over raw corn fed in the ear.

I arrive at this conclusion, not only from the experiments I have herein set forth, but from an examiuation of quite a number not here given, on account of their mixed and irregular methods. It is true that grinding, steaming, or cooking the corn can in no wise add a single atom to the elements already existing, and raises its value only by rendering the whole nutritive matter available by valsing it more soluble and of easier digesticn, so that the maxinum of nutrition is more readily and certainly obtained.

I conclude that nine pounds of pork from a bushel of raw corn fed in the ear, twelve pounds from raw meal, thirtcen and a half pounds from boiled corn, and sixteen and a half pounds from cookel meal, is no more than a moderate average the feeler may expect to realize from a bushel of corn under ordinary circumstances of weather, with dry and clean feeding pens; All this is within the amounts we have shown to be probable and attainable upon our chemical basis.

Higher percentages have been frequently obtained in practice than any we shall now assume as our basis in making practical application of our researclies. And if it be true that what has once been done can be done again, there is great encouragem nt for the feeder to study and master the circumstances that will give the higher results. And in this connection, it is important to consider that animals live constantly in a medium colder than them. selves for the greater part of th ' year, and that the lower tenjperature continually abstracts and wastes animal heat which, in the fattening process, nust be maintained in proportion to the temperature in which they life, and that this heat is obtained from the food which, under other circumstances, would be transformed into fat and stored up in the tissues.

And we can readily perceive that warmth and shelter from the vicissitudes of the weather is not only inportant, but almost in. 
dispensabie, and without them we cannot expect the highest return for the food cunsumed; and of the truth of this the Duncan's Falls experiment is a most striking and instructive example.

Having established the fact from chemical elements, that 16 to $19 \mathrm{lbs}$. of pork are possible, and tliat 18 and $20 \mathrm{lbs}$, are not unfre. quent in actual practice, under the circumstances indicated, we shall not be deemed extravagant if we take $15 \mathrm{lhs}$. per bushel as the basis of our calculations in ascertaining per pound the

\section{COS̃ OF PORK,}

which, it is obvious, must depend upon the cost of corn and feeding: and in ascertaining this, we intend assuming such a scale of wages as would in any part of the country secure the necessary labor, supposing, as we do, that it is all to be bired, and that the laborers board themselves; and if our estimates are too high, or if the farmer, with his own labor and teams, can rednce the cost below what we state, it will be easy to correct our tables and make them conform to the reduction, wnich would only increase the farmer's margin for profit.

We assume the wages of a hired man at $\$ 2$ per day, and two horses with plow or wagon to bc worth the same, or four dollars a day for the whole

TABLE NO. 3.

Showing the cost of raising an acre of corn; one man and team plowing two acres per day:

One acre plowed costs............................. $\$ 2.00$

Harrowing 8 acres a day, 1 acre costs.................... 50

Planting with machine 8 acres, 1 acre costs $\ldots \ldots \ldots \ldots \ldots \ldots \ldots . \quad 50$

Seed for 1 acre ................................... 30

Double shovel plowing, or clltivating 6 acres-1 acrc costs $66^{2 / 3}$ cents, or cultivating one acre three times............... 2.00

Deeper plowing, hoeing, extra labor, or rent, as the farmcr chooses, or as the season demands................... 3.00

Total.................................. $\$ 8.30$

whether raising 35 or 60 bushels to the acre, the labor being the samr-that is, the farmer is obliged to bestow upon his crop during the season a certain amount of labor.

Whatever difference of opinion about the distribution of the items here, the sum total for raising tise crop I believe to be ample and ought to command a return of 60 bushels. 
TABLE NO. 4.

\section{Cost of Gathering and Fecding.}

Husking $33 \$$ bushels per day to the hand, at $\$ 2.00 \ldots \ldots 6$ ets. per bu Wages of unan and team, at $\$ 4.00$ per day, hauliug and

eribbing 150 bushels....................... ets. per bu, One man with steam power will shell, grind, steam, and

feed 75 bushels per day, wares \$2.00; fifteen bushels

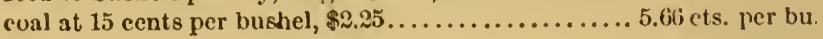

\subsection{6}

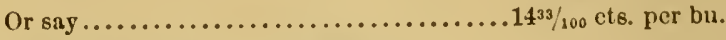

which we will take for our future tables.

TABLE NO. 5 .

Shows cost of corn per bushel at $\$ 8.30$ per acre, and raising 35 to 60 buslicls per atcie:

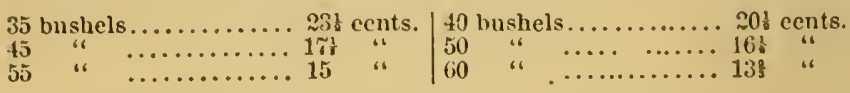

By adding the cost of grinding, steaming, and fecling, to that of raising and cribbing, we liave the total cost of the corn in

TABLE NO. 6 .

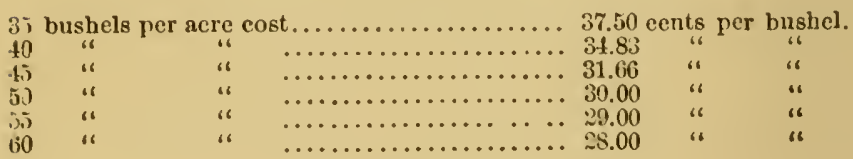

TABLE NO. $\%$

Showing the gross value of a bushel of corn when fed on the cob, or in the form of raw meal, hoiled corn and cooked ineal,

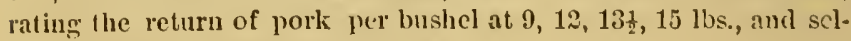
ling from 4 to 10 cents per pound:

\begin{tabular}{|c|c|c|c|c|c|c|c|c|}
\hline \multirow{2}{*}{$\begin{array}{l}\text { Pounds of pork from } 1 \\
\text { bushel of corn. }\end{array}$} & \multicolumn{7}{|c|}{$\begin{array}{l}\text { Value of pork from } 4 \text { to } 10 \\
\text { cent } 8 \text { per pound. }\end{array}$} & \\
\hline & 4 & 5 & fi & 7 & 8 & 9 & 10 & \\
\hline $\begin{array}{l}\text { On the ear ........ } \\
\text { Raw meal } \ldots \ldots \ldots \ldots 12 \\
\text { Boiled corn } \ldots \ldots \ldots 18 \text {. } \\
\text { Cooked meal... . . } 15\end{array}$ & $\begin{array}{l}36 \\
48 \\
54 \\
60\end{array}$ & $\begin{array}{l}45 \\
60 \\
67 \frac{1}{2} \\
75\end{array}$ & $\begin{array}{l}54 \\
\% 2 \\
81 \\
90\end{array}$ & $\begin{array}{r}63 \\
84 \\
94 \\
103\end{array}$ & $\begin{array}{r}7: 2 \\
96 \\
108 \\
1: 0\end{array}$ & $\begin{array}{c}81 \\
108 \\
1 \geqslant 16 \\
100\end{array}$ & $\begin{array}{r}r 0 \\
120 \\
135 \\
150\end{array}$ & 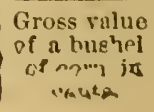 \\
\hline
\end{tabular}


TABLE NO, 8.

Showing cost per pound of pork, the number of bushels of corn per acre, cost per busshel of ruising and fecding, and return in pork-being given according to our calculations :

\begin{tabular}{|c|c|c|c|c|c|c|c|c|}
\hline \multicolumn{2}{|c|}{ Bushels per uere.. } & 35 & 40 & 45 & 50 & 55 & 60 & \\
\hline \multicolumn{2}{|c|}{ Cost per bushel... } & 37.50 & 34.83 & 31.66 & 30.00 & 29.00 & 28 & \\
\hline $\begin{array}{l}\text { Pounds of } \\
\text { pork return- } \\
\text { ed per } \\
\text { bushel. }\end{array}$ & $\left|\begin{array}{c}0 \\
1: 2 \\
131 \\
1.3\end{array}\right|$ & $\begin{array}{l}1.16 \\
3.12 \\
2.75 \\
2.50\end{array}$ & $\begin{array}{l}3.87 \\
2.50 \\
2.58 \\
2.37\end{array}$ & $\begin{array}{l}3.51 \\
2.61 \\
2.34 \\
2.07\end{array}$ & $\begin{array}{l}3.33 \\
2.50 \\
2.22 \\
2.00\end{array}$ & $\left|\begin{array}{l}3.23 \\
2.42 \\
2.15 \\
1.93\end{array}\right|$ & $\begin{array}{l}3.11 \\
2.33 \\
2.07 \\
1.87\end{array}$ & $\left\{\begin{array}{c}\text { Cost of pork in } \\
\text { cents, and } 1 / 100 \\
\text { of a cent. }\end{array}\right.$ \\
\hline
\end{tabular}

TAULE NO. 9 .

Showing the total amount of pork per acre, the number of bushels of corn and return of pork per bushel, being given according to our calculations:

\begin{tabular}{|c|c|c|c|c|c|c|c|}
\hline \multirow{2}{*}{$\begin{array}{l}\text { Pounde of pork from } \\
\text { one bushei of corm. }\end{array}$} & \multicolumn{6}{|c|}{ Bushels of corn per acre. } & \\
\hline & 35 & 40 & 45 & 50 & (5i) & 60 & \\
\hline 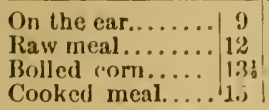 & $\begin{array}{l}315 \\
4.0 \\
47.3 \\
5,35\end{array}$ & $\begin{array}{l}: \% 60 \\
480 \\
540 \\
6(0)\end{array}$ & $\begin{array}{l}405 \\
540 \\
607 \\
675\end{array}$ & $\begin{array}{l}450 \\
600 \\
675 \\
750\end{array}$ & $\begin{array}{l}4: 5,5 \\
660 \\
742 \\
825\end{array}$ & $\begin{array}{l}540 \\
720 \\
810 \\
900\end{array}$ & $\begin{array}{l}\text { Total pounds of } \\
\text { pork per acre. }\end{array}$ \\
\hline
\end{tabular}

If we find the price per pound of pork in Table No. 8 corresponding to any particular yield of corn per acre and pork per bushel, and deduct it from the market price at any given time, and multiply by this difference the number of pounds of pork obtained from the bushel, we have the net profit on a bushel of corn. Thus, at 45 bushels per acre and $13 \frac{1}{2}$ lbs. per bushel, we find the enst of pork per pound to be 2.34 cents. Supposing pork to be selling at 6 cents per ponnd, the difference is 3.66 cents; multiplying $13 \frac{1}{2}$ lhis. (the yield per bushel), hy which we get 49.4 cents as the profit per bushel of corn. If, as before, we find the price of pork in Table No. 8, and deduct from market price, and multiply by this difference the number of ponnds of pork per acre, as found in Table No. 9, corresponding to any given yield of corn per acre, and pork per buslıel, we have the net profit per acre from pork. Thus, we find lyy table No.9, at 45 bushels per acre and $13 \frac{1}{2}$ lbs. per luushel, the amount of pork per acre to be $607 \mathrm{lbs}$. Multiplying this number of pounds by 3.66 cents the difference between cost and selling price, we have $\$ 22.21$ as the profit per acre of eorn.

We have already satisfactorily shown from chemical data aluove 
that, after allowing a sufficiency of the elements to restore the daily waste and keep a hog in good condition, there is enough in the corn to hring him from 0 to $300 \mathrm{lbs}$, at the rate of $15 \mathrm{lbs}$. of pork per bushel of corn. And practice has shown that there is more than we have assumed in our calculations, and adhering to our maximum of $15 \mathrm{lbs}$. as one we bulicve to be casily attainable, and supposing also that the feeder will strive for the higlier rasult, we have prepared a table to show what profit be may expect for his corn with good cultivation, and getting a return of $151 \mathrm{ls}$. of pork from one bushel of corn.

TABLE NO. 10 .

\begin{tabular}{|c|c|c|c|c|c|c|c|}
\hline \multirow{3}{*}{$\begin{array}{l}\text { Selling price of } \\
\text { pork per pound in } \\
\text { cents. }\end{array}$} & \multicolumn{7}{|c|}{$\begin{array}{l}\text { Whole cost of corn per bushel according to product } \\
\text { per acre, at- }\end{array}$} \\
\hline & 35 & 40 & 45 & 50 & 55 & 60 & Bushels. \\
\hline & $\begin{array}{r}\text { Cents. } \\
3.50\end{array}$ & 34.83 & 31.66 & 30.00 & 29.00 & 28.00 & $\begin{array}{l}\text { Cost per } \\
\text { bushel. }\end{array}$ \\
\hline 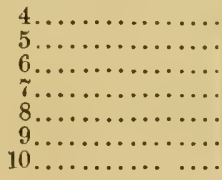 & $\begin{array}{r}2: .50 \\
37.50 \\
52.50 \\
67.50 \\
82.50 \\
97.50 \\
110.50\end{array}$ & $\begin{array}{r}25.17 \\
40.17 \\
55.17 \\
70.17 \\
85.17 \\
100.17 \\
115.17\end{array}$ & $\begin{array}{r}28.34 \\
42.34 \\
58.34 \\
73.34 \\
88.34 \\
103.34 \\
118.34\end{array}$ & $\begin{array}{r}30.00 \\
45.00 \\
60.00 \\
75.00 \\
10.00 \\
105.00 \\
120.00\end{array}$ & $\begin{array}{r}31.00 \\
46.00 \\
61.00 \\
76.00 \\
91.00 \\
106.00 \\
121.00\end{array}$ & $\begin{array}{r}32.00 \\
47.00 \\
62.00 \\
7 \% .00 \\
92.00 \\
10 \% .00 \\
122.00\end{array}$ & $\begin{array}{l}\text { Net pro- } \\
\text { fit per } \\
\text { bushel. }\end{array}$ \\
\hline
\end{tabular}

It appears from our first and second tables, giren in a former part of this paper, that, from the chemical elements, there is but little difference in the fattening value of several of the foods there given, but, in so far as they contain more of the phosphates and flesh formers than corn, they could be very advantageously fed to young and growing animals; but the cost of producing equal weights of these must, after all, determine their economic value in the fattening process.

And now, having satisfactorily to oursclves, at least, set forth and established the close agreement of theory with the best practice, not by guesses and loose opinions, but hy solid facts and experiments we might here leave the subject for each one to sccure the results we have shown to be attainable by the methods best suited to his own circumstances and according to his own notions. But, in consequence of important questions which now arise, we must pursue the subject a little farther, even if it lead us, for the moment, from all well-establialied fucts iuto the ficld of hypothesis and conjecture, for we have not here any recorded experiments to assist us in determining a question of much practical importance- 


\section{THE RIGHT AGE AT WHICH TO FATTEN A HOG ?}

Whether it is better to keep him as a store or stock animal, in moderate orcler and growing condition, on grass and clover with a little corn during winter, until he is maturel in growth, at 12, 18 , or 20 months old, and then in three or four months feed him up to 400 or 500 pounds, or to winter him only and fatten him in the spring; or is it best to push the pigs from birth and feed them up to $300 \mathrm{lbs}$. at nine or ten months old?

In order, if possible, to get some light on this point of our investigation, let us take two pigs from the sime litter, as near alike as possible, subject them to the same truatinent and the same food, terminating one experiment at nine montiss and the other at eighteen. Then with pigs littered, say April 1st, let them run with their nother on grass and clover until October 1st, a period of six mouths, or 183 days. It will be reasonable to assume they will make three-fourths of a pound of daily growth and increase for that period, or weigh $138 \mathrm{lbs}$. each.

We will now take pig A and put him up to fatten, and, as three months or thirteen weeks are amply sufficient to ripen a $\mathrm{Log}$, we will full feed him that length of time, or 92 days. We also desire to bring him up to $300 \mathrm{lbs}$; and, as he already weighs $138 \mathrm{lbs}$., there remain 162 to be addel, and, if our estimate of $15 \mathrm{lbs}$. of pork from one bushel of corn ground into meal and boiles be correct, he must eat $10 \%$ bushels of corn and get a daily increase of one and three-fourths (18) pounds, and so, having arrived at 300 lis., we dispose of him.

Pig $B$, also, at the end of six months, or the first of October, weighs 138 lbs., same as pig A, but, instead of being put to fatten, we wish to continue hin to May first, or 212 days, and, gaining at the same rate as before-that is, three-fourths pounds daily - as from April to October. During this period, from October to May, he consumes $11 \frac{1}{4}$ bushels of corn, gains 159 , and then weighs 297 lbs. Again, he pastures from May to Oetober, gaining, as before, 138 lbs., and now, at October first, when he is put up to fatten, weighs $435 \mathrm{lbs}$, and, being fed for the same period as was $\mathbf{A}$, or 92 days, and making the same increase, he now weighs 594 lbs, and has eaten altogether a little over 22 bushels of corn and twelve months of pasture. Pig $A$, for six months pasturage and $10 \%$ bushels of coln, returns $300 \mathrm{lhs}$. of pork, while pig $\mathrm{B}$, for twelve months pasturage and 22 bis'iels of corn, returns but $594 \mathrm{lbs}$. of pork-being a difference of six (6) pounds of pork and one-fifth of a bushel of corn in favor of feeding two hogs like A rather 
than one as B, making the same amount of pork and returning the money invested in one-half the time.

From the fact that both Lawes and Miles found, as the hog approached ripeness, or full maturity of fatness, the quantity of corn to make a pound of pork increases, and the time also, it may be that our suppositious cases are very near the truth; $I$ think they are, and that it will take less food to make $600 \mathrm{lbs}$. of pork from two animals than from one. And the rates of increase and total weights given of the animals is rather strengthened and corroborated by the fact that from an examination of the weights given of several humbled extra heavy hogs (upwards of 350 ,) of the age of 20 and 22 mouths, very few reached $600 \mathrm{lbs}$, and none made an increase of one pound a day for that whole period.

There are many experiments proving that hogs of 18 to 22 months frequently increase lluring the fattening process at the rate of 21 to 3 lhs. a dily, and even more; and that young hogs are very often made to weigh $300 \mathrm{lbs}$. and over at the age of 9 to 10 months.

There is no doubt a certain proportion betwixt muscle and fat while feeding, which will be found to give the most advantagcous results ; but it is so apparent that, to obtain great weight in any animal, we ought to have a good supply of bones and muscle to begin with, and a sufficient frame-work on which to build and lay the fat, that I think it would be advisable to devote the first few mouths of the pig's life to growth rather than for fat-making, and to this end S. M. Wherry's experiment, on page 183 furnishes a good example. And it will be well to remenber that Miles' pigs, with an insufficient frame-work to carry more, were ripe at seren months old, with a weight of 145 only pounds, having been pushed from the start.

Having shown how much pork is to be expected from a bushel of corn, prepared and fed in varions ways, we will devote a brief space to considering the expense of preparation. It will be observed that in estimating the lowest cost price of pork, we assumed 15 los. as our maximum return from a bushel of corn.

But in obtaining this result we have shelled, ground and cooked our corn meal with steam power, and it may be said, with truth, perhaps, that this can only be applied economically on a large scale-say to feeding upwards of 250 head-to feed less would hardly justify the necessary outlay for machinery and apparatus, and we must try some other plan more suitable for smaller operations.

From an examination I am satisfied it will cost upon an average 15 cents to have corn slyelled and ground, including toll and trans- 
portation to and from the mill. That is to say, taking our yield of nine pounds of pork from raw corn, and 12 from raw meal, we must get 15 cents from the three additional pounds, or five cents per pound for the pork, to pay the cost of grinding.

It is obvious that this pork must sell at some price greater than this to afford any profit on the three pounds so produced, and to gain even five cents per bushel above the product, and nine pounds per bushel, we must get 6 cents per pound for the pork. But now, having our corn ground into meal, let us proceed to cook it, which I estimate will cost seven cents per bushel on a moderate scale, with simple apparatus; and 15 cents, the cost of grinding, added to seven cents, the cost of cooking, equals 22 cents.

From corn so prepared, we expect a returu of 15 lbs. of pork per bishel of corn, and a gain of six pounds over raw corn, producing but nine pounds. These six pounds have cost 22 cents, or 3 s cents per pound, and it is evident that, for every cent per pound above this cost that the pork brings, we gain six (6) cents more than when getting but nine pounds per bushel. Then, at $6 \frac{2}{2}$ cents for pork, our prefit would be 18 cents for these six additional pounds per bushel.

Suppose now, instead of incurring the expense of grinding, that we steam or cook the whole grains of corn, at the same cost as the meal-seven cents per bushel-and gain thereby $4 \frac{1}{2}$ lls. over the product of raw corn (to wit: nine pounds, then, at 6 a cents per pound for pork, our profit would be 23 cents per bushel for these $4 \frac{1}{2}$ additional pounds, and in like proportion for any higher selling price for pork.

In all calculations of expense throughout this paper, we bave intended to make ample and liberal estimates.

It is plain, from a comparison of the above statements, that, although getting but $13 \frac{1}{2} \mathrm{lbs}$. of pork from a bushel of boiled or cooked corn, it is yet the most economical method of preparing the corn on a moderate scale, and affords not only a possibility, but a high probability, of a larger return than we have given.

$\Delta \mathrm{nd}$, fortunately the apparatus required is simple and inexpensive, for any vessel with a capacity to turn into steam 26 gallons of water per hour is sufficient, if we assume that corn has the same capacity for heat as water, to raise 10 bushels of corn to the boiling point in one hour and keep it there, and furnish a daily ration for 60 hogs. But it is evident the corn must be kept some time at the temperature indicated to cook it. No doubt on many farms there already exist the pans and brick arehes used in the making of sorghum molasses; and these pans, with some alterations and 
inexpensive additious, would, no doubt, answer an admirable purpose. So, also, will a l.jre kettle set in an arch, answer to eook enrn for 10 to 30 hogs. The corn, whetlrer cooked in the pans or kettle, should be shelled and placed in trays with stout wire hottoms just close enough to hold the grains of corn; and, placing these trays, if need he, one on top of the other, just above the water in the pan or kettle, let all be covered and steam away. I thiuk that for about 75 or 80 collars, an apparatus on this principle can be male, sufficient for 150 logs. In any apparatus for cooking or steaming the food, one square foot of pan or kettle exposed to the fire, is the minimum space capable of evaporating one gallon per hour $-1 \frac{1}{8}$ feet is better.

It is propable the corn conld be ground on the farm with horsepower, cheaper than we have estimated, if the feeder will invest in a mill and necessary power.

Opinions differ as to any real value in feeding the col ground with the meal; some altaching great value to the method, others rejecting it altogether.

Chemical analysis of the corn-col) gives six to ten per cent of matter that may be rendered, by long maceration and boiling, capalle of assimilation by the animal.

I myself believe there is not nutriment enough in the cob to pay for getting it out; but an occasional feed of cob meal would be of service, for in the fattening process, a certain amount of inert matter seems not only to be benefieial, but to he absolutely requirel by the hog, and it is, no doubt, this instinctive want and necessity, that induces the log to cat coal, rotten wood, and even clay and dirt.

Having now considered the various methods of preparing and feeding eorm, there yet remains one subject to be discussed which is of too great importance to be ignored or overlooked in any scheme of pork-making, I allude to

\section{THE VALUE OF GRASS AND CLOVER.}

We have alrealy mentioned it; but, in the absence of any carefully conlueted experiments on this point, it is somewhat difficult to determive the pork-naking value of grass and clover, as compared with corn. I find great differenees of opinion as to the number of hogs an acre of arooci grass or clover will support during the seas'u; the number varying from three to six-the ligher number being assigned to an acre of good elover.

Of course the number must depend upon the quantity of grass or clover, whether it be thick or thin, and also a good, moderate, 
or poor crop. In this dilemma let us see if theoretic statements will help us in the solution of this question.

We will assume, to begin with, that one acre, with a goorl set of timothy and clover, oceupying the ground in equal proportions, will give a product of $12,000 \mathrm{lbs}$. during the season. We think this a moderate estimate, for the reason that it requires less than one ounce of green food per month from each square foot during tive months of pasturage. Suppose the average of the logs, when turned on to grass, to be 125 lbs., and that it be the fact, as bas been frequently stated, that an animal requires three per ceut uaily of his live weight in dry food, or its equivalent in grcen food, to keep him in a growing and fattening condition, then $7 \frac{1}{2}$ liss. of grass and clover will be consumed by one hog daily from May to October, or 153 days, or $1,146 \frac{1}{2}$ Itss. during this whole period. Then it is evident the acre of grass and clover will support as many hogs as $1,146 \frac{2}{2}$ is contained in $12,000 \mathrm{lbs}$. (the product of one acre,) or 10 hogs, nearly! But we prefer to base our calculations on the data given in a previous part of this paper, that it requires one and one-third pounds of corn to maint.jin a hog of 150 lbs. in condition merely, and of course requires a corresponding portion of green food to do the same thing; and if, accorling to our Table No. 2, it takes 6.75 lbs. of clover to equal one of corn, then 1.33 lbs. of corn, (the amount to keep the hog in condition), requires nine pounds of green clover, or an equivalent, to supply the taily waste in the animal organism, and of course an additioual amount is necessary to increase the $\log$ in weight; and if we take the increase at one-half pound daily, then $6.75 \mathrm{lbs}$. more of clover is needed, or 15.75 altogether; but as timothy (of which an equal portinn of our green food consists), is in value to clover as 298 to 675 , a less amount, or eleven pounds, will suffice than if feeding clover alone. But as some ss wasted and trampled down, we think a daily allowance of fifteen pounds to each hog is nowe too much.

Fifteen pounds of green fool, whicl we have determined as the ration to sustain the hog and fatten him onc-lialf pound daiy, is contained in 12,000 lbs., (the product of one acre), 800 times, and would support one hog for 800 days, or $5^{1} / \mathrm{s}$ hogs one hundred and fifty-three days, or five months, from May to October, the period of pasturage. Omitting the fraction, our five hogs increasi $g$ onehalf pound daily for 153 days, we have a total return in pork of $382 \frac{1}{2}$ llss. from one acre of timothy and elover, and its value can be compared with the amount of pork produced from an acre of corn in Tuble No. 9. 
I estimate the cost of getting a good set of clorer and timothy at four dollars (\$t) per acere, and that we will have two seasons of pasturage from it and dividing this cost into two years it will be but two tollars for our 38.2 ths. of pork, or a fraction over hult a cent per pound; or, assigning to our grass and clover pork the lowest selling price in our tables, or 4 eents per pound, it gives us $382+>4=\$ 15.30$-and, levlueting the cost of the grass ant elurer, leaves us a net protit of $\$ 13.30$ for one acre of our pasture. Of course all this is lypothetical, and each one must determine for himself how nealy these ealculations are correct. I believe they are within the truth, and will be exceeded in actual practice.

If any one talies the trouble to compare the ralues of p.rk and corn on our data of 9, 1:, $13 \frac{3}{2}$ and 15 lbs. of pork from a busliel of corn, it will be found that, at nine pounds, one pound of pork must bring six and two ninths $\left(6^{3}, 9\right)$ times as much as one pound of eorn to make the pork equal in value to the corn-at 12 lbs, per bushel one pound of pork must bring $4 \frac{1}{2}$ times as much as one pound of corn-at $13 \frac{1}{\mathrm{l}} \mathrm{lbs}$. per bushel the pound of pork must bring $4^{1 / 20}$ times the price of the corm, and at $15 \mathrm{lbs}$. per bushel the pork requires to be $3^{3} / \mathrm{s}$ times the value of one pound of corn.

Finally, nfter a careful and somewhat extensive examinution and analysis of quite a number of experiments, regular and irregrular, of all the various methods of feeding corn, including a wide runge of country and seasons, I tind, upon the whole, that, amidst the apparently discrepant and contradictory statements, quite uniform and aecordant results lave been obtained under similar cirenustanees. And, notwithstanding the subtle intluences of life and the rital processes may continue to evade us, and may never be brought entirely under our control, and male subservient to our purposes, yet, aside from all this, we have the power of perfect command over many of those cireunstances, whieh do mdoubtedly exercise a most important inthenee orer the young and growing animal-such as fools in varions quantities, forms, and proportions, regular feeding, cleanliness, wamth, and shelter from the weather; and last, but not least, a judicious selection of the breeds and aptitudes best suited to our wants.

And I conclule, upon a review of the whole suloject, that it will pay to fatten hogs on eorn alone, when properly prepared, and it will be ensier and cheaper if a portion of the pork be made on grass and elorer.

Where the farmer prepares for pork-naking, and pursues it with systcm and regularity, I believe it will pay him better than to sell 
his corn, (no matter what be the market price), even at his own door. And especially I think will this be found true by those so situated as to be obliged to haul their corn any distance to market, which increases the eost of the corn 5 to 15 cents, aceording to the distance to be traveled.

My investigations have led me to some unexpeeted conclusions, but, having no theory to begin with, I have simply followed where truth seemed to lead, determined to collect and tabnlate fincts nnol he guided by them alone, avoiding all mere opinions and assertions.

If we have proved anything, it is, that it is possible and commaratively easy to get 50 per cent more for corn thatn we now do for all the millions of bushels fed to hogs in the process of porkmaking. Sustaining in this industry alone a loss of millions of dollars annually, the question of how much pork in a bushel of corn is not an iusignificant one.

It strikes me that the different State $\boldsymbol{\Lambda}$ grieultural socseties conld engage in no more benefieial work thun to arrest the enormous losses of our wasteful feeding processes, by the dissemination of correct information, and by a series of well-conducted experiments lend their powerful aid to elucidate so important a subject. 


\section{CHAP'LE TIX.}

\section{THE FIFECTS OF COLD ON FATTHNING SWINE.}

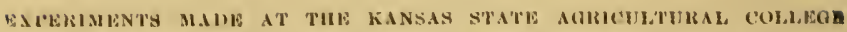

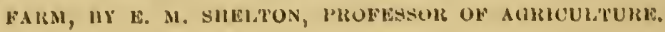

In the West, a very large proportion of all amimals kept for their flesh, are fattened during the most inclement season of the year, and they receire protection that is rarely sullicient to break the foree of the wintry blasts. In some eases, the eorrats, or feed-lots, are located in a belt of timber, a ravine, or a sink in the prairie, but the shelter is rarely suflicient to affect the temperature of the enclosure.

'I'his western plan of leeding has often been condemned on sentimental gromuds, but the finets that stoek has grenerally fed well under this plan, and the business of foeding has been protitable to the feeder, have prevented these objections trom having very great influence. With the object of establishing some faets hearing on this point, and having a relation to protit and loss, the experiments herein detailed were modertaken.

In the winter of $1880-1$, and again in the winter of $185: 3$, ten pure-lored Berkshire pigs of good pedigreo were seleeted. T'he ages of those employed in the ex. periment of $1880-1$ were as follows:

Pen No. 1. Farrowed April 12, 15\%!) Pen No. 4. Farrowed July 4, 1879

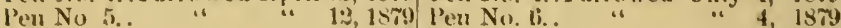

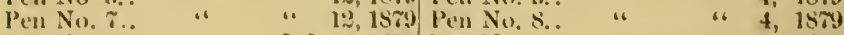

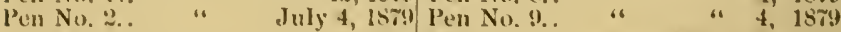
Pen No. 3.. " " "4, 1879 l'en No. 10. " Mureh 20 , isig

The lliree dutes represent three direrent litters.

'The ten subjected to experiment in the winter of $1882-3$ were of three clifferent litlers, all farrowed in November, 
1881, and so closely related on the side of sire and dam, as to be practically identical in blood. 'The pigs employed in both experiments, during the summer preceding, and up to the time the experiment began, were kept in a large pasture-field-mostly prairie grass, but containing a small proportion of orchard grass and alfulfa (lucerne) - receiving two ears of corn per pig each day. The pigs were a remarkably uniform lot, and of very excellent quality.

In both experiments, the pens numbering 1 to 5 , inclusive, were arranged in the basement of a warm stone barn, and jens 6 to 10 , inclusive, in an open yard on the south side of a close board fence, five feet high, but without other protection, except straw "nests," which were furnished both sets as neederl. A single pig ocenpied each pen, an arrangement necessary to the proper apportionment of feed, and distribution of the results of the experiment. It is safe to say, that the shelter afforded to the pigs kept in open yards was greatly superior to that ordinarily given to fattening pigs in the West.

In the first of these experiments, that of $1880-1$, in pens $1,2,5,6,7$ and 10 , shelled corn was exclusively fed; in pens 3, 4, 8 and 9, a ration of bran, in addition to the corn, was fed, the amount varying lint little from two pounds per dily. 'I'he bran wiss fed dry, or' mixed with water, to suit the tastes of the different pigs. At first this was eaten with apparent relish, lut as the pigs increased in ripeness they seened to care less for the bran, finally refusing it altogether, and about the eighth and nintli wecks, the bran ration was discontinued.

fin the experiment of 188\%-3, shelled corn alone was fed in all of the pens. In all the pens of each experiment the animals were fed all the corn they would cat, great care being takon that none was left orer in the troughs and wasterl, and equal care was taken that none should be insufficiently snpplied. 'The pigs were fed twice daily, at 8 A. M. and at 4 r. s., the feed being 
weighed out accurately to each pig at every feeding. If at the time of feeding the previous feed had not been consumed, the surplus was removed, and a proportionate reduction made in the amount of the next feed. All of the pigs receired whaterer water they required.

In order to see the effects of variations in temperature, the readings of Fahrenheit's thermometer, in the barn and at the pens in open yards, were recorded every morning at 8 o'clock in both experiments.

All of the pigs were weighed at the close of each week, a little before the time of the first feeding of the week following.

In table No. 1 is shown in pounds and decimals of a pound the weight of each pig at the beginning of the experiment, the total gain, the total gain per cwt., and the average gain per cwt. in the experiment made in 1880-1.

TABLE NO. 1 ,

8HOWING THE WEIGHT OF EACH PIG AT THE BEgINNING OF THE EXPERIMENT, AND AT THE CLOBE OF EACH WEEK, THE TOTAL GAIN, THE TOTAL GAIN PER CWT, OF EACB PIG, AND OF THE TWO SETS.

\begin{tabular}{|c|c|c|c|c|c|c|c|c|c|c|c|}
\hline \multirow[b]{2}{*}{ Dase. } & \multirow[b]{2}{*}{$\begin{array}{l}\text { Week of } \\
\text { Experi- } \\
\text { ment. }\end{array}$} & \multicolumn{5}{|c|}{$\begin{array}{l}\text { Pigs kept in warm pens } \\
\text { in the barn. }\end{array}$} & \multicolumn{5}{|c|}{$\begin{array}{l}\text { Pigs kept in open pens in } \\
\text { the yard. }\end{array}$} \\
\hline & & $\begin{array}{l}- \\
\mathscr{B} \\
-\end{array}$ & $\begin{array}{l}0 \\
0 \\
0 \\
0\end{array}$ & $\begin{array}{l}-7 \\
8 \\
0 \\
0\end{array}$ & $\begin{array}{l}\overrightarrow{0} \\
\mathbb{0} \\
\mathbb{2}\end{array}$ & $\begin{array}{l}-0 \\
0 \\
0 \\
0\end{array}$ & $\begin{array}{l}7 \\
8 \\
8 \\
0\end{array}$ & $\begin{array}{c}0 \\
0 \\
0 \\
-1\end{array}$ & $\begin{array}{l}0 \\
\mathscr{0} \\
\mathscr{0}\end{array}$ & $\begin{array}{l}7 \\
8 \\
0\end{array}$ & $\begin{array}{l}\stackrel{0}{8} \\
\stackrel{0}{0}\end{array}$ \\
\hline Nov. 1, ' 80 & $\begin{array}{l}\text { Begin' ing } \\
\text { of Exper't }\end{array}$ & 272 & 240 & 258 & 275 & 226 & 244 & $2: 29$ & 249 & 252 & 285 \\
\hline 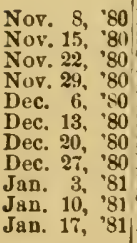 & $\begin{array}{l}\text { First..... } \\
\text { Second... } \\
\text { Third... } \\
\text { Fonrth... } \\
\text { Fifth. . } \\
\text { Sixth .... } \\
\text { Seventh. } \\
\text { Eighth... } \\
\text { Ninth .. } \\
\text { Tenth... } \\
\text { Eleventh. }\end{array}$ & \begin{tabular}{l|}
281 \\
296 \\
313 \\
331 \\
349 \\
36.5 \\
$3 \times 9$ \\
400 \\
413 \\
424 \\
435
\end{tabular} & $\begin{array}{l}257 \\
266 \\
282 \\
304 \\
323 \\
339 \\
359 \\
371 \\
381 \\
394 \\
404\end{array}$ & $\begin{array}{l}267 \\
255 \\
297 \\
319 \\
336 \\
356 \\
373 \\
390 \\
399 \\
410 \\
424\end{array}$ & $\begin{array}{l}294 \\
309 \\
325 \\
338 \\
357 \\
376 \\
3946 \\
409 \\
422 \\
429 \\
439\end{array}$ & $\begin{array}{l}238 \\
251 \\
273 \\
289 \\
305 \\
321 \\
340 \\
351 \\
359 \\
374 \\
35^{2}\end{array}$ & $\begin{array}{l}253 \\
263 \\
257 \\
304 \\
323 \\
347 \\
356 \\
373 \\
382 \\
334 \\
401\end{array}$ & $\begin{array}{l}239 \\
245 \\
259 \\
255 \\
288 \\
3045 \\
321 \\
336 \\
346 \\
3.57 \\
366\end{array}$ & $\begin{array}{l}260 \\
269 \\
292 \\
310 \\
317 \\
3: 11 \\
339 \\
34= \\
357 \\
366 \\
372\end{array}$ & $\begin{array}{l}259 \\
278 \\
293 \\
308 \\
320 \\
338 \\
316 \\
355 \\
356 \\
356 \\
369\end{array}$ & $\begin{array}{l}292 \\
313 \\
330 \\
352 \\
362 \\
387 \\
392 \\
403 \\
393 \\
407 \\
409\end{array}$ \\
\hline $\begin{array}{r}\text { Total gain. } \\
\text { Total gain } \\
\text { per cwt.. }\end{array}$ & & $\begin{array}{r}163 \\
50.90\end{array}$ & $\begin{array}{r}164 \\
68.306\end{array}$ & $\begin{array}{r}166 \\
31.30\end{array}$ & $\begin{array}{r}164 \\
9.60\end{array}$ & $\begin{array}{r}156 \\
69.00\end{array}$ & $\begin{array}{r}157 \\
6-4.305\end{array}$ & 137 & 123 & 117 & $\begin{array}{r}124 \\
43.50\end{array}$ \\
\hline $\begin{array}{c}\text { Ave'ge gain } \\
\text { per cwt... }\end{array}$ & $1 \ldots \ldots \ldots \ldots$ & & & 63.90 & & & & & 52.20 & & \\
\hline
\end{tabular}


The remarkable uniformity of this lot is strikingly shown by the "total gain" in both sets, in table No. 1 , but particularly in the ease of the five pens in the barn, the difference between the greatest and least gain being only ten pounds.

In Tible No. 2 the general results of this experiment. (1880-1) are given.

TABLE NO. 2.

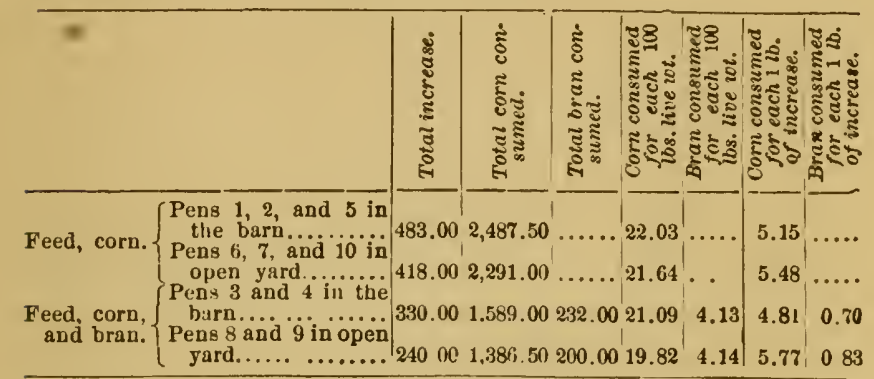

A good general view of the results of this experiment may be had by taking as the standard of comparison the cost of $100 \mathrm{lbs}$. of increase in the two lots of both series, receiving different feed :

$100 \mathrm{lbs}$ of increase, in pens 1,2 , and $5 \ldots \ldots \ldots \ldots . . . . .60$ cost, $515.02 \mathrm{lbs}$. of corn, $100 \mathrm{lbs}$, of increase, in pens 6,7 , and $10 . \ldots \ldots \ldots \ldots$ cost, $548.08 \mathrm{lbs}$, of corn.

This gires to the three outside pens, in which corn was exclusively fed, a loss of $33.06 \mathrm{lbs}$. of corn per ewt. of increase, as compared with pens in which the same feed was use $\mathrm{in}$ the barn, and in the $418 \mathrm{lbs}$. of increase in pens 6,7 , and 10 , a loss of 138.27 lbs. of corn, or about six (i) per cent. of the 2,291 lbs. of corm fed in these pens.

$100 \mathrm{lbs}$. of increase, in pens 3 and 4, cost $481.51 \mathrm{lbs}$ of corn and $70.30 \mathrm{lbs}$. of bran. $100 \mathrm{lbs}$. of increase, in pens 8 and 9, cust $577.70 \mathrm{lbs}$. of corn and $83.33 \mathrm{lbs}$. of bran.

This gives to the two outside pens in which eorn and bran were fed, a loss of $96.19 \mathrm{lbs}$. of corn and 13.03 of 
bran per ewt. of inerease; and in the total of $240 \mathrm{lbs}$. of increase mate in these pens, a loss of $230.8 .5 \mathrm{lbs}$. of coln and $31.22 \mathrm{lbs}$ of brim, amounting to about 16 per cent. of all the corn and 15 per cent. of all the bran fed in pens 8 and 9 in the open yart.

It will be observed that the pigs fed ontside, besides giving much smaller returns for the feed consumed, in all cases gave less "total gain," and much less "gain per ewt.," as shown in table No. 1, and consumed much less feed thim those fed in the barn.

The total loss from feeding in the open yards was quite marked throughout, and the variation in individual cases was considerable. It was noticeable that the quietest animals, the best feeders of those fed ontside, cndured the severe weather the best, and gave the largest returns for food consumet. 'These, during the severe weather which prevailed during the sixth, ninth, and tenth weeks, passed much of the time in a condition closely resembling hibernation; they came to their feed during severe weather with great apparent reluctance, and rarely oftener than once each day. during the remainder of the time lying very still, the vital functions manifestly moving at the slowest pace.

'T'he importance of a ration of bran or other coarse feed in connection with corn, for fattening pigs, is frequently urged by writers, on theoretical grounds. It was chietly to test this question that bran was used with corn in the proportion before detailed, in two of the pens of each of the two series. 'The value of the bram fed in this experi ment may be shown in a brief summary and comparison of the results obtained. In pens $1,2,5,6,7$, and 10 , in which corn wats exelusively feel, $901 \% \frac{1}{2}$ los. of increase cost 4,7\%8.5 lbs. of corn, and in pens $3,4,8$, and 9, in which corn ind bran were ferl, 5:0 lbs. of increase cost 2,975 lbs. of eorn and $43: 2$ lbs. of bran. 'That is, 
100 the. of inerease, In pens $1,2,5,6,7$, and 10. cost $530.3511 \mathrm{~b} 8$, of corn.

$190 \mathrm{lbs}$. of Increase, In pens $3,4,8$, and $9 . . . .$. cost $521.93 \mathrm{lbs}$. of corn and 75.78 Ibe. of bran.

Or 8.42 llos. of corn had, in this experiment, a feeding value equal to that of $75.78 \mathrm{lbs}$. of bran-a faet which scems to show that corn alone can be more profitably used for fattening hogs than a mixed feed consisting of corn and bran.

In table No. 3 is given the weight of each pig at the beginning of the experiment and at the elose of each week, the total gain, the total gain per ewt. of each pig, of the two sets in the experiment of $1882-3$.

TABLE NO. 3.

\begin{tabular}{|c|c|c|c|c|c|c|c|c|c|c|c|}
\hline \multirow[b]{2}{*}{ Date. } & \multirow{2}{*}{$\begin{array}{l}\text { Week of } \\
\text { Experi. } \\
\text { ment. }\end{array}$} & \multicolumn{5}{|c|}{$\begin{array}{l}\text { Pigs kept in warm pens } \\
\text { in the barn. }\end{array}$} & \multicolumn{5}{|c|}{$\begin{array}{l}\text { Pigs kept in open pens } \\
\text { in the yords. }\end{array}$} \\
\hline & & ?ִ & $\begin{array}{l}0 \\
0 \\
0 \\
0\end{array}$ & $\begin{array}{l}0 \\
0 \\
0 \\
0 \\
0\end{array}$ & $\begin{array}{l}\text { Td } \\
8 \\
8 \\
0\end{array}$ & $\begin{array}{l}T \\
0 \\
0 \\
0\end{array}$ & $\begin{array}{l}0 \\
0 \\
0 \\
0\end{array}$ & $\begin{array}{l}-1 \\
0 \\
0 \\
-1\end{array}$ & $\begin{array}{l}7 \\
0 \\
0 \\
0 \\
0\end{array}$ & $\begin{array}{l}-7 \\
0 \\
9 \\
0\end{array}$ & 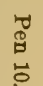 \\
\hline Nov. 27, ' 82 & $\begin{array}{l}\text { Begin'ing } \\
\text { of Exper't }\end{array}$ & 252 & 211 & 223 & 214 & 214 & 200 & 227 & 196 & 237 & 201 \\
\hline Dec. $4,{ }^{\prime} 82$ & Firs & $2(6)$ & $2 \cdot 2$ & 235 & 228 & 228 & 218 & 251 & 216 & 257 & 209 \\
\hline Dec, 11, '8: & Sie & $2 \% 5$ & 211 & 257 & 25,3 & 251 & 234 & 270 & 6 & 271 & 232 \\
\hline Dec. 18,82 & Thi & 293 & 253 & 268 & 262 & 258 & 244 & 278 & 249 & $28 \mathrm{~s}$ & 246 \\
\hline Dec. 25 , ' 82 & For & 309 & $2 \pi 1$ & 28.5 & $2 \div 5$ & 295 & 253 & 289 & 241 & 299 & 242 \\
\hline Jan. 1, ' 83 & Fif & 315 & 279 & 291 & 285 & 277 & 263 & 299 & $2: 9$ & 315 & $26 \mathrm{l}$ \\
\hline Jan. 8,83 & $\mathrm{Si}$ & 321 & 282 & 305 & 290 & 287 & 262 & 295 & $\because 69$ & 321 & 266 \\
\hline Jun. 15,83 & h.. & 313 & 301 & 319 & 311 & 296 & $2: 8$ & 319 & 276 & 338 & 270 \\
\hline Jun, 22,83 & $\mathrm{Ei}$ & 316 & $30 \mathrm{R}$ & 330 & 322 & 301 & 283 & $32: 3$ & $27 \cdot 2$ & 344 & 275 \\
\hline Jan. 29. 83 & $\mathrm{Nin}$ & 356 & 317 & 337 & 3.34 & 316 & 283 & 331 & 289 & 360 & 286 \\
\hline Feb, 5, 83 & Ter & 373 & 330 & 347 & 316 & 322 & 288 & 337 & 283 & 363 & $28 \%$ \\
\hline $\begin{array}{l}\text { Total gain. } \\
\text { Total gain }\end{array}$ & 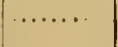 & & & 121 & 132 & 108 & 88 & 110 & 87 & 126 & 78 \\
\hline per cwt.. & $\ldots \ldots$ & 18.00 & 4 & 5.6 & 148 & 0.40 & 440 & 8. & 41. & 3.1 & .20 \\
\hline $\begin{array}{l}\text { Ave'ge gain } \\
\text { per cwt.. }\end{array}$ & $1 \ldots . .$. & & & 54.20 & & & & & 45.90 & & \\
\hline
\end{tabular}

Table No. 4 shows for each week of the experiment, the average temperature, total feed, the feed for each 100 lbs. of live weight of animal, the total gain, and the number of pounds of feed required for one pound of gain in the two phases of the experiment. 
TABLE NO. 4.

\begin{tabular}{|c|c|c|c|c|c|c|c|c|}
\hline & & & & $\mid \begin{array}{l}\text { lowruge } \\
\text { Ileckly } \\
\text { Temper- } \\
\text { ulure, } \\
\text { Fishr. }\end{array}$ & $\begin{array}{l}\text { Tolal } \\
\text { Feid, } \\
\text { lbs. }\end{array}$ & $\begin{array}{l}\text { Feed for } \\
100 \text { los. } \\
\text { of live } \\
\text { it. of } \\
\text { snimet. }\end{array}$ & $\begin{array}{l}\text { Tolal } \\
\text { Grin, } \\
\text { lbs. }\end{array}$ & $\begin{array}{l}\text { Lbs. of } \\
\text { Ficil jon } \\
\text { l lb. of } \\
\text { Cain. }\end{array}$ \\
\hline $\begin{array}{l}\text { thirs kept } \\
\text { in warm } \\
\text { pens in } \\
\text { tho bant. }\end{array}$ & 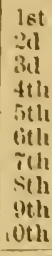 & $\begin{array}{c}\text { Weel } \\
.6 \\
4 \\
4 \\
4 \\
4 \\
4 \\
11 \\
\end{array}$ & $\begin{array}{l}\ldots \\
\cdots \\
\cdots \\
\cdots \\
\cdots \\
\cdots \\
\cdots \\
\cdots \\
\cdots\end{array}$ & $\begin{array}{l}35^{\circ} \\
3.3^{\circ} \\
36^{\circ} \\
4: 2^{\circ} \\
322^{\circ} \\
21^{\circ} \\
29^{\circ} \\
190^{\circ} \\
27^{\circ} \\
20^{\circ}\end{array}$ & 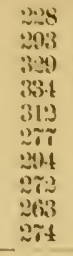 & $\begin{array}{l}19.8 \\
234.2 \\
24.5 \\
24.2 \\
21 . \overline{5} \\
15.5 \\
18.9 \\
11.1 \\
16.1 \\
16.5\end{array}$ & $\begin{array}{l}\text { 6i } \\
68 \\
51 \\
51 \\
312 \\
41 \\
52 \\
317 \\
513 \\
58\end{array}$ & $\begin{array}{l}3.30 \\
2.95 \\
6.10 \\
4.12 \\
3.76 \\
\text { (i. } 80 \\
3.55 \\
7.32 \\
4.94 \\
4.72\end{array}$ \\
\hline $\begin{array}{l}\text { ligs kept } \\
\text { in pens in } \\
\text { (1pen yard. }\end{array}$ & $\begin{array}{l}1 \text { st } \\
\text { 3d } \\
3 \mathrm{tl} \\
4 \mathrm{th} \\
5 \mathrm{th} \\
\text { tith } \\
\text { ith } \\
\text { sth } \\
\text { oth } \\
10 \mathrm{th}\end{array}$ & $\begin{array}{c}\text { Weel } \\
\text { "1 } \\
" 1 \\
1 " \\
" 1 \\
" 1 \\
" 1 \\
4\end{array}$ & $\begin{array}{l}\ldots . . \\
\ldots . \\
\ldots . \\
\ldots . \\
\ldots . \\
\ldots . \\
\ldots . \\
\ldots . \\
\ldots .\end{array}$ & $\begin{array}{l}31^{\circ} \\
2020 \\
21^{\circ} \\
210^{\circ} \\
15^{\circ} \\
15^{\circ} \\
5^{\circ} \\
15^{\circ} \\
12^{\circ} \\
15^{\circ} \\
20^{\circ} \\
20\end{array}$ & 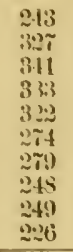 & $\begin{array}{l}21.9 \\
26.9 \\
26.0 \\
25.3 \\
11.8 \\
190 \\
19.2 \\
16.0 \\
16.3 \\
14.4\end{array}$ & $\begin{array}{l}8 \% .0 \\
8 \% .0 \\
62.0 \\
19.0 \\
73.0 \\
16.0 \\
18.0 \\
16.0 \\
55.0 \\
1.0\end{array}$ & $\begin{array}{r}2.80 \\
3.98 \\
5.50 \\
1 \% .50 \\
4.41 \\
1 \% .50 \\
4.11 \\
15.40 \\
4.61 \\
200.00 \\
\end{array}$ \\
\hline
\end{tabular}

From the table No. $t$ it will be secu that :

In peng $1,2,3,4$, and 5 , lu the harn, ?., sis ib-, of corn gave 60.1 lbs, of pork, and " . 6, 7, 8, ?, aud 10, outside 2.814 " " " 479 " " Or.

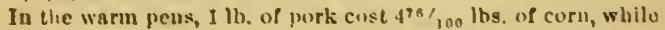
Iu the untside " 1 " " $" 593 / 100$ " "

Aguln-In pens 1, 2, 3, 4, and 5, In the barn, one lushel of corn produced $11^{\text {in } / 100}$ lbs. of pork.

In numbers $t, 7,8,9$, and 10 , oulside, the same quallty of corn produced $93 / 100$ lbs. of purk.

Or, in other words: of erery bushel of corn fed in the five open pens, an amount sufficient to make $2^{39} / 100 \mathrm{lbs}$. of pork was used up in keeping the minal warm.

The effect of very cold weather upon fattening pigs is still more strikingly shown by comparing the results obtained in the two sets-barn and ontside-during the four weeks of lowest temperature, namely, the sixth, eighth, ninth, and tenth weeks of the experiment, as follows:

In the wnrm harn, 1.0\$t los. of corn gave 190 pounds of pork.

In the open pens outside, $99 ;$ libs. of corn gave $8 S$ lbs. of pork. 
Or, In the warm harn, during the asverest weather, 1 lh. of pork cost 6.71 lhs. of corn.

While vistide, during the severest wealher, $1 \mathrm{lb}$. of pork cost $11.32 \mathrm{lbs}$, of corn.

It is found that during the period of highest tempera. ture, when mild winter weather revailed (the average temperature in the barn wis thirty-seven degrees, ontside twenty-six degrees), the pigs in the barn marle a much larger increase in weight (thirty-one pounds) than those in open yards, upon less corn (sixty-one pounds), giving a pound of increase for about four-fifths of the corn required by the pigs in the exposed pens. In the period of greatest cold this variation is much more marked, as shown above, except in the total corn consumed, the pigs in the barn consuming eighty-nine and a half pounds more of corn than those kept ontside. The small amount of feed consumed outside, during this period, is safely attributable to the severe weather that prevailed during the time referred to.

The principal results of this experiment may be shown in a few brief comprehensive statements :-

(1.) In the warm barn, $2,87 \% 1 \%$ pounds of corn gave 604 pounds increase in the weight of the pigs, while in the open yards 2,844 pounds of corn gave 479 pounds of increase.

Or, in the exposed pens, the cost of one pound of increase was almost twenty-five per cent greater than the cost of one pound of increase in the warm barn.

(2.) Besides giving less of "total gain" and "gain per ewt." in every pen, during every week of the experiment, the pigs fed outside gave much smaller returns for f(ed consumed, but this was especially marked during the weeks of lowest temperature.

'I'hus, during the three weeks of greatest cold, the pigs in open yards requirer $17.50,15.46$, and 226 pounds of corn for each pound of increase, while in the warm barn, during the same three weeks, $6.80,7.32$, and 4.72 
pounds of eorn respectively were expended for one pound of increase.

(3.) In this, as in the experiment made two years ago. I have observed that the quietest pigs, the "best feeders," sutfered laast from cold, ate the best, and gare the largest returns for feed consumed.

(4.) 'The fluetuations in the weekly gain were very much greater in the pens in the epen yards: but, as shown in 'Table No. IV., whenever little gain or a positire loss was sustained-as in the pens 8 and 10 , Anring the fourth week, and pens 6 and $\%$, during the sixth week-an enormous gain was made during the week following, even though the temperature continned low, as though the animals were making a determined etrort to recover lost ground.

(i.) The fluctuations in the total feed consumed, or in the amount of feed consumed for each 100 pounds of live weight of animal, were not great in the different pens, or in different weeks of each pen, although these thetuations were greatest in the "outside" pens, the smallest amount of feed being consumed during the coldest weather. It is worthy of remark, howerer, that in the weels following, those showing the least gain in flesh or the greatest loss, when the largest inerease was made, as stated above, the increase in the amomnt of feod wis inconsiderable: in some cases nothing. 'Thus in pens 6 and $\%$, in the sixth week, and in pen $\delta$ in fourth and eighth wecks. the pigs lost $1,4,8$ and 4 pounds respectively. while in same order consuming $55^{\prime} / 2.48$, 61 and $43 \%$, pounds of corn. Muring tho week following. when the same pigs gained in weight, $16,24,18$, and $1 \%$ pounds, the enormous gain was mato at a cost of $551 / 2,5 \%, 60$ and $46 \%$ pomds, respectively, of roln.

Sulely these facts ean lead to but one conclusion, that it will pay to give pigs walm guaters during the feoding 
period. Maty we not reasonahly infer from these same ficts, that all clisses of domesticater animals, for whatever purnoses they are kept, will give the largest profits when well housed and made comfortable?

\section{CIIAP'TER XX.}

\section{FEEDING FOR FAT AND IUEAN.}

It can searecly be denied that during the period of say thirty years in which general attention bas been paid to improving and largely rearing improved breeds of swine, the tendency hats constantly been towards producing animals that yiched a maximum quantity of fat or lard with only a minimum of lean meat or muscle. 'This is asily traceable to the fact that the principal food of the swine in the regions where they are most rased is Inclian corn, which is a fat-former mequaled hy any other grain grown or need on American farms. Among other resnlts of feeding almost exclusively generation after generation of animals a food so ill balanced or imperfectly alapted for a general naintenance ration, are an impaired vitality, a weakened bony structure, decreased fecundity, and in the matured carrass a ratio of fit to lean meat mueh greater than the arerage consumer fin??s profitalule to buy or palatable to eat. Among the subjects that the better class of hog-raisers are now coming to consider as of importance are the treatment and foorls, or ecnubinations of foods, hest adlapted to economically produce pork with such an increased pereentage of lean, or judicions admixture of lean with fat, as shall he most healthful, most palatable, and most eagerly sought by thoce upon whom their market depends, aur hest for their families. Helping to the solution of suc! problems has already 
beeome recognized as a part of the legitimate work at the different State Experiment Stations and Agrieultural Colleges, and a valuable beginning in that particular line has been made by Prof. J. IV. Simborn, at the Missouri Agricultural College. and by Prot. II. A. Henry, director of the Agricultural Expriment st:tion at the L'niversity of Wisconsin. The experiments of eneh produced a great similarity in results aml are very interesting. In making a condensed report of his effort in that direetion for this rolume, for which he will have the thanks of the reader as well as the anthor, Prof. Henry says :

"Once knowing that foods of different compositions do affect the frame and flesh of animals ditferently, and how and why, we are in position to go ahead and huld up a better system of swine husbandry than we now hare. Knowing eorn to be a miversal hog food and often nsed almost exelnsively by many of our farmers, and further knowing that chemistry shows that corn is excessirely rich in the earbohydrates or heat and fat-formers, while it is low or poor in protein and ash elements which go to make up bone and muscle, we thought to feed it exclnsirely to one lot of hogs that we might see the effects it produces. To another lot it was thonght best to feed a rition excessively rich in protein, which makes it the opposite of the first ration. To this end we made up a ration of shorts, sweet skim milk and a little dried blood. Dried blood is not often used as a food, but is wonderfully rich as may be supposed in the same elements as dried beef. Dried blood, skim milk and shorts are each comparatively rich in protein. so it will be seen our feed for the second lot was rich in muscle-making food, and if there is anything in what ehemists tell ns about foods, our pigs, having such widely different rations, should show it in their bodies, if the character of the food makes any difference. 
"Out of a litter of eight pigs, six were selected, even in size and form, for the trial, when they were 100 days old. Up to the heginning the pigs were all fed alike, from the siture trough, a mixture consisting of shorts, corn meal, skim milk and buttermilk. 'The pigs were crows-bred Jursey Reds and Poland-Chinas. At the beginning of the trial the six were divided into two lots of three each, and to loot $A$ was fed a ration consisting of one part of dried blood, six parts of shorts, and fourteen parts of swect skin milk by weight. To Lot B was fed all the fine ground corn meal they could properly consume. Water was freely provided for each lot, and each had the run of a small yard back of the feerling pen in which excrcise could he taken; all went on with remarkalile uniformity from first to last, with no accident of anv kind during the whole period of 136 days. The following shows in a condensed form the amount of food cunenmed by the two lots during the trial of 136 days :

IOT A, YEI YOR LEAN.

Amount of sweet skim milk consumed ..............3,3012 1hs.

A mount of shorts consurnerl ..................... $1,4151 / \mathrm{r}$ ths.

A mount of dried blrorl consumed ................ 235 $5 / \mathrm{l}$ lbs.

IOT 13, YEIS YOR FAT.

Amount of corn meal consumed.................... $1,890 \mathrm{lbs}$.

"T'he digestikle matter in the food fed to the two lots was as follows:

Protein. Carbohydrates.

Total digestible matter fed to Iot $\mathrm{A}$..... . $428 \mathrm{lh}$..... $8.33 \mathrm{lbs}$.

Total digestible matter ferl to Lot B.....153 lbB.... .1,193 lhs.

"It will be seen that each lot received about the same number of pounds of actual food, but that the proportion of the protein to the carbohydrates varied greatly. Protein goes to make muscle, though it may he used for heat and fat in the borly. 'The carbohydrates (starch, sugar, etc.) cannot make muscle in the body of an animal, though they may suve it from waste and decay, but. are used for maintaining the hodily beat and for 
making fat. Onr corn-fed hogs then were fed a rery fattening foot, while the other lot were giren a large amount of muscle- (or lean meat) making material. Ilere we liave our feeds so widely different in character that the elleet should be very evident in the earcasses of

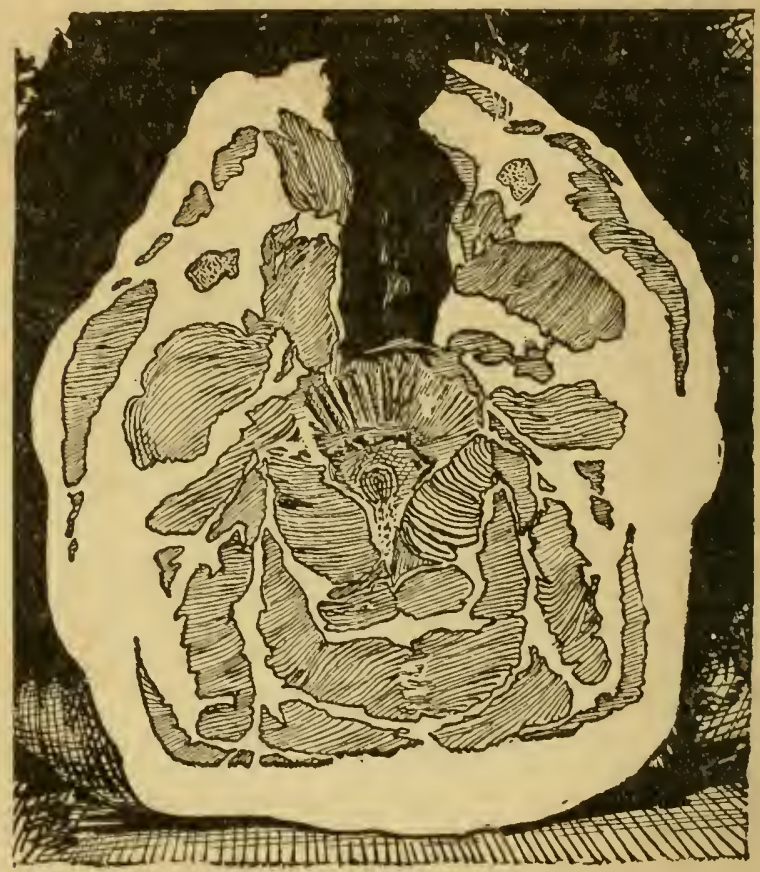

Fig. 12.-FED For leAN. Iot A, No. 1, Protein fed.

the hogs, if the charaeter of the food affects the composition of the body.

"'The hogs were slanghtered Nor. 8, 18s6, a slilled hutcher assisting, every operation being conducted with great care and precision. After taking the lire weight of each animal, it was killed by slow bleeding, and the blool eaught and weighed. 'The viseera were taken out 
ind each organ weighed and the dressed hogs hung up to cool and stiffen.

"Upon being taken to the block each dressed hog was "laid on his back, and first the head was severed, next the body was eut square across between the fifth and sixth

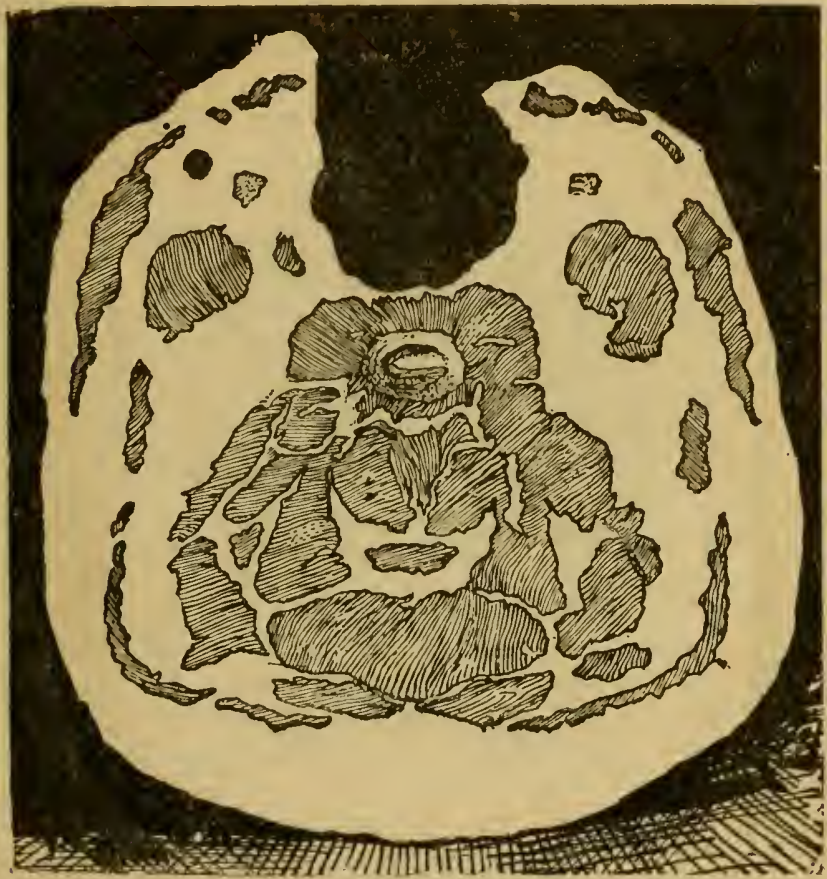

Fig. 13.-FED FOR FAT. Lot B, No. 1, Carbohydrate fed.

Figs, 12 and 13 show in cross section the proportional size of the muscles (lean meat) in the necks of hogs of each lot.

ribs, and again at the loin or small of the back. A painter was employed to sketch the appearanee and disposition of the fat and lean meat as exposed by the cuts. learing the painter was not exact enough, a photographer was employed for the same purpose, and we were 
thus enabled to preserve for future reference and study that which would have otherwise soon been lost.

"The illustrations which are herewith presented show the proportion and disposition of the fat and lean in some of the cuts. We present six, three of each lot.

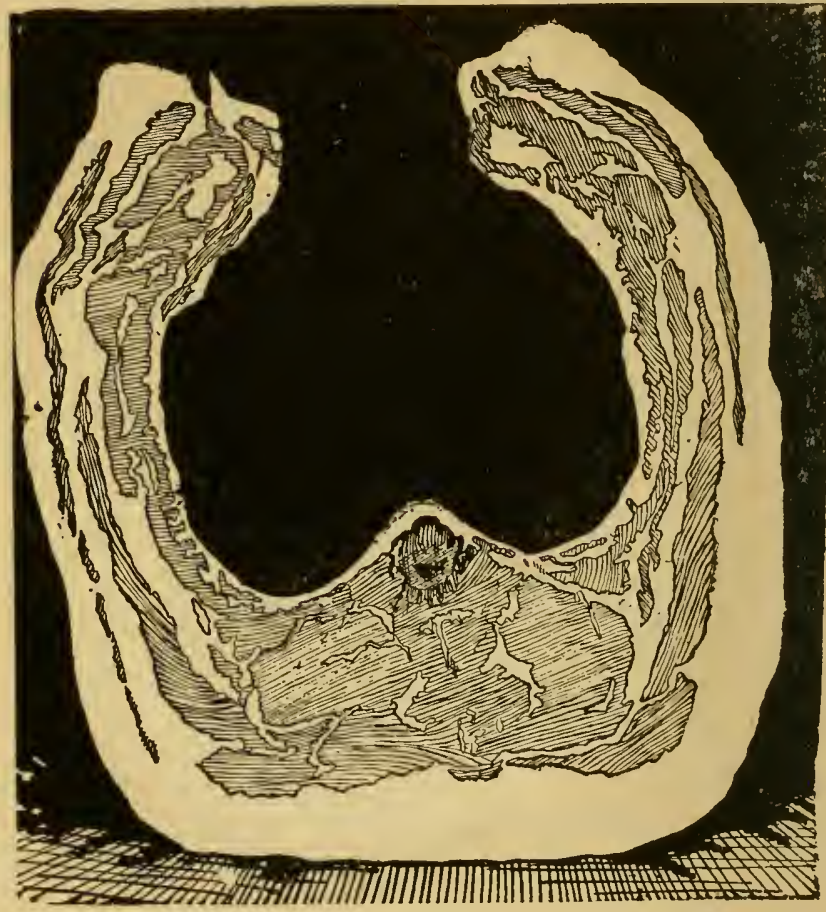

Fig. 14.-Fed for lean. Lot A, No. 2, Protein fed.

The first two show what we found on severing the heads of the first hog of each lot. The second two show in the same way the cuts made between the fifth and sixth ribs of the hogs numbered "two" in each lot; while the last two engravings show the loin cut of the hogs numbered "three" of each lot. In each of the engravings 
the dark shaded parts represent.lean meat or muscle, while the fat is shown by the white parts. As in cutting across the body at the three places named we cut square across most of the muscles, the reader can see the relative size of each muscle in cross section in two hogs of

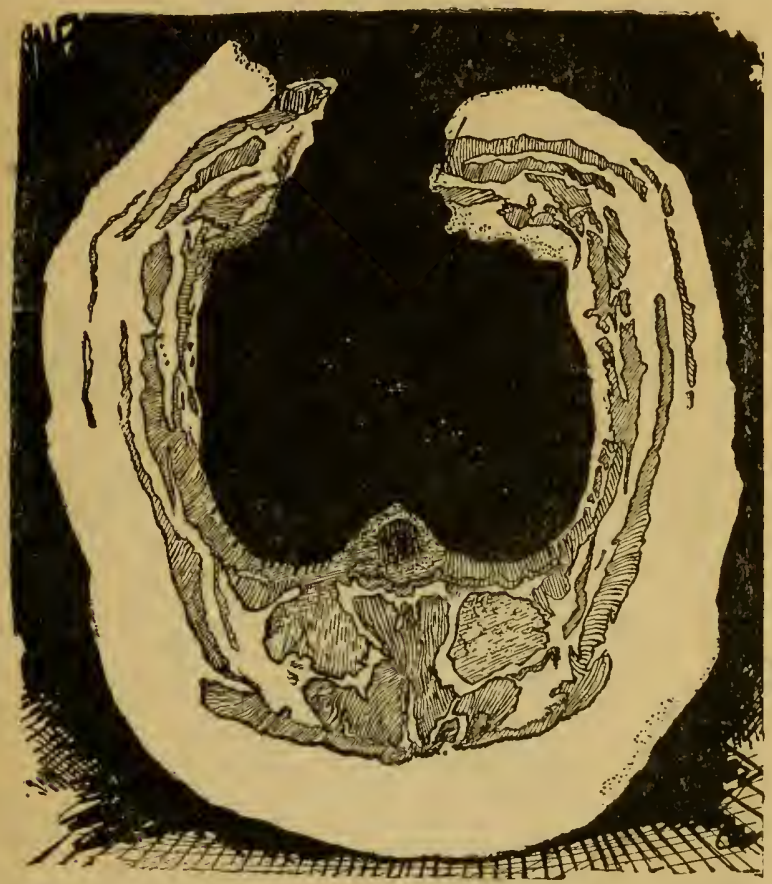

Fig. 15. -FED FOR FAT. Lot B, No. 2, Carbohydrate fed.

Figs. 14 and 15 show in cross section the proportional size of the muscles (lean meat) over the heart of hoys of each lot.

each lot. The illustrations are made from the dressed hogs lying on their backs.

"The reader is asked to give these illustrations more than a passing glance-to study each. It will be seen in each case the muscles (red or lean meat) of the proteia 
fed hogs are larger than the same muscles of those fed the ration rich in carbohydrates. Even the muscles of

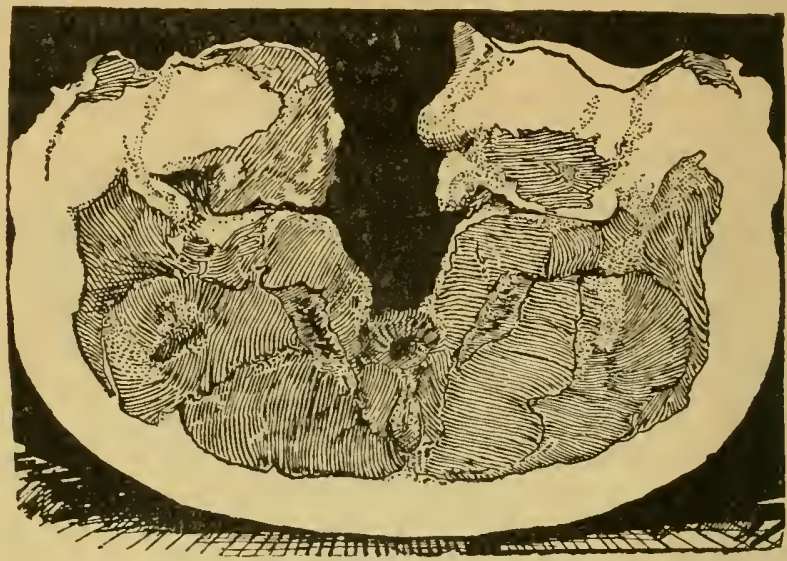

Fig. 16.-Fed for Lean. Lot $A$, No. 3, Protein fed.

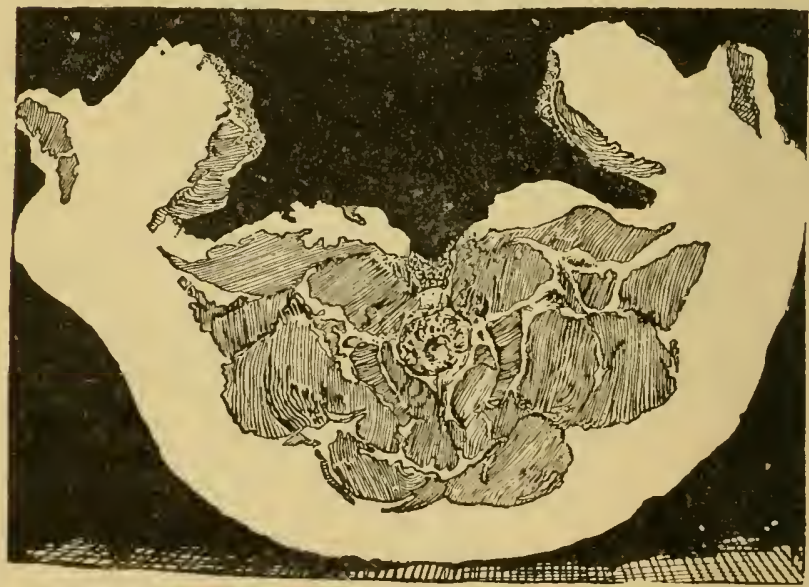

Fig. 17.-Fed For FAT. Lot B, No. 3, Carbohydrate fed.

Figs. 16 and 17 show in cross section the proportional size of the muscles (leun nizeat) of the hogs of each lot cut through the small of the back.

the neck are stronger, as shown in the first two cuts. On the back over the heart, the muscles of Lot $A$ show 
far less fat between them than of Lot $B$. The most reo markable difference, though, is in the small of the back, where it will be noted that Lot $\mathrm{A}$ has abont twice as much muscle as Lot $B$.

"The riscera of each lot was carefully dissected ont and weighed and some most remarkable differences between the two lots were found. The hair was saved and weighed. Each hog was carefully skinned and the skins weighed. The large muscle of the back, also the tenderloin muscles, were dissected and weighed. The bones were freed from tendons and flesh by boiling and the thigh bones were broken on a testing machine, to determine the strength of each. Each bone was laid on two iron edges abont a quarter of an inch thick, set four inches apart; a similar iron edge was bronght down from above just midway between the two edges below. T'his plate was crowded down by a lever mitil the bone broke. In this way we broke five thigh bones of Lot A, and the same of Lot B. We found that the aggregate pressure required to break five thigh bones with the protein fed hogs was 4,550 pounds, or an average of over 909 pounds per each bone; against 2,855 pounds, or $5 \% 1$ poun ls per each bone, with the corn fed hogs. Here was a weakening of the bones of over 300 pounds each in 136 dars.

\section{"IMPORTANT CONTRASTS IN IVEIGHTS.}

"The following table gives the most important facts in the case, the weights being of three hogs in each lot.

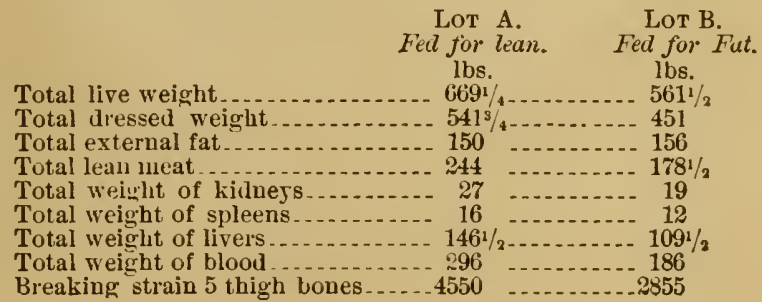


"But figures placed in this way are largely lost to the general reader, so I will take the liberty of placing them in a different form :

1. The live weight of Lot $\mathbf{A}$ (fed for lean) is 19 per cent greater than Lot $\mathrm{B}$, fed for fat.

2. The dressed weight of Lot A is $\approx 1$ per cent greater than Lot B.

These differences should be borne in mind in considering what follows.

3 . The kidneys of Lot A weighed 4: per cent more than those of Lot B.

4. The spleens of Lot A weighed 33 per cent more than those of Jot B.

5. The livers of Lot $A$ weirhed 32 per cent more than those of Lot $B$.

6. The blood (caught on lilling) of Lot A weighed 59 per cent urore than that of Lot B.

7. The hair on Lot A weighed 36 per cent more than that of Lot B.

8. The skin of Lot A weighed 36 per cent more than that of Lot B.

9. The larire inuscl's of the back (llio spinulis) of Lut A weighed 64 per cent more than those of Lot B.

10. The two tenderinin muscles (Fsoas magnzs) of Lot A weighed :\& per cent more than those of lot $B$.

11. Thirty-eight per cent of all the meat that conld be cut from the eareasses of Lot $A$ was fat, while the fat of lot $B$ was 46 per cent of all that could be sej)arated.

$1: 2$. The trones of Lot A were 23 per eent heavier than those of Lot B.

$1 \mathrm{i}$. The thigh bones of Lot A were tis per cent stronger with the testing machine than those of Lot B.

“In testing the strength of the bones another remarkable exhibition of the difference in the lots was obtained. By the table it will be seen that the number of ponnds pressnre required to break the thigh bones of the hog was as follows :

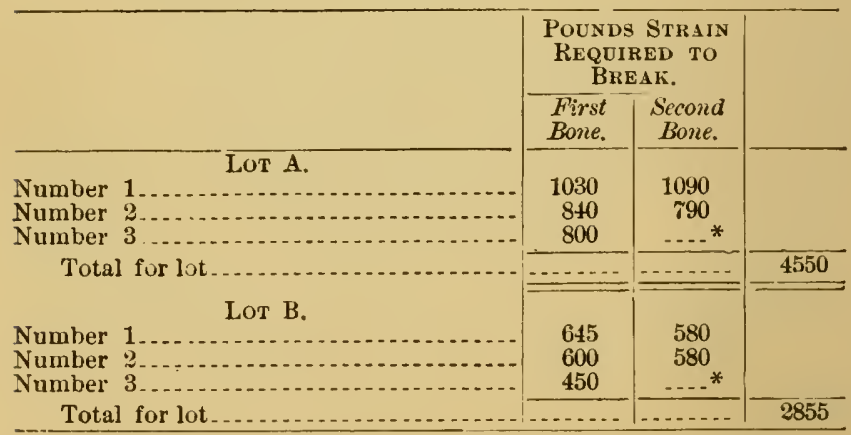

* A ham from a hog of each lot was cut across to examine the meat, and in this way one thigh bone was spoiled for this test. 
"We observe an excess in weight of most of the impor. tant organs of the interior cavity in the hogs fed for lean over those fed for fat. These differences cannot be accidental, as they are the average of the lots in each case, and the work was too carefully done to have errors sufficient to cover such differences. It will be noted that the liver, kidneys and spleen are all considerably larger with Lot A than with Lot B. A most strik. ing difference is seen in the blood obtained upor. killing the hogs. From the three hogrs fer for lein we got 18 pounds, 8 onnces of bloou. whice from the three fed for fat only 11 pounds, 10 orinces. While the blood thus obtained is not by any means all that is in the body of the log, it is remirkable that we should get so much more from one lot than from the other.

"Before making any deductions we wish to make plain, if possible, that which seems a most important consideration, and one that must be clearly understood before we can use these experiments as we should. All through this discussion, we have carried the impression that we could put lean meat or fat on the hog at will ; but car. we? Is it not true that in every animal there is a certain limitation to muscular development beyond which it cannot go? The blacksmith or the baseball player develops a large amount of muscle, but the limit is not very high, after all, with them, and probably a mau weighing 175 pounds cannot add, either by what he eats or the exercise he takes, over a very few pounds of real meat or muscle to his body; indeed when men "go into training" they reduce their weight as a rule instead of increasing it, getting rid of fat and water in the body. On the other hand, when men have a tendency to laying on fat, the limit they may reach may double their normal weight. We may say, then, that the possible muscular development of an animal has a narrow limit 
comparitively, while the possible fatty derelopment has it much willer range.

"We should hold, it would seem, that our hogs which show the best museular devolopment are only normally developed, or at least have not departed far from the normal, and that whatever we find in them is a condition to be held ats a standard, while our hogs which have grown fat and show at variation from the lean logs are abnormil.

"Having assumed the above as eorrect we can make a much elearer statement of the dednetions which may be drawn from the experiments. The experiments show that when we feed to our hogs a ration rich in carboliydrates but lacking in protein, like corn meal, we will find :

"1. That there is au excessive development of fat not only on the outside of the museles and beneath the skin but also among the museles. 2. That the muscles of the borly fail to develop to their normal size, especially some of the most important ones, as those along the back. 3. That an abnormally small amount of hair and a thin skin results. 4. 'Tluat while the brain, heart and lungs do not seem to change in weight, the spleen, liver an. l kidneys are unusmally small. 5. 'The amount of blool in the body is greatly redued from the normal. 6. 'I'lie strength of the bones may be reduced one-half.

"We may conclude that a system of feeding which robs the hog of half its blood and half the natural strength of its bones, and produces other violent changes, is a most unnatural one, and must, if persisted in, end in giving us a race of animals unsatisfactory to all concerned. From parents thus weakened must come descendants that will fall easy vietims to disease and disaster. Knowing the facts as here set forth, can we any longer wonder that our logs are weak in constitution and easily break down when attacked by disease? Nor is 
this all; the meat from such animals can hardly be of flavor and composition satisfactory to the consumer.

"If even a part of what has been set forth is correct, is it not high time we turned our energies toward better methods? 'To do this calls for higher thought and better care, but I fully believe no extra outlay of moncy; rather, I believe, we can feed hogs more profit. ahly by rational metlods than by the usscientific and shiness ways now only too common. First of all, we must sec to it that breeding sows are fed a proper ration in which protein compounds form a liberal share. The young pigs must likewise have a goodly allowance of protein, while the mature hogs, when fattening, can be fed a large proportion of carbohydrates, especially if wo wish to make a large proportion of lard. The food articles at our conmand which are rich in protein are skim milk, buttermilk, slıorts, bran, peas, green clover, and the like. No farmer can afford to manage his farm with a minimum of these muscle-making foods; they should be supplied abundantly and at a reasonable cost if we will only sturly to do so.

"Shall we raise less corn, then? Not at all. The corn crop is the best of all we raise, and let the word lie "more," rather than less. We need it all, lut we must not forget that protein is somewhat lacking in the corm. We may compare our corn to the bricks which go into a building, and the protein food to the mortar which cements the bricks together. He who would lay up hricks without mortar builds foolishly, and his louse will tumble. Should he find out his mistake, such a man should not from that date neglect the bricks and turn his whole attention to the mortar. Plenty of good strong mortar and an abundance of bricks are what he neerls. We do not want less corn, but we want more elorer, more shorts, more bran, more peas, more skim milk, and more clover to bring the highest results. 
Withont attempting to give any exact rules for guidance, the following statements may not he out of place: During gestation, breeding sows should lave only a small allowance of corn, the feed being mainly that which will go to give her young good sound bodies. Such feed would be slıorts (middlings or shipl-stuff), bran, skim milk, buttermilk and clover. When suckling her young, of conrse milk is one of the best articles at our command. When weaned, the pigs may get say two parts of milk by weight, one part of shorts and one part of corn meal. A run on good clover would go far to make a good frame. When nearing maturity the ration can be changed more and more to the carbonaceous, and for the last two months, when fattening, the feed can be largely corn, if one desires fat pork, but if lean juicy meat is desired the muscle-making foods must be continued."

In writing of some further experiments he made with other lots of hogs, to see if the results confirmed those previonsly made, Prof. Henry says that "in general they did." Toone of these lots eorn meal was fed ; to another skimmed milk and corn meal, and shorts and corn meal to a third. His conclusions from what he has sen are that "skimmed milk and corn make the largest hog with the strongest bones; that corn alone makes the next largest hog with the weakest bones; that two-thirds s'iorts and one-third corn meal make the smallest hog with the most muscle, most blood, and bones very much stronger than the corn alone."

In the experiment by Prof. Sanhorn there was fed to one lot of pigs a ration of four parts of ship-stuff (shorts or middlings) to one part of elried blood, this forming a ration excessively rich in protein; to the other lot wis fed a ration of corn meal which, as before stated, is excessively rich in carbohydrates. Two hogs of each 
lot were killed and examined unon reaching maturity, with the results shown in the following table:

\begin{tabular}{|c|c|c|c|c|c|c|c|c|}
\hline & \multicolumn{4}{|c|}{ Lot I-Fed jor Lean. } & \multicolumn{4}{|c|}{ Lot II-Fed for Fat. } \\
\hline & No. & 1. & No. & 2. & No. & 1. & No. & 2. \\
\hline & Jbs. & oz. & 1 bs. & oz. & lbs. & oz. & lbs. & $\mathrm{OZ}$ \\
\hline Iire weight of pig..... & 138 & $6 \frac{1}{4}$ & 170 & $4 \frac{1}{6}$ & 139 & 15 & 170 & 14 \\
\hline Heart $\ldots \ldots \ldots \ldots$ & & $6 \frac{1}{8}$ & & $8 !$ & & 7 & & 10 \\
\hline Lungs & 1 & $9 \frac{2}{3}$ & 1. & $15 \frac{1}{4}$ & 1 & 156 & 1 & $133 \frac{4}{5}$ \\
\hline $\begin{array}{l}\text { Liver } \\
\text { Spleen } . \ldots\end{array}$ & 3 & $\begin{array}{l}3 \\
\sim\end{array}$ & 4 & $3 i$ & 2 & $\begin{array}{l}5 \frac{1}{2} \\
2 \frac{1}{6}\end{array}$ & 2 & 3 \\
\hline Kidneys & & $8 \frac{1}{3}$ & & $8 \frac{1}{8}$ & & $4 \frac{1}{6}$ & & $5 \frac{1}{6}$ \\
\hline Leaf. & 2 & 2 & 4 & 10 & 5 & $4 \frac{6}{6}$ & 7 & $13 \frac{1}{4}$ \\
\hline ............. & 6 & 4 & 5 & 14 & 5 & 4 & 7 & 8 \\
\hline Intestines. . & 12 & 10 & 11 & $12 \frac{1}{8}$ & 10 & 8 & 11 & \\
\hline Fat of intestines....... & 2 & 10 & 3 & $12 \frac{1}{8}$ & 4 & 5 & 4 & \\
\hline Brains & & 4t & & $4 \frac{1}{6}$ & & $3 !$ & & 44 \\
\hline Fat of body & 38 & 14 & 50 & 3 & 46 & 4 & 70 & It \\
\hline Leall and bone......... & 64 & & 79 & & 58 & 4 & 57 & 11 \\
\hline Hair $\ldots . . . . . . . .$. & & 11 & & 13 & & $9 \frac{1}{6}$ & & 11 \\
\hline Blood and loss in cooling & 4 & $15 \frac{1}{\frac{1}{8}}$ & 6 & 11 & 4 & $1 \frac{1}{4}$ & 6 & \\
\hline
\end{tabular}

\section{CHAPTER XXI.}

THE GRADUAL DISAPPEARANCE OF WHITE SWINE FROM AMERICAN FARMS.

Most of those who were familiar with hog-raising in the United States twenty years ago, are aware that white swine were much the most numerous, and that in many localities those of any other color were so rare as to be regarded almost as curiosities. Since that time, or perhaps more particularly since about $1865-6$, the black or black-spotted swine have grown rapidly in popular favor so much so, in niany sections, as to practically displace all others.

Our attention was incidentally called to this fact many times during the year 1881, and in November of that year mention of it was made in a prominent publication devoted to live stock, only to be vigorously combated as a mischievous and exaggerated statement. The vigor of 
these contradictions cansed us to make some effort to ascertain whether the position, as to the disappearanee of the white hogs, was or was not really well taken, our own personal observation having been made more especially in Kansas. As to the swine displayed at the two (virtually) State fairs there in 1381, we found that at the exhibition at Lawrence there were abont 300 specimens, but one of which was white : that one was a Chester boar shoat, brought hy some Illinois breeders, with their display of twenty-four black hogs, in hopes of finding some one in the State who would buy him. At the State fair licld at Topeka, the Secretary informed us that there were entered in the Berkslire rings, 36s; PolanelChina. 350; Essex, 23: Jerscy Red, 18; Chester White, 1 ; total number of entries, 760 .

From the Secretary of the Illinois Board of Agrieulture and his reports, we learned that at their State fair in $18 \%$, there were 843 entries of swine, and all but 181 of them were entries of Poland-Chinas, Berkshires, or Essex; in $18 \% 8$, he reported 684 entries, all Poland-Chinas, Berkshires or Essex, but 223; in 18\%9, he reported 516 entries, 74 of them Chesters, 66 Suffolks, and $3 \% 6$ Poland-Chinas, Berkshires, or Essex; in 1880, he reported 437 entries, of which 269 were Poland-Chinas, Berkshires, or Essex. Seeretary Fisher wrote, that in 1881 the entries were, Poland-Chinas, 11\%; Berkshires, 141; Essex, 5\%; total black, 315, against 112 entries of Chesters and Small Yorkshires. The Reports of the Indiana Board of Agriculture stated that at the State fair of $18 \% 9$ there were $29 \%$ entries of swine, of which 25 were large white breeds, 28 "Essex and Suffolk," and 4 "Red," against 240 Poland-Chinas and Berkshires; in 1880, there were 314 hogs entered, and 287 were of other than white breeds. Under date of December 8th, ult, the Secretary of the Ohio Board of Agriculture wrote: "Of the hogs exhibited at our fairs for two or three years past, 
about 70 per cent. were of the dark breeds; the white breeds seem to be rapidly on the decrease."

Prof. L. N. Bonham, of Ohio, a gentleman who knows much of the swine interests of his section, wrote us December \%th:

"In Southern Ohio, I think, white hogs are not so numerous as ten years ago. Occasionally, some farmer, with more enterprise than good management, conclurles his swine are not so good, do not make as wonderful growth as some hreeders claim in their advertisements of white or red hogs, and accordingly invests in a Chester White or Jersey Red boar. We have had a few such cases in this county, but they do no better than our Butler County Polaud-rhina swine, and the buyers do not continue in the use of thom. These new purchases only add to the number of mongrels, of off-color. They are not better feeders nor are they cbolera proof, as one breeder claims for his red hogs. So rare are white hogs here, that they are a curiosity."

Of the more recent State fairs in Iowa, Secretary John R. Shaffer wrote:

"The number of entries of dark breeds of hogs at our State Fair of 1880, was 226; of white breeds, 104. Fair of 1881, there were of the dark breeds, 253 ; white breeds, 110 . This would indicate about one-half; but our white hogs, I do not think, would exceed 20 per cent. Poland-Chinas and Berkshires are the predominant breeds, with the Polands in the lead."

As to the great fairs of the North-west, held at Minneapolis, Minn., we wrote to the Secretary, Mr. Charles N. Clarke, who replied:

"The ratio of white to dark hogs exhibited at our fairs the past three years, has been about $2 \frac{1}{2}$ to 71 , or about 25 per cent. white to 75 per cent. dark. I judge from observation and experience, that while the white hogs are not to disappear altogether in or from the Western States for many year's, they will be bred only in comparatively small numbers. I think while the old, large-boned white hogs are running out, small-boned breeds will work in."

Mr. R. C. Julson, Secratary of the Minnesota State 
Agricultural Sociely, in answer to inquiries, said, De cember 9th:

"I send rou the entries of swine as they appear on my books. Of Berkshires, there were 6 exhihitors; of PolandChinas, 8: of Essex. 2; of Sutfolks, 1: and of Chester Whites, 2-or, all told, 18 exhibitors of dark hongs, and 3 of whites, As to the number of animals, there were $2 \pi$ Berkshires, 2 Sutfolks, 26 Poland-Chinas, 3 ('hester Whites, and 5 kssex, or a total of 58 dark, and 5 white hogs."

Kansas Cily, Ho, has been for years famed for its Annual Exposition and Agrienlturil Finr, where hrecders of the most approved kinds of live stock have heen at great, pains to exhibit representalives from their herds and Hocks. For sercral years, Mr. Wm. Epperson has been the Superintendent of the Swine Department of the Exposition, and he mikes the statement that the pereentage of dark-colored hogs shown there has heen about as follows: In 18\%6, 90 pel cent.; in $18 \% \%, 85$ per cent.; in $18 \% 8,90$ per cent.; in $18 \% 9$, s5 per cent.; in 1880, all were black: in 1881, all were black.

Statements from the St. Ionis and other leading fairs showed. redatively, about the same conditions as to numbers as the foregoing, but the stock markets, and not the fairs, are the plices where it is pricticable to form really correct estimates of the color, quality, and numbers of the hogs that are raised from year to year. 'The fact that a good many whito hogs appear at the fairs may indicate that their owners are either men of superior energy and enterprise, or, to dispose of the stock, they have realized the need of such advertising an fair-going affords them. Kansas City is no mean hog market, and there were hondled at its stock yards, in 1881, ahout. 1. (i00,000 hemd. At our request, the Superintendent of the Stock Yards, Mr. H. P. Child. made some observiltions for ns, imel, Dee. "rth, wrote:

"Fortunately, for my plan, we had quite a heavy run this 
morning; and, taking advantage of it, I went tl sough our pens, and counterl all the hogrs that were from two-thirds to all white, and at the same time tallied the car-loads. In this manner, I found 491 white hogs seattered through 110 car-loads. Our run for the month just passerl was 1,678 cars, and 113,132 bogk, an average of over fif per car. Assurning these to be in the same ratio, grives us 7,330 for the 110 cars. This gives the proportion at 6.66 white, and 93.34 black hoge in every 100 hearl-a larger proportion than I restimated, my guess being about $t w o$ to the car, while this shows nearly four. This I consider a very correct estimate and critsion to gauge by, as the hogs that I looked over were received from all points and roads that feerl our market. I had not time, or really opportunity, to make seprarate restimates on localities, but I could see that they varied considerably, in that some few cars were very largely white, as high as 40 heal in one car, and from 20 to 30 in several others, while on the other hand I would pass load after load without a white hog in them. This is, of course, for the current year. I have no means of arriving at an estimate on preceding years, other than personal recollection, which would place the percentage in 1871 and 1872 at about half of each, decreasing to about 20 per cent. white in 1874, and a gradual clecrease to the present proportion from that time to 1881."

Most of our rearlers do not need to be told of the amount of business done at the Chicago Uniou Stock Yards, or of the millions and millions of hogs that pass through them. We askerl John B. Sherman, the longtime superintendent of those yards, to give his estimate of the ratio of white to black or dark hogs that had heen handled at the yards in 18\%9, 1850, and 1881, and lis statement is this:

"For the years mentioned, I will say, about 90 per cent. of hogs received at the Union Stock Yards were dark colored."

With a disposition to ascertain if the same great ratio of dark loogs would be shown by a later and more extronled connting at the Kansas City yards, Superintenront Child, on the sils of lebruary of this year (188:3), instructed his employés at the several scales to keep an 
accurate and separate account of all hogs weighed, in which the white or red color predominated, and report to him each evening. These numbers, deducted from the total, gave the number of black or dark hogs; the weighing ineluded all the hogs received up to the night of March 7th-one month-and aggregated 108,086 head, of which 5,36t were white, and $73 \%$ red, the percentage being 94.36 black, 4.96 white, and .68 red.

In speaking of the matter, Mr. Child said: "My report in 1881 made no account of red hogs, and all that were here at the time were classed with the blacks, so that to show just how much farther the black breeds have crowded out the white now than then, we must add the red to the black again, which gives us 95.04 against 1.96 per cent., or a gain for the black hogs in the year and a half of about one and seven-tenths per cent. I am not able to report, except in a general way, as to the difference in districts or on the several lines of railroad centering here, though the Northern part of Kansas and Southern Nebraska will run somewhat lighter in white than the above, and have very few red hogs, and my judgment is that over half of the latter come from Western Missouri."

'That Mr. Child's estimates are substantially correct, we have many times been satisfied by viewing in the yards of the great packing houses at Kansas City, where, in the large droves, amounting to thousands of head, purehased by them almost daily, it is oftentimes difficult to find as many as half a dozen on which the black does not predominate. At the same time, the red or santy-colored swine, so rare in the West a few years ago, are becoming slightly more common and more favorably considered.

[Personal observation conrinces ns that pratically the same state of affairs exists at this writing-1888. 'THe Author.] 


\section{CHAPTER XXII.}

\section{SOME GENERAL OBSERVATIONS.}

\section{ROOTING AND ITS PREVENTION.}

Nothing seems more natural to the porcine family than to spend a part of their time in rooting in the ground, and in this way they sometimes do great injury to pastures and meadows where they are kept or allowed to roam. Some way of preventing this has been found a necessity and has been the means of introducing numerous patented articles in the way of "Hog Rings," "Ringers," "Hog Tongs," "Hog Tamers," etc.

The patented rings are usually sold at prices not unrea. sonably high, but buyers of rings are impressed with the illea that, to use them succesirully, tongs, ringers, etc., must be bonght akso, and for these ontrageons prices ure charged, which, aitogether, makes the ring investment like the little parties that are sometimes made. where it costs one fire or ten cents to get in, and as many dollars to gat out.

A heary mitiress needle, in a stout handle, or the small blade of a good sharp pocket knife, answers every purpose for making the holes in the animal's nose, and new horseshoe nails, or common No. 12 wire, make rings as good as those covered by patents. If nails are used, they should be hammered into a circular form, preparatory to inserting, and when in, they can be closed with a pair of pincers.

If wire is used, it shou!u ug cl:t into pieces of proper length, put in, and ine ends fwisted with the pincers, on the awl near tine handle. The ends should be well twisted toget, nGr, and project half or three-quarters of an inch, as the ring will stay in better, and be more of an obrracle in the way of the hog in rooting. 
Mr. A. C. Moore describes three ways of preventing swine from rooting:

" 1 st. Place salt and wood ashes in some considerable quantity, at certain places on the ground, so that the earth will become saturated with the salt and lye. It will be found that the hogs will frequent these spots and work out some holes, but thereby satisfy their rooting desires, and the sod will be left undistudbed.

" $2 d$. Cut the rim of the snout with your pocket knife, slanting, as to the end and top of the nose, and leave both ends attached, so that the rim will slip up and down when the hog attempts to root. This method, in my experience, is less liable to allow the rim growing fast again, than when the cutting is done by a " hog tamer," provided it is done correctly.

" $3 d$. Put two rings in the snout. Buy common iron rings, such as are used by tinners, one inch in diameter, and when the rings are opened sufficiently, and the animal is secured with the usual cord loop on his nose, take a clip punch and make a hole on each side of the center and in the rim of the snout, insert the rings, and force the ends straight."

\section{EAR MUTILATION AND EAR MARKING.}

We wish to enter our protest against the practice so common with many farmers, of cutting and disfiguring the ears of their hogs in a brutal manner, under the plea that without it they could not distinguish their own hogs.

It is desirable to have some mark by which the owner may know his own, and a small hole or slit, in some certain place in one ear, need not disfigure it, and yet be just as reliable for identification as the horrible carving and mutilation of both ears.

Well bred hogs have, naturally, fine ears, which adl much to their appearance of uniformity and quality, and it seems to a lover of good stock almost like sacrilege to have them mangled, as is sometimes done by savage dogs and more savage men.

SOWS EATING THEIR PIGS.

No one but the breeder who has had the misfortune to see a fine litter of pigs destroyed by their dam-herself 
perhaps the best sow he has-can have a sense of the annoyance and bitter disappointment such an occurrence involves.

Of such cases a monthly Report of the Department of Agriculture says :

"It is well known that sows not unfrequently attack and destroy their young; or, if prevented from this, will not let dowu their milk, so that the young pigs necessarily die from want of nourishment. When this condition of things is not caused by a diseased condition of the uterus, it is said that the sow can be brought to terms by pouring a mixture of ten to twenty grains of spirits of camphor, with one to three of tincture of opium, into the ear. The sow will immediately lie down on the side to which the application was made, and remain quiet in this position for several hours, without interfering with ber pigs; and on recovery from the stupor, will have lost ber irritability in regard to them. The experiment has been tried in Germany hundreds of times, according to one of the agricaltural journals, without any injurious effects. It is also said that the eating of pigs by the parent sow can be readily prevented by rubbing them all over with brandy, and making the same application about the nose of the sow herself."

John Boynton, of Stephenson Co., Illinois, describes the way in which he saved a litter of pigs from a vicious sow, as follows:

"I have a fine Chester White sow that has devoured several pigs of other sows, and as she was heavy with pig herself, I expected that when she littered, she would eat them as fast as she could get to them, I watche'd her closely; she walked up to the first pig and very deliberately opened her mouth wide to take it in. I screamed at her, and she then turned upon me. I continued to menace her until she had to lay cown to have another pig; I then got quietly into the pen, and as she was naturally very gentle, I succeeded in gettiug the pig to her teats, and so I stayed with ber constantly, all the while petting the sow, aud as fast as the pigs came, would divest them of their entanglements and place them at the teats, which they took right hold of, and before the sow was aware of it, a maternal affiction was enkindled in her heart for her offspring. She had, and saved, eight of the finest pigs I ever saw. They are now over two weeks old, and the mother feels all the affection necessary for them. It is well to treat sows gently 
at all times; then at "littering" time jou can do what you please with them."

\section{QUARRELSOME AND FIGHTING HOGS.}

When a considerable number of hogs are penned together for fattening, the owner is sometimes much annoyed by finding them disposed to chase and bite one another, and occasionally, to such an extent, that those least able to defend themselves, are chased and worried to death.

We have not been troubled in this way with our own hogs, but as suggestive to those who are, we present the following from "Berkshire," (a most intelligent breeder, withal), of Ridge Farm, Ills. :

"Fifteen years ago, I began feeding a large number of hogs on floored pens, around a flouring mill, and they commenced biting each other. One hog would give anotler a bite, when he would run and squeal, and each hog he passed near would give him a bite. and thus they kept the poor animal going, mutil he died. I would go to the pen and stop them, but they would soon commence again.

"I concluded they were feverish, which caused them to be rest. less, and that they bit each other for the want of something to cool their fever.

"I tried a variety of remedies, and at length fed them some stòne coal, which effected a complete cure. I have continued, ever since, to feed my hogs all the coal they would cat, and have never had any more trouble with their biting each other."

THE CONDITION NF SOWS FOR BREEDING.

In our efforts, in years past, to get all the information possible about swine, and their management, we were always confronted with the statement tiat, a sow tolerably fat at the time of taking the hoar, would have bit few pigs, and they of such inferior quality as to be worihless, while it was more than likely that the sow and pigs both would be lost.

Hearing this so much, we concluded that what erery: body said, must be near the truth.

We are not so positive about this as we were. 
Tro neighbors raise some model Berkshires, and running a flouring mill, have an abundance of the best of feed, which they use liberally with their breeding sows, keeping them in pretty good bacon order all the time. We used to feel that we were doing a good stroke of missionary work, when we cautioned them about keeping their sows in so much flesh, and that barrenness and failure were sure to follow. They accepted the advice kindly, but continued to feed their sows liberally, and in spite of it all, raised a plenty of good pigs.

Two sows that the thought very highly of, were kept uncommonly fat, and we selected these two as the ones to illustrate our argument, and show by their non-breeding that they had been entirely too well kept.

When the sows farrowed, one had fourteen, and the otler fifteen strong pigs, and since then we have labored but very little to convince these gentlemen that "a fat sow wou't breed." It has been their turn to laugh.

We cannot doubt that hogs kept and fed at flouring mills, get much nearer a perfect food, than those kept on corn exclusively, and especially is this true of brood-sows and pigs.

\section{IS IT PROFITABLE TO CURE PORK?}

Mr. Thomas Wood furnishes us an account of an interesting experiment made by him, as follows:

"A few years ago I made an experiment or two, in order to find out whether it was most profitable to sell my pork or to make bacon of it, and then sell at the prevailing prices.

"I killed a Chester White hog that weighed, dressed, $440 \mathrm{lbs}$. pork, worth \%c. per lb. — $\$ 30.80$. When cut up for salting, the different parts weighed as follows:

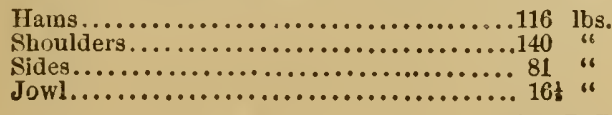


"Learing $86 \% / 2$ bs. weight of lard, ehine, or back bone, ribs, face, feet, and other trimmings, worth se. per lb.\$4.3\%.

"'lhe meat, when cured, was hung in a smoke-lionse for six weeks, then sold and weighed, as follows:

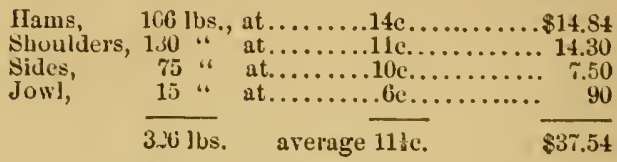

Value of bacon sold............................. \$37.54

Value of trimmings...................................... 4.82

Total.................................... $\$ \$ 11.86$

Value of the pork at market price....................... 30,20

Profit on making the pork into bacon...............\$11.06

"This hog was about fifteen months old, and the shrinkage in weight in making bacon was 27 lbs.

"At the same time I killed a pig five or six months old, in order to ascertain the difference in shrinkage.

The rig weighed dressed................................ 140 lbs. When eut up, the hams, shonlders, sides, and fowl weighed.....111 "

Leaving the weight of lard, chine, face, feet, and trimmings.... $: 9 \mathrm{lbs}$.

"The meat weighed just the same when taken out as when put in the salt tub; when dried and smoked the same length of time as the other hog, the weight was as follows :

Hams, $\quad 31$ lbs., sold at......1tc. per lb.........\$t.3t

Shoulders, 28 6" "6 .....11e." " ........ 3.08

Sides, 30 " " 6 .....10c. " " $\ldots \ldots \ldots . .63 .00$

Jowl, "6 " 6 " 6 ...6. "

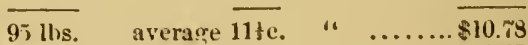

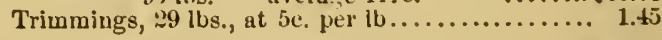

$\frac{12.23}{\$ 12.20}$

The pork, 140 lbs., at 7c. per Ib., was worth..... 9.30

Profit on making pork into bacon........... \$3.43

"From this it appears that the shrinkage is proportionately much greater in the pir pork, than in the pork of 
the older and more mature hog, also that there is a greata proportional weight of trimming."

\section{REPOILS' OF REMARKAIBLE GROWTH.}

In the Jinuary (18\%6) Number of the National Live Stock Journal, a correspondent published an item stating that Mr. $\Lambda$. Messer, of Mankato, Minn., had just butch. ered a thorough-bred Berkshire pig, live months and twenty-three duys old, that weighed, when dressed, 32:3 llosThis was such a marvelons story that we were incredu. lons enough to doulst it, and took early occasion to call through the same journal, for some further proof than the ex parte statement of one (possibly rery much interested) individual. Other breeders also insisted that, if such a feat had been accomplished, the parties cognizant of it should certify to, and make public what they knew.

This elieited an affidarit from the man who bred the pig, as to its age, one from Mr. Messer, who raised and fed it, as to its identity, and another from the butcher who dressed it, as to its weighing the 323 lbs. net, all three of which substantiated, in effect, the original statement. After this, the breeler's of fine Berkshires throughout the country, who had never raised a pig to lialf that weight at the same age, demanded to know how such rapid and enormous growth had been produced, and in course of some months it was published to the world in the following language :

"He was kept in a lot $15 \times 20$ feet, with a few boards laid over one corner, to form a shelter, and under this shelter was a good bed of straw. The pig was kept in these quarters until the weather became cool, when a comfortable little sty was built in one corner, $6 \times 6$ feet. The pirs was fed on the swill fron the house, with corn neal stirred in; but had no cooked food whatever, except pieces of bread from the table, which were thrown into the sw.ll.

"He was fed regularly three times a day, and had all he would eat. He would eat all he could, then go grunting to bis bed of straw-lie down, and continue to grunt. In fact, the most of the pig's time, was spent in gruutiug, eating, and growing." 
Although accompanied by proof, this statement sur. passes onr belief, as it scems beyond the range of hmman possibilities that such extraordinary pigs ean be produced by any sneh ordinary means, and we take the responsibility of advising our farmer friends, when looking around for extre gool pigs to breed from, to diseount such stories as the foregoing at least 50 per cent.

\section{PRIZE ANIMALS FOR BREEDING.}

It is a very common pratice with firmers and breeders to attend the County, State, and Inter-state Fairs, for the purpose of selecting, from those on exhibition, swine for breeders, and it is considered quite an achievement to attend one or more of the prominent expositions and take home to the farm the pig, or pair of pigs, decorated with the blue ribbon. They look fine, and are fine, but not - fine enongh to offset the disappointment and chagrin of the credulous buyer, who, after patient effort, fails in nine eases out of ten, to erer produce from them any stock that looks as those did at the fair.

The show-yard may be the best place to see and buy stock for show purposes, but not for breeding.

Only the initiated know the rarious and peeuliar methods employed, in fitting up those animals to which were awarded preminms, over such strong competition as they encomnter at leading fairs. We recently conversed with a breeder, whose greatest triumph in life had consisted in having premimms awarded to two of his pigs, at one of the great St. Lonis fairs.

He said he "scooped" all competitors, and garo the following as some of the methods used to produce such meritorious(?) :mimals :

"T'They were fed on beefsteak, ent into small bits, and dropped into new walm mill, is much, and as often as they would eat. They had daily a bath of warm, soft water and castile soap, after which their hair was dressed with ulive, or sweet oil." 
Premium pigs, produced by such trentment, afterwards getting only common fare, do but poorly indeed, and to expect them to reproduce a family of show pigs, is to cherish a dream that will fail of realization.

Breeders of fine swine, as of fine cattle, frequently sacrifice their hest animals for show purposes, and their preparation for this, in a majority of eases, unfits them for thereafter sucecssfully reproducing their kind.

\section{FHEDING COOKEI WHEAT.}

The following statement, of remarkably rapid gain in weight from feeding hogs on conked wheat, is given by a corresponrtent of the C'incinnali Gazetle:

"On the 4th of August, 1870, I put up 15 hogs, weighing 2,400 lhs., and fed them 5 t bushels cooked wheat the first week. On the 11 th their weight was 2,600 lls.s, gain, $200 \mathrm{llss}$, or a gain of 13 f $1 \mathrm{hs}$. to the hor, being nearly $2 \mathrm{lbs}$ a a day. The next week I fed them 6 hushels of the cooked wheat, producing an increase of $215 \mathrm{lbs}$, or $14 \mathrm{t}$ lbs. to the hog, heing a gain of over 2 lhs. per hear a day. The third week I fed them 10 bushels of cooked wheat, resulting in a gain of $260 \mathrm{lbs}$, or $17 \frac{1}{8} \mathrm{lhs}$. a head, or $2^{10} / 21$ a day. The fourth week I fed them $11 \frac{1}{6}$ bushels of cooked wheat, the gain being $320 \mathrm{llss}$, or $21 \frac{1}{3}$ lhs. a head, or a fraction over $3 \mathrm{llhs}$. a day each. The hogs were then soll and taken away. They gained in four weeks 995 lbs. on $32 \frac{1}{2}$ hushels of wheat. In this manner of fecding I received a good price for the wheat, as the hogs were sold at \$8.25 per $100 \mathrm{lhs} . "$

\section{IIOGGING OFF COIN FIELDS.}

The IIon. J. M. Millikin, in the National Live Stock Journal, writes as follows:

"I am aware that the people who reside in the Fast, where grain is ligh, will be greatly shocked to think that any one wonld presume to say anything in behalf of such a 'lazy, wasteful, and untidy' mode of using a crop of corn. Indeed, western men can bo found who will denounce the unfarmer-like proceeding in unmeasured terms. But let us see if something cannot be said in support of what some may regard as a very objectionable practice.

"In managing our farming operations, there ure two things that should not be lost sight of: 
"First.-We shoulıl aim to so manage our affairs as to realize a good profit on our lahors and iuvestment; and

"Secondly. - To so cultivite our land as to maintain, if not to increase, its productiveness.

"If you have a field of corn of a size suited to the number of hogs you intend to fatten, supplieil with water, there is no plan. you can adopt of feeding said corn to your hogs that will produce better results than by turning your hogs into the field, where they can eat at their pleasurc. As a rule, the weather is generally good in September and October. If so, there will be no loss of grain, while the saceharine juice of the stilks will eontribute somewhat to the improvement of the hors. The expense saved in gathering the corn, and in giving constant attention in feeding, is quitc an important item to any man who has other pressing work to perform. Besides, hogs turned into a field for fifty or sixty days are likely to do better than they will do under other ordinary circumstances.

"There is no plan of using the products of a corn ficld better calculated to maintain its fertility than the hogging-off process. Everything produced off the ground is returned to it; and if the proper mode is adopted of plowing everything under in the fall, the soil will be improved rather than impoverished. 'This is my theory upon the subjeet, which is sustained by my experience and observation, and which I have occasionally urged on the attention of others.

"A very few days since I was in conversation with some farmers upon this subject, when a very reliable, careful, and excellent farmer gave this account of his own experience, which I give, with the remark that his statements are entitled to the fullest confidence. He said: "I have cultivated one field eleven successive ycars in corn, and every fall turned in my fattening hogs, and fed it off. My crops of corn rather increased than diminished. In the spring, after feeding off the corn for eleven years, I sowed the field in spring barley. I had a crop of forty bushels per acre. I plowed the barley stubble under, and sowed the same field in wheat. The next harvest I bad a crop of wheat of forty-tuco and o half bushels per acre.'

"Thus you have the theory, the practiec, and the result, of the logging-off process."

THE RELATION BETWEEN THE PRICES OF GORN AND PORK.

While it is perhaps true, that the bulk of the corn fur to hogs does not give a return of ten pounds of pork, 
live weight, to the bushel, it is established that a bushel of corn will make that much, and more, if properly handled, and where it does, the following will serve as a basis for careful calculations :

We present it for what it is worth, and think it may be approximatively correct.

- Feeding corn worth $121 / 2$ cents per bushel, makes pork costing $1 \frac{1}{2}$ cent per pound.

Feeding corn worth 17 cents per bushel, makes pork costing 2 cents per pound.

Feeding eorn worth 25 cents per bushel, makes pork costing $21 / 2$ cents per pound.

Feeding corn worth from 33 to 40 cents per bushel, makes pork costing 4 cents per pound.

Fceding corn worth 50 cents per bushel, makes pork costing 5 cents per pound.

Or: pork at 5 cents per pound, gross, gives 50 cents per bushel for corn.

At 4 cents per pound, gross, gives from 33 to 40 cents per bushel for corn.

At $21 \%$ to 3 cents per pound, gross, gives from 25 to 30 cents per bushel for corn.

\section{RECORDS AND RECORDING.}

Beginning with the organization at Springfield, Illinois, in 1875, of the American Berkshire Association, great attention has been paid in America to recording pedigrees of thorouglibred breeding swine. The value and importance of this are not only quite generally concerlert here but also in Lngland, where the British Berkshire Association, following the Yankee example, has already issued ten volumes of herdbooks.

At this writing (Jannary, 1897) there have been issued 
fourteen volumes of the American Berkshire Record, containing pedigrees as follows. The table also shows the number of pedigrees in the editor's hands for entıy in Volume XV:

\begin{tabular}{|c|c|c|c|c|}
\hline & & Boars. & Sou's. & Total. \\
\hline Volume & I. $. \cdots, \cdots, \cdots, \cdots, \cdots$ & 235 & $5+1$ & 776 \\
\hline & II $\ldots \ldots \ldots \ldots \ldots \ldots \ldots \ldots$ & 523 & 1,272 & 1,795 \\
\hline “ & III $\ldots \ldots \ldots \ldots \ldots \ldots \ldots$ & 480 & 870 & 1,350 \\
\hline “ & IV $\ldots . . . . . \ldots \ldots \ldots \ldots$ & 420 & 735 & 1,155 \\
\hline " & $\mathrm{v}, \ldots \ldots \ldots \ldots \ldots \ldots \ldots$ & 390 & 780 & 1,170 \\
\hline “ & vi $\ldots \ldots \ldots, \ldots, \ldots, \ldots$ & 457 & 815 & 1,272 \\
\hline “ & vı1 $\ldots \ldots, \ldots, \ldots, \ldots, \ldots$ & 693 & 1,307 & 2,000 \\
\hline "4 & 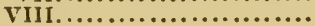 & 676 & 1,324 & 2,000 \\
\hline “ & $1 \mathrm{x}, \ldots, \ldots, \ldots, \ldots$ & 1,155 & 1,845 & 3,000 \\
\hline “ & $\mathbf{x}, \ldots \ldots, \ldots, \ldots, \ldots, \ldots, \ldots$ & 1,042 & 1,958 & 3,000 \\
\hline “ & 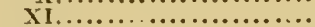 & 1,167 & 1,833 & 3,000 \\
\hline “ & XII $\ldots \ldots \ldots \ldots \ldots \ldots \ldots$ & 1,077 & 1,923 & 3,000 \\
\hline “ & 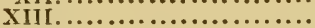 & 1,289 & 2,711 & 4,000 \\
\hline " & XIV $\ldots \ldots \ldots \ldots \ldots \ldots \ldots$ & 1,582 & 3,418 & 5,000 \\
\hline “6 & Xv. $\ldots \ldots \ldots \ldots$ & 903 & 2,118 & 3,021 \\
\hline Total in & fifteen volumes........... & 12,089 & 23,450 & 35,539 \\
\hline
\end{tabular}

The National Berkshire Record, an offshoot of the American, has issued two volumes, containing pedigrees of 535 boars and 1050 sows. In the ten rolumes of the British Berkshire Herdbook, so far received, pedigrees have been recorded as below:

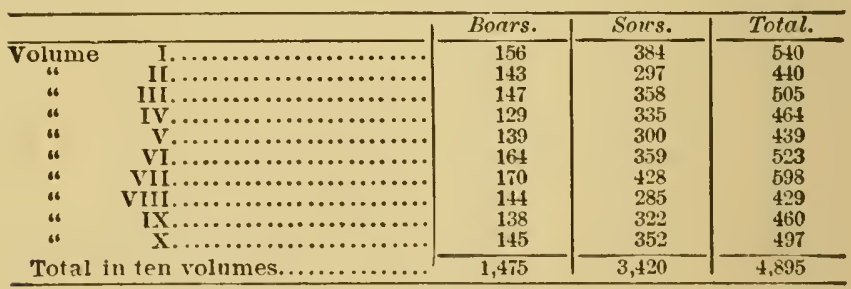

Poland-China brecders have established four separate Records, with different rules, editors and management, instead of coöperating and making one Record and one system of rules, as wonld seem desirable for any breed. The "Ohio Poland-China Record," having headquarters at Dayton, 0 , and begun in 187\%, has issued already seventeen volumes, with peligrees of 64,000 animals.

One designated as the "American Poland-China 
Record," and thus far published in Iowa, has sent out sixteen volunies sirce 1878 , recording 63,000 pedigrees.

A third, known as the "Central Poland-China Record," had its beginning in Indiana in 1880, and its sixteen issues contain nearly 27,000 pedigrees.

The "Northwestern Poland-China Record," established in Kansas in 1881, but since suspended, issued three volumes.

The fifth and latest established (1886) of these PolandChina Records is named the "Standard," published in Missouri, and its nine volumes are made up of 45,000 pedigrees.

Two Records for Chester Whites have been established -the "Standard" and the "American." The recording done in the "Standard's" five volumes is as follows:

\begin{tabular}{|c|c|c|c|c|}
\hline & & Boars. & Souts. & Total. \\
\hline Volume & I. & 2,642 & 2,812 & 5,454 \\
\hline “ & III.: & $\begin{array}{l}245 \\
152\end{array}$ & $\begin{array}{r}265 \\
260\end{array}$ & $\begin{array}{l}020 \\
412\end{array}$ \\
\hline “" & ….... & $\begin{array}{l}224 \\
2218\end{array}$ & 400 & 624 \\
\hline \multicolumn{2}{|c|}{ Total in five volumes } & 3,481 & 4,159 & $7.640^{-}$ \\
\hline
\end{tabular}

The "American"-originally founded as a "Record of Todd's Improved Chester Whites," which were a combination of the Penusylvania Chester Whites with other white hogs in Ohio, of previously mixed or miscellaneous breeding, since 1865-67-has also published five rolumes, mate up as here shown :

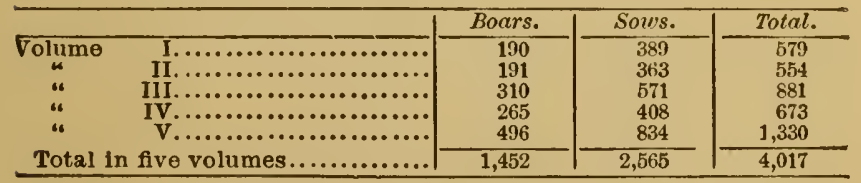

The red, or rather sandy, hogs common in America, are by their breeders now designated as Duroc-Jerseys, and two different Records of their pedigrees are now published. 
The American Duroc-Jersey Swine Breeders' Association has issued five volumes of its pedigree records, with numbers as below :

\begin{tabular}{|c|c|c|c|c|}
\hline & & Boars. & Sou's. & Total. \\
\hline Volume & I. $\ldots \ldots \ldots \ldots$ & 300 & 1.000 & 1,300 \\
\hline & II $\ldots$ & 400 & 1,000 & 1,400 \\
\hline “ & III,$\ldots \ldots \ldots \ldots \ldots \ldots \ldots \ldots$ & 430 & 1,000 & 1,430 \\
\hline “ & IV $\ldots \ldots \ldots \ldots \ldots \ldots$ & 483 & 1,000 & 1,483 \\
\hline “ & $\mathbf{v} \ldots \ldots \ldots \ldots \ldots$ & 475 & 1,000 & 1,475 \\
\hline \multicolumn{2}{|c|}{ Total in five volumes .............. } & 2,088 & 5,000 & 7,088 \\
\hline
\end{tabular}

'The National Duroc-Jersey Association has issued two volumes of a record containing:

\begin{tabular}{|c|c|c|c|}
\hline \multirow{3}{*}{ 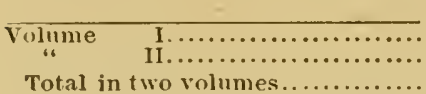 } & Boars. & Sou's. & Total. \\
\hline & $\begin{array}{l}175 \\
450\end{array}$ & $\begin{array}{l}450 \\
850\end{array}$ & $\begin{array}{r}625 \\
1,300\end{array}$ \\
\hline & 625 & 1,300 & 1,925 \\
\hline
\end{tabular}

'I'wo volumes of a Record for the "Victorias," originating in Indiana, have been published, and a third is well towards completion at the time this is written. The following shows the number of pedigrees in each of the two volumes:

\begin{tabular}{|c|c|c|c|}
\hline & Bnars. & Sou's. & Total. \\
\hline 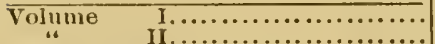 & $\begin{array}{r}34 \\
360\end{array}$ & $\begin{array}{r}69 \\
566\end{array}$ & 103 \\
\hline Tcotal in two volumes ............. & 394 & 635 & 1,029 \\
\hline
\end{tabular}

An association of Suffolk breeders is expecting to issue the first volume of a Record containing about 350 pedigrees.

The American Essex Association has two volumes with this showing:

\begin{tabular}{|c|c|c|c|c|}
\hline & Boars. & Solos. & Total. \\
\hline Volume & 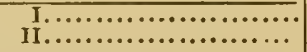 & $\begin{array}{l}118 \\
150\end{array}$ & $\begin{array}{l}233 \\
257\end{array}$ & $\begin{array}{l}351 \\
407\end{array}$ \\
\hline Total in & two volumes............... & 268 & 490 & 758 \\
\hline
\end{tabular}


Of the popularity of these various Records, no better evidence is needed than the fact that they are well sus. tained, and financially prosperous. The prices of the volumes range from $\$ 2.00$ to $\$ 5.00$ each, and we believe the fee for recording in any of them is ordinarily $\$ 1.00$ for each pedigree, except that some of the Reeord Asso. ciations make a special rate of one-half to their shareholders.

\section{STANDARDS OF EXCELLENCE AND SCALE OF POINTS.}

Associations of those representing or interested in each of the improved breeds of swine have formulated a standard of excellence or scale of points for their favorites, with about twenty divisions, aggregating one hundred in an animal estimated as perfect in all its points, and it is by these standards that they desire their swine judged at exhibitions.

Below is the standard adopted for Berkshires by the American Berkshire Association, the figures representing the comparative value of each point when perfect:

CoLon-Black, with white on feet, face, tip of tail, and an occasional splash on the arm .............................................

FACE AND SNOUT-Short; the former fine and well dished, and broad between the eyes ................................... 7

EYE-Very clear, rather large, dark hazel or gray ................. 2

EAR-Generally almost erect, but sometimes inclined forward with advancing age; medium size; thin and soft ................. 4

JowL-Full and heavy, running well back on neck ................. 4

Neck-Short and broad on top............................... 4

HAIR-Fine and soft; medium thickness ...................... 3

SkrN-Smooth and pliable.................................... 4

SHovLDER-Thick and even, broad on top, and decp through

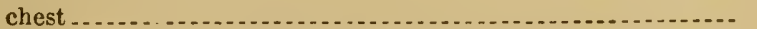

BACK-Broad, short and straight; ribs well sprung, coupling close up to hips .... . . . . . . 8

SIDE-Deep and well let down; straight on bottom lines........... 6 FuANK-Well back, and low down on leg, making nearly a straight line with lower part of side .............. 5

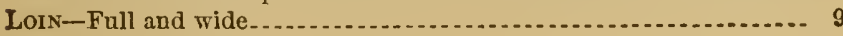


HAM-Deep and thick, extending, well up on back, and holding thickness well down to hock .............................. 10

TAIL-Well set up on back ; tapering and not coarse .............. 2

LEGS-Short, straight and strong; set wide apart, with hoofs erect, and capable of holding good weight

SyMMETRY-Well proportioned throughout, depending largely on

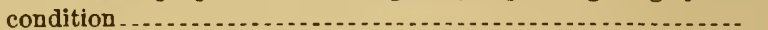

Condition-In a good, healthy, growing state; not overfed ........ 5 STYLE-Attractive, spirited, indicative of thorough breeding and constitutional vigor.........................................

ToraL

The following was recommended by the National and has been adopted by the various other Poland-China Associations for that breed :

CoLOR-Dark spotted or black ........................ 3

HEAD-Small, broad, face slightly dished ................ 5

EARs-Fine and drooping ............................ 2

JowL-Neat and full ................................ 2

NECK-Short, full, elightly arched..................... 3

BRISKET-Full ........................................... 3

SHOdLDER-Broad and deep .......................... 6

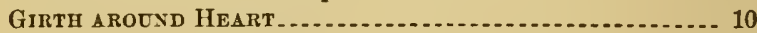

BACK-Straight and broad............................ 7

SiDEs-Deep and full

Ribs-Well sprung...................................... 7

Loin-Broad and strong.............................. 7

BELLY - Wide and straight ........................... 4

FuANK-Well let down.............................. 3

HAM-Broad, full, and deep............................. 10

TAll-Tapering, and not coarse ........................ 2

LIMBS-Strong, straight, and tapering .................... 7

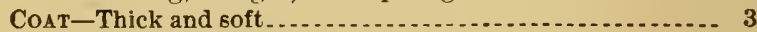

Acrion-Prompt, easy and graceful ..................... 5

SYMMETRY - Adaptation of the several parts to each other.. 5

TotaL..............................................

The Chester White Association (Todd's) uses the fol. lowing :

HEAD-Small, broad, slightly dished .................... 7

EAR-Thln, fine, drooping .......................... 2

JowL-Neat and full.................................... \& 
NECk-Short, full, well arched ....................... 3

BRISKET-Full and deep.............................. 3

SHodLDEk-Broad and deep.............................

GIRTH AROUND llEART ............................ 9

BAck-Straight and broad............................ 6

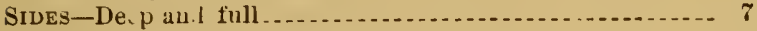

RiBs-Well sprung..................................... 6

LoIN-Broud and strung ......................... 7

BELLY - Wi.le and straight ........................... 5

FLANK- Well let down ......................... 3

HAN-Broad, full, and deep _....................... 10

Linbs-Strung, stl"aight, and neat ...................... 6

TAlL-Tapering, and not coarse ..................... \&

Cost-Fine and thick ............................. 3

Color-White

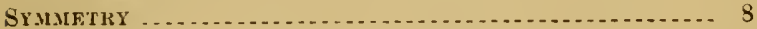

TOTAL $\ldots \ldots$

'The ssociation of breeder's of red swine, whicis the, haie officially designated and now record as Duroc..Jer seys, hats adopted the following scale :

Colok -Cherry red with ut other admixture .............. 5

Ilc.1-Nuse fine and short; face slightly dished, wide be-

tween eyes . . . . . . . . . . . . . . 10

Ear3-. Ie dium size; not erect nov fon drooping........... 5

CheEk-Large, full and well rounded ................. 5

Neck $\rightarrow$ Short ; evenly deep from poll to shouhleri......... 5

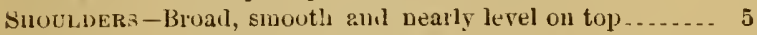

Cues -Deep; filled level behind shonlders............. 10

Bacl-Broad; straight or slightly arching, carrying even

wi.th tu hips.................................... 10

Sides-Deep; medium longth level between shoule ers and

lips . . . . . . . . . 10

BELI.Y -Straight underline; not paunchy ............... 5

Hays-Large, full, well rounded; extending well to bock

joint ...................................... 10

LEGS-Merlinm bone; short, straight, well up on toes..... 5

TAIL-Set medium high; nicely tapering from base ........ 5

HAIr-Fine, soft, straight; moder:tely thiek........... 5

ACTion-Vigorous, animated, sprightly ................. 5

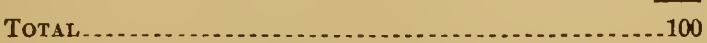

Viewing the accompanying di:lgram will suggest the 
points and method of applying the standard, approximately, to swine of almost any breed:

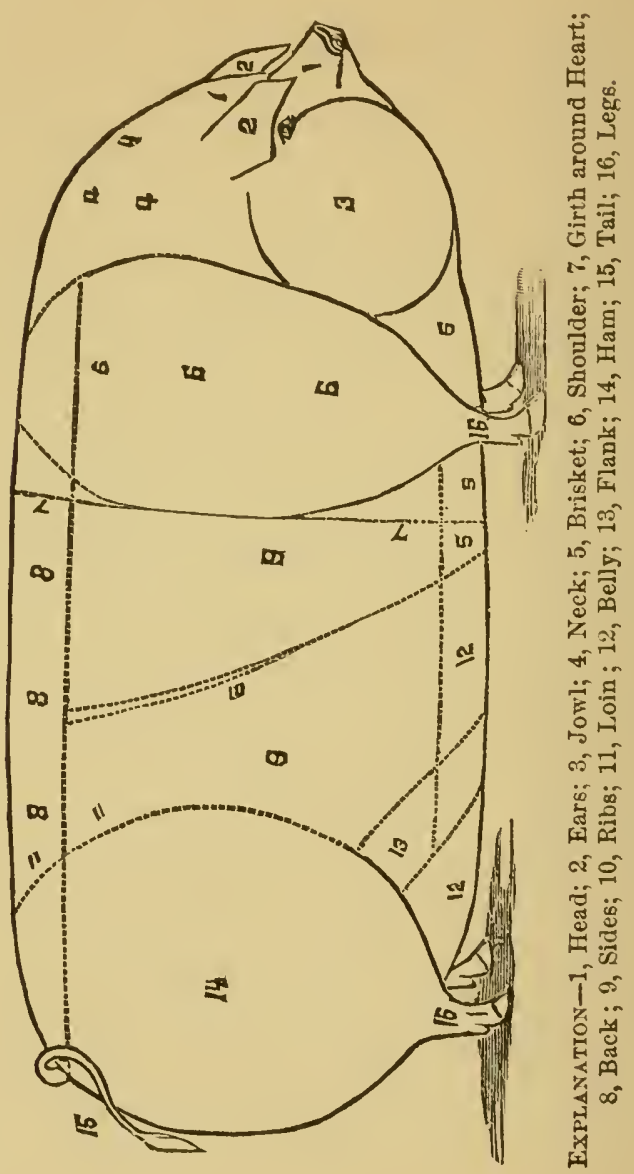




\section{COST OF PIG AND PORK.}

In recent issues of the Breeder's Gazette three different swine-raiser's presented statements, each from his own experience, intended to show the cost of young pigs, and also their cost when matured to marketable porkers. 'The first one, Mr. A. G., makes lis figures like this :

"Ten sows, four months old, cost ..................... $\$ 100$

Interest on the investment, 10 per cent ................... 10

Keep of same one year, 25 bushels of corn each at $30 \mathrm{c} . . . . \quad 75$

Keep, interest on cost and shrinkage on boar............. 10

Extra feed for pigs up to two months old................ 15

Loss on sows, 20 per cent............................ 20

Cost of pens, $\$ 50$-interest and repairs, 20 per cent....... 10

Total ....................... $\$ 240$

"Allowing fifty pigs from the ten sows, and a loss of thirty per cent up to two months old, and we have thirty-five pigs, costing $\$ 140$, or $\$ 4$ each. Allowing a pig at two months to weigh thirty pounds, and nine pounds of pork to a bushel of corn, we will feed him thirty bushels of corn to make him veigh 300 pounds.

"Then we have cost of pig ........................... \$4

Thirty bushels of corn at 30 cents ...................... 9

Total

.813

"If we add twenty per cent to this to eover the items of labor, taxes, interest and risk after two months old, we have the cost of the 300-pound hog when fit for market, $\$ 15.60$, or five and a quarter cents a pound, searly.

"From above calculations pork will cost as follows, nearly:

"Corn at 15 cents, pork will cost................. 3 cents per lb.

Corn at 20 cents, pork will cost. 316 " 6

Corn at 25 cents, pork will cost. 41668

Corn at 30 cents, pork will cost .............54 " "

Corn at 35 cents, pork will cost..............6 " " 
Swine-raiser number two responds in this way:

"Forumately, ten sows, the number Mr. A. G. has given in his estimate, is the exact number I kept for several years; but I suceefled in raising to maturity just double his number of pigs to each litter. I usmally "aise two litters each year, one to come in February and he other in July. My February jigs I fitten the folsowing antumn, and those that come in July are liept through the winter and fed for market the next summer and fall. I think his estimate for the cost of sows-\$10 at four months old-is pretty steep for three cent pork. I can always buy sows at that age, suitable for raising pigs, for less tham half that amount on a basis of three cent pork, and can raise them eheaper than I ean buy. For the salie of eomparison I will give the items of expense incurred in raising the little pig:

"Ten sow pigs, four munths old ...

Interest on the investment .................... +00

Keep of sows 9 munths, 15 bushels corn each, $30 \mathrm{c} \ldots \ldots . .40 .50$

To pasturing on grass three months ................ $\quad \tau .50$

Iulerest on cost aud keep of boar ................ 8.00

Extra keep of pigs to three munths old.............. 30.00

Total

$\$ 1+0.00$

"Allowing seventy pigs to ten sows we have the cost of pigs $\$ 140$, at $\$ 2$ apiece at three months old. Itemized the accomnt will stand thus :

" Cost of pig at three months........................ \$2.00

Keep fur six months, seven bushels corn, at $20 \mathrm{c}$........ 2.10

Two month's s'un on elover.......................... 50

Fifteen bushels corn to prepare for market ............., 4.50

Total

$\$ 9.10$

"Thus it will be seen we have the pig ready for market at fourteen months old, and he will weigh 300 pounds-a cost of a fraction over three cents per pound 
for pork. I have made no allowance for the loss of pigs; but I have only counted one litter to each sow in a year, and given the other litter, which will more than make up for all losses of pigs and sows, and interest on cost of pens; although I have no extra expense for pens, as my hogs have access to the fields the year around with other stock. I regard the manure from the hogs that have the run of the pastures throughout the year as more than equivalent to any pickings that they may get while being fed eorn."

Respondent number three presents the results of his experience as follows:

"My experience is that I cun buy ten sows, eight months old, at $\$ 10$ each, and four months later have ten litters averaging seven pigs, or seventy pigs in all. Allowing a loss of thirty per cent np to two months old, at which age I wean them, I have forty-nine pigs to fatten. Now how much have these pigs cost me? I figure it this way:

"Interest on the investment, at 10 per cent............. 10.00

Keep of ten sows one year ....................... 60.00

Keep and iuterest on boar .......................... 10.00

Extra feed on young pigs up to two months........... 10.00

Loss on sows. (This is counterbalanced by the fact that

they will be in pigagain.) . . . . . . . . .

Interest, repairs aud labor ......................... 20.00

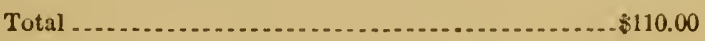

"At these figures my young pigs cost me almost xactly \$2.25 each. For the next two months I feed these pigs a slop of oats, bran and middlings, costing:

"Feed for two months

Labor, etc

Total. 
"Now I lase forty-nine pigs, four months old, arer. aging seventy-tive peonds, and iosting me about \$3.35 each. From this time on I feed them corm, twenty-tive bushels eath, on which they gain 9 ?5 poumds, and at a rear old they arerage 300 pounds. and at the following cost:

Cost per hesul at four muths ..........................

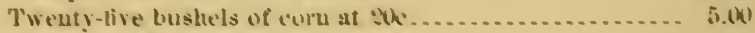

I.sbor, ete., per lesth.... ........................... 1.(ti)

Tintal

sin

"Nine dollars and eighty-eight cents is the total cost of my 30()-pound hog. I cam sell him at our locenl market at \$4.:0 (present prices) pere 100 pounds, or \$1:.50 net. I bo not feed my brood sows corm in any large quantity, preferring a slop of oats, ham and middlings :me an oceasional mest of roots. 1 tind this less expensive th:m erom and I believe less injuriuss. I pay but twenty cents for corn, and sale something in not feeding it to my sows. As I hate figured in my estimate the interest and cost of keeping my sows and hosr for one rear, the second litter will cost only labor and focd for the two months, which amounts to $\$ 30$ for the forty-nine little pigs, or sixty-one cents exeh. My tirst litter cust me $\$ .2 .85$ eneh at two months old, and this will bring the arerage cost of all my little pigss, at two months old. down to \$1.43. To prove that I am approximately correct. two-months-old pigss can readily be bonght in our neighborhood for s:? eateh."

\section{STOCK YALDS RECEIPTS.}

The table on the next page shows the amual and total receipts of hogs at the two greatest live stock markets in the workd-the Union Stock Yards, at 
Chicago, Illinois, and the Kansas City, Kansas, Stock Yards, since tineir establishment:

Chicagn, Ill. Kanwas City, Kem,

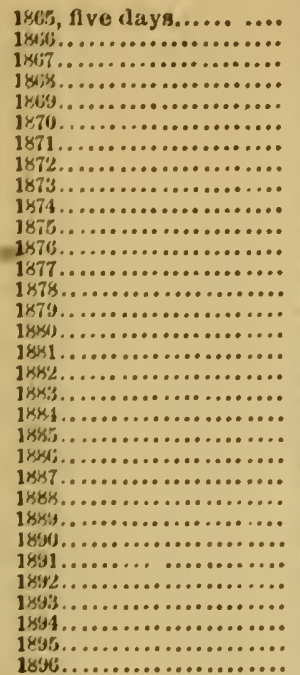

$17, \pi 0 \%$

(6) $1,7.16$

$1,696,7348$

$1,70 M^{3}, 7 x^{2}$

$1,1,1,84 ; 3$

$1,603,15$ \&

,

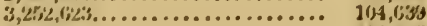

$4,4: 37,7,1 . \ldots \ldots \ldots \ldots \ldots \ldots . .221,815$

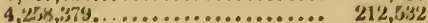

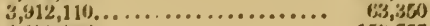

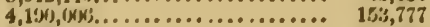

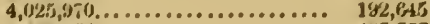

6,335,64.................. 427,777

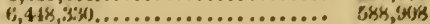

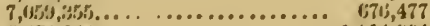

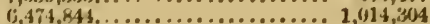

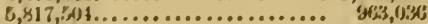

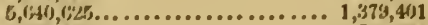

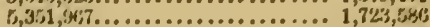

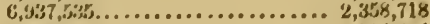

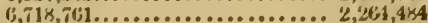

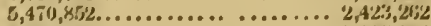

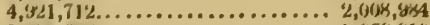

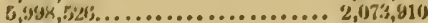

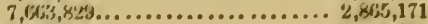

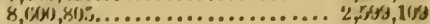

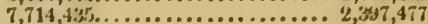

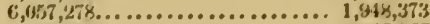

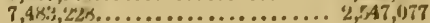

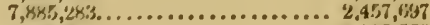

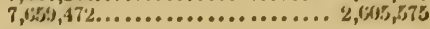

Total

$.10,438,9 i^{2}$.

$\overline{3 t ; 313,120}$

\section{Chicago, Ill.}

Largest recolpts in one llity, fel, 11, 1845, .........

Jargent recelpts in one wersk, ending Nov, 20),

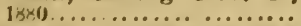

Latrgest recelpts in one munth, Niv., $1 \& 80 . \ldots \ldots \ldots 1,111,937$

darkest recelpte lis ono year, 1801

\begin{tabular}{|c|c|c|}
\hline & Kansas City, Kus. & \\
\hline 74,861 & 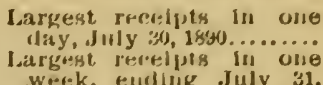 & 26,408 \\
\hline $3100,4 \times 8$ & 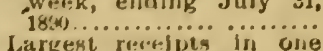 & 165,041 \\
\hline & 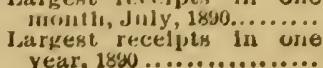 & $34,41 / d$ \\
\hline
\end{tabular}




\section{WHEN TO EXPECT THE PIGS.}

The period of a sow's gestation being, as a rule, sixteen weeks, the following table is presented as showing exactly when sixteen weeks expires from any day in the year that she may be bred:

\begin{tabular}{|c|c|c|c|c|c|c|c|c|c|c|c|c|c|c|}
\hline 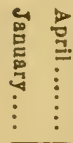 & 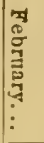 & $\begin{array}{l}\text { 岕 } \\
\vdots \\
\vdots \\
\vdots\end{array}$ & 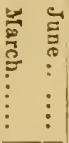 & \begin{tabular}{cc}
$\vdots$ & \multicolumn{1}{c}{} \\
$\vdots$ & $\vdots$ \\
$\vdots$ & $\vdots$ \\
$\vdots$ & $\vdots$
\end{tabular} & 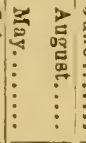 & 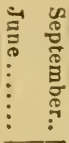 & 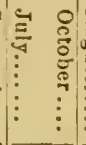 & 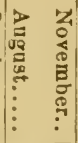 & $\left\{\begin{array}{l}\infty \\
\frac{1}{2} \\
0 \\
3 \\
0 \\
0 \\
0 \\
0\end{array}\right.$ & 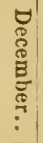 & 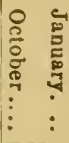 & 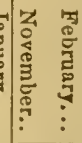 & $\begin{array}{l}\theta \\
0 \\
0 \\
0 \\
3 \\
3 \\
0 \\
0 \\
\vdots \\
\vdots\end{array}$ & 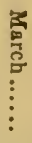 \\
\hline $2: 2$ & & .3 & 1...20 & $1 . .21$ & $1 . .20$ & 120 & .20 & .20 & & .21 & 120 & 1. .20 & & .92 \\
\hline & & .24 & a) 1 & & $2 . .21$ & 2...21 & & & & & & & & \\
\hline $3 . .24$ & & .25 & $3 . .22$ & $3 . .23$ & $3 . .22$ & $3 . .22$ & .22 & $3 . .23$ & & .23 & $3 . .22$ & $=3.22$ & & .24 \\
\hline & & 26 & $4 . .23$ & $4 . .24$ & $4 \times 3$ & & $2: 3$ & $4 \ldots \geqslant 3$ & & .24 & $4 . .28$ & $3+\ldots 23$ & & \\
\hline 52 it & & .27 & $5 . .24$ & $5 . .25$ & $5 . .24$ & $5 . .21$ & $5 . .24$ & $5 . .24$ & & .25 & 5..24 & $45 \ldots 24$ & & \\
\hline 6...27 & & .28 & 6...25 & 6..226 & $6 . .2 .5$ & (i...25 & $6 . .25$ & 6. . 25 & & .26 & 6...25 & $5 \mid 6 . .25$ & & \\
\hline $7 . .28$ & & .29 & $7 . .26$ & $7 . .27$ & $7 . .26$ & $7 . .26$ & $7 . .26$ & $7 . .26$ & & & 7...26 & 6 $\tau . .26$ & & .28 \\
\hline ..24 & 8.. & .30 & $8 . .27$ & $8 . .28$ & 8..27 & $8 . .27$ & $8 . .27$ & $8 . .27$ & & $.2 \mathrm{~s}$ & 3..27 & $78 . .27$ & & \\
\hline 9...30 & 9. & .31 & 9.28 & $9 . .99$ & 9.28 & $9 . .2 \mathrm{~s}^{3}$ & $9 . .28$ & 9..2s & 9. & . 29 & $9 . .28$ & $89 . .28$ & & .3 \\
\hline May & $\mathrm{Ju}$ & ine & $10 . .29$ & $10 . .30$ & $10 . .291$ & $10 . .29$ & $10 . .20$ & $10 . .29$ & 10. & .30 & $10 . .29$ & Mlar. & 10. & \\
\hline 0.1 & 10. & & $11 . .30$ & $11 . .31$ & $11 \ldots 301$ & $11 . .30$ & & $11 \ldots 30$ & 11 . & .31 & $11 \ldots 30$ & 10.. 1 & & \\
\hline 1. & 11. & & July & Aug. & $12 . .31$ & Oet. & $12 . .31$ & & & an. & $12 . . .31$ & & 11 & \\
\hline . & $12 .$. & & & $12 . .1$ & & $12 . .1$ & No & 12. & 112. & & Fet & & $1:$ & \\
\hline & $13 .$. & & 2 & 13. & $13 . .11$ & 13. & 13 & $13 .$. & 213. & & $13 . .1$ & 13 & 13. & \\
\hline 4. & 14. & & & 14. & 14. & & & 14. & 31 & & & & 4 & \\
\hline & & & & & & & & 15. & & & & & & \\
\hline & 16 & & 6. & 16 & 1ii. & 16 & 16 & 16. & 1 & & 16 & & 16 & \\
\hline & & & & & 17. & & & 6 & & & & & & \\
\hline & 0 & & 10 & & 15 & & 18 & 13. & & & & & & \\
\hline & 19 & & & & & & & & & & & & & \\
\hline & 20 & & 20 & & & & & & & & & 11 & & \\
\hline & 21 & & & & & & & & & & & .12 & & \\
\hline & 22 & & & & $100^{\circ}$ & & & & & & 10 & & & \\
\hline & 23 & & & & 9 & & & & & & & & & \\
\hline & & & & & & & & & & & & & & \\
\hline & & & & & & 4 & & & & & & & & \\
\hline & 26 & & & & & & & & & & & & & \\
\hline & 27 & & & & & & & & & & & & & \\
\hline & & & & & & & & & & & & & & \\
\hline & 29. & & & & & & & & & & & & & \\
\hline 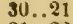 & & & 30 & & $30 \ldots 1$ & & 90 & & & & & & & \\
\hline .2 & & & ? & & 131 & & 31. & & & & & & & \\
\hline
\end{tabular}




\section{DISEASES OF SWINE.}

PRACTICAL INFORMATION AS TO THEIR CAUSEA, SYMPTOMS, PREVENTION, AND CURE. 



\section{CHAPTER XXIII.}

\section{DISEASES OF SWINE AND THEIR TREATMENT.}

\section{INTRODUCTORY.}

We desire to preface this portion of our volume by saying that we are not a hog doctor, and have but little faith in sick hogs, or in giving them medicines.

A sick hog is, as a rule, very poor property, and he who permits this class of stock to become diseased through negligence or mistreatment, under the impression that " anybody knows enough to doctor a hog," is boldly courting disaster.

The hog has an appetite beyond his powers of digestion; if he is allowed to gorge himself on unsuitable fonds, is made to live in filth and mire, from first to last, and is also exposed to burning sun and biting frosts, it can be but small wonder if he becomes the prey of disease.

Prevention, by rational, decent treatment, should be the watch-word; but, if an animal appears ailing, note carefully all the symptoms.

Physicians say that the internal organs of a hog are located much as are those of a man, and that in a majority of cases it will be safe to treat a sick hog, so far as practicable, in the same manner as a sick man should be treated. Medicines ought never to be given without well defined ideas as to what they are expected to accomplish -remembering that "the catalogue of medicine furnishes few, if any specifics, that is, medicines that will always cure certain diseases."

There are, however, a great number of medicines that appear to be specifics for certain symptoms.

The only really successful way of administering medicine to hogs is, to mix it in their feed or drink, as they 


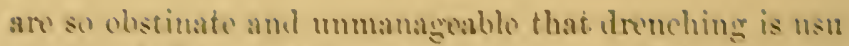

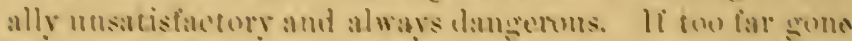

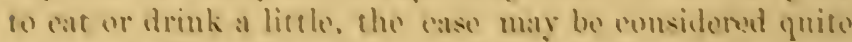
huphess. 'They shomlel he mate as comfortalile as possible. smet it eley will est, wive them fond that is light.

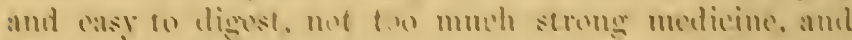

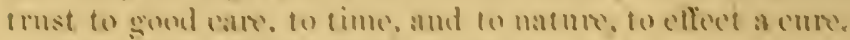

"The relorin lihmer kilhlwill s:lys:

"In winter. I wouhl separate the sick from the henl: give them

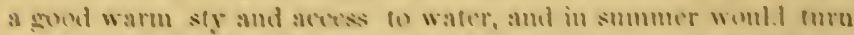
them where they wonht have water for hoth drinking smb bathins,

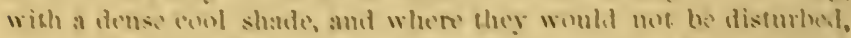

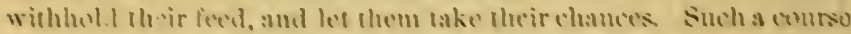

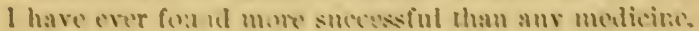

"Prevention is beteer than ens: for a hent of swine property

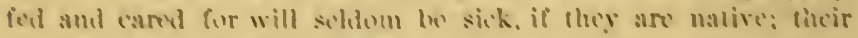

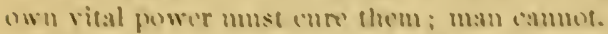

"If they have hiven improperly fed, mutil disense has heen derel.

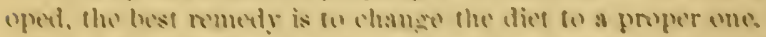

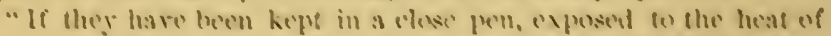
summer, turn them infos tresh pasture where they esm have water, exireiso, amd shiste.

"If they have been kept in a dirty. mudhy pen until they havo semrl ani manse, cle m the skim, and sive them a clesm, comfort-

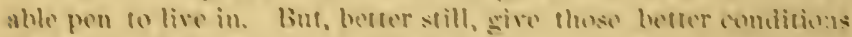
before the ditlieuly arens. Can for them in strance, buth as a mateer of elufy and profit. Int as in morals, the path of duty is the path of happines ame safery, so in the treatment of our demes-

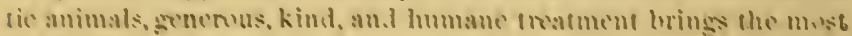
mune?."

Nothing is more natural than that hhose who have capie fal invested in swine shomld, if disc:sse sppesss, desio to

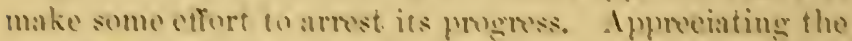

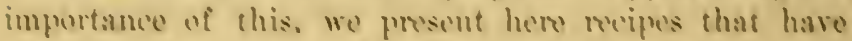

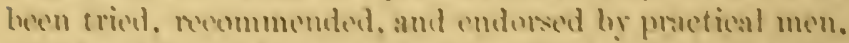
who have fomml them ralushle: and we beliowe them to be more nesty alapted to the wants of swime-breders than any collecrion heretofure maide.

'Hhey aso not recommented as infallible, and wo womld 
again impress it upon our realers and fellow-breeders, that the treatment of cliseasel swine is very uncertain in its results, for when it is so often. impossible to ascertain the precise eharacter or location of the ailment, it is indeed dithicult to preseribe and administer oflicacious remelics. Itenee the " onnce of prevention " is all-imprortant.

The information griven of the disease or diseases known as Hog Cholera, is unquestionably the best and most thorough that tho ablest scientific anthorities in tho country have as yot arrived at.

\section{ANTIIRAX* DISEASES IN SWINE.}

The obseure diseases in swine generally-but quite improperly-desiguated by farmers as "Hog Cholera," have created such fearful ravages in the principal hograising districts as to prove the main obstacle to profitable pork production.

'I'here has been witnessed ammally, for a generation past, the loss, hy epidemic diseases, of millions of dollars worth of swine in this comtry, at a time of year when they were of maximum value.

It is to be regretted that a scourge so prevalent, carrying disister and funancial ruin to such mumbers of our people, has not been made the subject of thorough scientific investigation by a commission, composed of men eminent for their scientific and practical knowledge.

We believe a portion of the appropriation to our $\mathrm{Na}-$ tional Bureau of Agriculturo could. and should, have been used, years ago, to assist in researches to wrest from nature the secret causes of the wille-spread destruction, which, in such numerous instances, makes hog-luising, as a business, so precarions.

If the actire pursuit of knowleige so valuable as this does not cone within the provines of the D'partment of Agriculture, of State Agricultural Boards and Societics,

- Anthrax is the Greek word for carbunclo, or virulent uleeg 
and the richly endowed and richly officered Agricultural Colleges, organized ostensibly in the interests of the producing classes, by whom they are largely maintained, we have failed to comprehend their mission, or importance. While such ruinous devastation is abroad in the land, and millions of dollars worth of swine sometimes die in a single month from diseases scarcely understood at all, it is small comfort to the tax-ridden Western farmers to read, in its voluminous, reports, that the Department of Agriculture is engaged in investigating the Cranberry-rot in New Jersey, or the Orange-blight in Florida, or that the ILassuhnsetts Agricultural College is making elaborate experiments to test the lifting powers of a Squash, which has, at considerable expense, been properly harnessed for that purpose.

No investigation that does not extend through several Stat ss, and include thousands of cases, as found under varying and widely different circumstances, and is not made with a liberal and faithfully continued expenditure of time, labor, and some money, can be satisfactory. The necessary expense precludes private investigations from being sufficiently extended, and if properly conducted, the results obtained would be of such general interest that the General Goverument should lead in the undertaking and bear the expense. Managing our own hogs, on the theory that the "ounce of prevention" was of paramount importance, we have never lost even a single animal by any disease we could call cholera, and as it comprehends conditions and causes regarding which the most learned scientists are as yet groping in comparative darkness, we shall not weary the reader with mere surmises of our own.

Fortunately some two or three of the leading veterinarians in the country have devoted much attention to it, and while none of them claim to have at all solved the mystery in which epidemic diseases are enshrouded, we 
are able to present, in this and the succeeding chapters, the latest conclusions to which their labors have brought them.

From our standpoint, we consider "hog cholera" as caused by a putrid poison in the blood, induced by unwhole some foods, drink, and surroundings productive of disease, essentially a contagious fever, of which inflammation of the lungs, diarrhoea, vomiting, abscesses, and similar features, are simply complications. Law, and others, do not hesitate to pronounce it as having been known in the Old World, as well as this country, and all authorities encountered by us agree that the unwholesome conditions of life contribute largely to its difiusion, if not its development anew.

Every farmer should realize the necessity of prevention, and grasp the fact that the great "cure-all" will nover be found, and that trusting to any remedies, specifics, or patent nostrums, is more than likely to result in a disastrous failure, to arert which too much care cannot be taken in securing the best sanitary conditions of life for this class of domestic animals.

Dr. H. J. Detmers, a distinguished retorinarian; who has devoted much research to diseases peculiar to swine in the Mississippi Valley, prepared for and published in the Rural World, (St. Louis, April, 18\%6, ) an extended article on Anthrax Diseases in Swine, of which the following is a synopsis :

"Although I have had considerable experience, not only when practising as veterinary surgeon in Europe, but also cluring the seven years which I have resided in the State of Illinois, I write with some reluctance, because I know that a good deal of what I shall have to say will conflict with some long-cherished notions and prejudices of a great many readers. In the first place, I wish to banish the name of

\section{'HOG CHOLERA,'}

which is ill-chosen, entirely without meaning, and leads to confusion, as it naturally conveys the impression that the disease, or dis. 
eases so named, are similar to, or identical with the Asiatic cholura, or cholera of men, which is not the case. In fact, what our farmers and swine-breeders are used to call 'hog cholera,' is not a single or separate disease, but rather a group of several kindred diseases, similar to each other in regald to causes, morbid process, contagiousuess, and final termination, but differing very much as to symptoms, seat of morbid process, course, and duration. Hence, the proper name,

\section{ANTHRAX DISELSES,}

which is understood everywhere, is much preferable to the misnomer 'hog cholera.'

"All anthrax diseases-and those of swine not excepted-make their appearance usually as enzootic diseases. They spread over large districts, and attack a large number of animals of the same kind, and in some cases of different kinds, at once, or in quick succession. Only in comparatively rare cases, one or the other form of anthrax presents itself as a sporadic disease-that is, attacks only a few animals, or remains limited to a farm, a pasture, or a stable, or a yard. This, however, is but natural : in the first place, the presence of the pernicious agencies or influences which constitute the causes is seldom limited to a farm, a pasture, a stable, or a yard, but extends usually over whole districts; and secondly, all anthrax diseases develnp a more or less intense contagion, able to communicate the morbid process to other healthy animals, which have not been exposed to the causes, and in severe cases even to men. The morbid process in all antbrax diseases consists in a peculiar decomposition of the blood and of the animal tissues; consequently, everything that is able to introduce or to promote such a decomposition must be considered as a mediate cause.

\section{"CAUSES.}

"The causes of the anthrax diseases of swine are essentially the same as those of the anthrax diseases of other domesticated animals. The same proceed, to a great extent, from certain peculiarities of the soil and of the weather, and have their source also-partially at least-in the mode and manner in which the animals are kept. It is possible, accorling to the scientific investigations and experiments which have been carried on with great zeal during the last decade, that various cryptogamic parasites, the bacterii, vibriones, and others, found in the blood and in other fluids of anthrax patients, act either directly or indirectly like a ferment upon the blood, effect a decomposition of that fluid, act in that way as a 
causal agency, or a cause, of the morbid process and its usually fatal termination.

"The experience of our present age, as well as the earliest ibservations on record, show that anthrax diseases are apt to occur wherever large quantities of stagnant water, surcharged with decomposing vegetable substances, are evaporating. Hence, anthrax diseases may be expected on naturally wet or low land, in a dry season, and on naturally high and dry land, provided the soil is rich in humus, in very wet seasons. The various forms of anthrax, therefore, make their appearance especially as epizootic, or rather enzootic, diseases, in all localities or districts in which the top soil is rich in humus and decomposing regetable matter, and the subsoil impervious to water, at the end of a wet season, or after an inundation; and in localities or distrlcts in which swamps, sloughs, and pools of stagnant water are numerous and extensive during a hot and dry season, particularly if the animals are compelled to drink foul or stagnant water containing a considerable quantity of decomposing vegetable substances. The water of ponds in which flax has been rotted, must be regarded as extremely dangerous, for this reason.

"Pastures and stubble fields, rich in sulphates, or manured with mineral fertilizers, which effect a more rapid decomposition of the vegetable substances, are also more dangerous than others.

"The weather, too, is not altogether without influence. Weather that is too hot and too sultry for the season of the year, or that is very changeable, (for instance, very warm during the day, and cold at night), seems to promote the outhreak of anthrax diseases. The climate, or the average temperature of a country, is without any consequence, for anthrax makes its appearance as well in the polar regions as in the temperate and in the torrid zones.

"As to the keeping of the animals, it has been observed that sties or pens, full of dung and rotting vegetable substances-clover, weeds, ctc.-especially if the latter are wet and exposed to the rays of the sun, have a decidedly bail influence, and are able to act as a cause. Further, certain kinds of food, that contain an abundance of nitrogenous compounds, and are difficult to digest, or very juicy, and of rank and rapid growth, have a great tendency to pro.mote the development of anthrax diseases. As such kinds of fool -though some of them are scarcely ever fed to swine-may be named: aftermath clover, the grasses and weeds grown on stubble gelds in a wet and warm season, green rye, and green wheat, distillers' mash, moldy hay, spoiled or moldy garden vegetables, 
musty and moldy grain, and especially grain that coutains a great deal of smut. It has been stated time and again, that grasses grown on places or spots where animals diseased with anthrax had died, or hiad been buried, are able to produce anthrax in living animals. Whether this is true or not, I am unable to decide; I give the statement for what it is worth. Still, it seems that scarcely any one of these more or less injurious kinds of food is able to produce anthrax by itself, but, if acting combined with the influences of evaporating stagnant water, surcharged with decomposing vegetable substances, the same may become very pernicions.

"A great anl dangerous predisposition to anthrax diseases is originated, also, by a sudden increase of very nutritious food, causing a rapid improvement of the condition of the animal from poor to good, or from middling good to very good, by accelerating and augmenting rather excessively the organic change of material, or process of wasting and repairing, that is constantly going on in every living organism. If the change of matter is increased too suddenly, or to such an extent that the organs (lymphatics, kiclneys, skin, intestiues, etc.,) which have the office of disposing of the waste material, and excreting the same, but have been accustomed to only an ordinary quantity of water, cannot absorb and carry off the extraordinary amount that is produced, in consequence of the rapidly-promoted change of matter-a quantity of wasted material, consisting of nitrogenous (urea, for instance,) and carbonaceous compounds, will be retained, and will accumulate in the system, but especially in the blood, where they are apt to become a source of decomposition.

"The predisposing influence of a very rapid growth and im provement in condition, explains why, in every anthrax epizooty, or enzooty, just the most thrifty and fastest improving animals become the victims, and contract, almost invariably, the disease in its most acute and most malignant forms; while the poorest aninals in a herl remain either exempted, or take the disease in a less acute, or comparatively mild form. Age ancl sex seem to be without influence.

\section{"TIIE CONTAGION.}

" A very important source of the spreading of the disease constitutes the contagion. The same is of a fixed, rather than of a volatile nature, and all parts of the animal body (but especially the blood and the fluid products of the morkid process), must be looked upon as its bearers. The vitality of the contagion, and the resistance of the same against external infuences, is very great; it 
is not easily destroyed by exposure to the air, to warmth, cold, moisture, etc. Its intensity, however, is not always the same, but differs according to the form and malignancy of the disease, and the genus of the animal; for it has been repeatedly observed, that contagion in neat cattle, is usually more effective than that developed in horses, or in hogs. It is destroyed most effectually by chemical agencies - for instance, by carbolic acid, chloride of lime, etc.

"The fact that carbolic acid, a most deadly poison to all parasite growth, (vegetable, as well as animal,) destroys also, quicker and more thoroughly than anything else, the efficiency of the contagion developed in anthrax, and in other contagious diseases, may be looked upon as a strong support of the theory which assigns to the cryptogamic parasites, found in the blood and in several other fluids of patients diseased with authrax, or with any other contagious diseases, a close connection with the contagion.

"The period of incubation (that is, the time which elapses between the exposure to the influence of the contagion and the outbreak of the disease rcsuiting from it), is not always the same, but extends from a few liours to about two weeks. The form of the disease resulting from a contagious infection, is not always identical with the form of anthrax which produced the contagion, but depends upon the seat of the morbicl process; and the latter usually localizes itself in the same parts of the body which have been the principal recipients of the contagion.

"Anthrax in swine, as well as in all other domesticated animals, makes its appearince in different forms, which may be divided into two groups-one without any localization of the morbid process, and another one, in which a localization is taking place. The forms belonging to the first group, are characterized by their extremely ace te course, and great malignancy. The morbid process affects the whole or ranism, and has no time to localize itself, ba: destroys life usually within a few hours, and ia some cases even within a few minutes. The forms of anthrax belonging to the second group, are less acute in their course; they last from several hours to several days, and the morbid process, too, is less violent, and has time to effect a localization in one or another part or orgat of the animal's body.

\section{"GA NGRENOUS ERYSIPELAS.}

"Gangrenous, malignant, or contagious erysipelas-St. Anthony's fire, or Wild-fire-must be considered as the most frequent anthrax disease of swinc. Its outbreak is usually preceded by some 
more or less plainly developed precursory symptoms, which, howcvir, often remain unohserved. The animal, a short time before the evident outbreak of the disease, appears to be dull and weak, refuses it: food, has an unsteady gait, lies down a great de'al, roots in its beclding, and shows a tendeney to bury its hend (or, if the litter is abundaut, its whole boty), in the straw. The temperature of the body is changeable, cold shiverings and feverish heat alternate with each other in quick succession ; pulse and respiration are accelerated; the bowels are constipated, or the exerements that are voided are hard and dark-colored; in some cases, the patients make ellorts to vomit. In about twelve or twenty-four hours, the symptoms become more characteristic. Rel spots, which soon become contluent, make their appearance on the inside of the legs, on the lower part of the abdomen, on the breast, and neck, and soon present an (rysipelatous swelling of (at first) a blood-red or crimson, afterwards a purple, and finaliy (if the termination is to be fatal) a bluish-black color. In some cases, small pustules, with gangrenous, corrosive contents, make their appenrance on some parts of the swelled surface; the lever increases in intensity; the mucous membranes present a purple, or lead-gray color; the breathing beconcs very laborious; the temperature of the body, at first considerably increased, is much reduced; the hind quarters of the animal berome paralyzed, convulsious set in, and the sick animal dies, sometimes within six or twelve homrs, but usually on the second or thind day after the outbreak of the disease. In those cuses in which the animal reovers, the red spots either remain limited, or become less contluent; the fever does not reach so high a degree of intensity, and the other morbid conditious abate, if not before, on the second or third day. Still, some morbid changes, such as partial paralysis in the hind quarters, insutlieient appetite (the animals frequently camot be induced to ent any more than the least amount necessary to keep them alive), defective digestion, etc., often remain, and the recovery is sclutom a perfect one.

"Tle treatment has to be essentially the same as in gungrenous angina. At irst an etiective emetic, and afterwaris calomel, or sulphate of sodin, and if the latter is chosen, diluted acids, espercially diluted earholic acid (one part of the erystallized acid to two parts of glycerine, or alcohol, and one hundred parts of water), to be given with extreme care, with a spoon, and in repeated doses, often have a farorable result, provicled the treatment is begun before the morbid process has made too much progress. Externally, subeutaneous injections into the swelled parts, of diluted 
carbulic acid ( $2 \frac{1}{2}$ or 3 parts to 100 of water), have also proved to be of some benefit, and may at least counteract, to a great extent, the septic process.

\section{"MALIGNANT OR GANGRENOUS ANGINA.}

"Malignant, or gangrenous, angina is one of the most frequent forms of anthrax, at any rate, more frequent in swine than either apoplectic or gloss anthrax. It usually presents itself as an enzooty, and is therefore often complicated with other forms, especially with malignant erysipelas, so-called St. Authony's fire, or Wild fire. The morbid process has its principal seat in the throat, in the mucous membranes of the laryn $x$ and of the windpipe, and in adjoining parts, but is, in some cases rather concentrated in, or limited to, a certain part-the larynx, for instance-and in other cases more diffused. Consequently, some patients present more outside swelling, or show greater distress and difliculty of breathing than others, although the disease is the same.

"The principal symptoms, though not all of them are alike conspicuous in every patient, consist in wheezing and laborious breathing, hoarse grunting, great heat, and dryness of the snout, swelling of the tongue, a brown-red color of the mucous membranes of the molith, difficulty in swallowing the food, and attempts to vomit. In the laryux region, and along the windpipe, appears a hot, hard, and painful swelling, which not seldom extends down ward and backward to the forelegs, or even to the lower surface of the chest and atslomen. The swelled parts present, at first, a saturated red or crimson, afterwards, often, a reddish lead-gray, and finally a purple color, and an œdenatous character. The fever is usually very high; the sick animals breathe with increasing difficulty, and either lie down, or sit on their haunches, like a dog. Finally, the difficulty of breathing becomes so great, that desperate attempts have to be made to catch a little air by opening the mouth, and protruding the livil-colored and swelled tongue. The mucous membrane of the mouth, at first red-brown, clianges its color to lead-gray; the temperature of the body, at first considerably higher th:n in a liealthy animul, decreases below the normal degree, and the patients rither die of suffocation, or in consequence of the spreading gangrene, within one or two days. In those cases in which the morbid process has concentrated itself in the luryax, the patients suffocate a great deal sooner, and die, sometimes, within an hour after the appearance of the morbid symptoms.

"If the disease does not terminate in death, which is but seldom 
the case, unless the patients are subjected to a rational treatment during the very tirst stages of the disease, the morbid symptoms are gratually rednced. In such a case, the respiration hecones freer and less laborious; the wheezing disippears; the difliculty in swallowing food and water abates, and the exterual swelling ceases to sprual, and finally decreases gradually in size. Malign.tut angina, as well as other forms of authrax, has either an idioyathie origin, or is the consequence of an infection hrought about, in most ease's, by eating meat, blood, ctc., of animals that have died of anthr:ts.

"A treatment, to be of any avail, must be instituted during the very first stages of the disease. It is best to commenes by giving a good emotic, consisting of two to twenty grains (according to the age and size of the patient) of powdered IV hite Hellebore (Feretrum (album), or of 'Tart:or Emetic. The former, however, is more reliable, and therefore to be preferred. Both medicines must be given, either with a little milk-if the patient will take them voluntarily-or, mixed with a pinch of flour and a little water, or a piece of boilcd potato, in form of pills-if force is nccessitry, but under no circumstances in the shape of a drench. If the animal should not vomit freely within twenty minutes, the dose has to be repeated. Afterwards, the so-called antiphlogistic salts-sulphate of soda, sulphate of potas!ı, sulphate of magnesia, saltpetre, or ealomel, maly be given to some alvintage. Diluted acids, vegetable as well as minerul, lut especially thluted carbolic acid (1 to 100 of water), and sibcutaneous injeetions of diluted carbolic acid (21) or 3 parts of the acid, 5 parts of glyeerine, an. 95 parts of water), made into the swelled parts at virious places, have been used to advan. fage, and hove given, in many cases, at least, much better satisfactio.s tian anything else. Some anthors have advised to draw setons or rowels, to tix the swelled parts with a red-hot iron, or to apply coll water clouches, but if the nature of ihe lisease is taken into consideration, it is diflieult to see what good sueh remedies c:un do. Blood-letting, too, lias been recommended, but if resorted to, it must be done during the very first, or incipient, stage of the disease, otherwise it will only aecelerate the fatal termination.

"As preventive remedies, diluted acid, sour buttermilk, unripe sour apples, ouce a week a dose of sulphate of soda, and especially, now and then, a little carbolic acid in the water for clrinking, have proved of some value.

\section{"AYTHRAX CABBSNCLE, OR WHTTE BHISTLE.}

"Real anthrax carbuncle is of comparatively rare uccurrence in Logs. Its outbreak is ulways attended with very severe fever, and 
the carbunculous swelling usually makes its appearance on the neck, in close proximity to the larynx, and is extremely painful. 'The bristles, or hatir, on such a carbuncle, become bleachel, hard, and brittle, and stind on end, therefore the name "white bristle." Finally, great difticulty of breathing, grouning, gnashing and grat. ing of the teeth, and convulsions, constitute the last symptoms and the precursors of death, which ensues usually within a l'ew days.

"The local treatment consists in destroying, or cauterizing, the carbuncles as soon as possible, by means of a red-hot iron, or with a concentrated aeicl. The general treatment has to be the same as iu malignant angina.

\section{"AYOPLECTIC ANTHRAX.}

"The apoplectic form of anthrax, the most acute of all, is not so frequent in hogs as in cattle and shecp, but wherever it occurs, it usually terminates within so short a time, that the owner of the smitten animals will either find them dead, or will just come in time to see them break down and die, before he even suspected them of being sick. Death is almost instantaneous, and treatment, therefore, is out of the questivil. Some twelve or fourteen year's ago, one of my own pigs, a nice, thrifty animal of common stock, died of this form of anthrax. It stepped back from the trough, turned around, squetled, tumblei down, and dicd in less than half a minute. In some-though still rarcr-cases the termination is not quite so rapid; the discased animals manifest sickness, by showing symptoms of distress; their gait becomes unsteady and swaggcring; the visible mucous membranes appear very much reddened; the temperature of the body changes from feverish heat to cold shiverings, which follow each other in rapid succession. After this stage, the sick animals frequently vomit a bloody or discolored fluil, and usually die very soon, under convulsions. In some cases, earlunncles or erysipelatous swellings make their appearance a short time before cleath, indicating a tendency of the morbid process to localize itself.

\section{"THE MOUTH, GUM, OR GLOSS ANTHRAX,}

or mulignant pustule of hogs, is one of the most acute forms of the second group, and a comparatively rarc disease.

" Restlessuess, loss of appetite, a distressful and staring expression of the eyes, abnormal heat in the nucous membranes of the mouth, gnashing the teeth, and slavering, constitute the first morbid symptoms, and the first indications of the presence of disease 
and high fever. Very soon, however, (at any rate within an hour or two), one or more, but schlom miny, pustules, esch the size of

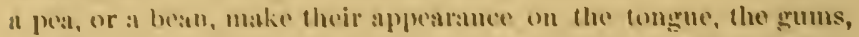
and in other parts ol the momth. 'These pustules, surroumded at theil basc hy an erysipelatous swelling, are tirst yellowish-white, but change their colol very soon to brown, met thally to black,

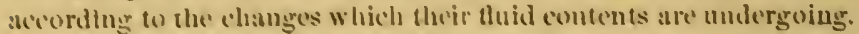
'The fever, at the same time, has beome rerye serere. These pustules, if not enty chomgh removed and destroyed, together with theil contents, will soun break and discharge their gangrenous thid, which will cause mortilkation in every tissue with which it comes in contan. In such a case the animal will die, usually within a few hours, but at any rate within a fow days. As a geveral rule in this, as well as all other forms of athrax, the better the condition of the pationt, the somer loes it terminate in death. The trestment, on newent of the rery aneme eourse, and of the peculiar seat of the discise, is dittleult. The pustules have to be opened, and emptied of their contents, by me:ans of a smatl spoon with somewhat sharp or thin edge's, (one nude of tin will suswer hest), and the romaining sores have to be canterized, with either sulphuric, hydro-(hloric, nitric, ol carbolic acid. The openiag and destroying of the pustules, and the application of the acid, are attendin with some danger to the operator, unless he is very careful not to soil his hamds with the contents of the pustules. A person with sore's on his lommls shumld never molertake it. The whole operation, howerer, is uscless, muless the pustules are npened in a very dexterous mammer, amd their contents removed at once, so as to prevent the animsl from swallowing them. 'The general treatment hats to be the same as that of the foregoing for:us of anthrax.

\section{"PliEvition.}

"As to prereution, really not much remains to he said. Remoring the eauses, smb, as the disense is coutagions, separating the lewithy animbls from the sick omes, and le'stroying the comtagion wherever it exists, by means of ctude carbolic acid or with ehloride of lime-constitute the primeipal and most important messure's of prevention. bisiles this, atre must be taken, wherever it is inconded to improve the condition of au animal, (1) do so gradusllyto feed regularly at all times, and grive uothing but what is healthy and somd. That pure, clesu water tor drinking, is alsolutely

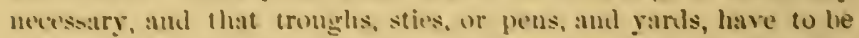
kepe as cle:ul and dry as possible-need to he specially mentioned. In those sections of the country, in which the natural condition of 
the soil is such as to invite a levelopment of anthrax discases, where, in other words, the top soil (e)nsists of a rich lumnus, and the subsoil of in impervious elay, or where sloughs and swamps are extensive and numerous, or where the comintry is subject to innulations-proper Irilining, thorolude cultivation, drying of the swanps and wet places, and luileling dykes or levees, or digging cautals, to provent the inumlations, constitute the only prerentives that e:u be applied. Mledicines, in such ases, are of no avail; they cun be used to advantage only where it hecomes necessary to assist the organism in cjeeting waste material. Hence, tho feeling of eopperas, chareoul, sulphir, snltpetre, salt, ashes, and all the lumired and one other things, that have been recommended, is perfectly useless, if not injurious, and has never prevented a solitary case of anthrax, or so-enlled long cholem. I um sure my own Bcrkshires are as healthy and thrifty unimals as ean be fouml anywhere, mo they never receive anything of that kind; but they nre regulurly fed, hitve good stios, spacious yards, und, what is most importunt, plenty of pure spring water to drink, und to take a bath in, whenever they fecl like it."

\section{CIIP'IER XXIV.}

\section{THF SO-CALLEI) " HOQ CIOLHRA."}

TIF REPOLT OF DK, II. J. DETMERS.

During the year $18 \% 5$, and for the greater part of $18 \% 6$, thero prevailed, in Missomi, a disease among swine, to an alarming extent, which was called by tho farmers " $h \mathrm{hog}$ choler:a." 'The same disease, or one closely resembling it, was exceedingly destructive in Illinois, and other hogprolucing States. The Missouri State Board of Agricnlture, recognizing the fact that a disease must be understoot before proper curative, or even preventive means combl to employed, assigned to 1)r. H. J. Detmers, Professor of Veferinary Science in tho State Agricultural College, the duty of investigating the discase in its vari. 
ous forms and in all its stages. His examinations were made in different parts of the State, on both living and dead animals, and animals with the disease in various degrees of development were killed, to allow of postmortem examinations, careful inspections were made of localities in which the disease was most prevalent, ete. The results of his labors are embodied in a Report to the Board, dated Sept. 8, 18\%6. This Report, with the exception of a few unimportant paragraphs, is here given :

\section{"THE NATURE OF THE DISEASE.}

"The morbid process presents itself in a majority of cases as a cotarrhal rheumatic, and in others as a g:stric rheumatic or billious rheumatic affection, and exhibited always more or less plainly, a decidedly typhoid character. As a catırrhal rheumatic affection it has its principal seat in the mucous membranes of the respiratory passages, in the substance of the lungs, in the pulmonal pleura or serous membrane coating the external surface of the lobes of the lungs, in the cost l pleura or serous lining of the internal surface of the chest, in the diaphragm, and in the pericardium, or serous bag enveloping the heart. As a gastric-rheumatic affection, the principal seat of the disease is found in the abdominal cavity, but especially in the liver, in the spleen or inili, in the large and small intestines, in the kidneys and ureters, and in the peritoneum or serous membrane lining the interior surface of the abdominal cavity, and constituting the sxternal coat of most of the organs situated in that part of the body. Hence, the name Hog Cholera is an ill-chosen one; it tends to convey the idea that the disease in question is similar to, or identical with, the cliolera of men, which is not the case; therefore the application 'hog cholera,' which has already led to a great many mistakes in regirl to treatment and measures of prevention, should be abolished at once, and a more appropriate name should take its place. As such a one I wish to propose 'Epizootic Influenza of Swine,' for two reasons: First, the disease in question bears, in all its morbil features, and especially in the diversity of its forms, produced by the differences in the seat of the morbir process, a strikin's resemblance to the yet wellremembered epizootic influenza of horses, which swept the whole country a few years ago from the Atlantic to the Pacific; second, I admit it might be more convenient to select a name derived from a conspicuous and characteristic symptom, or from an important 
and constant morbid change-pleuro-pneumonia of swine, for instance-if the main seat of the morbid process was always in the respiratory organs, or invariably the same in every patient. But as this is not the case, as the seat of the disease is found not only in the respiratory apparatus, but also, in a large number of cases, in the parts and orgaus connected with the digestive process, and, in some cases, even in the centres of the nerrous system, a name had to be chosen that is comprehensive enough in its meanings to cover all the different forms under which the disease is able to make its appearance, and, at the same time, sufficisntly distinct to prevent any diagnostic confusion. As such a name I cannot think of any that would answer better than that of Epizootic Influenza of Swine, which, therefore, I recommend for a general adoption.

\section{"SYMPTOMS AND MORBID CHANGES.}

"As the morbid process has its seat in various organs or parts of the body, the disease presents itself in different forms, and manifests its presence by different symptoms, so that, at any rate, besides other complitations, two principal, and two subordinate, forms or varieties must be discriminated.

1. The Catarrhal Rheumatic Forms.-This is the most frequent of the two principal forms. The morbid process has its main seat in the respiratory organs; the disease presents the features of a respiratory clisorder, and either the catarrhal or the rheumatic character predominates, or both are equally developed. If the latter is the case, the whole respiratory apparatus may be found diseased. If the catarrhal character is the one that is most developed, the principal seat of the discase will be found in the larynx, in the windpipe, in the bronchial tubes, and, to a larger or smaller extent, in the substance of the lungs; and if the rheumatic form is the predominating one, the principal morbid changes occur in the serous membranes of the chest, (the costal and pulmonal pleura and the pericardium), and also, to some cxtent, in the tissue of the lungs. In most cases, however, the catarrhal and the rheumatic character are blended with each other, and the respiratory pas. sages, the tissue of the lungs, and the serous membranes, or parts of them, are more or less diseased.

"Animals afflicted with the catarrhal rheumatic form indicate the presence of the disease by a short, more or less hoarse, hacking cough-generally one of the first symptoms-by difficulty of breathing, a panting or drawing motion of the flanks at each breath, by holding the head in a peculiar, stretched, and sonewhat drooping position, by a slow and undecided gail, a peculiar hoarse- 
ness when caused to squenl, etc. The attending fever is severe enough to announce its presence hy unmistakahle symptoms, such as accelerated pulsation, changeable temperature, etc. Some of tue sick animals show at the beginning of the disease a tenclency to romit, and have diarrhea, while others are more or less constipated from the first, and remain constipated till the disease is realy to terminate in death. If the catarrbal character is the most prevailing, but especially if the morbid process has developel itself principally in the throit and in the windpipe, more or less swelling (quinsy) will make its appearance.

"At the post mortem examination some important morbid changes will invariably be found in the lungs. l'ortions of the same thare become impervious to air by being gorged with exudation. The diseased tissue hits lost its spongy feature, has beeome heavier, and more soliul, similar in appearance and consistency to a piece of lirer -a condition called hepatization. In some cases the diseasel or hepatized parts of the lungs present a uniform red or reddish-brown color, and indicate that the exudation has heen produced, and been depositel in the tissue of all the diseased lobules, at the same time, or without intermption. In other eases, the single lobules in the disused portions of the lungs present different colors; some are red, some brown, and others gray or yellowish-gray, which gives the whole hepatized part a somewhat marbled appearance, and shows that tho exudation has been produced and been deposited at different periods. The gray hepatization, which is the oldest, and the brown, which comes next in age, contuin frequently a few tubereles, or eren here and there a subll nker interspersel. Otherwise neither uleeration nor suppuration has ben obserred. Important morhid changes are usually found also in the serous membranes of the tholax. The same consist in a more or less firm coalescence between parts of the pulmonal plenra and the corresponding parts of the costal plenura, and in an accmulation of a larger or ainaller quantity of straw-colorel water or sermu in the chest. In other eases, those in w!ich the rheumatic character has been predominnting, the morbil produets of the disensed serons membranes are frequently very copious; t'se adhesion between the pulmonal and custal pleurn, or between the external surface of the lungs amb the internal surface of the witls of the thorax, is usually very extensive; mul in some cisses purts of the posterior surfue of one or both lumgs are fomml firmly united with the correspunling parts of the diaphragm or memhrimeus partition which separates the elest from the ablominal avity. The qumntity of serous exuilation, or straw-colored water depusited in tho chest is often 
very large, and the pericardium, too, contains in most cases a larger or smuller qumuty, sometimes enough to interfere serionsly with the functions of the heart, and to constitute therehy the imme. diate canse of denth. The bloot is found to ho thin and watery in crery ease, and coagulates lapidly to n uniform, hut somewhat pale-red clot and of loose texture. It i quantity is always very smull.

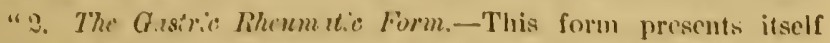
mot equite so often as the catarhat rhomatic, hut is fully as malignut, and constitutes the sccond main form which the disense is founci to assume. The morbid process has its principal seat, and produces the most important morthid changes, in some of the orgams eituated in the alkdominal eavity, but especially in the liver, in the splecn or milt, in the kidneys, the ureters, in the intestines or guts, and alnost invariahly in the peritunemm or serous mem. brane, which lines the interior surface of the uhdominal earity, and constitutes tho external coat of nearly erery intestine.

"Tho symptoms which present themselves while tho mnimal is iving, ditlier not very essentialy from those olserved in the caturthal rhematic form. The short, lancking eough, enarneteristic of the latter, is more or less wanting: Il:e ditticulty of brenthing is less plain; the weakness in the hind quarters, and the staggering or unstendy gait, ohserved only in limited degrees in the eatarrhal rhemmatic form, is moro conspicuous, and the forer is fully as high in one form as in the other.

"In severe enses, the attected amimals areh their backs, or rather the lumbal portion of the same to a very light degree, so that the ottline of the back resembles somewlat the shape of un on. I ohserved this especially in those eases in which the morbicl process has established itsell in the kilneys and in tho ureters, and in which a large quantity of serous cxudation, or straw-eolored water, laul accumulated in the abdominat carity.

"Animals atlected with the gastrie form, show usually more or less costiveness of the howels. The dum is of the consistency of shocmaker's wax, and is rolded in small, irregular-shaped lalls, which are usually coatel with a layer of grayish or discolored mucus. Still, if the disense is neur its futal tormination, the constipation, in many cases, gires way to a profuse and fetid diarrhoa, which may be looked unon, in every instance, as a very fatal sign, and a forcrunner of death.

"The principal morbid ehamges, us I have found them, are as follows: 1. Degeneration of the liver, lirought about by a copious exudation infiltrated into the tissuo of that organ. Such a degen- 
eration, although not a constant morbid change, is found quite often. In some, not very frequent cases, a few tubercles, and in others, still less frequent, even a few very small abscesses, have been found imbedded in the diseased sabstance of the liver. 2 . Morbid enlargement of the spleen or milt. I found this change in nearly every case. In sume cases, the enlargement was not very conspicuous, but in others the spleen was more than three times its natural size, was perfectly gorged with blood, presented a dark black-brown color, and was so soft that very slight pressure with a finger was sufficient to sever its tissue. 3. In quite a large num. ber of them I found one or both kidneys diseased, enlarged, and presenting an inflamed appearance. In one case, both kidneys and both ureters exhibited a high degree of inflammation, and considerable gangrnnous destruction. The latter, however, was probably not a consequence of the disease; the animal had been drenched repeatedly with oil of turpentine, and was the only one in which I found any gangrene. In another animal, which, by the way, was already couvalescent, and was killed by bleeding, I found one kiclney enlarged to three times its natural size, its pelvis very much distended, and its funnel-shaped ureter clilated to such an extent, where it proceeds from the kidney, as to present a diameter nearly one inch and a half. The walls of the ureter were very thick and callous, especially at the anterior, funnel-shaped end, and the latter contained in its interior a semi-solid, fibrous substance, which occupied the whole cavity, and extended even into the kidney. 4. In some cases, I found the membranes of the intestines, or guts, but especially those of the jejunum or small intestine, of the cœecum. and colon, or larger intestines, and also the rectum, in a more or less inflamed and degenerated condition. In tro cases, a whole convolution of the jejunum had united to an almost solid bunch. On opening the latter, I found, in each case, all three membranes, but particularly the external or serous membrane, and the internal or mucous membrane, very much swelled and degenerated, the passage nearly closed, and in a small cavity in the centre of the bunch, one or two large round worms (Echinorhynchus gigas) imbedded. In another case I found, besides other morbid changes, a few round worms in the stomach, and in the mucous membrane of the guts or intestines, a large number of callous scars, such as are usually left behind where the gigantic Echinorhynchus, or hookheaded worm, had been fastening itsolf. These three cases just mentioned, are the only ones in which I have found any entozoa, or worms, in the digestive canal. 5. In almost every case, I found larger or smaller portions of the peritoneum or serolis membrane 
which lines the inner surface of the walls of the abdominal cavity, and the exterual surface of nearly every intestine, swelled and more or less inflamed, and inobility changed. In some cases, even a coalescerce between parts of the intestines, especially the jejunum and rectum, and the walls of the abdominal cavity had been effected; in case, a part of the jejunnm had become firmly united to the lower border of the right lobe of the liver, and in another the whole rectum adhered so firmly to the upper wall of the pelvis and of the posterior part of the abdominal cavity that it required the use of a knife to affect a separation. 6. I found in every animal that had been affected with the gastric rheumatic form of the disease, a larger or smaller quantity of the straw-colored water or seruns, and small lumps and flakes of coagulated fibrine in the abdomi.ual cavity; in some cases, the quantity was quite a large onc, and in others the quantity was comparatively small.

"Two cases must beconsidered as subordinate forms, in which either onc of the principal forms-the catarrhal rheumatic and gastric rheumatic-is essentially modified by being complicated with an affection of the brain and its membranes, or with a serious disorder of the lymphatic system. Hence, two subordinate forms have to be addied.

"The perspiration-perceptible and imperceptible perspirationcan be interrupted, or in other words, the skin can be disqualified to perform its functions by several means; for instance, by a disturbance or partial interruption of the circulation of the bloor in its capillary vessels, by congestion, inflammation or degcneration of its tissue, or of a part of its tissue, by a closing of its pores by mechanical means, etc. This granted, it remains to ascertain, if those hogs and pigs mhich have been, or which are yet, affected with the epizostic influenza of swine (erroneonsly hog cholera), have been subjected to one or more of those just named influences, or agencies, able to cause an interruption or partial ressation of the perspiration. Taking these facts just as they have presented themselves, that question must be answered in the affirmativn. My investigations and my inquiries bave convinced me that in ail those logs or pigs which have suffered from, or died of, that disease, one or more of those influences or agencies have been at work, as I shall try to show.

"1. All animals affected with that discase-at any rate, all those which I have seen, and I bave seen a vely large number--mere exceedingly lousy. Lice irritate the skin, keeping it in a semiinflamed condition, cause swelling, and finally a gradual degenera. 
tion of its external layer, and constitute, therefore, beyond a doubt, a cause disturbing to some extent the normal perspiration.

"2. Ail the hogs and pigs which have contracted the disease, have becn exposed, night and day, to all the sudden changes of temprature and weather so frequent in our Westeru States. Some of the animals bave been kept in small, wet, and dirty yards, or inclosures, without a roof to protect them; they had to suffer Inring the clay from the rays of tixe sun, and from the heat which naturally accumulated in a small space, or lot, walled in hy a tight fence, and is constantly increased by the wet manure and other organic substances. During the night, the same animals were exposed to the chilling influcnee of the cold night air, and frequently very heavy dews, not to mention the effects of severe rains and thunder storms. Further, after each heavy rain, the animals thus kept had a chance tu get their whole body covered with mud, and $t: 3$ pores of their skin thoronghly closed, but an opportunity to g.t ril of the mud by taking a bath in clcan water, was never given. Such influences, evidently, are very apt to cause irregularities in the circulation of their blood in the capultiry vessels of the s'in, and, in consequence, an interruption of the pcrspiration. Other anmals have been kept in comparatively large herds, and h.ive been allowed to run at large in the barnyard, in a so-called bog-lot, in the woods, etc. These, too, were exposed more or less to the burning rays of the sun during the day, but during the night, the same, in most cases, found shelter under a corn-crib, under an old stable, or an old barn, or, at any rate, in the closest and dirtiest places, where they lacked room, and where they were often crowded on top of each other when retiring to sleep. As a consequence, the animals bccame heated and perspiring; and took cold and became chilled when they rose in the morning from this common lair. A sudden cooling, lowever, or a sudden reduction of temperature of the surface of the body, is apt to effect a contraction of the capillary ressels of the skin, hence diminished sup. ply of hlood, and, in consequence, a decrease or partial interruption of the functions of the skin. The animals, thus suddenly cooled by the cool morning air and the wet dew, become, in the course of the forenoon, again exposed to the rays of the sun and the heat of the day, which induces them to go into the first pool of water -if one was accessible - to take a bath. This is all right and well enough, because, in the summer, a hog should have access to water, and an opportunity to take a bath as often as it desires. In all those places, however, in which the disease has made its appearance, I have found the water to which the hog had access, almost 
invariably so shallow, and of such a limited quantity, that the hathing and wallowing of one of a few animals was sufticient to convert the same into a sticky, semi-fluid mud. Consequently, if the lierd was a large one, only a few animals-and these invariably the stronger and most active ones-had now and then a chance to find clean water, and to reap real benefit from taking a bath. All others, but especially the younger and snialler animals (shotes), were compelled to wait till the first comers were through with their bathing, and had changed the water to mud ; the former, therefore, had scarcely ever an opportunity to clean themsilves from the mud of the preceling $d i y$, and to open the pores of the skin by taking a bath in cleas water. If they wish to take a little cooling, they have to be sutisied with a mud-bath, and as every new bath is a mud-bath again, tie pores of the skin, as a consequence, instead of being opened, will become closed more and more effectually from day to day, until finally the perspiration wil: bo thoroughly interrupted, an $\mathbf{l}$ the result, clisease, will make its appearance. It is different if the herl is a small one, for then nearly every animal will have, sometimes, a chance fo open tie pores of its skin by a bath in tolerably clean water, and the perspirition will not be seriously interruptel. That these directions must be correct, can be provel by my observations, which show that in almost every large herd, nearly all the younger and weaker anim ils (s'lotes), have become a prey to the disease, while the large and strouger, or most active animals, which are usually the firs: ones to go to the water in the moruing, when the same is yet tolerably clean, and which usually secure at night the best plices in the common lair, have either remained exempt, or have had the diszıse in a milder form, and have mostly recovered. Finally, small herds have either suffered fewer losses, have been less severely attacked, or have remained exempt altogether.

"2. Agencies which interfere direct'y with the process of breathing, and foreign substunces which enter the respiratory passages. Thes? too, as already indicited, are of a different character. When I first commenced my investigation, it struck me that all these swine -pigs, shotes, and grown hogs, of every age and descriptionwhich run at large in the streets and tboroughfares of Kansas City, Westport, Independence, Lexingto most independent life possible, but do not congregate, go home in the evening, and belong to parties who own but one, two, or may be three animals, as also all those swine which are kept by themselves, either one by one, or only a few together, and, finally, all those which are kept in comparatively small herds, in pastures, 
orchards, or woods, conted everywhere witl grass, and perfectly destitute of dusty, bare ground, and of old manure he:lps, are, remain, and have been, with rare exceptions, perfectly healthy. I say, with rare exceptions, for it has been reported to we thit a fow of these swine running at large in the streets have died, but I hare not been able to ascertain with certainty the causes of their death. On the other hand, all those animals which have been lept iu yards, pastures, or tields, etc., which consist parti..lly or wholly of bare, lusty ground, or which contain heaps and alscumulatious of old munure, have sutfered, and are sutiering severely, and the more so the larger the herd, and the worse the lust of soil and m:2nure. In large herds, composed of 100 hend or more, the mortality has been as high as from 70 to 90 per cent; in smaller herds, the same has been from 25 to 60 per cent, and where only a few animals have been kept together, and consequently each animal was compelled to inhale only the dnst kicked up by itself, and occasionally, by one or two others, the mortality has been rery low, has seldom exceeded 10 per cent, or no fatal cases hare occurrel at all. Further, in all those cases, in which the hoge or pigs liave been compelled to inhale, with each breath, a large quantity of soil and m:mure, ground to a fine powder by the rays of the s'm, and by heat, rain, wind, tramping, and rooting, all the post mortem examinations-and I hare made a large number during the last four weeks-have revealed as principal morbid changes a morbil aflection of the eyes, inflammation of the respiratory passages (th oat, wind-pipe, bronchial tubes), hepatization of the lungs in rarions stages of lerelopment, and, in some cases, eren some tubercles, or a few small abscesses in the pulmonal tissue, while the serous membrane (pulmonal and costal pleura, perieardinm, and peritoneum) presented themselves in a comparatively liealthy condition, except in those cases in which the causes described under 1 had acted with those under discussion.

"If these facts just related are duly taken into consideration, scarcely any doubt can remain that the constant inhalation of powdered soil and manure constitutes one of the principal causes of the epizootic influenza of swine.

"As another noxious influence, injuring the orgaus of respira. tion, may be considered the effluvia emanating from old, decomposing munure heaps, or farm accumulations of filth, and dirt in pig-sties or hog-yards ; but as these are only of subordinate import. ance, I do not deem it necessasy to enter into further details.

"3. The auxiliary, or aggravating, and predisposing causes. As such, I have to consider all the injurious agencies, or noxious in- 
Auences, which are calculated to promote or to derelop the typhoid character of the disease, to weaken the constitution of the aninal, or to produce a predisposition. As belonging to this class, I have to mention first, as having a very injurious effect upon the animal system, an impure, foul, or filthy condition of the water for drinking; and secondly, the filth and manure wich the animals are obliged to consume with their food. On most farms, the swiue are fed with corn in the ear, which, on a great many farms, is thrown to them with great carelessness, in the rery filthiest and dirtiest places, so that scarcely a keruel of corn can be picked up free from dirt or manure. That such a wholesale consumption of dirt and excrements must finally undermine the constitution of even the healthiest and most vigorous animal, and must give to any disease that may happen to affect the same some typhoid charucter, is too evident to need much explamation.

"3. The Cerebro-Rheumatic Form.-The same, though aiways bleuded with, and in a certain degree subordiuate to, one of the two principal forms, has been observed in a large number of sick animals. The latter, besides exhibiting all the symptums of one or another of the principal (catarrhal-rheumatic or bilious-rheumatic) forms, show also plain indications of morbid affection of the irain. These indications cousist principally in partial or perfect blindness, a rery staggering gait, and aimless morements in general.

"On opening the skull, I found, invariably, more or less swelling in the membranes enveloping the brain, a larger or smaller quantity of serum deposited inside of the hard membrane (duru zater), the substance of the brain more or less softened, and the mall cavities or rentricles of the latter organ filled with serum. The other morbid changes found at the post mortem examinations are the same that have been described under the head of their respective form.

"4. The Lymphatic-Rhermatic Form.-The same, too, has iver observed quite often, but always as a complication of one of the principal forms, described under 1 and 2 . The whole morbid pro. cess presents a somewhat scrofulous character. The 15 mphatio system is plainly affected; tumors and ulcers showing a s?rofulous character, are found in various parts of the body, but especially on the gums. Hence there can be no doubt that such cases, although complicated and blended inrariably to such an exient with one or another of the main or orincinal forms, as to make it impossible to draw distinct lines. have to be Jaokec upop as a eybordinate form, with a lymphatic character. 
"I hare becn informed repeatedly, by reliable persons, that in some of the sick auimals cutaneous eruptions have constituted one of the most conspicuous symptoms of the disease. If this is a fact, it is possible that yet a fifth (erysipeiatous) form has been added. Still, I have had no chance to examine such a patient, notwitustanding that $I$ hare seen a large number of sick animals, exceeding, I should judge, one thousand; I am, therefore, not prepared to decide whether the cutaneous eruption is a product of the same morbid process which is at the bottom of the other morbid changes, or whether the same is an independent disease, and merely an accidental complication.

"It is probably not necessary to mention that the morbid changes which have been described is the products or attendants of a certain form, are but seldom found as a total in oue and the same animal, as one or more of them are usually missing, or but little dereloped. Neither will it be essential to state that even the two principal forms of epizootic influenza of swine-leaving the subordinate forms out of consideration-are scarcely ever observed entirely independent of each other, or without being complicated in the least with any other form; that, on the contrary, the gastric rheu matic and the catarrhal rheumatic are, in many instances, blended and complicated with each other to such an extent as to make it impossible to decide which one has to be considered as the most predominating. In such cases, the symptoms, too, are bleuded with each other, and morbid changes, frequently of equal importance, are found in both large cavities in the chest and in the abdomen. These facts are easily understood by any one who is at all familiar with pathology and with morbid anatomy. The main or fundamental character of epizootic influenza of swine is always rheumatic, and principal seat is the system of the serous membranes, abounding in every large carity of the animal body. Serous membranes not only line the interior of those carities, but constitute, also, the external coat of nearly erery internal organ. Hence it is but natural that such disease should localize in many different parts of the animal organism, to produce, in consequence, different morbid symptoms, and to cause different forms of disease. It is true, that, in some cases, the disease exhibits a prevailing catarrhal character; but if it is taken into consideration that the causes of rheumatic affection and of catarrhal diseases are often essentially the same, and that the seat or character of a disorder depend, frequently, upon an individual predisposition of the animal, a further explanation will not be needed. 


\section{"THE CALSES.}

"To ascertain the causes has been my principal object. It was, therefore, necessary to observe a large number of cases, and to investigate the disease in different localities. This I have done, and hare come to the conclusion that some of the causes-and I tbink I am not mistaken if I say the most important onesare of such a nature as to admit removal, notwithstanding that they are liverse and numerous, and have their source, to a certain extent, in the manuer of farming and stock raising in the West. Although I will not deny the possibility of an existence of certain agencies of a so-called cosuic or telluric character, calculated to act as a cause or to contribute to producing the disease, I must confess I have not been able to discurer anything in the whole morbid process, or any norbid change that cannot be the prodnet of those noxious influences which I consider as the min, if not the exclusive, causes of the disease, and which, in my opinion, are well able to produce every one of those morbid changes, which I had an opportunity to observe. Those injurious influences, or agencies, which I am obliged to consider as the principal causes. act in different ways, for a letter survey, may be divided into two classes.

"As belonging to the first chiss, I look upon everything that is apt to cause an interruption of the perspiration, and in the secone? cluss I place all such noxious influinces as are able to interfere, directly, with the proecss of respiration, and all such foreign substances as enter the respiratory passages, and cause, thereby, congestion and inflammation of the respiratory mucous membranes and of the tissue of the lungs. There are, also, as I hare already mentioned, some other minor causes or agencics which contribute, in one case more, in another less, to the development of the disease, or which are able to cause the character of the sane to be more typhcid. These I will diseuss under the head of aggravating or auxiliary causes, after I shall have disposed of the main or principal causes.

"1. Injurious influences which act as a cause of the lisease, by producing an interruption or partial cessation of the perspiration. These influences are numerous, and of much greater importance than one, who looks at them superficially, may be inclined to suppose. The skin of an animal is a very important organ; it not only serves as a protecting tegument, but has also other vital offices which are scarcely of less consequence to the welfare of the animal organism than those of the lungs. The skin discharges, 
through its pores, a large amount of wasted material, gaseous and fluid, and absorbs ariform and tluid substances from the outside world. Consequently, it may be looked upon as an organ whose duty it is to supplement the functions of sereral other organs, but especially those of the lungs and of the lidneys. To ascertain the effect of a total interruption of the functions of the skin upon the anim.l organism, interesting experiments bave been made by Bouley, Magendie, Gerlach, aml others. A complete iuterruption was bronght about by covering the shin of rarious animals with an air-tight coat of Varnish, greasa, or tar, and the results, according to Gerlach, have been as follows: 'Accelerated pulsation, extraordinary fullness of the arteries until an increased discharge of urine made its appearance, somewhat aceelerated breathing, trembling of the whole boly, rapid emaciation, great debility, augmented secretion of an aibuminous urine of gall (bilitulrin and bitiverlii), and a decrease of the animal temperature. The latter, howerer, became not rery conspicnons before the animal hat become emaciated and was near lying. The animals (horses) so treated died in three to ten days.' Pirs conted all orer with grease, for the purpose of killing lice, tied within a week, and showed the same symptoms.

“2. The oftice of the skin, at least so far as the processes of elimination and absorption are concerned, bears also a rery elose relation to the functions of the direrse serous and mucons membranes. It is true, if the skin is disqualified to perform its allotted duties, or if the latter are interrupted by some means, the same will parrtially be performel, but partially only, by those org:ms named, the lungs and the kidners, which, in such a ease, will make extroordinary efforts to maintain the equilibrium in the organic change of maierial, as indispensable to the preservation of hcalth. Still, as I have sail, thes: organs, in addition to their own duties, can onlypartially perform the functions of the skin; certain parts of the wasted materi:l, constantly prodneed, will not be discharged, but will remain in the organism. The lungs, the hidneys, the serous and the mucons membranes, if I may use the expression, will be orerburdencl, and the consequence will be that just those organs will be the tirst ones that become liseased, or that will have to sutfer from orer-exertion, and from the injurious effects necessarily produced by a retention of wasted material in the organism, and by a constant loss of organic compounds that cannot be spared. That such a loss is taking place, if the perspiration is interrupted, has been proved by the experiments of Professor Gerlach, which shows that the urine, in such a case, earries uff albumen. Fur 
ther, that such an interruption must necessarily produce a disturbance in the circulation of the blood, which results in an extraordi. nury flow of blood to those organs-lungs, kidneys, etc, - burdened with increased functions, and constitutes in that way a cause of congestion aucl subsequent inflammation, is too evident to need any further explanation. At any rate, these facts will be very plaiu to any one who has ever suffered from any cold.

"Finally, I wish to say a few words in regard to a hygienic mis. take committed on almost every farm in the West. I refer to the prictice of feeling the swine almost exclusively with coru, a practice which certainly is not calculated to produce healthy and vig. orous animals, but which necessarily must result, as I shall try to slow, in weakening the organism, and in creating a predisposition to disease. How much or how little this practice lias contributed to produce the now-prevailing epizootic influenza of swine, I am not prepared to decide. I liave, however, reasons to suppose thit this practice has not been without influence. The organism of a domestic animal is composed of about fifteen or twenty clements, or undecomposable constituents of matter, united to numerous organic compounds. A constant change of matter is taking place, and il part of these elements, in the form of organic compounds, is constantly wasted, and carried off by the various processes of secretion and excretion. The organism, therefore, in orler to remain licalthy, and maintain its normal composition, must receive, from time to time, an adequate supply of those elements, contained in suitable or digestible organic compouncls, so as to cover the continual loss, and, if the animal is young, to produce growth and development. The simplest way to introduce the elements into the animal organism is to give food which contains them in nearly the right proportions. A few of these elements besides hydrogen and oxygen, are sometimes in the form of suitable compounds, contained in limited, though very seldom sufficient, quantities in the water for drinking; for instance, calcium (in the form of lime), iron, etc. One importunt element-oxygen-enters the organism, also, in large quantities through the lungs and through the skin, but all others have to be introduced wholly, or almost wholly, in the form of food. Almost all kinds of fluid, lowever, milk perhaps excepted, lack some important elements of their composition, contain others in insufficient quantities, and still others in greater abundance than required. Therefore, if such a kind of food is given cxclusively-corn, for instance,-which is destitute of some of the nineral elements, and contains only an insufficient quantity of nitrogenous compounds, which are of so great an im- 
portance in the animal organization, irregularities and disorders in the exercise of the various functions, and imperfect development of certain parts and organs, will be the unatvoiclable results.

"One may ask, if the causes of the cliseases are of such an ordinary character, how can it he possible that it has become such an extensive epizooty ?-The answer is not very ditheult, and an explanation is easily given. At tirst, notwithstanding the most diligent search and patient inquiry, I have not been able to discover any injurious influences or agencies of a general character besides those enmmerated, which, possibly, might have acted as a cause. Secondly, the treatment or the keeping of the swine is essentially everywhere the same in all the Western States. The causes mentioned are, therefore, of a sufficiently universal character to produce an epizootic disease. Our western farmer, as a general rule, careless enough, if possible, in his treatment and care of his horses and cattle, usually thinks a hog is only a "hog;" can get along with "hoggish" treatment, clelights in nastiuess, filtl, and dirt of any description; does not neel a dry, conıfortable, and clean resting place during the night, nor clean and fresh water for drinking and bathing; nor shade and shelter against the burning rays of a western sun, against cold dews of the morning, or the sudden changes of weather and temperature in general.

"Sonebody may object, and may say, if the principal causes of the disease hare their sources in the manner in which the swine are raised and provided for, which does not differ essentially from what has been since the country was first settled, how then does it happen, or how can it be explained, that the disease did make its appearance as an epizooty only a few years ago, and not immediately among the swine of the first settlers, or while the country was yet new, and is now increasing in riolence from year to year? This question is not difficult to answer. While the country was new, pig-sties, log-yards, hog-lots, and pastures, and the places which contained the water for drinking and bathing were not yet contaminated and impregnated to such an extent as they are now with filth and excrement; bare and dusty ground was less abundant, and the ummber of swine kept together, on one dry place, as a general rule, was a great deal smaller. The lisease will increase in malignancy and spread in the same proportion in which dung and dirt is allowed to accumulate, and in which the size of the herds is increased.

"A great many farmers believe, nay, hold themselves convinced, that the epizootic influenza of swine is a contagious disease, and they have kindly furmished me facts which, I admit, point very 
strongly that way. To tell the truth, I am not yet prepared to decide that question, because such a decision requires numerous experiments, and these I have not been able to make. Still I am inclined to think the epizootic character, or the fearful spreading of the disease, can be explained satisfactorily withont the existence of a contagion. The fact that the hogs and pigs running at large in the streets of the cities, with a fer exceptions, are healthy, and reuain exempted from the disease, goes far to show that the latter is not communicated by a contagion, as animals leading such a ragahond life are, as a general rule, much more exposed to the influence of contagions than any others.

\section{"DURATION OF THE MORBID PROCESS.}

"In some cases the disease has lad a fatal termination within two days after the tirst plain symptoms of sickness have made their appearance, and a few cases have been reported to me, in which the animals have dicd within six or twelve hours; but I am inclined to think the first symptoms have escaped observation-a very common occurrence in diseases of swinc. The average duration of the disease may be set down as from fire to fifteen days. Still some animals have been sick from three to six weeks, but most of them have recovered, and then a part of that time belongs to the stage of convalescence. Or if the patients have died, the duration of the discase has been protracted by relapses.

\section{" PREVENTION.}

"The measures of prevention consist in removing the causes as enumerated above. If this is done, no other special treatment will be required to ward off the disease, and no medicine will be needed. To gire medicine to a healthy animal is, under all circumstances, a bad practice, fraught with injury, and should not be done, unless it is intended to destroy injurious influences. To use medicine for the purpose of strengthening the constitution of an animal, is simply folly, as just the opposite will be the result. But to the point: I am confident the epizootic influenza of swine, or the disease improperly called hog cholera, will cease to make its appearance, or, at any rate, will become a very rare occurrence, and will lose its epizootic character, if, first, every large herd of swine is divided into several small herls, or lots, each containing about three or four animais; if, secondly, cach lot is provided with a comfortable pen or place to sleep in, which is free from filth, dust, and manure, is well rentilated, and provided with a good roof; if, thirdly, every hog or pig has access, sereral times a day, or as often as tempera- 
ture, weather, and circumstances require, to fresh and cican watcr for drinking and bathing, either in a large trough or in a brook, creek, or streamlet; if, fourthly, no filth, manure, or dirt, is allowel to accumulate in any of the sties. yards, hog-lots, or pastures, in which the hogs or pigs are kept; and if, tinally, hogs and pigs receive always a suitable variety of sound healthy food, which is not soiled with dirt or unanure. I know very well some farmers will be dissatisfied with my adrice, and would have preferred to be sent to the drug store for medicines. Others would think to comply with my prescription will be too much trouble altogether, and some of them may say : "If we ean not keep our hogs any more in the old 'hoggish' fashion, hut must treat them like animals ought to be treated, we prefer to keep no hogs at all.' Very well, if they do not keep any hugs, they certainly will not lose any, and their neighbors, who continue to raise swine, and take proper care of them, will be the gainers in a two-fold respect. At tirst they will reap the benefit from the scarcity of logs thus producel, and, secondly, they will be amply repaiil hy their swine for the care bestored upon them. At any rate, it will pay much better for any one to raise, for instance, fifty hors, to keep them well in every respect, to lose none, and to develop them to first-class animals, (so-called 'Philadelphia' logs), than to raise 100 or 200 head, to keep them 'hoggish,' to lose more than fifț to serenty per cent, and to produce animals that figure as 'scaliwags' in the market reports. ILoreorer, the amount of food that is needed to produce 200 pounds of inferior, and frequently unhealthy, pork-if the pig is kept on a manure heap in the barn-yarl, or in any nasty hog-lot, and in the old common way and eareless fushion-will produce 300 pounds of good healthy, and palatable pork, if the keeping of the animal is always in strict accordanec with hygienie laws. If the latter are never riolated, the epizootic influenza of swine, I am sure, will not make its appearance; but if the mode of kecping swine is not chinged the disease will increase in frequency and in malignancy from year to year.

\section{“TREATMENT.}

"The treatment may he divided into two parts-a hygienic and a medical treatment. The former includes a remoring of eauses, and is alike in manr, or even in most, diseases, of the greatest importance. The sick animal must be separated from the herd, and must be provided with a clean, dry, and well ventilated resting place, which is not exposed to drafts of air, and which affords otherwise sufticient protection against hcat, cold, and wet. Tho 
same, further, must have, besides pure air to breathe, clean water to drink, and healthy and easily digestible food to eat. If the sick animals are thus treated, and the causes promptly remored, a grea: many sick animals (provited, of course, they are not too tar gone) will be sared by proper medical treatment; but if these directions are not complied with, even the best medical treatment will be of very little avail. As to the use of medicines, I would recommend to give to each patient at the beginuing of the disease a geod cmetic, composed either of powdered White Hellebore (Veratrum album), or of 'Tartar Emetic in a dose of abont one: grain for each month the sick animal is old, if the same is of fair size, but not cxceding sixteen to twenty grains, even if the animal is fullgrown or several years oll. The emetic is easily administrated by mixing it with a piece of boiled potato, or, if White Hellebore is chosen, (which I consider as preferable), hy sprinkling it on tho surface of a small quantity of milk. Boiled potato or milk will not be refused by any hog unless the patient is alrealy rery sick, or far gone, and in that case it will be too late to gire an emetic. After the medieine has taken effect, the animal will appear to bo very sick, and will try to hide itself in a dark corner, but in alıont two or three hours will make its appearance again, and will be willing, in most cases at least, to accept a little choice food, for instance, a boiled potato, a little milk, ete. At that time it will be adrisablo to give again a small dose of medicine, consisting cither of a few grains (two or three, to a full-grown animal, and to a pig th pro. portion) of Tartar Emetic, or of the same amount of Calomel, also mixed with a piece of hoiled potato; or, if appetite should not have returned, mixed with a pinch of flour and a few drops of water, and formed into small rouncl pills. A sick hog, I will remark bere, should not be drenched with medicine under any circumstances, for a drench given by force is very apt to pass down the windpipe into the lungs as soon as the animal squeals, and frequently causes instant death. The Tartar Emetic is to be preferred, if the disease has its principal seat in the respiratory organs, or presents itself in its catorrhal rheumatic form ; and the Calomel deserves preference if the gastric, or bilious rheumatic form is prevailing, and especially if the liver is serionsly affected. Either medicine may be giren in such doses as have been mentioned, two or three times a day, for sereral days in succession, or till a change for the better mill be plainly visible. It may also he advisable (but particularly if the typhoid character of the (lisease is rery manifested) to mix for each hog or pig, now and then, a few drops of Carbolic Acid with the water for drinking, or with the slop. Animals that 
are conralescent, and hare been reluced rers much hy the disease, and are yet weik, should receive, mixed with their food, small doses of Sulphate of Iron, (copperas), suy from tire to twenty grains, according to age and size, but the use of irom must be discontinued if the patient becomes constipated, or if the exerements turn black. Those convalesecuts in which the morbid process has produced considerable bepatization of the luugs, will he benefited by giving them repeatedly small closes (from ten to tifty grains) of purified Carbonate of Potash, for the puposo of promoting the alsorption of the exulation deposited in the tissue of the lumgs.

"Extcrually, a good counter-irritant, or blister, applies on both sides of the chest, and composed of c'untharides or Spanish llics and Oil (one ounce of the former to four ounces of the latter constitutes the proportion), hoiled forether over a moderate fire for half an hour, or in a water-bath for half an herr, will produce a rery beneticial result, especially in those eases in which the serous membranes of the chest constitute the principal seat of the morbid process. In most cases one applieation will be sutticient, provided the oil is thoroughy rubbed in and the disease has not made progress too far. If the first appliention should fail to raise a good blister (swelling and extulation), a second one may be made the next d:ı̣. In those cases, however, in which the morbid process has made too much headwiy, or has wrought too much destruction of tissue to admit recovery, the counter-irritant will produce no blister and no swelling whatever, a fact which constitutes a valuable prognostic symptom, for it indieates that the vitality of the animal is alrealy very low, and that a further treatment will be of no avali. Fontamelles or Setons have nearly the same etfort as a vesieafory or tly-blister, hut aet sluwer, and are less reliable, and may otherwise canse some damage, on account of the typhoid charater of the disease, by weakening the constitution of the animal."

In a communication from Dr. Detmers, dated Norembew inth, 1siti, he silys :

"Calling every diseaso of swine · hog cholera, has eimsed a great deal of mischief. ami the sooner that name ean be abolished the butter.

- Anthrax discases are cntirvy different from what I foum in Missouri," [rlescribed in foregoing report].

"There is nothing in common but tho epizootic character." 


\section{CHAPTER YXV.}

\section{SO-CALLED "HOG CHOLERA."}

Dr. N. II. Paaren, late State Veterinarian of Illinois, in reference to accomts of fearful ravages of " $\mathrm{Hog}$ (Holeri" in Missomri and Illinois, wites as follows in regard to this much dreaded seomrge :

“*** The different forms in which anthrix fever levelops itself, manifest ditlerent symptoms, among which the following are some of the most prevalent: The anmals suddenly appear dull, separating themselves from the herd; and totally refusing food and water, they scek dark places, or dig themselves beneath the litter, or into the ground. Symptoms of colic and a disposition to rest on the belly are amongst the signs indicating abdominal pain. Diarrhea soon sets in ; also occasional violent retching and romiting. The animal is not able to move freely, on account of weakness in the hind quarters-it staggers, and at list, paralyzed, it cannot move. Deglntition is interfered with, and the breathing is diflicust. Painful swellings oceur around the throat, extending downwals to the chest, which swelling is hard, hot, and painful. 'There is also frothing at the mouth and a painful congh, and appearance of boils. Sometime before death a discoloration of the skin appears on the neck, the ears, the back, under the belly, or the inside of the hind extremities, which discoloration, from being at the beginning of a bright-red or purple color, at the last stages of the disease nttains a dark-bluish or black color. The visible membranes of the mouth and nose attain a dark lirid color, and the mueous membranes of the cyelids and the white front of the eye become dark-red. Death occurs often very suddenly, and in most cases within twelre hours to two or three days. Recorery is seldom, and generally very slow, if erer complete.

"Post-mortem examinations revenl, in all cases, the most un. mistakable signs of the true nature of this disease. Putrefaction sets in very (puickly. The membranes of the nose, mouth, and rectum, are of a dark color. Dark hoody tluil is often observed to ooze from the nose and the reetmm. The espillaries and small reins of the skin, as also the tissue mbler the skin, are of a dark color, and overtilled with dark bloot. The bacon, diminished in 
quantity, is soft, sometimes of a rellewish color, snd blood-stained. In arimals that die suddeuly, the brain ame the spinst cont are found overtilleyt with blood. ()n opening the abtominal cavity, as most disurreable and fetid odur estapes: the stomach, the intestines, the liver, and the spleen, are overtilleyt with hlood sud yellow serum. The spleen, especially, is large, soft, of a dark eolor, sul overtillem with blood: sul the orsums of the chest are congested or stmeted with blend spots. The blowl is in s state of

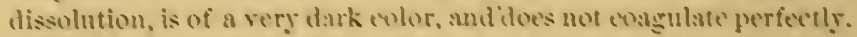

'The causes of the disciste are obseure: hut as it is mone prevaknt in low and undrainet? lexslities than on high and well-traineyt soil, it is considerit (1) be due mainly to miasmatic and matarioms cmanations continement in filthy sties, impur drinking water, and want of change in ford, ett., are also amonget the camses. Wo are conrimed that many animals of this class ane am andly last from the ctlew of improper fowd, or from living in an atmosphere surharged with poisonous etluvia, the product of snimal or veretahle decompesition. Deromposing substances hoth suimal

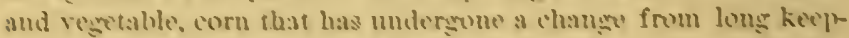
ing or expesure to damp, sund which is losled, perhaps, with the spormes of foisonous fungi, brine fom the meat tub-these and other similar substances are offen sive't to piss as food, and in many instanees have heen known to canse very great hises Much that se have seen eonvinces us of the nerysity of moro strention being poit to the quality of the ford of these snimsls than is generally ixing done, and also to the nature of their lods: in s.s. as well as the air they breathe.

"The treatment is most unsutisfortory, owing to the sente nature of the disense: in fact, sll nemedies sure useless when not atministered as sown as the int symptoms sppear. When the disease broaks out in a hert, the animals should be kept on low diet, have plenty of exereise and fresh air. In the early stane of the disesso cold water sluhings, often repeateyl, have provet betertial, and, so has the methoit of hurying in the earth in a cent such dark

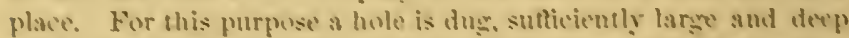
te attuit Mr. Pork sidewise, the lews being provionsly tied with a

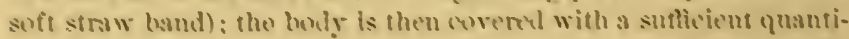

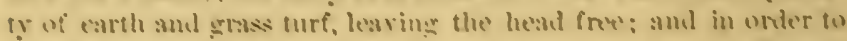

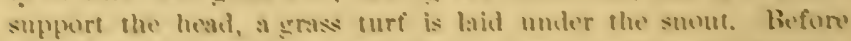

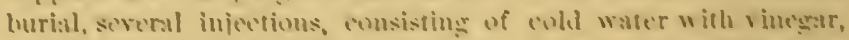

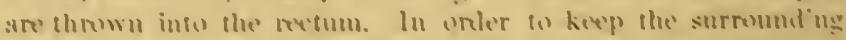
earth eonstantly (4) it. The anims! remains thus buried until it rewrers, which, it 
suceessul cases, buppens within six, twolve, of eighteen houls, Hog chelera is trested in many ditterent ways, each having its

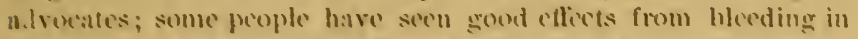
the earlic'st stinge's of this disense. Fometies and purgatives, in commetion with lukewam injertions of salt water with vinegar, are rery strongty reommemede In the begimning of the discase, sheres has also affemeted the administration of nn emetic, such as

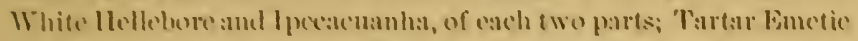

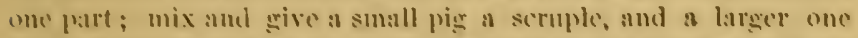

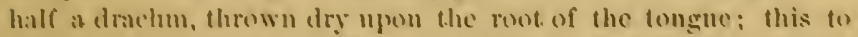
lic followed up by purgatives and clysters. Purgative to consist of binen silts, one, two or three ounces, necorting to the size. ant age of the suim:al, atministered in broth or swill from in botfle, Fixerise, fresh atr, and slubing the animal over with cold water are monsures to be reommended. Animals that recover, unless woll treated, comtinue tosutior from partial parilysis. or from rhemuntic intlammation of the joints.

". Is " an omoce of provention is worth more than a pement of cure; a few rematis concerniug this may nes be out of place. lirst of all, arodid, as far ats prossihle, all timlse's of this malady. Nover keep sick and sumnd sumals together; ndept remere separation and chese watching. Leep the animils on spare allowance of well-cooked mimst food, wholesome dice, fresh and clear water, fresh air sud goul litter; in fact, chanliness in every respeet is the best preventive anginst the disense. A few large piens of rock salt, as well as charenal, shombt be kept in the hour pert. Let. the hengs have plenty of fresh water, hut mever rum them to and from watering. Dont compet your hogs fo drink sumw water, if better winter is procuratile. In hot smmmer time, keep the hougs under sheled during the hotfest hems of the day, especially if hog cholers is prevaling: during which hours, if

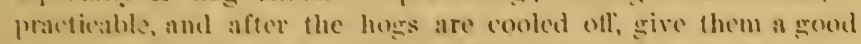
slucing with cold water, which rejest before letting them ont in the afternoon. Znripe fruit and sour mitk and water is a geot diet in hot weather, but. the hogs shombl not be griven more than they can eat at one meal. Besides this, it is atrisible, where and when hegr wholers exists, to give an oce:asional emetw. During an

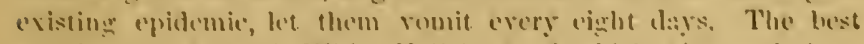

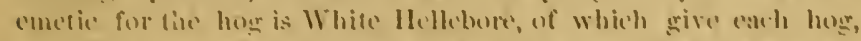

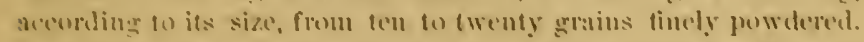
It is hest given in the merning, carly, hefore feeding. Mix the duses for each hog in a bucke, with some sour milk, and let him drink it. Duriug that day keep the hogs at home, under shelter 
and feed sparingly with some sour milk or unripe fruit. As it is a matter of great importance to kecp the howets in good order, give occasionally some Saltpetre in the drinking water during the following seven days; and-het us repeat $i t-$ the hogs must have plenty of fresh and elean water. Prerention hy cleanliness and comfort, release from restraint of pens, and the use of salt, tar, coil, ashes, sulphur, ete., have numcrous testimonials of etlicacy.

"When a destructive disease threatens the animals, and, through them, the most valuable section of our niti ual wealth, it shonld be the duty of all concerned to ohey the dietates of seienee and experience in order to arert danger and loss. But it must be confessed that to ohtain successful results indiridual etfints go for little. It is on the striet observanes of simitary laws, and to sie wise measules preseribed by authority, that relimee must be placed. In the words of an eminent melieal writer, "The day has grone past for an isolate. individual or eraft to avert pestilenee, as Empedocles did when he shut out the siroceo by stopping a mountain-gap, and removed intermittent fevers hy elanging the course of the river IIypsa.' These large and beneticient operations are in our day resersed for Governments; and our duty is to urge upon foverument, hy means of our troverning bodics, the necesity of undertaking the prevention of epiclemic diseases, hoth among men and animals, to point ont the lost modes of securing this prevention, and to see that these measures, when hecome law, are propily carricl out. The prevention of epizootic disenses ameng our domestie animals should he remrded as a political question, involving more or less the well-heing of the whole community; not merely affecting those who own or who endearor to derive protit from rearing animals, but also affecting the public at large, as regards bealth, the supply of food, and other essentials. In the cxteusion of a discase of this kind, not only is there loss to the iudirituals who possess the animals, but also to the puhlic, who have not only a diminished quantity or more expensive supply of foul, but also often ineur the risk of ohtainiug it of an inferior or injurious quality, or are otherwise inconrenienced.

Almost all the diseases of swine seem to be popularly resolved into 'hogg cholerso.' Of all cliseases of domestic animals, those of this genus are eridently less thomongly understood thin those of any other farm stock. lileas on the snbject are in a singular state of confusion, and remedies are countless in numluer, and most ineomeruous in character. If the symptomis were acenrately nofed, it would probably be found that several kinds of 'ho cholcra' 
- sis every prevalent disense of the hog appears to be colled-are uniting in the mischief protuceel.

Arricultural stock sutlers serious neglect. We venture to assert that ninety per cent of the clomestic animals of the farm which suffer from disease throughout the United States annually, are never seen hy Veterinary Surgeons. It is most singular that the Amerieuns, who have manifested the greatest activity in the promotion of serence and the useful arts, have never heen able to found a thoroughly etlieient Veterinary Coliegre. We number among ourselves but few Veterinarims; and most of them-we may say nearly all-hare been induced to leave Eurupe. Is it to be wondered at that our live stoek are eut down by disease in a most disastrous manner? Is it to be wondered at that we are now asking how we may remedy an evil which is found to be of far grenter importance than we ever before imagined?

Indecl, the ignorance of those who hold foremost positions amongst us on the subjeet of the amount of disease in the country - the Department of Agrieultura, especially-can only be expl ined by the fact that if we do not search for information regarding mortality amongst stock, we are not in the way of greaning it at all. Disease is ra fing frightfully without intermission. Truth must previlil in the end, and no better eonfomation of what we have said eau be olitined than that derived from the state of anxiety aad alarm which now exists throughout many portions of our country, where mortality anongst stock is among the daily records of our newspapers the whole year round.

Examples and estimates, after all, give but a slender itlen of the derastition, misery, cmbarrassment and loss that has been, and is due, in rery great measure, to the ignorance, apathy and negleet shown by those in anthority. Te speak but the sentiment of the stock owners and breelers of the coutry, when we express our earnest regret that the Department of Arriculture pays so tittlo attention to the investigation of the causes an! cliaraeter of the disensns of our domestic animals, in which the iuterests of all classes of arrieultur.sts are so largely concerned. In riew of the great importance of this matter, the great interests at stake, and the preralence of epidemic diseases among our domestic animals throughout this vast country, it is simply astonishing that the Departument of Agriculture contents itself with gathering in the statisties of mortality, utterly nerleeting the most important object of recommending or providing remedial means, or institute proper scientific investigations for the benefit of the sufferers and the public at large." 


\section{James Law. Professor of Veterinary science in Cornell} Unirersity, grives the following as the causts, symploms. and trealment of hogr choleras.

". Ple period of imenbation is from seven to fourtecn days, but is less in a hut olimate.

"C'unsss-Contagion, privation, starration, continement, tilth, etce

"symptoms.-Cieneral ill heshth, shivering, fever, great dulhess, prostrating fever, hidts under litter, lies on belly, weakiness of hind limbs, and later of the fore limbs, rapicl, weak pulse, dry snout covered by hluod-stamed spots, which also cover the skin,

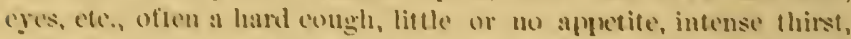
tender abdomen. After death, blowd-staining infiltrations into lings and bowels, uleers on bowels.

Trestment.-(iive cooling, acid drinks, Buttermilk, Sulphuric Achid, etc, feed soft, mucilaginous food, such as ()il-cake. Atlminister cwenty drops of Perchloride of lron twice a day. Blister the ahdomen by means of Mtustard and Turpentine; stimulate if very prostrate.

"Provention.-Aroid all dehilitating conditions, poor or spuiled food: keep animals constanty thriving. Fed charcual or Ashes, "lso 'Tar or Carbolic Acid. Avohid comlant with dise'sse. Burn in. fectid piggeries and remore do a ne'w place."

In further enments on the disciso Prof. Law s:lys:

"Fxamples, which might he very greatly" extended, imply that a sonnd mixed diet is of gresat importance in maintaining a healthy activity of the varions orgatule functions, and a viger lo a large crent antagonistic to this and other distases, and that a somewhat similar immmity may be secomed by the us. of tonic's, antiscepti's, and gently stimulating agents. lisut if we rest our fath upen suy or all of these as sure enres or preventives, we shall only pave the way for distppontment whenerer the distase takes on in unnะuslly malizu:at type. Thus, in spite of the protective power of a partially milk diet, as ahove mentioned, hew often doe's the

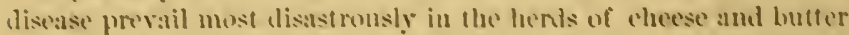

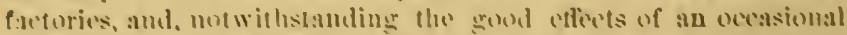
meal of thesh, we timd the must avernsive lusses among pige that are largely carniromols, (thesh cathen), in their hathits.

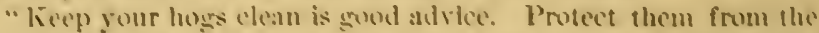
hot, resking bed of mamure and chse slexping place, where the cmanatious from decomplnsiug duug, urine, straw and other organio 
matter are added to those of their own skins and lungs when hublderl together in great numbers. See that hoth food mol water uro clean, in the sense of heing lire from disetse germs, und from the microscopic particles of decomposing organic matter, which, within the system as woll as outside of it, furnish appropriate food for the disease, poison, and fuvor its inerens', while they depress the vital powers and lessen the chances of the virus being thrown otf. No less important is the purity of the air, since the delicate membrne of the lungs, perhaps nore than my other, furnishes an easy mode of cutranee for any injurious external matter. Finally, purity of the blood ean only be maintained by a healthy functional activity of all the vital organs, which insures the perfect elaboration of every plastic constituent of the blood, and the exeretion of all waste matters that have already served their purpose in the system. By perfect etemliness, the poison, even if gencrated or introduced, will be vlrtully stirved out us surely as an army in $n$ closely besieged fortress. 13ut it will be observed that this implies the separation of sound from diseased animals, and tho free use of disinfectunts, (solutions of sulphate of iron and chloride of lime, fumes of burning sulphur, ete.), to purify the air ancl otleer surrounding ohjects, as well as the simple clenring away of tilth. And it is here that the pork-raisers are most frequently at fiult. Fifty or a hundred pigs are allowed to erowd ungether in n filthy manure he:ap, a rotfen straw stack, or under a baru subjected to the droppings of other animals, as well as their own produets. Thair feeding trongls and drinking water are so supplied that they ('an get into them with their filthy feet, and they must derom the most obmoxions matter or starve. If, under this abuse, disease is developerl, the healthy are left with the sick, as 'they will all hatve it any' Way, and the result is usually a clean sweep. When hog cholera exists, the sick should be placed by themselves under is sperial attendant, and under the free use of disinfectants; the healihy should be earefully watehed, and on the tirst sign of illness, an incrinstel temperature, to be asecrtained by the introduetion of a clinical thermometer into the rectum, they shonld be at one taken from the hesel and earefiully sochuded. This, with netive disinfertion, will enable the owner to ('ut short an outbreak. and save perhapss the great majority of :m ulreaty infected herd, Agan, the sale of animals fromi an infertial stock, to be removed from the promises alive, should he severely punished, nnd the disinfection of the buildings where the sick have been, should be male imperative. We shall obtain the greatest success with this disease when we treat it as a contugious maludy, and whenever it 
is found to exist, give our main attention in prevent the furthet gencration and dissemination of the poison."

'The following is collated from the correspondence of the Prairie farmer, and coming direct from men $\mathrm{cm}$. phatically practical, it is well worthy consideration. Mre John S. Bowles, of Hamilton, Ohio, writing to that jomrnal in Norember, 1sis, for information about Hog Choleri, says:

"I will now describe the disease of which my hogs are dying, and of which a great portion of the hoges in this rieinity are niso dỵing.

"The first symptom is a dullness or slcepiness in the netions of the hog. He walks to his food instend of rumning. He holds his head down within two or three inches of the ground, and should he raise it, he holds it slightly to one side. He eats his fool as though he had no appetite for it. Ife does not lie down with his fellow hogs, hut mopes about, lying ly himself, often in the sun instend of the shade. After the disinge prongresses a lithle, the hog refuses to eat altogether. Ifis ears swell. Sometimes a little purpleccolored blood will run from his nuse. Sonetimes, but not in the majority of eases, he will have a diarrhera. If he is a white hong, his ears and the lower part of his throat and between his fore leves turn to a purple hue. Sometimes he dies in two days, and sometimes he lingers for two weeks. The latter part of his illuess he heaves at his tlanks, having what is ealled the 'Thumps.' He is also very weak in his hind equarters. Whe'u he is driven up he starts with a squeal, as thongh much frightemed, and runs ofle reeling on his hind legn, with his nuse nearly down to the gromul.

"This season is the tirst one I have erer been troubled with hog cholera, and I have every rason to believe the disense originated on my own farm.

"Tihere were disosed hugs all through the neighborhood for two months previous to mine taking the disenst, but I do not think mine had any contact with suy of them, or in fact with suy hogs but their fellows.

"The disease broke out in my hougs in st ticld which has a stream of spring water running through it. It is an old sugar camp, ninetenths cleared, but the hogs could be in the shate all the time if they wished.

"The rest of the tield, where there were no sugar trees, is a clorer 
pasture. There was un filthy beds, or jerns, or bad water in tho cuso-an the eontrury, quite the reverse.

"At the simus time I laul 4.1 liogs taken from the samo lot us these store hoges, that were in three hoard pens, side hy side. 'These

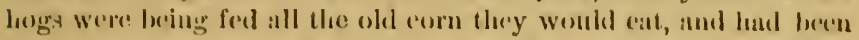

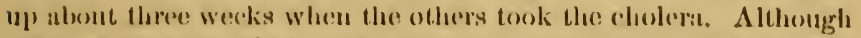
they laty considcrubly in their own filth, and lath n large manure hemp on one side of them, nome of them took the cholerit; for four weeks it loroke ont musner theil aljoining leollows, mol until 18 of them loud died. Now one (only), of the fattening hogy is sick.

"The loggs in which the disinas hroke ont hid been on clover patsture, ulone, fluring the early part of tho smumer. As I lad more loog a than chover, I soon fed them three ears of corn per day, ench. After lanevest, 1 turned the hogs on the whent and barley atublise, and arait feeding them corn. When the stubble gave ont, I commenced foeding the loogs threo stalks of grain eorn per day eac'! , corn being juat ont of the milk.

"Ticere was then nhmblance of clover pasture as ull my stubbles were sown with clover. I wantel, heswever, to kerel nuy hogrs in the s:me eondition they were muth my new (rop) of eorn was sulleciently ripened to feed them for fathening.

"In about two weeks they commenced dying, and ont of ubout 99, averaging 160 to 170 poumds, I have host 19, and several more are sick. Thinking the green eorn lath something to do with the disease, I sold th of the healtheest to a me iyblowing distillery, and wont to fochling the remainder with ary old corn. 'They seem to do hetere since I changed their diet-that is, they do not die so fast.

"I have an i.lei that green corn, second growth clover", tete, lave a tendeney to creite tho discase, thomgh I think the frimary eause is something similar to malarit.

"Can you give me any information on the sulject?"

"N. B.-Besides the 19 hougs, averuging 160 1hs., I have lust about :0 spring pigs, and 30 odd sueking pigs."

$$
\text { In a later issue, " } \Lambda \text {. M. Wr., of Odiu, Illinois, says : }
$$

"In your issue of last Saturday is a communication nsking the experience and advice of other farmers as to hog cloblera. I lave keren keeping hogs ever sine the disease tirst begun to he hearel of in the West, have been cleaned out several times by it, and therefure glatly communicate something of what I know about it. The symptems he deseribes are exuctly the same that I understand to indicate log cholera. My hogrs have taken it when they had free acess to the woods and hazle-brush, and all (with the exeep- 
tion of a few old brood sows) hare gradually died off. Then again they have had the disease when contined to the fields, not clover, but stubble and timothy meadows, and it has generally eommenced its altak soon after harvest, and was the most fatal about the time the most green corn was led, though I don't think the com had anything to do with it.

"Now for the remelies. I have been clear of it for several years, and for two years before that time, I stopped its ravages at once hy administering a prescription that was published in your paper. After stopping the clisease with that medieine the second time, I saw again in The Farmer a prescription reconmented as a preventive, and have used that since according to directions, and have had no symptoms of hog cholera in my herd. I don't aftirm that either is a specific, but such, as related, were the results; hence, of course, I bave great faith in the medicine, and hare no fears of cholera now in raising hogs. There may be others of your readers who have had experience with those medicines. If they have failed or otherwise, they would certainly do their brother farmers a favor by communicating the fact. I have the recipe for the cure in my scrap book, cut from The Prairie Farmer at the time, to date. It is : Sulphur, 2 lbs. ; Copperạs, 2 lbs.; Madder, 2 Ibs.; Black Antimony, $\frac{1}{2}$ llb. ; S.ltpetre, $\frac{1}{2}$ lb. ; Arsenic, 2 oz. The quantity is sutticient for $100 \mathrm{bogs}$, and is mixed with slop enongh for a few doses all round-a pint to each hog. Ench time I tried this, I lad about 50 liead, and not one died that was able to walk to the trough and had enough life left to drink.

"The preventive was published by Prof. J. B. Tumer, in 1S62, in The Prairie Furmer, and then again two years or more ago be sent you the same reeipe with some characteristic remarks, atfirming his contiuued reliance on its efticacy, which you published at the time. The paper was mislaid, and I wrote 10 Mr. T., and here is his

Recipe.-One peck of Wool-ashes, four pounds Silt, one pound Black Antimony, one pound Copperas, one pound Sulphur, quarterpound Saltpetre. Pound and mix thoroughly; moisten enongh to prevent waste; put in a trough in al dry place where the hogs can at all times at just as mueh as they please of it. If predisposed to cholera, they will eat it very freely, and it will make something of an item of expense, for in time; at other times they will eat less, or perhaps none at all."

Some time after the appearance of the above letter, Mr. John G. Dutrich, of Nolmal, Illinois, wrote : 
"In The Farmer of December 14, 1872, there was an article on hog cholera, written and sent to you by A. M. W., of Odin, 111. It eame to me just in time to save my lot of one hundred sholes and hogrs, and a nicer lot of the former could not have been foamd in the country a week before the article reached me. But that week took out about fifteen of the choice ones. I will only say that. I used the remedy as soon as I could get it, and have only lost one by cholera since, and that one would not drink."

Respecting the preventive, the venerable Prof. Turner himself, says :

"I know of no one who las had any hog cholera of account from that day, (186:), who has persistently made use of it in advance of the appearance of clisease. I have hearl of logs being actually cured, after disease sets in, by being scrubbed all over daily with Copperas water moderately strong.

"Hogs should at all times be supplied with stone coal, as they will then eat less of the above mix ure, and be less expense."

Mr. A. C. Moore, the eminent Illinois breeder of Poland-Chinas, says, in his Swine Journal:

"Of this disease, which has proved so fatal, at different times within the last twelve years, in nearly every locality, especially in the Mississippi Valley, much has been said, and much written. Many believe the inciting causes are to be found in the want of some mineral elements in the soil of this great, once-subuerged valley; but there are many theories as to its causes, and all of them are more or less substantiated by facts. It stems to present itself at different times and places, under varying symptoms. The first indications differ.

"Thongh I have never had a case of this scourge among my hogs, I have carefully examined the first appearances on several oceasions when it has visited neighboring yards and farms. The first symptoms that I have seen, in eases consilered to be cholera, were these: the eyes looked hollow, and deep set in the head; the hair seemed to raise, or rough up; there was a gathering of a larklooking substance in the inner corner of the eye; these were followed by the skin looking rough and scaly, ant of a dark-red color; then came vomitine and diarrhœa, more or less frequent, according to the violence of the attack. In many cases, there is a short and rery difficult breathing, the head droops or is held to one side, and a cough shows itself; the congh being peculiar in this-that the animal stops to cough, and puts his nose quite near to the ground, 
in fact, it seems as though lic conld not cough while walking, as is usually done with a common cough. The hog scems inclisposed to move, is stiff and 'drawn up.' There are other morbid conclitions which are ascribed to cholera, hut the truth seems to be that these conditions rary so much, and the indications or first symptoms are so different, that I an compelled to believe that there are many ailments called cholera that are not cholera. It is therefore that so many quack nostrums can get certiticates of cure from farmers, whose stock has perhaps been cured, but cured from what? They believe it cholera, and so certify, but when the same remedy is given to a herd tiat actually hare that disease, then it fails; such failure is not usually reported beyond the immediate neighborbood.

"I know it does not matter to the loser what the disease may be called that takes away his herd, so far as his loss is concerned, but until the observing and scientific world hare more agreement as to the causes and conditions of this dread disease, it may be in rain that we proclaim any remedy to be a specific cure. In case of actual attack from this disease, (haring no experience,) I should at once conclude that, so far as the diseased animal was concerued, the preventires and conditions hereinafter named, had not reached the indiridual case, either from $\mathrm{my}$ neglect to provide them at all, or in sufficient quantities, and 1 would apply them at once, with thor. oughness. I would also give an ounce of Cirbolic Acid, well dissolved, and mixed in slop for every twenty-fire head of my herl, and repeat this dosa every $t w o$ or three days, carefully noting conditions and changes. Above all things, remore an affected hog at the first positive symptoms, to a yarl or pen, if not by himself, at least entirely separatel from the well hogs. Dispose of every carcass at once, and remore all filth of an infectious nature. If it be true, as claimed by some, that there is no specific remedy for this disease, it certainly follows that the 'ounce of prevention' must be thoronghly appliet.

"For all general purposes of health, and as a preventive from disease, I have, for many years, used the following mixture with uniform and marked bencfit. Take 1 bushel Charcoal, small piec:es; 3 bushels Wood-ashes; $\frac{1}{2}$ bushel slacked Lime; $\frac{1}{4}$ bushel Salt; 2 llis. Spanish hrown; 5 lbs. Sulphur; $\frac{1}{4}$ lb. Saltpetre; 1 lb. Ćopperas. Pulrerize the last two thoronglily; mix all in a bin, bcx, or barrel, ant keep in an open trough, wher $t^{\prime} 1 e$ bogs can have free access to it, and keep well moistened with gono swill, or milk. If your herd is nnt large, or sou lack a sufficient amount of some of the iugredients, mix smaller amounts of each iu the same proportion. Aim to keep these articles on hand at all times, and do not neglect their use; 
they contain certain chemical elements which are wanting in every hog predisposed to disease. You will soon observe, by careful watching, that the animal that looks the worst, and with which, as you say, 'there seems to be something the matter,' these are the ones that will call on you to fill this trough the oftenest, and they will usually visit it, either as they go to or return from their feed.

"A disease callei the choleri sometimes manifests itself by a short and quick, difficult breathing; the head droops, the back is raised, no disposition to move, 'yes loo's bad, a slight cough, of course no appetite; often diarrhœa attends the last stagre, in which many animals rlie. In such symptoms, I would try the Oil of Peppermint, prepared as an essence, but onc-third stronger. Put this into warm water, sweet:ned with sugar, and give two tablespoonfuls to each of your hogs sick, or subject to attack. A customer, in whose word and observation I have perfect confidence, writes me that he used this remedy in nincteen cases that were affected as above, and not one died, though every hog was lost on the adjoining farm that was attacked, though many other remedies were used."

A correspondent of the Louisville Courier-Journal furnishes the following as an "infallible remedy" for Hog Cholera :

"Dissolve thoroughly onc pound of Copperas in thrce gallons of warm water, and apply the wash about milk-warm to the affected animal, by dipping into the solution or rubbing upon it until the skin is thoroughly wet. Whenever the skin of the hog begins to look rough and scaly, or of a clark-red color, apply the wash immediately. Do not wait until the more alarming symptems (vomiting and purging) set in. Apply the wash every day, until the scales are removed."

Seeing accounts in the agricultural press, of the success of the Messrs. R. Kimberly \& Son, breeders of Chester Whites, at Green River, Henry connty, Illinois, in preventing diseases in their swine, by a simple-and, as they beliere, infallible-remedy, we applied to them for particular's.

Under date of March 1st, 18\%, they write :

"We have reports from eviry quarter, of cholera among swine, to an extent that is truly alarming. When we go to a market town, we see load after load of hugs that have died of cholera, 
and we know that it is raging on every hand, while at the samo time, our own herd continues healthy.

"Common 'Smart-weed' tea has prevented, and we helieve will prevent-if used judicionsly and in season-not only cholera, but the many diseases known by that name.

"In its green state, we pound the Smart-weed in an iron kettle, press out the juice and mix it, in small quantities, with good swill.

"When we discover want of appetite in a hog (that is the first symptom in nearly all (liseases of swinc), we feed them encugh of this to make them congh and sneeze greatly, and it has never failed, with us, to bring them around all right.

"TVe most fully believe that this remedy will not only prevent all cholera, but promote health and thrift.

"For use through the year the berb should be gathered when in bloom, tied in staall bundles, and liung in a sheltered, dry place, and when wanted for use, make a tea of it, by boiling. There are two kinds of Smart-weed, and the smallest, with the narrowest lears, is the one we use.

"We would not part with this remedy for any that bas yet been discovered, or is likely to be, for the next twenty years, especially as a preventive and general corrective.

"Disease, however, will continue to carry off a portion of the hogs in the comntry, so long as they are permitted to pile together in large numbers, in manure heaps, under some old barn or shed, until in a more than fever heat, out of which they rus's into a zero atmosphere at fecding time."

Milton Briggs, anthor of The Western Farmer and Stock Grouer, and widely known as a successful grower of cattle and hogs on a lirge scale in Iowa, wites:

"I supply all my hogs witis a compound of Bituminous Coal, Wood-ashes, or Lime and Salt. I place in a bin or box, open, so that horg can clig ont at bottom, and not run on to their feed. I place this bin so they can have access to it at all times. Five tons of what is called Slack Coal, with four or five bushels of Lime, or three to four barrels of Wood-aslies and one barrel of Salt, all mixed. This quantity will feed 100 head of hogs abont four months. All horg latring areess to this feed, will kecp free from disease, even if exposed to hogs having the cholera. I have purchased hogg that were diseased, having clolera in its first stages, and turned in with wrll hogs where there were large numbers running together. All symptoms of disease would soon disappear under this mode of 
treatment. The cholera hogs would soon begin to cast off their mange or scales from the skin, and assume a healthy appearance. A composition of Carbonate of Soda, Sulphur, Sulphate of Iron, and Carbolic Acid, will arrest the spread of cholera, in its worst stages."

Ezra Stetson, of Neponset, Illinois, a practitioner of medicine for twenty years, and for the twenty years prior to $18 \% 6$, a farmer and hog raiser on a large scale, by request of the editor presented his views and extended observations on the so-called Hog Cholera in a series of papers carefully prepared for the National Live Stock Journal, and he is confident the disease is of the same nature and origin as typhus fever in man, and belongs to a class of diseases caused by what he terms " crowd poison."

He has never known nor heard of an outbreak of this disease, except where large numbers of swine were kept together, unless communicated by contagion.

"It is only when the herd leaches into hundreds that the disease assumes its most malignant form and carries death and destruction in its path like a whirlwind." Extreme heat and cold are favorable periods for it; but it is prevalent all the year, and few animals escape that are exposed to its contagion. Dogs, wolves, and all rapacious animals or birds spread it, and to effectually prevent this, the dead hogs should be wholly consumed by burning.

Dr. Stetson thinks prevention is the only hope, and this must be accomplished by giving hogs proper accommodations, preventing their piling together, insuring them rentilation, shelter from sun, and protection from cold. "Merlicines, as such, should never be given them. No specific for this sty fever in swine, or typhus in man, has yet been discovered.

"Disinfectants are the nearest approach to safety from crowd poison that we yet possess. The most valuable is Carbolic Acid, and since nsing this-eight or ten yearsin my own herd, I have suffered no loss from this disease. The crude acid, a dark, tarry liquid, costing about 
nae dollar per gallon, is used at the rate of a pint to a bucket of water, and with this the nests aud woolwork about them are spriukled at least once a week. In omeo of the acid is oecasionally put in a harrel of swill or water for tho hogs to irink."

At a meeting of stoek-brecters and farmers of Iowa, held at II est liberty. during three days in Fobruary, 1Si\%, there was an extended disenssion on swine management. Mr. J. S. Long. of Jasper county, referring to hog choleri, said ho eonld giro some experience that he thought would be of value to all. Jears ago he lost thousands of dollars' worth of hogs. but for the last six years he had not lost amy, and he had a remedy, if any one would try, he would warrant they would lose no more hogs, provided they did exatety as he said, and the hogs were not past drinking, so they conld not take the medieine. He had tried it iu thousands of cases. and never had a failure; was now engiged in buying lots of hogs whore cholera prevailed: bought sjo reently, and fommd no tronble in emring them. His remely was this: " Mate Concen-

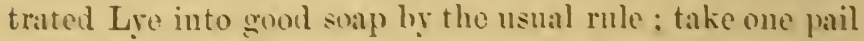
of the Sxap to tifty hogs: put it in a kettle, add water and two pomds of Copperas, boil it, then add dish-water and milk (or anything to make it taste grood) till you have about what the tifty hogs will drink. Place enough of the mixture, while warm. for twenty-five hogs to drink, in troughs, in a sepurate lot. Tust is you are ready to let the hors in. scatter two pounds of Soda in the troughs, the object is to have it fo:m ming as the hogs come to drink. be sure that erery log drinks. and if he will not drink, put him in the hosnital, and if ron cannot get him to drink then. knock him in the heid. for he will give the cholexal to the rest. After twenty-tive have had all they will. drink let in twonty-tive more. and entime till tho whole are treated. 'l'he next div l geo through with the same operation. After the secoud day skip a day, then 
give for two days, and you may turn them out cured. I generally give the same dose once a week to my hogs. An important point is to make the hog drink, and, if he will not take it any other way, add new milk, or put in sugar."

As evidence of his entire faith in his remedy and mode of administering it, Mr. Long offered "to pay ten cents a pound for every hog he could not cure, provided the hog was not past drinking."

\section{CHAPTER XXVI.}

\section{VARIOUS DISEASES COMMON TO SIVINE.}

While in the great pork-producing States the disease, or diseases, known as "Hog Cholera," overshadows in importance all other ailments of swine, there are numerous other diseases to which these animals are more or less subject. Some of these, such as Trichina and Measles, are of greater importance, from their effects upon man than for their injury to the swine themselves, and on this account call for vigilance in preventing them-as cure is out of the question. The leading diseases are here enumerated, and those remedies that have been found most useful are prescribed.

\section{WORMS.}

There is perhaps no animated existence that is troubled to so great an extent, or with so many varieties of worms, as the hog. Although savoring, somewhat, of quackery in principle, it is yet almost safe to say that, when your hog is sick, and you cannot tell what is the matter, doctor for worms.

"The principal symptom is a gormandizing appetite, without corresponding improvement in flesh, with an excessive itching, causing the animal to rub, especially the hind parts. 
"One, known as the round worm, is usually the size of a small goose-quill, and six or seven inches in length, of a brownist color, and somewhat corrugated.

"Probably the most effectual remedy that can be used is Santonin. This is the active principle of a plant called Worm-scel, and is the base of many of the vermifuges. It is in small white crystals, is usually very prompt in its action, and may be given in doses of one-third of a teaspoonful morning and evening, for two or three days, and following with a brisk cathartic, such as Calomel, in teaspoonful doses.

"Two other worms inhabit the lower bowels, or large intestines, generally near the anus, and may be frequently seen coming from the animal. One is a white slender worm, about three inches long, and as large as a knitting-needle; the other a little white worm, shaped somewhat like a tadpole, and half or threc-quarters of an inch long.

"Occasionally, these may be removed by giving one and a half tablespoonfuls of Barbadoes Aloes, with one teaspoonful of Copperas, each murning, for a week.

"If this fails to discharge them, after taking three or four days, an injection may be given, as follows: Tincture of Assafœetida, one tablespoonful; Salt, one teaspoonful; Watcr, half a pint; mix all together, warm silghtly, and inject.

"Such treatment as this may not be appreciated by the reader. But in these days, when a choice hreeding animal may cost two or three hundred dollars, we certainly should know all the remedies that may be required to save life or restore liealth." -(Dr Chase.)

\section{Mr. Moore says :}

"To swine that are troubled witl worms, mix Wood-ashes with Soap-suds, and feed once a week with their slops."

\section{TRICHINA SPIRALIS.}

This is a minute worm scarcely visible to the naked eye, that infests the flesh and muscles of man, the hog, and several other animals, such as dogs, cats, rats, and mice, and it was estimated by Teuckart that a single ounce of cat flesh, observed by him, must have harbored more than 300,000 of these parasites, which shows that under farorable conditions they accumulate in immense numbers.

They vary in length from $1 / 18$ to $\%$ of an inch, have a 
rounded slender bocly, with the head very narrow and sharply pointed, and although so diminutive, are among the most deadly worms known.

The mature and fertile worm lives in the intestines of animals, the immature in minute cysts (sacks or pouches) in the muscles, (see fig. 12), and these eysts only reach maturity and reproduce their kind when the animal they infest is devoured by another, and they are set free by the processes of digestion. Swine permitted to eat the offal from slaughter-houses, carrion, rats, mice, and decaying animal matter of any kind, are usually more or less infested with trichina, and its dangerous nature is a powerful

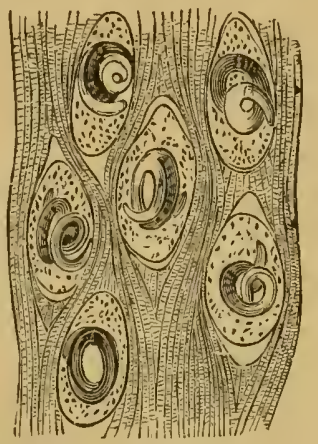

Fig. 12. - TRICHINA IN MUSCLE.-Magnifled. argument in favor of supplying them with food that is sound and wholesome.

In about two days from the time the trichina is taken into the stomach, it reaches the adult coudition, and about the seventh day the female brings forth a numerous brood of minute hair-like larva which soon begin piercing the intestinal walls, whence they proceed through the system, until they reach and penetrate the muscles. Their borings cause violent muscular pains, like rheumatism, for which in man it is often mistaken ; also stiffness, some fever, with diarrhœa, and much irritation for the first fortnight. The duration of an attack is from four to eight weeks, and the period of recovery as much longer. If the patient survives six weeks, recovery may be looked for, as irritation ceases when the worms have become encysted in the muscle.

An attack of trichiniasis where not at first suspected, is liable to be mistaken for typhoid fever. 
We have no knowledge of an instance where swine have been lost by being infested with trichina, and the treatment of human subjects so affected has been by the most skilled physicians considered far from satisfactory. Those most familiar with the symptoms recommend, especially at first, cathartics and vermifuges ; Castor Oil, Glycerine, Benzine, Alcohol, and Picric Acid are named.

IIogs that run at large, or are treated with neglect, are always liable to have trichina, and the flesh of such can only be eaten with safety after it is thoroughly cooked, and we have seen it authoritatively stated that these disgusting parasites will survive 140 degrees Fahrenheit.

Partially cooked ham, sausage, and similar meats, such as are kept on sale at cheap restaurants, eating stalls, booths, ctc., should especially be avoided.

KIDNEY WORMS.

Symptoms: Imperfect use of hind legs, inclination to lie down, a seeming paralysis of hind parts, inability to raise on the hind feet.

\section{Dr. Chase, in his work, "The Hog, its Diseases, and} Treatment," says :

"This worm infests hogs to an alarming extent, and though not fatal in its effects, is a frequent cause of disease.

"When full-grown, it is as large as a small wheat-straw, and nearly two inches in length. It inbabits the Ieaf-lard, in the neighborhood of the kidneys, and we have sometimes seen scores of them in the same hog. It is nearly black along the back, and of a brown color on the belly. It burrows along through the fat, and is a frequent cause of weak loins, and sometimes produces a slight inflammation of the kidneys. Turpentine is the only remedy we have ever found to be of benefit, and conclude that its rapid absorption into the circulation and through the kidneys, has the effect of driving the worm further away from those organs, when the irritation ceases. There is no way of expelling the worm from the system that we are aware of."

\section{Dr. Paaren says in the Prairie Farmer:}

"Kidney worm is not a common disease in hogs. Occasionally one or two in a number of hogs may suffer from the presence of 
one or more worms in the kidneys; but the ailment is not of ten tatal, and becomes so only after a longer time of suffering, and consequent disease or degeneration of one or both kidneys. When we are told that a number of pigs simultaneously refuse their food, lie down, become partly par.lyzed, or suffer from spasmodic twitchings, we are inclined to conclude that they are affected with some other ailment than kidney woruns."

An old farmer, of ta Salle county, Illinois, writes :

"I lately saw inquirie? about kilney worms in hogs, indicated by the loss of the use of the hind legs, etc. This disease tas prevailed very extensively les One tablespoonful of Turpentine poured on across the loins or small of the back, every day, fo. three days. I have never known it to fail, even when the hoys had been down for weaks unable to rise."

"H. D. Court, the well-known breeder of Chester Thite swine at Battle Creek, Mich., writes that he has fo:nd a teaspoonful of pulverized Copperas, mixel wit:ı an equal quantity of Sulphur, fed in the night's meal, for three clays, effective in this disease. Sometimes a longer treatment is necessary."

Corn soaked in lye made from wood-ashes, is a co: renient preventive, and is used with success when signs of the complaint first appear. Prof. Law says its presence 'n the kidney may sometimes be recognized by the existence of microscopic eggs in the urine. The same restilts from another worm-Eustrongylis giyas. But without observation of such eggs, weakness of the hind parts camnot be ascribed to kidney worm.

\section{MEASLES.}

Prof. Law, in his "Farmer's Veterinary Adviser," says :

"The bladder-worm of pork (Cysticercus cellulose) is the imma-

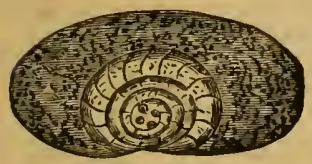

Fig. 13.-Cysticercus CELLULOSA. ture form of a tape-worm in man, ( $T_{c} \ell-$ nia solium), and is only caused by pigs having access to human excrement, or to places near privies, etc., from which the segments of the human tape-worm may travel. The cysts, respectively about the size of a $q$ rain of barley, are found in the muscles, in the loose connective tissue, and under the skin, in 
the scrous membraues, in the ere, under the tongue, ete, of swine. [Fig. 13 shows a separate cyst, enlarged; tig. 1t, gires the cysts of the natural size as they appear in measly pork.]

"They are also fouml in this mdereloped form in the muscles, brain, etc., of man, causing lisease and death. To man, the para-

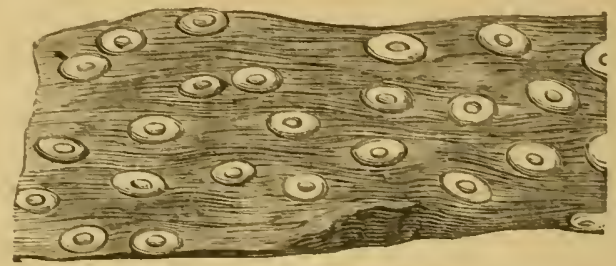

Fig. 14.-crsts of MEAsLes IN PORK.

site is usually conreyed by eating under-done pork, or in the cystic form he receives it as the egr in his food (silids, stc.,) and water.

"Srmptous. - In pigs, the crsts can nsully be seeı :under the tongue, or in the eyc. In man, there are the general symptoms of intestinal worms, and the pissinge of the ripe segments.

"Other symptoms may attend the presence of the cysts, accord.

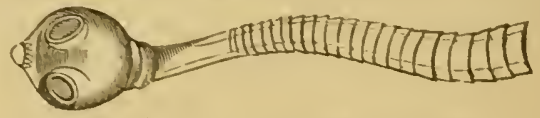

F.g. 15. - HEAD OF T.EXIA SULIT.M.

ing to the organ which they invale. Thus, when passing into the muscles, there are pains and stithess, resembling rhematism; when into the brain, coma, stuperr, imberility, detirium, but when they have once become encysted, they may continue thus indetinitely, without further injury.

"TREatuext.-The cysts scattered through the boly are beyoul the reach of medicine.

"Preventiox.-Human beings harboring tape-worms should he compelled to take the measures to expel them. Their stools should be burned, or treated with strong mincral acids. Swine should be kept fur apart from all human excrement: no such manure should be used as a top-dressing on pastures open to swine, or on lands deroted to the raising of regretables to be eaten ran.

"Aroid raw meat, especially pork, even if salted and smoked, and under-done meat aud sausages, also well-water, from grarelly soils, in the vicinity of habitations." 


\section{MANGE.}

"Mange, itch, or scab, in the lower animals is a skin disease of a purely local nature, due to an insect, which induces irritation, uleeration, suppuration, and incrustation on the surface of the body generally. It is a contagions disease, never originating, spontaneously, and requiring for its development the passage of the parusites or their eggs from diseased to healthy animals. In man, this disease is termed 'the itch,' and in the lower animals it is usually alluded to as 'mange,' and in sheep it is well known as a fearfully destructive disease, under the name of 'scab.'

"There are some important points in the history of scabies which apply to this disease, as it affects the animal kingdom generally. There is no species in the class mammalia that is not attacked with an insect inducing such a disease, if we perhaps except those that live mostly in water. It has been aseertained that though the weak, dirty, and ill nourished condition of some animals renders them very liable to the disease, they only become affected when diseased animals accidentally come in contact with them. A most important point, very clearly established, is, that althongh any animal may accilentally be the carrier of a contagion between other two, such as a cat or a dog carrying disease from one horse to another, that it is essential fur the development of a real scabies on any animal, that the insect should be proper to that inimal. Thus human beings, engaged around mangy horses, carry tie malaty from one animal to another, and sutler but very sliglitly, and only for a very short time, themselves. The parasite which lives on the horse does not live on man, and the parasite that lives on the sheep does not contaminate the shepherl's dog, though the latter may, like the shepherd, or the many rubbing-places on driftways, be the means whereby the malady spreads.

"The mange of the pig is due to the presence of a burrowing sarcoptes. Surcoptes suis is much like the lumman sarcoptes and the horse sarcoptes. Itch and mange are known to be essentially skin diseases, curable alone by topical remedies; aud the medicines used are valuable almost in proportion to the rapidity with which they destroy the life of the parasites which give rise to the irritation and other morbicl appearances.

"In treating the mange, we should first cover the body with soft soap, and wash it off some time afterwards with warm water, and have the animal well brushed; or a wash may be used, consisting of one part of Caustic Potash to fifty parts of water; or one part of Creosote to forty parts of oil, well mixed; or Sulphuret of 
Potassium in water, in the proportion of one to ten parts; or a decoction of Tobacco, in the ratio of one to twenty-five; or lastly, concentrated Vinegar. One or two days after the thorough ap. plication of either onf of these preparations, wash the body well with soap and water or potash lye. Whenever scabies is treated, it is essential to purify all objects with which animals can come in contact. Thus, all rubbing-places and sties should have a covering of lime, or chloride of lime. The sties should be cleaned out entirely, or the pigs removed for a few months to a new pen." (Dr. Paaren, V. S.)

Recipe for Mange Ointment.-Melt half a pound of common Turpentine with a pound and a half of Lard. Stir well therein a pound of Flowers of Sulphur, and when cool, rub down upon a marble slab, two ounces of strong Mercurial Ointment with these.

\section{LICE.}

"Lice are a sad torment to poverty-stricken and badly-kept stock, appearing by myriads, and causing excessive itching and irritation. They will effectually prevent an animal from laying on fat or doing well, as long as their presence is permitted. Various remedies and dressings are recommended for lice, and some are excessively dangerous, especially the preparations of mercury and arsenic,-the skin of most animals being extremely sensitive to the action of these agents. We have frequently recommended the following formula, as being both safe and destructive to lice: Stavesucre seed, four ounces; White Hellebore, one ounce; boiled in a gallon of water until only two quarts remain. Apply with a brush to the parts where lice are seen. A decoction of Tobacco may also be tried. On no account should mercurial or arsenical preparations be employed in these cases, as, from the great extent of surface it is often necessary to apply the dressing to, death has frequently resulted."-(Paaren.)

"We have used the following remedy, which will clean off the lice in two days: Put about one gill of kerosene oil in any old dish, and with a paint brush or old woolen rag rub the oil up and down the back of the animal, and behind the fore leg, and on the flank. Be particular about the last two places, for it is where the lice deposit their eggs, which, if not destroyed, will hatch out in about five days. If it be a black hog, these eggs can be plainly seen, being about the size of timothy seed, and laying close to the skin fast to the bair. No one need fear to use the oil freely, as it will not injure the bog in the least." 
"A Tennessee Agricultural paper says: 'W. S. Swann informs us that he has an infallible remedy for ridding hogs of lice, simple and easy of application; which is to take buttermilk and pour it along the hog's back and neck, and after two or three applications, not a louse will be seen. He has tried, and seen it tried, in several cases, with the same success in every instauce. Mr. Swann being a reliable man, and the remedy very simple, we recommend its trial to our farmer friends whose hogs are troubled with lice.'"

"A.C. Moore says: "Take two parts of Kerosene and one part of Lard-oil, mix, and apply to the hair and skin with a sponge or cloth; rub it well over all the parts where nits are liable to be found, and you have a certain cure. Two or three applications, if thoroughly done, will not fail. Be careful to cover the skin behind the ears and fore arms-here are the nits, and these are the places to attack.'"

"B. T. S., Mount Pleasant, Iowa, writes: 'Scotch snuff and hog's lard will destroy lice on hogs. One-fourth pound of Snutf and one and a fourth pound of Lard is sufficient for twenty liead. Rub the mixture along the back of the hog with the hand.'"

\section{PNEUMONIA.}

This disease is sometimes spoken of as "Thumps," but is more severe and rapidly fatal. Designating it as Inflammation of the Lungs gives a better idea of its seat and nature.

Its symptoms are loss of appetite, shivering, labored breathing, and severe cough. For treatment give the animals warm, comfortable quarters, free access to fresh, cool water, and every morning two drachms Saltpetre, or half an ounce of Hyposulphite of Soda in a small mess of gruel.

In this, as cther aiseases, feeding much dry corn is dctrimental to recovery.

\section{COMMON COUGH.}

This is known to many farmers as rising of the lights. It is sometimes quite troublesome, if not fatal. The prominent indications of the adisease are loss of appetite, incessant and distressing cough, and heqring at the flanks. 
As soon as the first symptoms are perceived, the animal should be bled; the palate is the best place; purgatires must then be given, but cautiously. Epsom Salts and Sulphur will be best, administered in a dose of from two to four drachms each, according to the size of the animal ; afterwards give a sedative, composed of Digitalis two grains, Pulvis Antimonialis six grains, Nitre half drachm. Cleanliness, warmth, and wholesome, cooling, nutritious food, are likewise valuable aids in combating this disease.

E. W. Bryant, of Illinois, breeder of Poland-Chinas, says, "my remedy for cough in pigs is oats. Feed once or twice a week all they will eat. The cough is caused by costiveness; the oats will loosen their bowels and the cough will disappear."

Of Thumps or Heaves, A. C. Moore says:

"I have never seen a case but it was preceded by a cough, which was gencrally worse in the morning, or when the pig first came from its bed. My ordinary remedy is to place a small amount of Tar, the bulk of an egg, well down in the mouth. This can readily be done, by the use of a wooden paldle, and should be done for two or three successive mornings. If the disease does not yield to three doses, I woul I dissolve one pint of Tar in a gallon of Water, and use one quart as a drench, repeating the dose every morning if required. I lo not believe there is a better remedy, though some recommend Tartar Emetic in small doses, mixed with the milk or water given as a drink, and continued from five to ten days. A reliable customer writes me, he has used Tartar-emetic in three cases with perfect success. Another says that two to three spoons$\mathrm{ful}$ of Salt, put well down in the throat, is a sure cure.

QUINSY, OR "STRANGLES."

This disease is of frequent occurrence, and rapid in its progress, and generally fatil, and mostly confined to fat hogs, or those fed highly. The first symptoms are: Swelling of glands under the throat, followed by rapid and difficult breathing and difficulty in swallowing; the neck swells ard gangrenes, the tongue protrudes from the mouth, and is covered with slaver. 
In the beginning of the disease, give an active emetic, such as the following; Potassio-tartrate of Antimony ('Tirtar-emetic) four grains; Ipecacuanha, six grains; White Hellebore, six grains. Mix and give in food, or throw into the mouth. If the animal will drink anything or eat a little, a purgative powder, consisting of two or three drachms of Castor Oil seeds should be given. When difficulty of breathing is great, apply an active blister over the throat, and give injections frequently. If the animal can swallow, and will drink water, some Salammoniac and Nitre should be dissolred in it.

'The recipe below, for Quinsy, is from Colman's Rural World:

"When the animal has the disease in a bad form, split the neck on each side of the throat so that it will bleed freely; swab the tincout well witi Turpentine; make it swallow one or two teaspoonfuls of it; if the subject will drink, this can be given in 'swill' Euough Turpentine poured on corn to make it oily, is a preveutive."

\section{NASAL CATARRII, OR "BULL NOSE."}

"First symptoms: Unusual discharge from the nose, the inflammation gradually extending to the pliarynx, gullet, and larynx. The animal sniffles, conghs some, nucous membrane swells, the nose thickens, and becomes twistel and distorted and ill-shaped, and when excrcised a little, the discharge from the nose becomes bloody, or is pure blood. The animal still eats reasonably well, but will not fatten nor grow, but gradually dwindles away, and dies.

"There is little cncouragement in trying to cure this, and it is consilered by some as leing of the same nature as glanders in lonses. Animals discovered with the disease should be destroyed, and removed from the farm."

INFLAMMATION OF THE BRAIN, EPILEPSY, OR "BLIND STAGGERS."

This disease frequently attacks swine, especially when changed to rich, abundant food, or exposed to stormy, cliangeable weather. At first the animal appears dull, 
stupid, and disinclined to move. The eyes become red and inflamed, the bowels constipated, the pulse hard and quick. In a short time, if not relieved, the animal runs wildly about, usually in a circle, seems blind, will run against objects, the breathing becomes rapid and laborious.

Treatuent.-Give, at once, a teaspoonful of Calomel, cut a slit in the skin on the hear above the eyes, cut it clear to the skull. In this cut put Salt and Pepper to get up a counter-irritation. If this does not succeed, make a liniment as follows: Take a four-ounce vial, into it put one ounce Spirits Turpentine, one ounce Capsicum, one ounce Aqua Ammonia, half ounce 'Tincture of Arnica, quarter ounce Chloroform ; shake well before using, and rub it on, around upper part of the head of the patient, and between the base of the ears and around them.

Professor Law recommends, when a hog is attacked, to dash bucketsful of cold water over the body, and throw into the rectum a purgative injection, composed of six ounces of Sulphate of Soda and one or two teaspoonsfuls of Spirits of Turpentine in ten ounces of Water. Setons saturated with the Turpentine may be inserted under the skin behind the ears; or the back of the neck may be blistered by actively rubbing in the following mixture: Spirits of Turpentine and liquid Ammonia, one ounce of each ; powdered Cantharides, two drachms. When it occurs in summer, or in hot weather, its severity can be greatly modified by providing shelter in a shed, where they can be in the shade during the lieat of the day; but at the same time a free circulation of air should be secured. Water, too, should be constantly within the reach of the animals, and, if possible, a pool of it provided in which they can lie at will.

Dr. Chase says partial recovery will soon occur after securing a free evacuation of the bowels. A teaspoonful 
of Copperas may be given twice a day, for two weeks, abating the feed somewhat. Also, to never bleed in this disease, as there is a poverty of blood already.

The North-British Agriculturist says the disease which is popularly termed staggers, in medical parlance is called epilepsy. It depends usually upon imperfect nutrition of the brain and nervous system. In pigs, as well as in other animals, epilepsy is often hereditary. Frequently it is developed by breeding in-and-in.

\section{APOPLEXY.}

Apoplexy only occurs in fat hogs, being caused by a too plethoric condition of the system. It demands prompt treatment, and is indicated by the stupid movements of the animal for perhaps several hours preceding its dropping, as if struck heavily on the head with a sledgehammer, when the limbs straighten, and but for its heavy breathing, it would be supposed dead.

Dr. Chase says :

"Bleed quickly, by tying a cord tightly around the fore-leg, above the knee, when the brachial vein will be seen to fill up, and may readily be opened with a lancet or sharp pointed knife. The vein is ou the inside of the leg, and should be opened about an inch above the knee.

"If possible take a pint and a half of blood, or even more. If this vein does not yield a sufficient amount, some of the veins on the insicle of the ear may be opened by turning the ear back and pressing with the thumb firmly on the base. Never cut off an car or tail for the purpose of drawing blood.

"If the animal recovers from a first attack, at the earliest possible moment give a quarter of a pound of Salts, and repeat it cvery three hours, until the bowels move freely. Feed lightly for a few days, giving occasional doses of salts, and the probabilities are that it will permanently recover. $* * *$

"Epilepsy, or blind staggers, is the only disease likely to be con. founded with apoplexy."

PARAPLEGIA.

Paralysis of the muscles of the loins in swine is of fre- 
quent occurrence, but usually does not seem to interfere with the appetite or general health of the animal.

1t is sometimes caused by a severe strain of the back, or blows on the back or loins, producing concussion of the spinal marrow. If such is known to be the cause, cold applieations may be tried, for a few days, on the loins and back. If the cause is unknown, and no fever is present in the back, a liniment, composed of equal parts of Cantharides (Spanish Flies), Olive Oil, and spirits Turpentine, may be applied, or, a seton may be insertel lengthwise under the skin over the loins. The animal should be given comfortable quarters, with freedom from disturbance by others, fed on sloppy, soft food and som milk, and if costire, frequent injections of warm water should be nsed.

DIARRHEL, OR SCOURS.

Young pigs are frequently troubled with diarrhœa. The discharges are of a whitish color, and pigs of sows that have a cold or catarrh are liable to be sererely troubled. It rarely attacks old hogs, but is often fatal to young pigs, if not attended to in time. Too much grass or clover, given to a sow when her pigs are quite young, frequently causes this disease. It can generally be cheeked by shutting the sow up and feeding dry corn for a few days. Skimmed swcet milk fed the sow is also good. If pigs are large enongh to eat, give them dry, raw flour, or corn, ryc, or wheat, whole.

If too young to eat, a lump of Alum, the size of a walnut, may be dissolved in a quart of water, and a teaspoonful giren morning and erening, to pigs a week or so old.

Dr. Mnlford says, in the American Swine and Poultry Jomenal:

"Many of our swine breeders in the West sustain considerable loss annually by their pigs dying from the effects of what is commonly called scours, caused by the bad quality of the sow's 
milk. The disease is more apt to make its appearance when the sow has been fed upon dry corn or musty food. It generally attacks them within one or two days after their birth, and seldom after eight or ten clays. I have never failed to cure this disease by giving the sow as much Sulphur of the third decimal trituration as will statud on a nickel five-cent piece, once a day. It may be given in a little sweet milk, or upon a small piece of bread, and should be given one hour before feeding. The medicine can be procurcd of any Homœopathic physician. I have cured many cases with common sulphur, but prefer the above."

Mr. Joseph Harris, in his inraluable work on "The Pig," justly uses the following language:

"The most common complaints of little pigs are diarrhon and colds. The former is caused by griving the sow improper food, or a too sudden a change of diet, or by irregular feeding, or from want of pure witer and fresh air. WVe once lad a few cooked beans that were left in the steam-barrel until they decomposed. They were thrown on to the manure heap, and a sow, which was sucking pigs, ate some of them. Two datys afterwards, the whole litter was seized with violent diarrhœa, and one of them dicd in the course of two or three days. It was the worst case of the kind we ever had, and the diarrhea continued for four or five days, and was not stopped until we gave the pigs two or three drops of Landanum each, at niglit, in some fresh cream, with a teaspoon, and repeated the dose the next morning. This effected a cure, but the pigs did not regain their thrifty growtl for a week or ten days. We shonld add that the sow continued perfectly well, and manifested nn symptoms of the complaint. As a general rule, no medicine will be required. Change the fond of the mother, and let her go out into the air, but let the little pigs remain in the pen, and see that they are warm and comfortable. The less they are disturbed, and the more they sleep, the sooner will they recover. It is also very important to keep the pen clean and well ventilated. Nothing can be worse than to leave the evacuations in tue pen. Scatter some dry earth about the pen to absorb the offensive gases. Let the feeding apartment also be dusted over with dry earth, or soil of any kind that ean he obtained, and then scraped, and swept, and washed, and a little dry straw, or chiff, or sawdust, be spread on it, to prevent dampness. Scald the pig troughs with boiling water, and make them sweet and clean. Let this be done every day. T'se attendant should understand that the scours are an evi. dence of carel ssness or negligence." 


\section{CONSTIPATION.}

If swine are discorered voiding hard, dry dung in com. pact, ball-like masses, it denotes fever; they require a change to more loosening, cooling diet. Green and any kind of soft, easily digested food is good, and bran mashes prepared with hot water, or if possible, with flax-seed tea are excellent.

In obstinate cases, an ounce of Epsom Salts may be given, in an injection of warm soap suds.

There are few surer indications of something radically wrong in the swine-yard than continued constipation.

\section{EVERSION (TURNING OUT) OF THE RECTUM.}

Poorly kept and neglected pigs are liable to protrusion of the rectum, and it may be caused also by straining in parturition, (pig birth), constipation, and diarrhœa.

The protuduing part should be emptied, cleaned with warm water, moistened with Laudanum if at hand, gently returned and pushed up with the oiled finger a short distance, inside the anus. In treating this ailment, as well as most others, attention to diet and comfort is allimportant.

\section{RHEUMATISM.}

Sryptoxs. -Dullness, languor, or indisposition to more, followed by extreme lameness in one or more limbs, and heat, swelling, or tenderness of a joint, tendon, or group of muscles, the tenderness perhaps shifting from joint to joint.

Trentment. - A tablespoonful of Cod-liver Oil should be given to each pig once or twice a day in its food. A larger daily allowance than two tablespoonfuls to pigs three or four months old, while the oil is expensire, does not appear to hasten the cure in like ratio. The cod-liver oil, besides curing the rhenmatism, both acute and chronic, also improves the condition wonderfully. Provide well- 
'ittered, warm housing, from which the pigs can emerge to the yards at will. Give boiled or steamed food, and sour milk.

\section{PIGS LOSING THEIR TAILS.}

Pigs sometimes have their tails frozen, which causes them to drop off, but aside from this cause, it frequently results from an hereditary tendency to a disease of the skin which attacks the young pig at that particular point, the circulation is interfered with, and the member perishes and drops off.

If the disease appears, apply Carbolic Soap to the affected part, or wash clean, and apply Glycerine, Sweet Oil, or a little fresh Lard.

The most effectual preventive is to keep pigs clean, dry, and abundantly nourished.

\section{CANKER OR SORE MOUTH.}

Mr. S. M. Shepard, in his excellent book "The Hog in America," thinks this is usually the result of unhealthful milk from the sow or from poison on her teats obtained by contact with poisonous vines or wet grass. He says: "The first symptoms are lumps on the sow's udder, and sometimes sores; next will be noticed blisters on the lip, tongue and mouth of the pig; the tongue and lips become swollen and the roof and sides of the mouth inflamed and covered with deep red or white blister spots. Treatment: Catch the pig and swab its mouth out thoroughly with a solution of carbolic acid and water sufficiently strong to make the flesh upon the arm tingle. Apply with a rag or small piece of sponge tied on a stick. Strong sage tea applied in the same way is good, and in addition blow powdered sulphur through a straw into the pig's mouth. Bathe the sow's teats and udder with a weak solution of carbolic acid, and keep afflicted litters away from other pigs." 


\section{N D E X.}

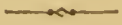

Atlen. A. B., Essay on Ferkshires to Am. Berkshire Association .... ti Artjohokes, Jerusalem or Brizilian $112-116$

Bston, kxport of ......... 11 Brlswin, Hom. Eluser, on Disestsenl swine $\therefore 40$ (i) P'asturage . . . . . . . . . 116

Berkshires ...............t2-it Allen, d. B., Essay ou ..... ti Berkshire Associstion .... 45 Characteristics and Markiugs ................ 46 ('russ with Essex ....... st Cross with Poland-China .. ti2 Earliest lmportations...... . 5is Heret Book ............ 45 Introluction into Warren Co.. Ohio ............... of

Record of .......... 224

Relative Merits, eompared with sutrolk and Fssex. sh-

Their food Qualities.... t4

"Windser Castle" ....... 51

lingham, K. l.., on Cookiner Fond. . . . .......

Boar, Castration of Olat....... 14

How to Cherose ......... St)

lupportance of Pure lired . 91

In-sud-in Breteline ....... (9:3

doint Bwhetship of ...... . 14

heeping . . . . . . tr.

Proper I ge of for Service - its

Fowles, Johin s., on How Clioleim

Rovulon, John, on sow Eatine here liges:

linziliau Artiobokes. .......... 11:2

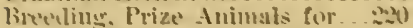

limeds-Iferviv mentioned and srnonsms: the other breeds in the reirular alphatedical orter:

bedforil.

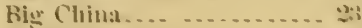

Butler County
Breeds-Brfield _.......... 28

Chester County 17 hites. .. . 34

Clinese ................. ts

Dick's Creek.............. 2l

Duraes .......... si

Great Westem..............

Giegory"s Creek.......... $\approx 1$

Irish Gimazier .......... . .

Jefrerson County (of N. Y.) 得

Jerser lieds.............. . .

Laneashires .............. . . .

Mngie ..................

Miami Valley ...........

Moore .................... 21

Poland................. . .

Polaud and China........ :1

Russia ..................

Shaker ..................

Simurese . . . . . . . . . . . . . . 49

Sutfolk, Berkshire, and Essex. C'ompared ....... s(l)-8i

Unim Villave..........

Warren (omutr........ Briggs, Miltou, eu Poland-Chinas $3:$

Ou How C'holera........ 2. 240

Brown. Charle's, on Poland amel

Poland-Chinas ........... …

Fryant, E. II.. on Coushl. . . . . 22t)

biurlington Huckeye on Irtichokes................... 115

Butchering II0gs........... 150

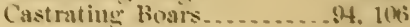

lidgling Hogs.......... 10:

Young Pirs............ 10.2

Cattle and swine, balue compared ..................... 14

Cattle, swiue ruming with ... . 1:2t

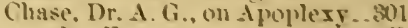

(1) Esse'x ... ...... (i)

(in Intlammation of the Brain .... $83(x)$

On Killney IV orms ........2.2.

(On lohamt-Chin:ls .....

Chemical ('ompusition of Arti-

cle's of Foud ................. 


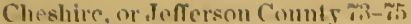
('mis, ('ol. F. D), (m) it National comvention's licpoit oll .. .. Simlers, .1. 11., m .... it Chester Whites a. . 3 i - id Charaderisties of ...... 42

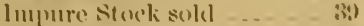
llirights of ... ... is Chichero, live-stock sales in kNi:

Clay, s. 11., Fisperimente ou conking find ........ . liil-1:1 llis Fond-nolier ...... 133 Clover, Vuluc as Foul .... 111 Compintive Value of Arlieles of lined . . . . . . 161

Conover, Thomas, on Polanel('hims

Coukine Fond for swine. 12\%-140 A piphratus for . . . 13\%-1.40 limglımm, li. l... on ...... lisio Clay, s. 11., lixperiments on $\ldots$. . .

Cookerel Moal ........... 18ז

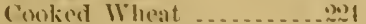

Hems, Prof., (111 ......... 1336; 11. M. \& W. I'. Nissom's Experiments on . . . . . 1:2!

Mane Anricultural Colleso Experimeute (un ...... Iiti Stalker, M., dixperiments (111 ..... 1:34-1:35

Stommed or lioileal Com _ 170

Stone. 11, 11., on .......... I31

Wilkinson, l'rof., on ...... . li31

Wool, Thomas, (1) ........ 1301

(ort)-ser Indian Corn.

Cottrell, H. W., lissity on the liclative Merits of the Sutfollis, Berkshires, mul lis-

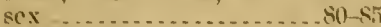

(1) Fissex ................ (iti ('uriug louk. Is it Probitable? Itil ('urtis, (o). F. D., on Cheshire or deffersum Commly ....... . it

Departmont of Agriculture, lnetheicuey of ................

Drtmers, Dr. 11. J., on "llog Cholera".................... 43 dieport om, to the Missouri state Bosmal of Aericultme

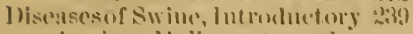
Anrima, Malionalt or lianmervens

Authax, Aproplentic .... 2.5il (arhumele .. - 250 Mouth, (imm, or (iloss. 151
Discases of Swine (mulinued).

Anthrax Diseasis _ _ _ 2.61

Conses of . _ ..... 2t4

Detmers, I)r. II. .I., on $24: 3$

Name proferable to Hog Cloblera.

P:เaren, 11x. N, II., on

The Contagion of . 2016

Apoplectic: Anflux -.. 20

Apoplexy ..........

Bladiler-irorm . ..........2.

Blind Stagerers..............

liull Nuse ............. . 29?

Brain, Intlammation of . . . 2us?

Canker or Sore Mouth . . . . .30\%

Cuturih, Nasil . . . . . . . . . . 399

Constipntion .............. 301

Commh ...................

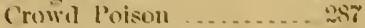

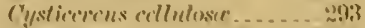

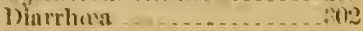

Epilepsy - .......

Epizonfic lntluenza of ș

nutoreacenrateNametham

"How Choler"i" ..... ...25.

('at arrhal - lỉhemแนat ic" Fotroll of ....... 25.

Conses of ........ 2(i.)

Cerplor-R li eu Fortu of ... 20:3

Dr. 11. d. lnetmers ou 2503

burntion of ........ 20 (i)

Gastrie - lihe umatic form of

1.ymphat ie - Rhemmatic torm of . . . . . . . . .

Preverition of . . . ?his

Treaturent of .........

Erysipelas, (iamerenous ... . . 47

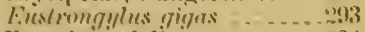

Eversion of lifetum _..... 01

Gameremous Eiysijedas.... 4 ti

llenvers ...... . . . . . . .

Hog ( 'holera. So-ealled : 241-28s

"1. II. W.," O(liı, 111. on ............

Anthrax Discases pro-

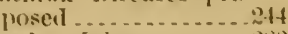

Bowles, Johm, ou ... 280

Brimgs', Milton, Remedy for .......... 25ti

Dr. H. J. Defmers on : $21 \%$

1)r. 11. I. Wetmers' lieport fo the Misson:ri B(1):21\%1

1)r. N. II. Patar(1) (m) $2 \pi 3$

"Infallilike liemedy," frour thes Leniseille Courite Junrual...... 
Diseases of Swine (continued).

Euizentie Influenza of Swive proposed as the Name..............5it

Kimberly, K., \& Sous. Treatment for ....... 255

Lonะ’s, J. \$., Experience with.............

Moore's, A. C., Treatment of ............... $: S 3$

Naune Ineorrect...... 443

Neglect of the Departunent of Agriculture . 24:?

Prof. James 1.aw cll .... is

Prof. T. R. Turner's Recipe for ...............

"Shart-weed" recommended as a Prevelltive

Stetson, Ezra, on ....... The Extent of its Ravages ................. $4 t 1$

The Missouri State Foard of Acriculture investigates anis

Inflamuation of Bruin . . . . . .999

ltch iu swine ... . . . . . . . 305

hilner W"orms..............

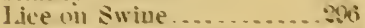

"Lights, hising of " ... . . .

Lungs, Inflammation of . . . .977

Malizuant Pustule ........... 201

Jlance of swine.......... 085

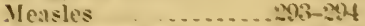

Na-al Catarrh ................

l'amalrsis of Loins........... 301

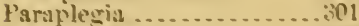

Pueumonia. ................ .

Quiusy.....................

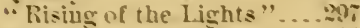

liectun. Turnimy out of . . .30)

Rheumatisu ..............

St. Anthomr s lire.........

Numoptes sivis...................

Sesb in Swine ...................

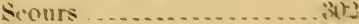

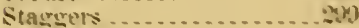

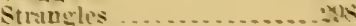

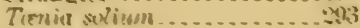

Tape-woru ...................

Thumus in swine .......... . .

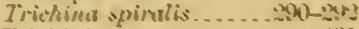

Trichiviosis

II hite Bristle ...............

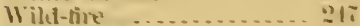

II (arm, Hlakler ...............

Wurn, Tayre.................

Wurms .................... the

Wo'ms, Kiluey .............t?
Dutrich, John G.. on How Cholera ................. 253 Ear Jutilatiou; Ear-Jlarks 214 Fssex . ... ...... 60-tis

Characteristics and Markings

Chase, Dr. of Kansas, on ... (i)

Cottrell, E. W. . on ..... tis

Crnssed with sutfolk ... .

Cross with kerkshire... \&

lielative Merits, compared with Berkshires and Suffolks ................ silks

Sidney on ............... it

Smith, William, m ...... if

Fxperiments, Prof. Henry's 193-30

Prof. Saubern's . . . . . . . . . . Shi

Fattening ............. 11:-1:7

By Hogsingetr Corn Fields 1 ñ̃

Cooked Food for...... 12:-1 40

Cooked ITheat for......... 160 s

Etfects of Cold in ........ 1st

Exclusive $(1$ se of Corn ..... 121

Greev Corv for .......... 1:20)

New and Ola Corn for.... 1:0)

New Enylaud Method... 125

On Raw Corn ........ 165-16i

Pumpkins for............ 1:4)

Salt and Condiments.... . 1:24

The Riglit Age for........ 1i:

With Fatteuiug Cattle .... 1:t

Feeting Floor ................ $46 b^{\circ}$

Feeding for Fat and Lean . 193-ich

Feeding in Sumuer....... 10र-11

Feed Cooker............ 137. 140

Foud, Artichokis as . ... . 11:-1it

Chemical Compusition of . 160

Comparative Value of .... 111

Cooking ............ 1:7-110

Feedine Value of as Comparel with Corn .. 161

Girass and Clover for... . 198

Fasture aud summer Foml (See Iudian ('orn) . . . 105-1 is

Faw Cora Feil in the Far lis

steamed or beiled corn l'ti

Vialue of l'eas......... 1:2 Ciestation, leriol of ...... nis-avi Grales with Common stock... . . Grass aud Clorer, Value of . 150-151 (iras, Hon. Alfred, ou Chester

$11{ }^{2}$ hites................... $t 1$ firowth, heports of hemark-

able ............ . . 219

Ilams, Curiug and Smoking 154-1.25

Harris, anseph, on Diarrhies : 013

Henry. Prof., on cinoting Fond liti

lleri-bionk of Berkshires...... ti

Berkishire, British............. 
Hog-Feeding and Pork Making. des. Sullivant on ...... 15ti-1s3 "Hogrging off " Com Fields : 211

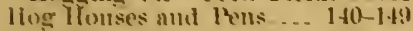
lloir P'ruthets, Ameriean, Distribution of ............. I:

kixported, Value .......... 11

Export in ten Years...... 13

llog linus, Tongs and Turners : 213 lines, (e)st per bue Hundreal Prounds gross.............. it Total Number l'ackesl .... 14 Weight of Packed ........ 13

Llolloway, Cephas, on PolandChinse .....................

llouses for swiue ......... 140-14? ('h:mles sinoads.......14t-140 For Breeting............ $1+1$ Kansas .............141-144 Large Objectionable .... It1

llow Much Pork in a bushel of Curn: $161-190$

Intian Corn and Pork, Reiatice

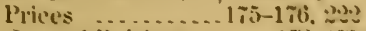
Cost of kaising ... .173-lo Experiments in Cooking

Fed in the Ear ....... 1(i)-167 Feeding New mal ohl 1.0 llow Winch Pork in a linshel of? 161

How Muel Pork (1) an Aere uf?

Not to be Fed Bardusirdy. 1:1 other Articles of bood ('oinpared with

Ste:med or Boiled..... 1\%

Jersey lieds ............. ritho

(haracteristies of ......

Terusalem Articholes . 11:-116

kimberly, R., it sou, (1) Hogr

("holers ............... L.aril

Expiort of

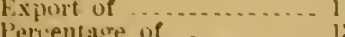

I.aril Oil Fixported in Eighteen le:trs

1.ates, J. B., Experiments in Feeding

law, l'rof. jaules, on ilog Chol(1):

On Intlammation of Brain su

(In Measles ............... 1.eldnt. Charles F., on Victorias 6 1.ong. J. S.. on Hour Cholera... 2ss Istiue Ar'l (o)lege, Experiment with cooked food 1:ib Maize-(See Indiau Corn).

Magie, D. M., on P'ulaud-Chioa a
Marking Ilogs .............. 214

Meal. Foeding Cooked ......... in liaw ....... llit

Medleines, Mode of Adminis-

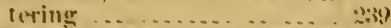

Messer, A., lieport of Unusual lirowth ............ _... 19

Mtiles, I'rof. M., Experiunents in Feeding ................. Ist Millikin, IIon John M., wn the "llogging of " of corn Fielals a: I On the Value of the Hog lroduct of the U. S..... It leport onthe Polududings it Millikin, Stephen, on Poland and Poland-china

Missouri State Boaral of Agrienlure hrestigation on $110 \mathrm{~g}$ Choleris ...............253

Monte, $A, C$ on Ferding Them 101

On ilog ('hulera..............

(m lice ... ...........

On Saring lonug Pigs ... yy

On the l'revention of Rooting .................... 213 On Thumps or lieares........ 2us M[ulfort. Dr., on Distrhera.... 30:! Nenpolitans ............. . Characteristie's and Marliings of .............. is Plhilltps, Dr. on .......... is IVell. Col. M. C.. on ..... New England Netlied of Fatleving ............ 1:5 P'asren, br, N. Il, on Hogr (holera

Un Kidney-11 orms

On Liee ..............

On Mange ..............

Pasture for Swine ....... 10s-11s Hon. E. Baldwin on ..... H Hi

Peas Vilue us Food ........ 11:

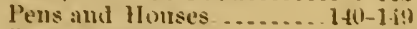
Pens, P'ortable ............. 1:17

l'ichle for Pork .............. lit

Pigr sul Pork, Cost of ..... :- 1

Pigrgeries.............. 141-141

l'ig-pens ............... 14t

l'igs, A. C. Monte on Raising . 101

Castrating Youmg .... 11:2

Feeting Youmer ...... lill

preventing from beiug ('rushed .... ....... . 49 Spryiug Yom Sows... 103 sinnmer Feading of ....... 109 The sow and her ....... 195 To l'rereat suw from Eating ............ 100, 214 Weauing -............ 10:3-105 
Points, Diagram of Seale of

Poland-China

Characteristics of

Comvention of swime Breeders, lieport on

Ilolloway, ('ephas, Aecomnt of .....................

Weights of ..................... 33

Pork l'ruluets, Exportation of, in $18 \%$. ................... 10

Price of, as Related to that of Indian Corn . . . . . . . . . 2.2.2

Pork, Cust of Raisiner........

Curing in Brine..........154

Danger of Eating Imperfeetlr Coolied........... 392

Dry-salting. . . . . . . . . 153

Export of .............. 11

How Much in a Bushel of Corn? .............1

llow Ilueh from au Aere of Corm? ..........

Is it l'rofitable to Cure ? . . ..217

Pickle for................15t

Relation of Prices of, to thost of Coru............2.2.

Portalule pig-peus........... 14

Prices of Pork and Corw, their

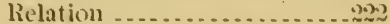

Prize Animals for Breeding .... 2.20

Pumplius for Feeding ....... 1:0

Quarrelsome and Ficrhtiug llogs:216

Reeord, Aneriean Berkshire... 2.24

Chester White............2:06

Duroe-t Tersey . . . . . . . . . . . . . .

Polant-china .............. 20.

American ...............25

('entral ...............25

Northwestern ..........

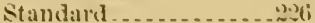

Records aud Recordiug ........2.23

Relative Merits of suffolks,

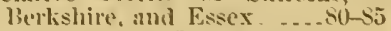

Reprort of the Dejartment of Aqriculture on sows Eating

l'ius .... .................

Repurts of liemarkahle firnwth. 219

Riclerliner llogs, To Castrate. . . 10\%

Rinering l Iogrs... .............213

Ruting, ils Prevention . . . . . ...213

Salt for swime ... . . . . . 1:1

Samblers, d. II.. on Cheshires... 74

scallims, Apparatus for _... Jis

Scesle of loints for Judging swine ... . ..... . . .

Sloulaters, Curing and simoking

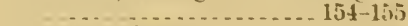

Siluey ou Essex............... bt.
Sisson, H. M. \& W. P., on Cocking lood................. ling Slatightering, Curing, and l'reserving Fork. .......... 14!1-1is6 Small Yorkshires............. (il Sulth, Willium, on Essex...... (it

on sutrolks . . . . . . . . . . . 59

Smoking Meats................ $15 j$

Snoad, Churles, llowse fur Swine

So ........................ 14t-14t

Sow, at IV caning ............ 105

Condition of, for Breeling 216

Feed for, at farrowine Time ! 00

Feeding while with Pig.... is

How to Choose........... 9is

Pen for, and Nest........... 99

Periol of Gestation in . .... . as

Spaying ...................10

Time to Breed............ 90

To l'rerent from Eating her'

Pigs ............99-100, 214

When in leat ..........

Spaying Sow-pigs ............ 103

Sows _............ 10\%

Stallier, Mr., on Coolied Food 1:34-1:25

Stetsou, Ezra, on Hog Cholera : 28 \%

Sties..................141-14i

Steck Journat, on Feeding Fluor

and Pen................. 146

Stock Yards Receipts........... 2it

Stuw, N. II., on Cuoked Fuod 131

Suffullis .................5t-6i

Cross with Essex ........ Sis

Charneteristies and Markings of ........... (i)

Relative Merits Compared with berkshire and Es-

sex ...........

Report of Comventiou $\mathrm{cu}$. . 60

Smith, William, on ....... 5y

Weutwortl, llon. J., on ... 56

Sullirant. Joseph, Essay ou llog

Feeding and Pork dlaking $156-183$ Summer Food........... 10 s-1 is

Sreet Corru for Swine . . . . . 1: 1:0

su ime, Clas-ifying and Juclyiug at Fairs ................

Distribution of 11 orhl'ssupply ................. 10

Export of Lire.......... 11

Nimmber of, Gradual Growth in U. S. ............. 10

Paclied in Twelre Mouths. . 10

(Wiarrelsome ............. 16

scinle of l'oints for Judging and

Their lalue as Compared

with Cittle .......... 15

The Number of, in the U. S. 9

White, Disappearauce of. . 20? 
Turner, Prof. J. B., on Hog Cholera ................282-283

Victorias

Characteristics and Markings of .............. 76

Leland, Charles E., on . . . . 76

Weaning Pigs............ 103-105

Weights, Important Contrasts _ 201

Wela, Col. M. C., on Neapolitans

Wentworth, Hon. Jolu, on Suffolk8.
Wheat, Feeding Cooked.......221

Wilkinson, Prof., on Cooking

Food _........................ 131

Williams, A. C., on Artichokes 11\%

Wood, Thomas, on Chester

Whites

on Cooked Food.........130

on the Profit of Curing Pork 217

Yorkshires

Report of National Convention on ............... 69

Small.......................... 61 



\section{STANDARD BOOKS}

PUBLISHED BY

ORANGE JUDD COMPANY

NEW YORK

AsHiland Building

315-321 Fourth Avenue
CHICAGO

People's Gas Building 150 Michigan Avenue

Any of these books will be sent by mail, postpaid, to any part of the world, on receipt of catalog price. We are always happy to correspond with our patrons, and cordially invite them to address us on any matter pertaining to rural books. Send for our large illustrated catalog, free on application.

\section{First Principles of Soil Fertility}

By Alfred Vivian. There is no subject of more vital importance to the farmer than that of the best method of maintaining the fertility of the soil. The very evident decrease in the fertility of those soils which have been under cultivation for a number of years, combined with the increased competition and the advanced price of labor, have convinced the intelligent farmer that the agriculture of the future must be based upon more rational practices than those which have been followed in the past. We have felt for some time that there was a place for a brief, and at the same time comprehensive, treatise on this important subject of Soil Fertility. Professor Vivian's experience as a teacher in the short winter courses has admirably fitted him to present this matter in a popular style. In this little book he has given the gist of the subject in plain language, practically devoid of technical and scientific terms. It is pre-eminently a "First Book," and will be found especially valzable to those who desire an introduction to the subject, and who intend to do subsequent reading. Illustrated. $5 \times 7$ inches. 265 pages. Cloth. Net, $\$ 1.00$

\section{The Study of Corn}

By Prof. V. M. Shoesmith. A most helpful book to all farmers and students interested in the selection and improvement of corn. It is profusely illustrated from photographs, all of which carry their own story and contribute their part in making pictures and text matter a clear, concise and interesting study of corn. Illustrated. $5 \times 7$ inches. I00 page6. Cloth. . . . . . ... Net, \$0.50 


\section{The Management and Feeding of Cattle}

By Prof. Thomas Shaw. The place for this book will be at once apparent when it is stated that it is the first book that has ever been written which discusses the management and feeding of cattle, from the birth of the calf until it has fulfilled its mission in life, whether on the block or at the pail. The book is handsomely printed on tine paper, from large, clear type. Fully illustrated. 51/2x8 incles. 496 pages. Cloth. . . . . . Net, $\$ 2.00$

\section{The Farmer's Veterinarian}

By Cilarlfs IVillam Burkett. This book abounds in halpful suggestions and valuable information for the most successful treatment of ills and accidents, and disease troubles. A practical treatise on the diseases of farm stock; containing brief and popular advice on the nature, cause and treatment of disease, the common ailments and the care and management of stock when sick. It is profusely illustrated, containing a number of halftone illustrations, and a great many drawings picturing diseases, their symptoms and familiar attitudes assumed by farm animals when affected with disease, and presents, for the first time, a plain, practical and satisfactory guide for farmers who are interested in the common diseases of the farm. Illustrated. $5 \times 7$ inches. $2 S S$ pages. Cloth. Net, \$r.50.

\section{First Lessons in Dairying}

By Hubert E. VAx Norman. This splendid little book has been written from a practical point of view, to fill a place in dairy literature long needed. It is designed primarily as a practical guide to successful dairying, an elementary text-book for colleges and for use especially in short-course classes. It embodies underlying principle: involved in the handling of milk, delivery to factory, ship. ping station, and the manufacture of butter on the farm. It is written in a simple, popular way, being free from technical terms, and is easily understood by the average farm boy. The book is just the thing for the every-day dairyman, and should be in the hands of every farmer in the country. Illustrated. $5 \times 7$ inches. I00 pages. Cloth. Net, $\$ 0.50$.

\section{A Dairy Laboratory Guide}

By H. E. Ross. While the book is intended primarily for use in the laboratory, it should be of value to the practical dairyman. The time has come when the successful dairyman must study his business from a purely scientific point of view, and in this book the scientific principles, upon which dairy industry is based, are stated clearly and simply, and wherever it is possible, these principles are illustrated by practical problems and examples. 90 pages. $5 \times 7$ inches. Cloth. 


\section{Profitable Stock Raising}

By Clarence A. Siramel. This book covers fully the principles of breeding and feeding for both fat stock and dairying type. It tells of sheep and mutton raising, hot kouse lambs, the swine inclustry and the loorse nuarket. Finally, he tells of the preparation of stock for the market and how to prepare it so that it will bring a high market price. Live stock is the most important feature of farm life, and statistics show a production far short of the actual requirements. There are many problems to be faced in the profitable production of stock, and these are fully and comprehensively covered in Mr. Shamel's new book. Illustrated. 5x7 inches, 288 pages. Cloth. Net, \$I.50

\section{The Business of Dairying}

By C. B. LANE. The anthor of this practical little book is to be congratulated on the successful manner in which he has treated so important a subject. It has been prepared for the use of dairy students, producers and handlers of milk, and all who make dairying a business. Its purpose is to present in a clear and concise manner various business methods and systems which will help the dairyman to reap greater profits. This book meets the needs of the average dairy farmer, and if carefully followed will lead to successful dairying. It may also be used as an elementary textbook for colleges, and especially in shortcourse classes. Illustrated. $5 \times 7$ inches. 300 pages. Cloth. Net, \$1.25

\section{Questions and Answers on Buttermaking}

By Ciras A. Publow. This book is entirely different from the usual type of dairy books, and is undoubtedly in a class by itself. The entire subject of butter-making in all its branches has been most thoroughly treated, and many new and important features have been added. The tests for moisture, salt and acid have received special attention, as have also the questions on cream separation, pasteurization, commercial starters, cream ripening, cream overrun, marketing of butter, and creamery management. Illustrated. $5 \times 7$ inches. 100 pages. Cloth. Net, $\$ 0.50$

\section{Questions and Answers on Milk and Milk Testing}

By Chas. A. Publow, and Hugh C. Troy. A book that no student in the dairy industry can afford to be without. No other treatise of its kind is available, and no book of its size gives so much practical and useful information in the study of milk and milk products. Illustrated. $5 \times 7$ inches. 100 pages. Cloth. . .... Net, \$0.50 
By Charles William Burkett, Director Kansas Agricultural Experiment Station. The most complete and popular work of the kind ever published. As a rule, a book of this sort is dry and uninteresting, but in this case it reads like a novel. The author has put into it his individuality. The story of the properties of the soils, their improvement and management, as well as a discussion of the problems of crop growing and crop feeding, make this book equally valuable to the farmer, student and teacher. Illustrated. 303 pages. $51 / 2 \times 8$ inches. Cloth. . Net, \$1.25

\section{Weeds of the Farm Garden}

By L. H. PAMMEL. The enormous losses, amounting to several hundred million dollars annually in the United States, caused by weeds stimulate us to adopt a better system of agriculture. The weed question is, therefore a most important and vital one for American farmers This treatise will enable the farmer to treat his field to remove weeds. The book is profusely illustrated by photographs and drawings made expressly for this work, and will prove invaluable to every farmer, land owner, gardener and park superintendent. $5 \times 7$ inches. 300 pages. Cloth. . . . . . . . . . . Net, \$1.50

\section{Farm Machinery and Farm Motors}

By J. B. Davidson and L. W. Chase. Farm Machinery and Farm Motors is the first American book published on the subject of Farm Machinery since that written by J. J. Thomas in 1867. This was before the development of many of the more important farm machines, and the general application of power to the work of the farm. Modern farm machinery is indispensable in present-day farming operations, and a practical book like Farm Machinery and Farm Motors will fill a much-felt need. The book has been written from lectures used by the authors before their classes for several years, and which were prepared from practical experience and a thorough review of the literature pertaining to the subject. Although written Iprimarily as a text-book, it is equally useful for the practical farmer. Profusely illustrated. $5 \frac{1}{2} \times 8$ inches. 520 pages. Cloth. .......... . Net, $\$ 2.00$

\section{The Book of Wheat}

By P. T. Dondlinger. This book comprises a complete study of everything pertaining to wheat. It is the work of a student of economic as well as agricultural conditions, well fitted by the broad experience in both practical and theoretical lines to tell the whole story in a condensed form. It is designed for the farmer, the teacher, and the student as well. Illustrated. $5 \mathrm{~T} / 2 \times 8$ inches. 370 pages. Cloth. 


\section{The Cereals in America}

By Thomas F. Hunt, M.S., D.Agri., Professor of Agronomy, Cornell University. If you raise five acres of any kind of grain you cannot afford to be without this book. It is in every way the best book on the subject that has ever been written. It treats of the cultivation and improvement of every grain crop raised in America in a thoroughly practical and accurate manner. The subject-matter includes a comprehensive and succinct treatise of wheat, maize, oats, barley, rye, rice, sorghum (kafir corn) and buckwheat, as related particularly to American conditions. First-hand knowledge has been the policy of the author in his work, and every crop treated is presented in the light of individual study of the plant. If you have this book you have the latest and best that has been written upon the subject. Illustrated. 450 pages. $51 / 2 \times 8$ inches. Cloth. . . . . . . . . . . $\$ 1.75$

\section{The Forage and Fiber Crops in America}

By Thomas F. Hunt. This book is exactly what its title indicates. It is indispensable to the farmer, student and teacher who wishes all the latest and most important information on the subject of forage and fiber crops. Like its famous companion, "The Cereals in America," by the same author, it treats of the cultivation and improvement of every one of the forage and fiber crops. With this book in hand, you have the latest and most up-to-date information available. Illustrated. 428 pages. $5 \frac{1}{2} \times 8$ inches. Cloth. . . . $\$ 1.75$

\section{The Book of Alfalfa}

History, Cultivation and Merits. - Its Uses as a Forage and Fertilizer. The appearance of the Hon. F. D. CoBurn's little book on Alfalfa a few years ago has been a profit revelation to thousands of farmers throughout the country, and the increasing demand for still more information on the subject has induced the author to prepare the present volume, which is by far the most authoritative, complete and valuable work on this forage crop published anywhere. It is printed on fine paper and illustrated with many full-page photographs that were taken with the especial view of their relation to the text. 336 pages. $6^{1 / 2} \times 9$ inches. Bound in cloth, with gold stamping. It is unquestionably the handsomest agricultural reference book that has ever been issued. Price, postpaid, . \$2.00

\section{Clean Milk}

By S. D. BelChER, M.D. In this book the author sets forth practical methods for the exclusion of bacteria from milk, and how to prevent contamination of milk from the stable to the consumer. Illustrated. $5 \times 7$ inches. 146 pages. Cloth. . . . . , . . : . . . \$1.00 


\section{Bean Culture}

By Glenn C. Sevey, B.S. A practical treatise on the pro. duction and marketing of beans. It includes the manner of growth, soils and fertilizers adapted, best varieties, seed selection and breeding, planting, harvesting, insects and fungous pests, composition and feeding value; with a special chapter on markets by Albert W. Fulton. A practical book for the grower and student alike. Illustrated. 144 pages. $5 \times 7$ inches. Clotl. . . . . . . . . . . \$0.50

\section{Celery Culture}

By W. R. Bentrie. A practical guide for beginners and a standard reference of great interest to persons already engaged in celery growing. It contains many illustrations giving a clear conception of the practical side of celery culture. The work is complete in every detail, from sowing a few sceds-in a window-box in the house for early plants, to the handling and marketing of celery in carload lots. Fully illustrated. I50 pages. $5 \times 7$ inches. Cloth. . . . . . \$0.50

\section{Tomato Culture}

By WILl IV. Tracy. The author has rounded up in this book the most complete account of tomato culture in all its phases that has ever been gotten togetier. It is no secons hand work of reference, but a complete story of the practic, experiences of the best-posted expert on tomatoes in the world. No gardener or farmer can afford to be without the book. Whether grown for home use or commercial purposes, the reader has here suggestions and information nowhere else available. Illustrated. I 50 pages, $5 \times 7$ inches. Cloth. $\$ 0.50$

\section{The Potato}

By SaMuel Fraser. This book is destined to rank as a standard work upon Potato Culture. While the practical side has been emphasized, the scientific part has not been neglected, and the information given is of value, both to the grower and to the student. Taken all in all, it is the most complete, reliable and authoritative book on the potato ever published in America. Illustrated. 200 pages. $5 \times 7$ inches. Cloth. . \$0.75

\section{Dwarf Fruit Trees}

By F. A. Waugr. This interesting book describes in detail the several varieties of dwarf fruit trees, their propagation. planting, pruning, care and general management. Where there is a limited amount of ground to be devoted to orchard purposes, and where quick results are desired, this book will meet with a warm welcome. Illustrated. II 2 pages. $5 \times 7$ inches. Cloth. . . . . . . . . . \$0.50 




LIBRARY OF CONGRESS

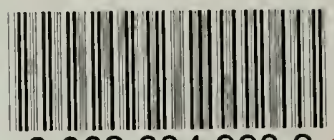

00028349932 